\title{
Evaluation of Dredged Material \\ Proposed for Ocean Disposal \\ from Bronx River Project Area, \\ New York
}

B. D. Gruendell

W. W. Gardiner

L. D. Antrim

M. R. Pinza

E. S. Barrows

A. B. Borde
RECEIVED

JAN 07997

OSTI

Battelle Marine Sciences Laboratory

Sequim, Washington

December 1996

Prepared for the

U.S. Army Corps of Engineers - New York District under a Related Services Agreement

with the U.S. Department of Energy

under Contract DE-AC06-76RLO 1830

Pacific Northwest National Laboratory

Operated for the U.S. Department of Energy

by Battelle Memorial Institute

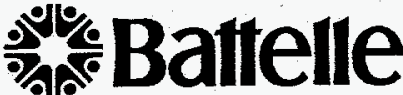




\title{
DISCLAIMER
}

This report was prepared as an account of work sponsored by an agency of the United States Government. Neither the United States Government nor any agency thereof, nor Battelle Memorial Institute, nor any of their employees, makes any warranty, express or implied, or assumes any legal liability or responsibility for the accuracy, completeness, or usefulness of any information, apparatus, product, or process disclosed, or represents that its use would not infringe privately owned rights. Reference herein to any specific commercial product, process, or service by

trade name, trademark, manufacturer, or otherwise does not necessarily constitute or imply its endorsement, recommendation, or favoring by the United States Government or any agency thereof, or Battelle Memorial Institute. The views and opinions of authors expressed herein do not necessarily state or reflect those of the United States Government or any agency thereof.

\author{
PACIFIC NORTHWEST NATIONAL LABORATORY \\ operated by \\ BATTELLE MEMORIAL INSTITUTE \\ for the \\ UNITED STATES DEPARTMENT OF ENERGY \\ under Contract DE-AC06-76RLO 1830
}

Printed in the United States of America

Available to DOE and DOE contractors from the

Office of Scientific and Technical Information, P.O. Box 62, Oak Ridge, TN 37831;

prices available from (615) 576-8401.

Available to the public from the National Technical Information Service, U.S. Department of Commerce, 5285 Port Royal Rd., Springfield, VA 22161 
EVALUATION OF DREDGED MATERIAL PROPOSED FOR OCEAN DISPOSAL FROM BRONX RIVER PROJECT AREA, NEW YORK

B. D. Gruendell

W. W. Gardiner

L. D. Antrim

M. R. Pinza

E. S. Barrows

A. B. Borde

Battelle Marine Sciences Laboratory

Sequim, Washington

December 1996

Prepared for the

U.S. Army Corps of Engineers - New York District under a Related Services Agreement

with the U.S. Department of Energy

under Contract DE-AC06-76RLO 1830

Pacific Northwest National Laboratory

Richland, Washington 99352 
D<smiles>C1CCC1</smiles>

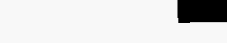




\section{DISCLAIMER}

Portions of this document may be illegible in electronic image products. Images are produced from the best available original document. 


\section{Summary}

The objective of the Bronx River project was to evaluate proposed dredged material from the Bronx River project area in Bronx, New York, to determine its suitability for unconfined ocean disposal at the Mud Dump Site. Bronx River was one of five waterways that the U.S. Army Corps of Engineers-New York District (USACE-NYD) requested the Battelle Marine Sciences Laboratory (MSL) to sample and to evaluate for dredging and disposal in May 1995. Sediment samples were collected from the Bronx River Project area, as well as from Shark River, New Jersey; Shoal Harbor/Compton Creek, New Jersey; Cheesequake Creek, New Jersey; and Westchester Creek, New York. Combining sample collection and concurrent evaluation of multiple dredged material projects was more cost-effective for the USACE-NYD because the expenses of sediment sampling, reference site testing, and quality control analyses could be shared among projects.

Tests and analyses were conducted according to the manual developed by the USACE and the U.S. Environmental Protection Agency (EPA), Evaluation of Dredged Material Proposed for Ocean Disposal (Testing Manual), commonly referred to as the "Green Book," and the regional manual developed by the USACE-NYD and EPA Region II, Guidance for Performing Tests on Dredged Material to be Disposed of in Ocean Waters.

The evaluation of proposed dredged material from the Bronx River project area consisted of bulk sediment physical and chemical analyses, chemical analyses of dredging site water and elutriate, benthic and water-column acute toxicity tests, and bioaccumulation studies. Fifteen individual sediment core samples collected from the Bronx River project area were analyzed for grain size, moisture content, and total organic carbon (TOC). One composite sediment sample, representing the entire reach of the area proposed for dredging, was analyzed for bulk density, specific gravity, metals, chlorinated pesticides, polychlorinated biphenyl (PCB) congeners, polynuclear aromatic hydrocarbons (PAH), and 1,4dichlorobenzene. Dredging site water and elutriate water, which was prepared from the suspended-particulate phase (SPP) of the Bronx River sediment composite, were analyzed for metals, pesticides, and PCBs. Benthic acute toxicity tests were performed with the amphipod Ampelisca abdita and the mysid Mysidopsis bahia. The amphipod and mysid benthic toxicity 
test procedures followed EPA guidance for reduction of total ammonia concentrations in test systems prior to test initiation. Water-column or SPP toxicity tests were performed with three species, the mysid Mysidopsis bahia, the juvenile silverside Menidia beryllina, and larvae of the mussel Mytilus galloprovincialis. Bioaccumulation tests were conducted with the burrowing, deposit-feeding polychaete worm Nereis virens and the surface-detrital-feeding, bent-nose clam, Macoma nasuta.

Bronx River sediment core samples were generally black, silty-clay material. Two of the 15 stations were predominantly sand and gravel. The Bronx River sediment composite sample contained eminent levels of metals, pesticides (particularly the DDD/DDE/DDT group of compounds), PCBs, PAHs, and 1,4-dichlorobenzene.

Statistically significant acute toxicity was found in the Bronx River composite in the A. abdita test, but not in the $M$. bahia test. Statistically significant acute toxicity and a greater than $20 \%$ increase in mortality over the reference sediment was found in the static-renewal tests with $A$. abdita, but greater than $10 \%$ increase in mortality over reference sediment was not found in the static tests with $M$. bahia. In water-column toxicity tests, acute toxicity was demonstrated with the Bronx River composite by $M$. beryllina, $M$. bahia, and $M$. galloprovincialis, which exhibited median lethal concentrations $\left(\mathrm{LC}_{50}\right)$ of $21.5 \% \mathrm{SPP}, 71.6 \%$ SPP, and $>100 \%$ SPP, respectively. The median effective concentration $\left(E C_{50}\right)$ for M. galloprovincialis normal development, a more sensitive measure than survival, was $23.6 \%$ SPP for the composite.

Following 28-day bioaccumulation tests, concentrations of some contaminants were elevated in $M$. nasuta and $N$. virens tissues relative to levels in organisms exposed to the Mud Dump Reference Site. Concentrations of all metals were higher in $M$. nasuta than in $N$. virens. Pesticide and PCB concentrations were generally higher in $N$. virens than in $M$. nasuta. Concentrations of PAHs were higher in $M$. nasuta than in $N$. virens, many compounds by factors of 2 to 10 times. Many tissue burdens of organisms exposed to Bronx River sediment were statistically significantly higher for pesticides, PCBs, and PAHs, relative to those of the Mud Dump Reference Site.

Tissues of both species exposed to the Bronx River sediment composite had wet weight tissue body burdens that were lower than the U.S. Food and Drug Administration (FDA) action levels for poisonous or deleterious substances in fish and shellfish for human consumption for selected pesticides. Tissue concentrations were also below the FDA levels of concern for 
chronic shellfish consumption for metals, except for $M$. nasuta, which had levels of lead slightly higher than the FDA levels of concern. Tissue concentrations were below all the designated USACE-NYD bioaccumulation matrix values. 


\section{Contents}

Summary $\ldots \ldots \ldots \ldots \ldots \ldots \ldots \ldots \ldots \ldots \ldots \ldots \ldots \ldots \ldots \ldots \ldots \ldots \ldots \ldots \ldots \ldots \ldots \ldots i i$

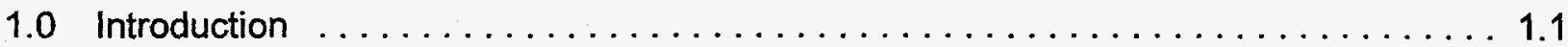

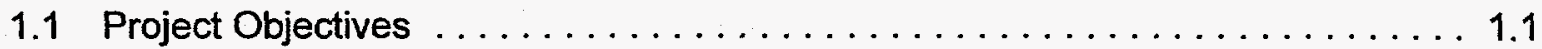

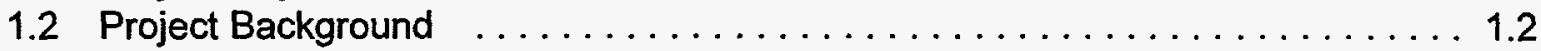

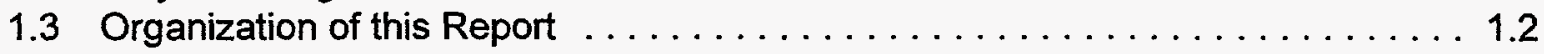

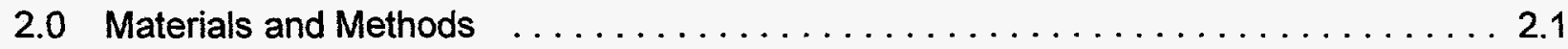

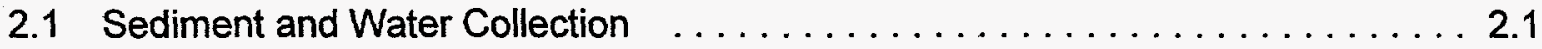

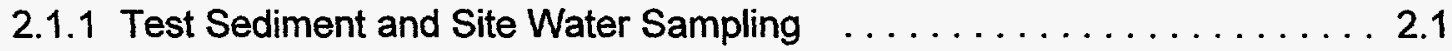

2.1.2 Reference and Control Sediment Sampling $\ldots \ldots \ldots \ldots \ldots \ldots \ldots . .3$

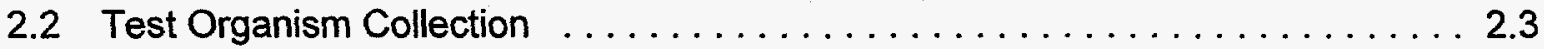

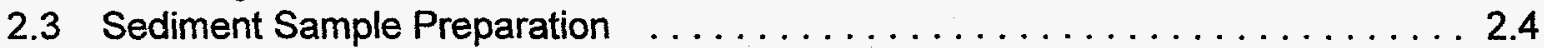

2.3.1 Laboratory Preparation and Safety Considerations . . . . . . . . 2.5

2.3.2 Preparation of Sediment for Benthic Testing and Bulk Sediment Analyses . . . . . . . . . . . . . . . . . . 2.6

2.3.3 Preparation of Suspended-Particulate Phase and Elutriate $\ldots \ldots \ldots \ldots 2.7$

2.4 Physical and Chemical Analytical Procedures $\ldots \ldots \ldots \ldots \ldots \ldots \ldots$

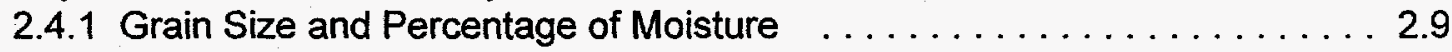

2.4 .2 Bulk Density and Specific Gravity $\ldots \ldots \ldots \ldots \ldots \ldots \ldots \ldots \ldots \ldots$

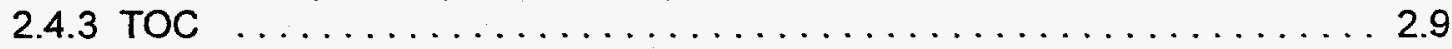

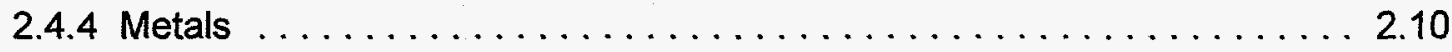

2.4.5 Chlorinated Pesticides and PCBs $\ldots \ldots \ldots \ldots \ldots \ldots \ldots \ldots \ldots \ldots \ldots \ldots \ldots \ldots \ldots .14$

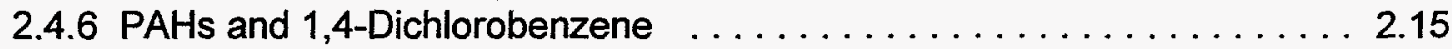

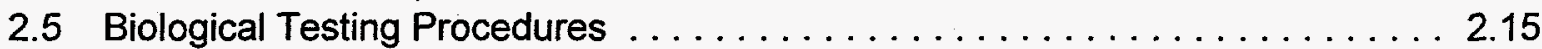

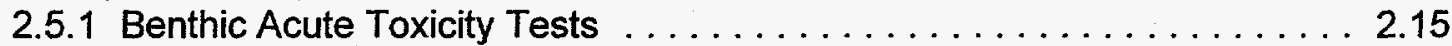

2.5.2 Water-Column Toxicity Tests ... . . . . . . . . . . . . . 2.20

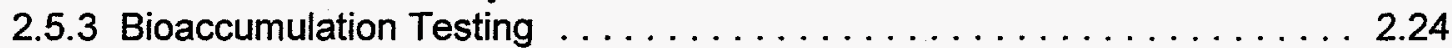

2.6 Data Analysis and Interpretation Procedures $\ldots \ldots \ldots \ldots \ldots \ldots \ldots \ldots \ldots$

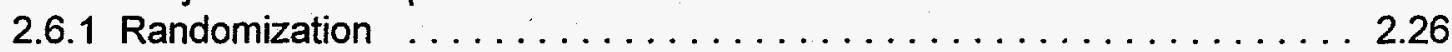

2.6.2 Statistical Analysis of Water-Column Tests . . . . . . . . . . . 2.26

2.6.3 Statistical Analysis of Benthic Toxicity Tests . . . . . . . . . . . 2.27

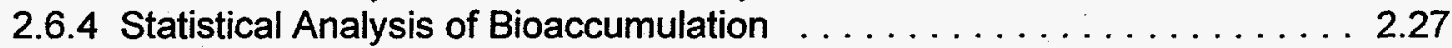

2.7 Quality Assurance/Quality Control Procedures . . . . . . . . . . . 2.28

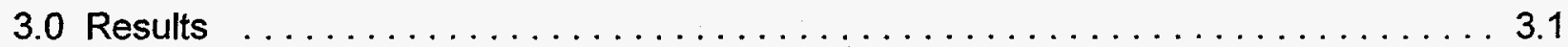

3.1 Sample Collection and Processing $\ldots \ldots \ldots \ldots \ldots \ldots \ldots \ldots \ldots \ldots \ldots \ldots \ldots$

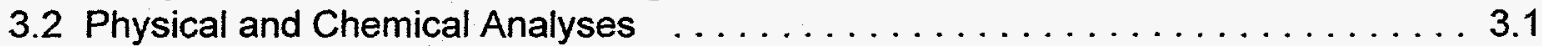

3.2.1 Sediment Core Sample Description $\ldots \ldots \ldots \ldots \ldots \ldots \ldots \ldots \ldots \ldots \ldots$

3.2.2 Grain Size, Percentage of Moisture, Bulk Density, Specific Gravity, and Total Organic Carbon ... . . . . . . . . . . . . . . . . 3.1

3.2 .3 Metals . . . . . . . . . . . . . . . . . . . . . . . . 3.4

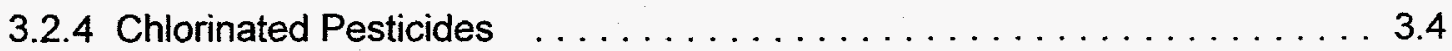

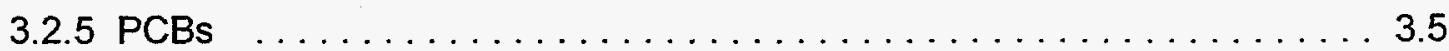

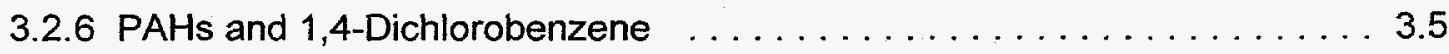




\section{Contents (contd)}

3.3 Site Water and Elutriate Analyses $\ldots \ldots \ldots \ldots \ldots \ldots \ldots \ldots \ldots \ldots \ldots$

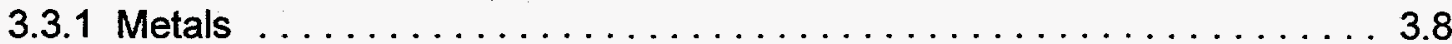

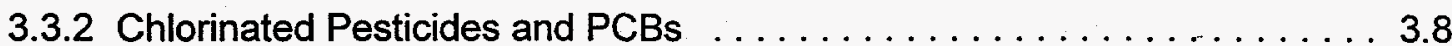

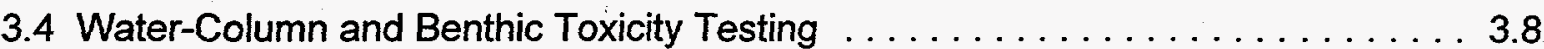

3.4.1 Ampelisca abdita Benthic Acute Toxicity Test . . . . . . . . . . . . . 3.10

3.4.2 Mysidopsis bahia Benthic Acute Toxicity Test . . . . . . . . . . . 3.10

3.4.3 Menidia beryllina Water-Column Toxicity Test . . . . . . . . . . 3.11

3.4.4 Mysidopsis bahia Water-Column Toxicity Test . . . . . . . . . . . 3.12

3.4.5 Mytilus galloprovincialis Water-Column Toxicity Test . . . . . . . . . . 3.13

3.5 Bioaccumulation Tests with Macoma nasuta and Nereis virens . . . . . . . 3.13

3.5.1 Bioaccumulation of Metals in Macoma nasuta . . . . . . . . . . . . . . 3.14

3.5.2 Bioaccumulation of Chlorinated Pesticides in Macoma nasuta . . . . . . 3.14

3.5.3 Bioaccumulation of PCBs in Macoma nasuta . . . . . . . . . . . . . 3.14

3.5.4 Bioaccumulation of PAHs and 1,4-Dichlorobenzene in Macoma nasuta . 3.17

3.5.5 Bioaccumulation of Metals in Nereis virens . . . . . . . . . . . . . . . . 3.17

3.5.6 Bioaccumulation of Chlorinated Pesticides in Nereis virens . . . . . . 3.17

3.5.7 Bioaccumulation of PCBs in Nereis virens . . . . . . . . . . . . 3.20

3.5.8 Bioaccumulation of PAHs and 1,4-Dichlorobenzene in Nereis virens . . 3.20

3.5.9 Magnification factors of compounds in Macoma nasuta and

Nereis virens . . . . . . . . . . . . . . . . . 3.23

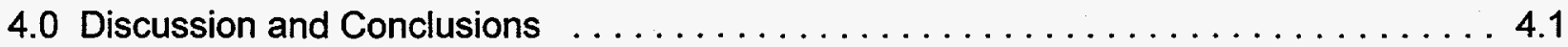

4.1 Sediment Physical and Chemical Characterization $\ldots \ldots \ldots \ldots \ldots \ldots \ldots \ldots .2$

4.2 Site Water and Elutriate Chemical Characterization $\ldots \ldots \ldots \ldots \ldots \ldots \ldots .2$

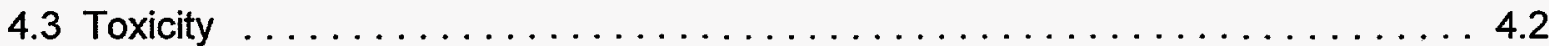

4.4 Bioaccumulation $\ldots \ldots \ldots \ldots \ldots \ldots \ldots \ldots \ldots \ldots \ldots \ldots \ldots \ldots \ldots \ldots$

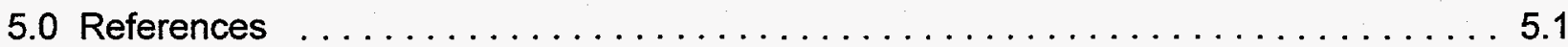

Appendix A. Sediment Physical/Chemical Analyses and Quality Assurance/Quality

Control Data for the Bronx River Project $\ldots \ldots \ldots \ldots \ldots \ldots \ldots \ldots \ldots$.1

Appendix B. Site Water and Elutriate Chemical Analyses and Quality Assurance/Quality Control Data, Bronx River Project ...................

Appendix C. Benthic Acute Toxicity Test Data, Bronx River Project $\ldots \ldots \ldots \ldots$. . . .1

Appendix D. Water-Column Toxicity Test Data, Bronx River Project $\ldots \ldots \ldots \ldots$. . . .

Appendix E. Bioaccumulation Test Data, Bronx River Project . . . . . . . . . . . E.1

Appendix F. Macoma nasuta Tissues Chemical Analyses and Quality Assurance/Quality Control Data, Bronx River Project ..................... F.1

Appendix G. Nereis virens Tissues Chemical Analyses and Quality Assurance/Quality Control Data for Bronx River Project 


\section{Contents (contd)}

\section{Figures}

FIGURE 1.1 Location of Bronx River Project Area and Sample Collection Stations . . . 1.3

FIGURE 2.1. Testing Containers for Benthic Static Renewal Toxicity Tests $\ldots \ldots \ldots 2.17$

FIGURE 4.1. Summary Matrix of Bronx River Sediment Toxicity and Bioaccumulation in Comparison with the Mud Dump Reference Site . . . . . . . . . . 4.6

\section{Tables}

TABLE 2.1. List of Analytes, Methods, and Target Detection Limits . . . . . . . . . . 2.11

TABLE 3.1 Summary of Sediment Sample Data for Bronx River Project Area $\ldots \ldots . .3 .2$

TABLE 3.2 Bronx River Sediment Core Descriptions $\ldots \ldots \ldots \ldots \ldots \ldots \ldots . \ldots$

TABLE 3.3 Results of Analysis of Bronx River Sediment Samples for Grain Size, Percentage of Moisture, and Total Organic Carbon . . . . . . . . 3.4

TABLE 3.4 Results of Analysis of Bronx River Sediment Samples for Metals . . . . . . 3.5

TABLE 3.5 Results of Analysis of Bronx River Sediment for Chlorinated Pesticides and

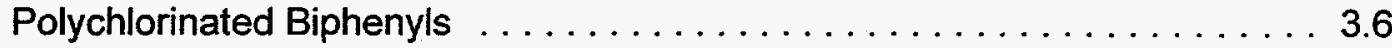

TABLE 3.6 Results of Analysis of Bronx River Sediment for PAHs and 1,4 Dichlorobenzene ................... 3.7

TABLE 3.7 Results of Analysis of Bronx River Site Water and Elutriate for Metals _ . 3.8

TABLE 3.8 Results of Analysis of Bronx River Site Water and Elutriate for Chlorinated

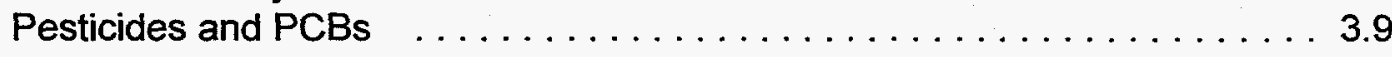

TABLE 3.9 Summary of Benthic Tests Performed with Bronx River Sediment Composites

TABLE 3.10 Summary of Water-Column Toxicity Tests Performed with Bronx River

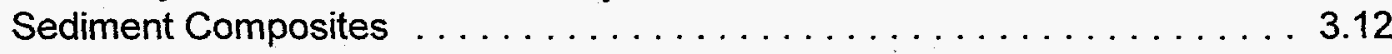

TABLE 3.11 Mean Concentrations of Metals in Macoma nasuta Tissues Exposed to Bronx River Composites and the Mud Dump Reference Site Sediment 


\section{Contents (contd)}

TABLE 3.12 Mean Concentrations of Pesticides in Macoma nasuta Tissue Exposed to Bronx River Composites and Mud Dump Reference Site Sediment . . . 3.15

TABLE 3.13 Mean Concentrations of PCBs in Macoma nasuta Tissues Exposed to Bronx River Composites and Mud Dump Reference Site Sediment

TABLE 3.14 Mean Concentrations of PAHs and 1,4-Dichlorobenzene in Macoma nasuta Tissues Exposed to Bronx River Composites and Mud Dump Reference Site Sediment

TABLE 3.15 Mean Concentrations of Metals in Nereis virens Tissues Exposed to Bronx River Composites and Mud Dump Reference Site Sediment . . . . . . 3.19

TABLE 3.16 Mean Concentrations of Pesticides in Nereis virens Tissues Exposed to Bronx River Composites and Mud Dump Reference Site Sediment . . . . 3.19

TABLE 3.17 Mean Concentrations of PCBs in Nereis virens Tissues Exposed to Bronx River Composites and Mud Dump Reference Site Sediment $\ldots \ldots \ldots \ldots 3.21$

TABLE 3.18 Mean Concentrations of PAHs and 1,4-Dichlorobenzene in Nereis virens Tissues Exposed to Bronx River Composites and Mud Dump Reference

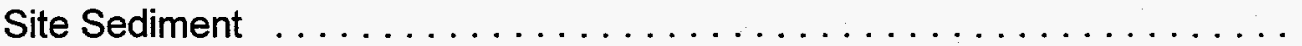

TABLE 3.19 Magnification Factors of All Analyzed Compounds in Tissues Exposed to Bronx River Composites Compared with Mud Dump Reference Site Sediment

TABLE 4.1 Comparison of Contaminant Concentrations in $M$. nasuta and Nereis virens Tissues Exposed to Proposed Dredged Material from Bronx River Project Area with FDA Action Levels and Levels of Concern 


\subsection{Introduction}

\subsection{Project Objectives}

The objective of the Bronx River project was to evaluate proposed dredged material from the Bronx River project area to determine its suitability for unconfined ocean disposal at the Mud Dump Site. Tests and analyses for Mud Dump disposal were conducted on Bronx River sediment core samples according to the manual developed by the U.S. Army Corps of Engineers (USACE) and the U.S. Environmental Protection Agency (EPA), Evaluation of Dredged Material Proposed for Ocean Disposal (Testing Manual) (EPA/USACE 1991), commonly referred to as the "Green Book," and the regional manual developed by the USACENew York District (USACE-NYD) and EPA Region II, Guidance for Performing Tests on Dredged Material to be Disposed of in Ocean Waters (USACE-NYD/EPA Region II 1992), hereinafter referred to as the "Regional Guidance Manual." The Regional Guidance Manual provides specifications for the use of local or appropriate test species in biological tests and identifies chemical contaminants of concern.

As required by the Regional Guidance Manual, the evaluation of proposed dredged material from the Bronx River area consisted of bulk sediment chemical analyses, chemical analyses of dredging site water and elutriate, benthic and water-column acute toxicity tests, and benthic bioaccumulation studies. Individual sediment core samples collected from the Bronx River project area were analyzed for grain size, moisture content, and total organic carbon (TOC). One composite sediment sample representing the entire reach proposed for dredging, was analyzed for bulk density, specific gravity, metals, chlorinated pesticides, polychlorinated biphenyl (PCB) congeners, polynuclear aromatic hydrocarbons (PAHs), and 1,4-dichlorobenzene. Site water and elutriate water that was prepared from the suspended-particulate phase (SPP) of the Bronx River sediment composite were analyzed for metals, pesticides, and PCBs. Benthic acute toxicity tests were performed using the amphipod Ampelisca abdita and the mysid Mysidopsis bahia. Water-column (SPP) toxicity tests were performed using three species, the mysid $M$. bahia, the juvenile silverside Menidia beryllina, and larvae of the mussel Mytilus galloprovincialis. Bioaccumulation tests were conducted on the burrowing, deposit-feeding worm Nereis virens and the surface-detrital-feeding clam Macoma nasuta. 


\subsection{Project Background}

The proposed Bronx River project area was located in Bronx, New York (Figure 1.1). The project requires dredging and disposal of an estimated 1.35 million cu yd of sediment. Project depth of the channel is $41 \mathrm{ft}$ plus $2 \mathrm{ft}$ overdepth ( $43 \mathrm{ft}$ ). Bronx River was one of four waterways that the USACE-NYD requested the Battelle Marine Sciences Laboratory (MSL) to evaluate in a series of dredged material projects that became known as the New York/New Jersey Federal Projects 5 program. The projects evaluated under the Federal Projects 5 program were the Bronx River, Weschester Creek, Shark River, and Cheesequake Creek. Sediment samples from four reaches in these waterways were collected during a survey that took place from May 9 through 12, 1995. Combining sample collection and evaluation of multiple dredged material projects was more costeffective for the USACE-NYD because the expense of sediment sampling, reference site testing, and quality control analyses could be shared among projects.

\subsection{Organization of this Report}

Following this introduction, Section 2 presents the materials and methods used for sample collection, sample processing, sediment sample analysis of physical and chemical parameters, toxicity testing, bioaccumulation testing, statistical data analysis, and quality assurance. Results of all physical/chemical analyses, bioassays, and bioaccumulations are presented in Section 3. A discussion of the results and conclusions is provided in Section 4. Section 5 lists the literature cited in this report. Appendix A contains tabulated results of physical and chemical sediment analyses and quality control data. Appendix $B$ contains results of replicate sample analyses and quality control data for site water and elutriate chemical parameters. Appendix $\mathrm{C}$ contains raw data associated with benthic acute toxicity tests: water quality measurements, test animal survival data, and reference toxicant test results. Similar data for water-column toxicity tests are provided in Appendix D. Appendix E contains water quality measurements, test animal survival data, and reference toxicant test results for the bioaccumulation tests. Appendix $F$ contains replicate sample results and quality control data for chemical analyses of $M$. nasuta tissue samples generated from the bioaccumulation tests, and Appendix $\mathrm{G}$ contains replicate sample results and quality control data for chemical analyses of $N$. virens tissue samples. 


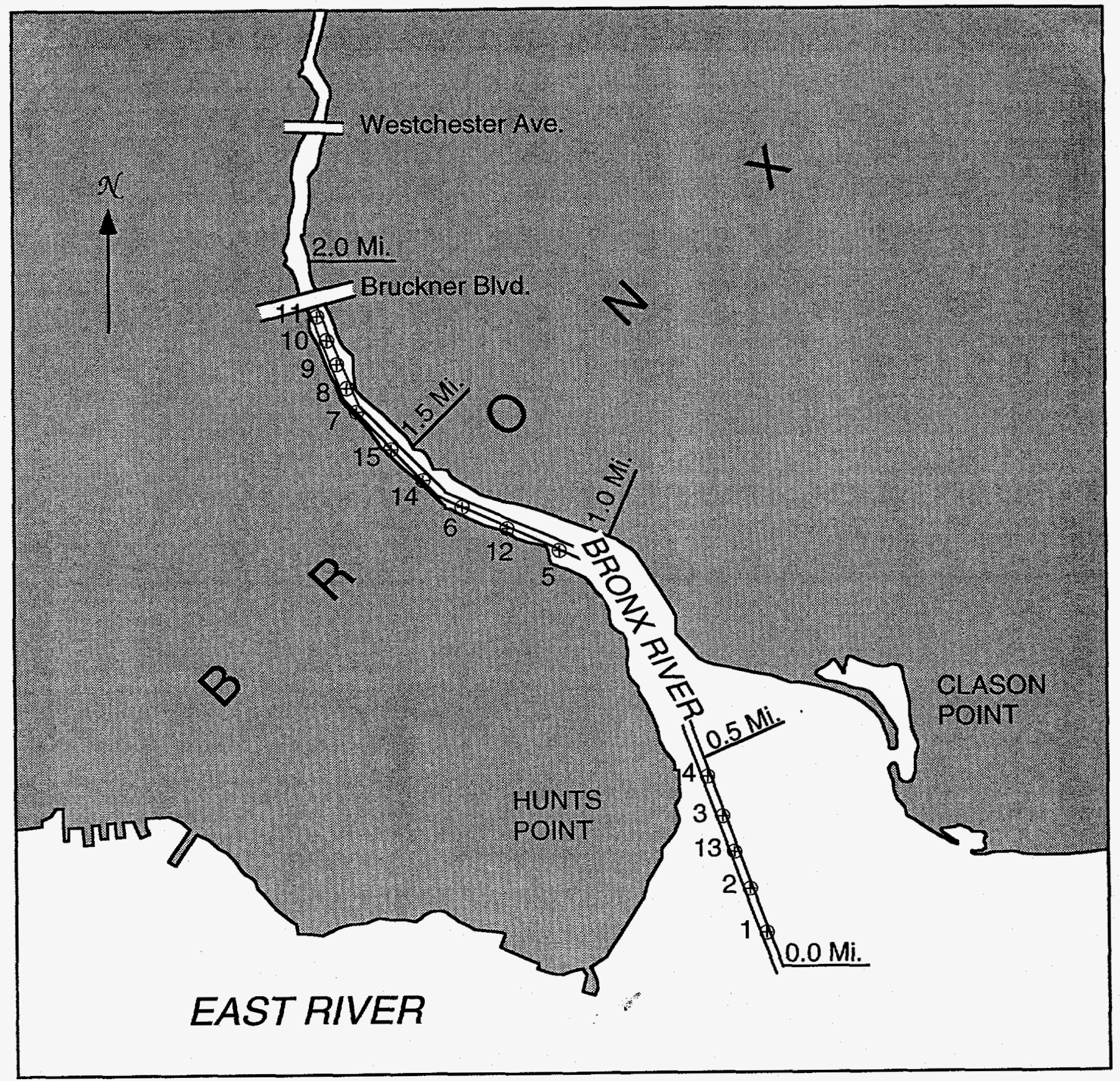

FIGURE 1.1. Location of Bronx River Project Area and Sample Collection Stations 


\subsection{Materials and Methods}

\subsection{Sediment and Water Collection}

Sediment samples were collected from 15 stations within Bronx River project area. Sampling locations were selected by the USACE-NYD based on recent bathymetric surveys. The locations, their coordinates, and water and core sampling depths are presented with the sampling results in Section 3.0. Water samples were collected at a representative location in Bronx River project area and in the Mud Dump Site. Reference sediment was collected from the Mud Dump Reference Site. All samples were collected aboard the MN Gelberman, which is owned and operated by USACE-NYD and located at Caven Point, New Jersey.

\subsubsection{Test Sediment and Site Water Sampling}

The approximate core sampling locations were first determined with the aid of reference to landmarks, such as shoreline features or buoys, as well as by water depth. Then, the vessel's onboard differential-Global Positioning System (dGPS) was used to identify and record (within $5 \mathrm{~m}$ ) each sampling station. The vessel's LORAN was available as a backup system. Water depth at the time of sampling was measured by lead line and confirmed with a fathometer on the boat. The actual water depth was converted to mean lower water (MLW) depth by correcting to the tide height at the time the depth was recorded. The difference between the MLW depth and the project depth, plus $2 \mathrm{ft}$ overdepth, yields the length of core required.

Core samples were collected aboard the MN Gelberman using a submersible vibracore sampler owned and operated by Ocean Surveys, Inc. The vibracore sampler consisted of a 4in. outer diameter, steel core barrel attached to an pneumatic vibratory hammer. The vibratory hammer could be fitted to steel core barrels of various lengths, depending on the length of core needed. To collect a core sample, the core barrel was fitted with a 3.125-in. interior diameter, steam-cleaned, Lexan polycarbonate tube. The vibracore was then suspended by the ship's crane. Once the coring apparatus was directly above the sampling station, the core was lowered through the water to the sediment surface. At this point, the station coordinates were 
recorded from the vessel's dGPS, and water depth from a lead line was recorded. The vibratory hammer was switched on until the corer penetrated through the sediment to the desired project depth. Adequate penetration was determined relative to marks on the outside of the core barrel and on the cable suspending the vibracore from the crane. The vibracore apparatus was then pulled out of the sediment and lowered onto the ship's deck. A cutter-head and core-catcher assembly prevented loss of the sediment through the bottom of the core liner. After each core was brought on board, the liner was pulled from the barrel and the length of cored sediment was measured from the mudline to determine whether the project depth plus 2 $\mathrm{ft}$ overdepth had been reached. If not, the liner was replaced and a second core sample was attempted. If the sediment core length was at least project depth plus $2 \mathrm{ft}$ overdepth, it was capped, sealed with tape, and labeled. If the sediment core length was not to project depth, the sediment sample was discarded and a second core sample was attempted at the same location (within $\sim 20 \mathrm{ft}$ ), until project depth was reached or it was determined that the substrate prevented further penetration of the coring device. While on board the sampling vessel, cores were kept cool $\left(\sim 4^{\circ} \mathrm{C}\right)$ in a freezer on the deck of the boat.

Surface-water samples for dredging site water chemical analysis and SPP preparation were collected at one representative station in the Bronx River project area. Site water was also collected from the Mud Dump Site for chemical analysis and SPP preparation. Water samples were collected using a peristaltic pump, which collected water from several feet below the surface. Water was then transferred to precleaned, 20-L polypropylene carboys, which were previously rinsed with site water three times before filling. Water samples were labeled and kept cool $\left(\sim 4^{\circ} \mathrm{C}\right)$ in a freezer on the deck while on board the boat. Prior to the sampling survey, carboys were washed with hot water and detergent, acid-rinsed with dilute hydrochloric acid, then rinsed with distilled water, followed by acetone.

A log book was maintained containing records of each sample collected, consisting of station designation, coordinates, replicate number, date, sampling time, water depth, and core length. At the end of each sampling day, when the MN Gelberman returned to Caven Point, all sediment cores and water samples were loaded into a locked refrigerated van, thermostatically controlled to maintain temperature at $\sim 4^{\circ} \mathrm{C}$. Sample identification numbers were logged on chain-of-custody forms daily. 
At the conclusion of the sample collection survey, sediment cores and water samples were shipped by refrigerated van from Caven Point, New Jersey, to the MSL in Sequim, Washington. The shipment departed from Caven Point on May 14, 1995, and arrived at the MSL on May 19, 1995.

\subsubsection{Reference and Control Sediment Sampling}

Reference sediments for toxicity and bioaccumulation tests were collected from the Mud Dump Reference Site. Six 5-gal containers of surficial sediment were collected using a van Veen sampler. After recovery, water was drained from the sampler, and the sediments were transferred to epoxy-coated steel buckets. The buckets were covered, labeled, and kept cool $\left(\sim 4^{\circ} \mathrm{C}\right)$ in a freezer on deck while aboard the boat. Records for collected reference sediment included coordinates, replicate number, date, sampling time, and water depth. Reference sediment samples were loaded into the refrigerated van at the staging area upon return to port, and sample identification numbers were logged on chain-of-custody forms.

Control sediments were used in each toxicity and bioaccumulation test to validate test procedures. Control sediment used in $M$. nasuta and $M$. bahia tests was collected from Sequim Bay, Washington, using a van Veen sampler deployed from an MSL research vessel. Native control sediment for $A$. abdita and $N$. virens were supplied with the test organisms by their respective suppliers.

\subsection{Test Organism Collection}

Six species of test organisms were used to evaluate sediment samples from the Bronx River project area:

- Ampelisca abdita, a tube-dwelling, surface detrital-feeding amphipod

- Mysidopsis bahia, a juvenile mysid shrimp

- Menidia beryllina, a juvenile silverside fish

- Mytilus galloprovincialis, the larval zooplankton stage of the mussel

- Macoma nasuta, the bent-nose clam, a burrowing, surface detrital-feeder

- $\quad$ Nereis virens, a burrowing, deposit-feeding polychaete.

All test organisms except mysids and silversides were wild-captured animals, collected by a commercial supplier. The amphipod $A$. abdita was supplied by East Coast Amphipod, 
Kingston, Rhode Island. A. abdita and its native sediment were collected from Narragansett Bay, Rhode Island, by dragging a large dipnet along the sediment surface. Test organisms were carefully removed from their tubes for counting, and then placed in clean, native sediment for overnight transport to the MSL. Mysids were purchased from Aquatic Biosystems, Fort Collins, Colorado. Mysids that were less than $24-h$ old were shipped via overnight delivery in plastic bags containing oxygen-supersaturated seawater maintained at approximately $15^{\circ} \mathrm{C}$ with gel refrigerant packs. Silversides were supplied by Aquatic Research Organisms in Hampton, New Hampshire, and were shipped via overnight delivery in plastic bags containing oxygensupersaturated seawater and packed with gel refrigerant packs to maintain an ambient temperature of approximately $22^{\circ} \mathrm{C}$. Mussels used for obtaining M. galloprovincialis larvae were purchased from the commercial supplier Marinus Inc., Long Beach, California. Mussels were wrapped in moist paper towels and transported in a Styrofoam cooler packed with gel refrigerant packs to maintain an ambient temperature of approximately $15^{\circ} \mathrm{C}$. Clams $(M$. nasuta) were collected from intertidal zones in Discovery Bay, Washington, by Johnston and Gunstone. The clams were kept in large containers filled with sediment and seawater obtained from the collection site and transported to the MSL. Worms (N. virens) were purchased through Envirosystems, Inc., and were collected from an intertidal region in Newcastle, Maine. The worms were packed in insulated boxes with mats of moist seaweed and shipped at ambient temperature to the MSL via overnight delivery.

All organisms were shipped or transported either in native sediment or under other conditions designed to ensure their viability. After their arrival at the MSL, the test organisms were gradually acclimated to test conditions. Animals with abnormal behavior or appearance were not used in toxicological tests. All acclimation and animal care records are part of the raw data files for these projects.

\subsection{Sediment Sample Preparation}

Sediment sample preparation consists of all steps performed in the laboratory between receipt of the samples at the MSL and the preparation of samples for biological testing and physical/chemical analyses. Sediment samples for physical, chemical, and biological analysis 
were prepared from individual core samples, composites of a number of core samples, reference sediment, and control sediment. All sediment samples were assigned random, unique code numbers to ensure that samples are handled without bias by staff in the biology or chemistry laboratories.

Sediment for biological testing was used within the 6-week holding period specified in the Green Book. During this holding time, the sediment samples were received at the MSL; inventoried against chain-of-custody forms; processed and used for benthic and water-column toxicity tests, elutriate analysis, and bioaccumulation tests; and subsampled for sediment physical/chemical analyses. This section describes procedures followed for equipment preparation, compositing strategy, and preparation of sediments for biological testing and chemical analyses.

\subsubsection{Laboratory Preparation and Safety Considerations}

All glassware, stainless-steel or titanium utensils, Nalgene, Teflon, and other laboratory containers and equipment underwent stringent cleaning procedures to avoid contamination of samples. Glassware (e.g., test containers, aquaria, sediment transfer dishes) was washed with hot water and detergent, rinsed with deionized water, then soaked in a $10 \%$ solution of reagent grade nitric acid for a minimum of $4 \mathrm{~h}$ and rinsed again with deionized water before it was allowed to air dry. Polyvinyl chloride (PVC), Nalgene, and Teflon tools were then rinsed with methylene chloride and allowed to dry under a fume hood. Stainless-steel bowls, spoons, spatulas, and other utensils were washed with hot water and detergent, rinsed with deionized water, and allowed to air dry. They were then solvent-rinsed with methylene chloride and allowed to dry under a fume hood.

Neoprene stoppers and polyethylene sheets or other porous materials were washed with hot water and detergent and rinsed with deionized water. These items were then "seasoned" by continuous soaking in 0.45- $\mu \mathrm{m}$ filtered seawater for at least 2 days prior to use. Large pieces of laboratory equipment, such as the epoxy-coated sediment mixer, were washed with a dilute solution of detergent, and thoroughly rinsed with tap water followed by deionized water or filtered seawater. 
Equipment used for determining water quality, including the meters for $\mathrm{pH}$, dissolved oxygen (DO), temperature, ammonia and salinity, were calibrated according to the manufacturers' specifications and internal MSL standard operating procedures (SOPS).

Because the potential toxicity of the Bronx River sediment was unknown, sediment processing and testing were segregated from other laboratory activities. Specific areas at the MSL were established for sample storage and for core-cutting, sediment mixing, and sediment sieving. Work areas were covered with plastic sheeting to contain any waste sediment. Wastewater generated during all operations was retained in 55-gal barrels and periodically pumped through activated charcoal filters and into the MSL's wastewater treatment system. These procedures minimized any potential for cross-contamination of sediment samples and any potential accidental release to the environment.

Laboratory staff members were protected by personal safety equipment such as eyewear, Tyvek suits, plastic aprons, and rubber gloves. Those who were likely to have the most exposure to the potential volatile compounds in the bulk sediment (i.e., those responsible for opening, homogenizing, and compositing core samples) used half-mask respirators.

\subsubsection{Preparation of Sediment for Benthic Testing and Bulk Sediment Analyses}

Each Lexan core liner was opened by scoring the core longitudinally with a circular saw, then finishing the cut and opening the core with a clean, solvent-rinsed linoleum knife to expose the sediment. As each sediment core sample was opened, it was examined for physical characteristics (e.g., sediment type and consistency, color, odor). In particular, the presence of any strata in the cores was noted. All core observations were recorded in the sediment preparation log book. The sediment between the mudline and project depth was then transferred from the core liner to a clean, stainless-steel bowl by scooping the sediment from the core liner with a spoon or spatula. The sediment was mixed by hand with stainless-steel utensils until the color and consistency appeared homogenous, creating a sample representative of the individual sampling station. Sieving was not necessary because organisms that may interfere with test results were not observed in the sediment samples. 
Aliquots of the homogenized sediment were then transferred to the appropriate sample jar(s) for physical or chemical analyses required on individual core samples. A portion of each homogenized core sample was also retained as an archive sample. The remainder of the sediment from the individual core stations was combined in an epoxy coated cement mixer to create a composite sample representing the Bronx River project area, designated COMP BX. The composite contained sediments from Stations BX-1 through BX-15. The composited reach sediment was used for chemical analysis, solid-phase toxicity, and bioaccumulation testing, as required for USACE-NYD. The compositing scheme for these samples is provided in Section 3. Aliquots of homogenized composite sediment were transferred to the appropriate sample jar(s) for physical or chemical analyses required on the composite sample. A portion of the homogenized composited sediment was also retained as an archive sample. The remainder was stored in labeled epoxy-coated pails, tightly covered, at $4^{\circ} \mathrm{C} \pm 2^{\circ} \mathrm{C}$ until use for SPPlelutriate preparation or benthic toxicity and bioaccumulation tests.

The Mud Dump Reference Site sediment, $M$. nasuta native control sediment, and $N$. virens native control sediment were also homogenized in the large, stainless-steel bowls, but prior to mixing, these sediments were pressed through a 1-mm mesh sieve to remove live organisms that might affect the outcome of toxicity tests. After mixing, aliquots for physical and chemical analyses were removed. Native control sediment for $A$. abdita was passed through a 0.5-mm mesh sieve to remove live organisms and mixed in stainless-steel bowis after sieving. All reference and control sediments were stored at $4^{\circ} \mathrm{C} \pm 2^{\circ} \mathrm{C}$ until use in benthic toxicity and bioaccumulation tests.

\subsubsection{Preparation of Suspended-Particulate Phase and Elutriate}

Toxicological effects of dredged sediments dissolved and suspended in the watercolumn at an open-water disposal site were simulated in the laboratory by preparation and testing of the SPP. To prepare the SPP, a sediment-water slurry was created and centrifuged at low speed. The centrifugation procedure replaced the 1-h settling procedure described in the Green Book. Low speed centrifugation provided a more efficient method of SPP preparation and maintained consistency between projects. The SPP was decanted and reserved for testing with water-column organisms. The elutriate phase was prepared by centrifuging the supernatant at a higher speed and collecting the decanted SPP. This liquid was analyzed for 
chemical constituents to identify potential water-soluble contaminants that could remain in the water-column after dredge and disposal operations.

The SPP was prepared by creating a 4:1 (volume:volume) water-to-sediment slurry in 1- $\mathrm{L}$ glass jars with Teflon-lined lids. The jars were marked at $200 \mathrm{~mL}$ and $400 \mathrm{~mL}$ and filled to the 200-mL mark with site water. Homogenized sediment was added until the water was displaced to the 400-mL mark. Each jar was then filled to $1 \mathrm{~L}$ with site water, placed on a shaker table, and agitated for $30 \mathrm{~min}$ at 120 to $150 \mathrm{cycles} / \mathrm{min}$. The slurry was then transferred to $500-\mathrm{mL}$ Teflon jars, tightly sealed, and centrifuged at approximately $1750 \mathrm{rpm}$ for $10 \mathrm{~min}$, at a relative centrifugal force of approximately $1000 \mathrm{~g}$. Following centrifugation, the supernatant was poured into 4- $\mathrm{L}$ glass jars. The Teflon jars were rinsed after each use and the above process continued until an adequate amount of SPP was produced from each composite. Between SPP preparations, all glass and Teflon containers were cleaned according to procedures described in Section 2.3.1. When all SPP for a treatment was prepared, portions were taken for elutriate preparation. The remaining SPP was either used immediately for biological tests or stored at $4^{\circ} \mathrm{C} \pm 2^{\circ} \mathrm{C}$ and used within $24 \mathrm{~h}$ for testing. The $100 \%$ SPP was mixed with Mud Dump Site water to yield three dilutions: $0 \%, 10 \%$, and $50 \%$ SPP, for a total of four concentrations for each sediment composite.

To prepare SPP for elutriate chemistry analyses, a 1-L aliquot of the SPP was collected in an acid-washed Teflon bottle for trace metals analysis, and three 1- $\mathrm{L}$ aliquots were collected in EPA-certified amber glass bottles for analysis of organic compounds. The elutriate for metals analysis was prepared by transferring SPP to acid-washed polycarbonate centrifuge jars, and the elutriate for analysis of organic compounds was prepared by transferring SPP to Teflon centrifuge jars; then both were centrifuged at $2000 \mathrm{rpm}$ for $30 \mathrm{~min}$ at a relative centrifugal force of approximately $1200 \mathrm{~g}$. The decanted supernatant liquid was the elutriate phase. One liter of elutriate was submitted for triplicate trace metals analysis and three $1-\mathrm{L}$ portions were submitted for analysis of organic compounds.

\subsection{Physical and Chemical Analytical Procedures}

Individual sediment cores, composited bulk sediment, water, elutriate, and tissue samples were analyzed for selected physical and chemical parameters. Table 2.1 lists the 
parameters measured in each sample type, the method used for each analysis, and the target analytical detection limits. The following sections briefly describe the procedures used for physical and chemical analyses. Procedures followed those required by the Regional Guidance Manual unless otherwise noted.

\subsubsection{Grain Size and Percentage of Moisture}

Grain size was measured following two methods described by Plumb (1981). The wet sieve method was used to determine the size distribution of sand or coarser-grained particles larger than a U.S. No. 230 standard sieve (62.5 $\mu \mathrm{m}$ mesh). The size distribution of particles smaller than a U.S. No. 230 sieve was determined using the pipet method. Grain size was reported as percentages within four general size classes:

$\begin{array}{ll}\text { gravel } & >2000 \mu \mathrm{m} \text { diameter } \\ \text { sand } & \leq 2000 \mu \mathrm{m} \text { and } \geq 62.5 \mu \mathrm{m} \text { diameter } \\ \text { silt } & <62.5 \mu \mathrm{m} \text { diameter and } \geq 3.9 \mu \mathrm{m} \text { diameter } \\ \text { clay } & <3.9 \mu \mathrm{m} \text { diameter. }\end{array}$

Percentage of moisture was obtained using the Plumb (1981) method for determining total solids. The procedure involves drying a sediment sample at $100^{\circ} \mathrm{C}$ until a constant weight is obtained. Percentage of moisture was calculated by subtracting the percentage of total solids from $100 \%$.

\subsubsection{Bulk Density and Specific Gravity}

Bulk density, or unit weight, was determined according to EM 111-2-1906 (USACE 1970). Specific gravity, the ratio of the mass of a given volume of material to an equal volume of water at the same temperature, was measured according to ASTM D-854.

\subsubsection{TOC}

Samples were analyzed according to the EPA Edison, New Jersey, laboratory procedure (EPA 1986). Inorganic carbon was removed from the sample by acidification. The sample was combusted, and the evolved carbon dioxide was quantitated using a carbonhydrogen-nitrogen ( $\mathrm{CHN}$ ) analyzer. TOC was reported as a percentage of the dry weight of the unacidified sample. 


\subsubsection{Metals}

Preparation and analysis of water samples for $\mathrm{Cd}, \mathrm{Cr}, \mathrm{Cu}, \mathrm{Pb}, \mathrm{Ni}, \mathrm{Ag}$, and $\mathrm{Zn}$ were conducted according to MSL SOPs equivalent to EPA Methods 200.8 (EPA 1991). Aqueous samples were chelated with $2 \%$ ammonium pyrrolidinedithiocarbamate (APDC), precipitated out of solution, and filtered. The filter was digested in concentrated nitric acid, and the digestate was analyzed by graphite furnace atomic absorption (GFAA) spectroscopy for $\mathrm{Cr}$ and $\mathrm{Zn}$ and by inductively coupled plasma/mass spectrometry (ICP/MS) for $\mathrm{Cd}, \mathrm{Cu}, \mathrm{Pb}, \mathrm{Ni}$, and $\mathrm{Ag}$. Water samples were analyzed for $\mathrm{Hg}$ directly by cold vapor atomic fluorescence (CVAF) according to the method of Bloom and Crecelius (1983). This CVAF technique is based on emission of 254$\mathrm{nm}$ radiation by excited elemental $\mathrm{Hg}$ atoms in an inert gas stream. Mercuric ions in an oxidized sample were reduced to elemental $\mathrm{Hg}$ with tin chloride $\left(\mathrm{SnCl}_{2}\right)$, then purged onto goldcoated sand traps to preconcentrate the $\mathrm{Hg}$ and remove interferences. Mercury vapor was thermally desorbed to a second "analytical" gold trap, and from that into the fluorescence cell. Fluorescence (indicated by peak area) is proportional to the quantity of $\mathrm{Hg}$ collected, and was quantified using a standard curve as a function of the quantity of the sample purged.

Sediment samples for analysis of $\mathrm{As}, \mathrm{Cd}, \mathrm{Cr}, \mathrm{Cu}, \mathrm{Pb}, \mathrm{Ni}$, and $\mathrm{Zn}$ were prepared according to an MSL SOP equivalent to EPA Method 200.2 (EPA 1991). Solid samples were first freeze-dried and blended in a Spex mixer mill. A 0.2- to 0.5-g aliquot of dried homogeneous sample was then digested using and nitric acid. Samples were heated in sealed Teflon bombs overnight at approximately $130^{\circ} \mathrm{C}$. Sediment samples were analyzed for $\mathrm{Ag}, \mathrm{As}$, $\mathrm{Cd}, \mathrm{Cr}, \mathrm{Cu}, \mathrm{Pb}, \mathrm{Ni}$, and $\mathrm{Zn}$ using ICP/MS, following an MSL SOP based on EPA Method 200.8 (EPA 1991). Sediments were analyzed for $\mathrm{Hg}$ by CVAA according to an MSL procedure for total $\mathrm{Hg}$ determination equivalent to EPA Method 245.5 (EPA 1991).

Tissue samples were prepared for analysis of metals according to an MSL SOP based on EPA Method 200.3 (EPA 1991). Solid samples were first freeze-dried and blended, and a 0.2- to 0.5-g aliquot of dried homogeneous sample was then digested in a microwave using nitric acid and hydrogen peroxide. Tissue samples were analyzed for $\mathrm{As}, \mathrm{Cd}, \mathrm{Cr}, \mathrm{Cu}, \mathrm{Pb}, \mathrm{Ni}$, $\mathrm{Ag}$, and $\mathrm{Zn}$ using the ICP/MS method (EPA Method 200.8 [EPA 1991]). Tissue samples were analyzed for $\mathrm{Hg}$ by CVAA following an MSL procedure equivalent to EPA Method 245.6 (EPA 1991). 
TABLE 2.1. List of Analytes, Methods, and Target Detection Limits

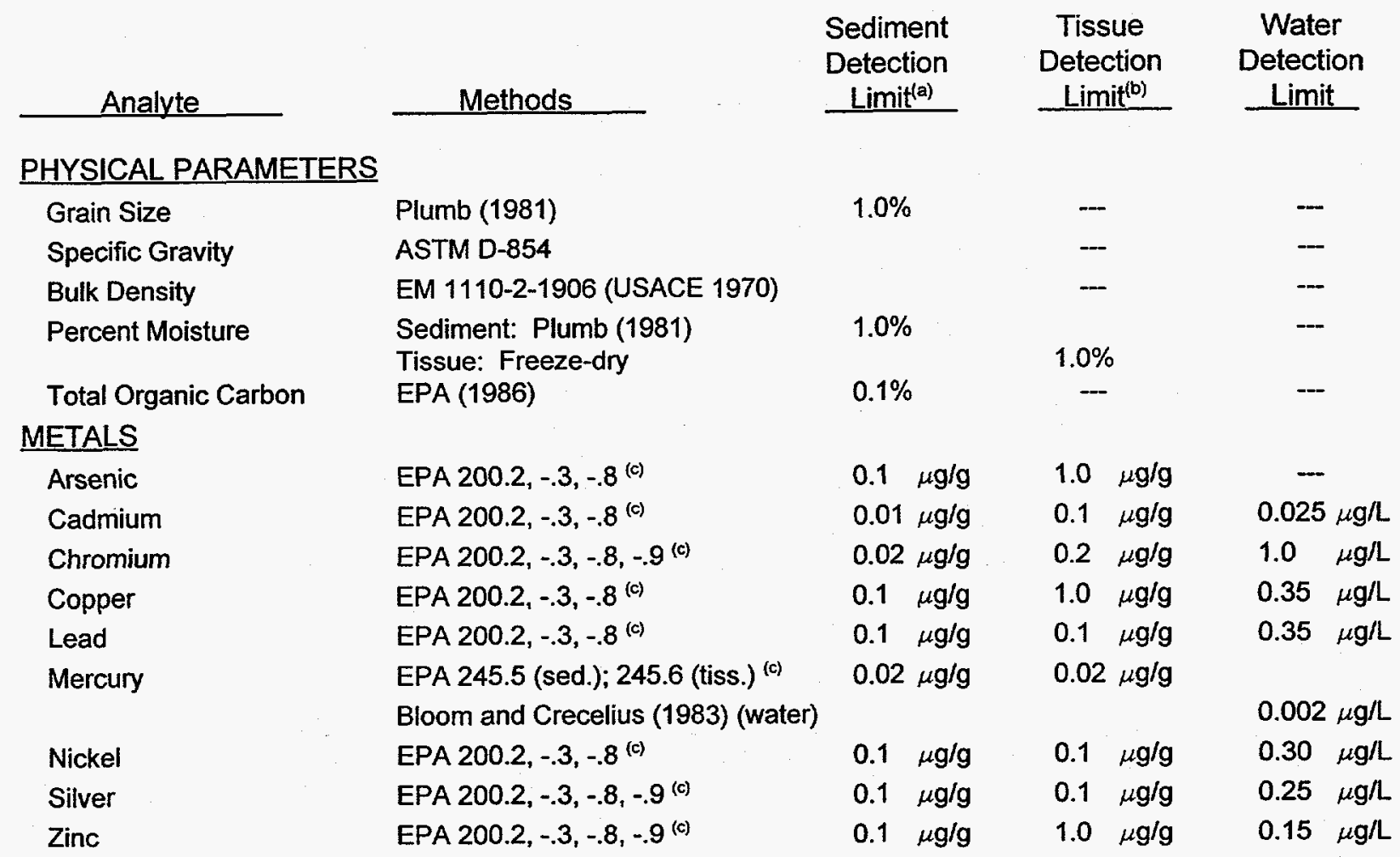

\section{ORGANIC COMPOUNDS}

Pesticides

\begin{tabular}{|c|c|}
\hline Aldrin & $\begin{array}{l}\text { EPA } 8080 \text { (sediment, tissue) } \\
\text { EPA } 608 \text { (water) (c) }\end{array}$ \\
\hline$\alpha$-Chlordane & $\begin{array}{l}\text { EPA } 8080 \text { (sediment, tissue) } \\
\text { EPA } 608 \text { (water) }{ }^{\left({ }^{(}\right)}\end{array}$ \\
\hline trans-Nonachlor & $\begin{array}{l}\text { EPA } 8080 \text { (sediment, tissue) } \\
\text { EPA } 608 \text { (water) (c) }\end{array}$ \\
\hline Dieldrin & $\begin{array}{l}\text { EPA } 8080 \text { (sediment, tissue) } \\
\text { EPA } 608 \text { (water) (c) }\end{array}$ \\
\hline 4,4'-DDT & $\begin{array}{l}\text { EPA } 8080 \text { (sediment, tissue) } \\
\text { EPA } 608 \text { (water) (c) }\end{array}$ \\
\hline 2,4'-DDT & $\begin{array}{l}\text { EPA } 8080 \text { (sediment, tissue) }^{\text {EPA } 608 \text { (water) }^{\left({ }^{c}\right)}}\end{array}$ \\
\hline $4,4^{\prime}-\mathrm{DDD}$ & $\begin{array}{l}\text { EPA } 8080 \text { (sediment, tissue) }^{\text {EPA } 608 \text { (water) }^{\left({ }^{c}\right)}}\end{array}$ \\
\hline 2,4'-DDD & $\begin{array}{l}\text { EPA } 8080 \text { (sediment, tissue) }^{\text {EPA } 608 \text { (water) }^{(c)}}\end{array}$ \\
\hline 4,4'-DDE & $\begin{array}{l}\text { EPA } 8080 \text { (sediment, tissue) }^{\text {EPA } 608 \text { (water) }^{(c)}}\end{array}$ \\
\hline 2,4'-DDE & $\begin{array}{l}\text { EPA } 8080 \text { (sediment, tissue) } \\
\text { EPA } 608 \text { (water) }^{(c)}\end{array}$ \\
\hline
\end{tabular}

$\begin{array}{lllll}1.0 & \mathrm{ng} / \mathrm{g} & 0.4 & \mathrm{ng} / \mathrm{g} & 0.004 \mu \mathrm{g} / \mathrm{L} \\ 1.0 \mathrm{ng} / \mathrm{g} & 0.4 & \mathrm{ng} / \mathrm{g} & 0.014 \mu \mathrm{g} / \mathrm{L} \\ 1.0 \mathrm{ng} / \mathrm{g} & 0.4 & \mathrm{ng} / \mathrm{g} & 0.014 \mu \mathrm{g} / \mathrm{L} \\ 1.0 \mathrm{ng} / \mathrm{g} & 0.4 & \mathrm{ng} / \mathrm{g} & 0.002 \mu \mathrm{g} / \mathrm{L} \\ 1.0 \mathrm{ng} / \mathrm{g} & 0.4 & \mathrm{ng} / \mathrm{g} & 0.012 \mu \mathrm{g} / \mathrm{L} \\ 1.0 \mathrm{ng} / \mathrm{g} & 0.4 & \mathrm{ng} / \mathrm{g} & 0.020 \mu \mathrm{g} / \mathrm{L} \\ 1.0 \mathrm{ng} / \mathrm{g} & 0.4 & \mathrm{ng} / \mathrm{g} & 0.011 \mu \mathrm{g} / \mathrm{L} \\ 1.0 \mathrm{ng} / \mathrm{g} & 0.4 & \mathrm{ng} / \mathrm{g} & 0.020 \mu \mathrm{g} / \mathrm{L} \\ 1.0 \mathrm{ng} / \mathrm{g} & 0.4 & \mathrm{ng} / \mathrm{g} & 0.004 \mu \mathrm{g} / \mathrm{L} \\ 1.0 \mathrm{ng} / \mathrm{g} & 0.4 & \mathrm{ng} / \mathrm{g} & 0.020 \mu \mathrm{g} / \mathrm{L}\end{array}$


IABLE 2.1. (contd)

\begin{tabular}{|c|c|c|c|c|}
\hline Analyte & Methods & $\begin{array}{l}\text { Sediment } \\
\text { Detection } \\
\text { Limit }^{(a)} \\
\end{array}$ & $\begin{array}{c}\text { Tissue } \\
\text { Detection } \\
\text { Limit( }^{(\mathfrak{b})}\end{array}$ & $\begin{array}{c}\text { Water } \\
\text { Detection } \\
\text { Limit }\end{array}$ \\
\hline Endosulfan I & $\begin{array}{l}\text { EPA } 8080 \text { (sediment, tissue) }^{\text {EPA } 608 \text { (water) }^{\text {(c) }}}\end{array}$ & $1.0 \mathrm{ng} / \mathrm{g}$ & $0.4 \mathrm{ng} / \mathrm{g}$ & $0.014 \mu \mathrm{g} / \mathrm{L}$ \\
\hline Endosulfan II & $\begin{array}{l}\text { EPA } 8080 \text { (sediment, tissue) }^{\text {EPA } 608 \text { (water) }^{\text {(c) }}}\end{array}$ & $1.0 \mathrm{ng} / \mathrm{g}$ & $0.4 \mathrm{ng} / \mathrm{g}$ & $0.004 \mu \mathrm{g} / \mathrm{L}$ \\
\hline Endosulfan sulfate & $\begin{array}{l}\text { EPA } 8080 \text { (sediment, tissue) }^{\text {EPA } 608 \text { (water) }^{(c)}}\end{array}$ & $1.0 \mathrm{ng} / \mathrm{g}$ & $0.4 \mathrm{ng} / \mathrm{g}$ & $0.010 \mu \mathrm{g} / \mathrm{L}$ \\
\hline Heptachlor & $\begin{array}{l}\text { EPA } 8080 \text { (sediment, tissue) }^{\text {EPA } 608 \text { (water) }^{\text {(c) }}}\end{array}$ & $1.0 \mathrm{ng} / \mathrm{g}$ & $0.4 \mathrm{ng} / \mathrm{g}$ & $0.003 \mu \mathrm{g} / \mathrm{L}$ \\
\hline Heptachlor epoxide & $\begin{array}{l}\text { EPA } 8080 \text { (sediment, tissue) } \\
\text { EPA } 608 \text { (water) }\end{array}$ & $1.0 \mathrm{ng} / \mathrm{g}$ & $0.4 \mathrm{ng} / \mathrm{g}$ & $0.100 \mu \mathrm{g} / \mathrm{L}$ \\
\hline \multicolumn{5}{|l|}{ PCBs } \\
\hline $8\left(2,4^{\prime}\right)$ & NYSDEC (1992) ${ }^{(c)}$ & $1.0 \mathrm{ng} / \mathrm{g}$ & $0.4 \mathrm{ng} / \mathrm{g}$ & $0.0005 \mu \mathrm{g} / \mathrm{L}$ \\
\hline $18\left(2,2^{\prime}, 5\right)$ & NYSDEC (1992) ${ }^{(c)}$ & $1.0 \mathrm{ng} / \mathrm{g}$ & $0.4 \mathrm{ng} / \mathrm{g}$ & $0.0005 \mu \mathrm{g} / \mathrm{L}$ \\
\hline $28\left(2,4,4^{\prime}\right)$ & NYSDEC (1992) ${ }^{(c)}$ & $1.0 \mathrm{ng} / \mathrm{g}$ & $0.4 \mathrm{ng} / \mathrm{g}$ & $0.0005 \mu \mathrm{g} / \mathrm{L}$ \\
\hline $44\left(2,2^{\prime}, 3,5^{\prime}\right)$ & NYSDEC (1992) ${ }^{(c)}$ & $1.0 \mathrm{ng} / \mathrm{g}$ & $0.4 \mathrm{ng} / \mathrm{g}$ & $0.0005 \mu \mathrm{g} / \mathrm{L}$ \\
\hline $49\left(2,2^{\prime}, 4,5^{\prime}\right)$ & NYSDEC $(1992)^{(c)}$ & $1.0 \mathrm{ng} / \mathrm{g}$ & $0.4 \mathrm{ng} / \mathrm{g}$ & $0.0005 \mu \mathrm{g} / \mathrm{L}$ \\
\hline $52\left(2,2^{\prime}, 5^{\prime}, 5^{\prime}\right)$ & NYSDEC (1992) (c) & $1.0 \mathrm{ng} / \mathrm{g}$ & $0.4 \mathrm{ng} / \mathrm{g}$ & $0.0005 \mu \mathrm{g} / \mathrm{L}$ \\
\hline $66\left(2,3^{\prime}, 4,4^{\prime}\right)$ & NYSDEC (1992) ${ }^{(c)}$ & $1.0 \mathrm{ng} / \mathrm{g}$ & $0.4 \mathrm{ng} / \mathrm{g}$ & $0.0005 \mu \mathrm{g} / \mathrm{L}$ \\
\hline $87\left(2,2^{\prime}, 3,4,5^{\prime}\right)$ & NYSDEC (1992) ${ }^{(\mathrm{c})}$ & $1.0 \mathrm{ng} / \mathrm{g}$ & $0.4 \mathrm{ng} / \mathrm{g}$ & $0.0005 \mu \mathrm{g} / \mathrm{L}$ \\
\hline $101\left(2,2^{\prime}, 3,5,5^{\prime}\right)$ & NYSDEC (1992) ${ }^{(c)}$ & $1.0 \mathrm{ng} / \mathrm{g}$ & $0.4 \mathrm{ng} / \mathrm{g}$ & $0.0005 \mu \mathrm{g} / \mathrm{L}$ \\
\hline $105\left(2,3,3^{\prime}, 4,4^{\prime}\right)$ & NYSDEC $(1992)^{(c)}$ & $1.0 \mathrm{ng} / \mathrm{g}$ & $0.4 \mathrm{ng} / \mathrm{g}$ & $0.0005 \mu \mathrm{g} / \mathrm{L}$ \\
\hline $118\left(2,3^{\prime}, 4,4^{\prime}, 5\right)$ & NYSDEC (1992) ${ }^{(c)}$ & $1.0 \mathrm{ng} / \mathrm{g}$ & $0.4 \mathrm{ng} / \mathrm{g}$ & $0.0005 \mu \mathrm{g} / \mathrm{L}$ \\
\hline $128\left(2,2^{\prime}, 3,3^{\prime}, 4,4^{\prime}\right)$ & NYSDEC (1992) & $1.0 \mathrm{ng} / \mathrm{g}$ & $0.4 \mathrm{ng} / \mathrm{g}$ & $0.0005 \mu \mathrm{g} / \mathrm{L}$ \\
\hline $138\left(2,2^{\prime}, 4,4^{\prime}, 5,5^{\prime}\right)$ & NYSDEC (1992) ${ }^{(c)}$ & $1.0 \mathrm{ng} / \mathrm{g}$ & $0.4 \mathrm{ng} / \mathrm{g}$ & $0.0005 \mu \mathrm{g} / \mathrm{L}$ \\
\hline $153\left(2,2^{\prime}, 4,4^{\prime}, 5,5^{\prime}\right)$ & NYSDEC (1992) ${ }^{(c)}$ & $1.0 \mathrm{ng} / \mathrm{g}$ & $0.4 \mathrm{ng} / \mathrm{g}$ & $0.0005 \mu \mathrm{g} / \mathrm{L}$ \\
\hline $170\left(2,2^{\prime}, 3,3^{\prime}, 4,4^{\prime}, 5\right)$ & NYSDEC (1992) ${ }^{\text {(c) }}$ & $1.0 \mathrm{ng} / \mathrm{g}$ & $0.4 \mathrm{ng} / \mathrm{g}$ & $0.0005 \mu \mathrm{g} / \mathrm{L}$ \\
\hline $180\left(2,2^{\prime}, 3,4^{\prime}, 5^{\prime}, 5^{\prime}, 6\right)$ & NYSDEC (1992) ${ }^{(c)}$ & $1.0 \mathrm{ng} / \mathrm{g}$ & $0.4 \mathrm{ng} / \mathrm{g}$ & $0.0005 \mu \mathrm{g} / \mathrm{L}$ \\
\hline $183\left(2,2^{\prime}, 3,4^{\prime}, 4^{\prime}, 5^{\prime}, 6\right)$ & NYSDEC $(1992)^{(c)}$ & $1.0 \mathrm{ng} / \mathrm{g}$ & $0.4 \mathrm{ng} / \mathrm{g}$ & $0.0005 \mu \mathrm{g} / \mathrm{L}$ \\
\hline $184\left(2,2^{\prime}, 3,4,4^{\prime}, 6,6^{\prime}\right)$ & NYSDEC (1992) ${ }^{(c)}$ & $1.0 \mathrm{ng} / \mathrm{g}$ & $0.4 \mathrm{ng} / \mathrm{g}$ & $0.0005 \mu \mathrm{g} / \mathrm{L}$ \\
\hline $187\left(2,2^{\prime}, 3,4^{\prime}, 5,5^{\prime}, 6\right)$ & NYSDEC (1992) ${ }^{(c)}$ & $1.0 \mathrm{ng} / \mathrm{g}$ & $0.4 \mathrm{ng} / \mathrm{g}$ & $0.0005 \mu \mathrm{g} / \mathrm{L}$ \\
\hline $195\left(2,2^{\prime}, 3,3^{\prime}, 4,4^{\prime}, 5,6\right)$ & NYSDEC (1992) & $1.0 \mathrm{ng} / \mathrm{g}$ & $0.4 \mathrm{ng} / \mathrm{g}$ & $0.0005 \mu \mathrm{g} / \mathrm{L}$ \\
\hline $206\left(2,2^{\prime}, 3,3^{\prime}, 4^{\prime}, 4^{\prime}, 5^{\prime}, 5^{\prime}, 6\right)$ & NYSDEC (1992) ${ }^{(c)}$ & $1.0 \mathrm{ng} / \mathrm{g}$ & $0.4 \mathrm{ng} / \mathrm{g}$ & $0.0005 \mu \mathrm{g} / \mathrm{L}$ \\
\hline $209\left(2,2^{\prime}, 3,3^{\prime}, 4,4^{\prime}, 5,5^{\prime}, 6,6^{\prime}\right)$ & NYSDEC (1992) & $1.0 \mathrm{ng} / \mathrm{g}$ & $0.4 \mathrm{ng} / \mathrm{g}$ & $0.0005 \mu \mathrm{g} / \mathrm{L}$ \\
\hline
\end{tabular}


TABLE 2.1. (contd)

\begin{tabular}{|c|c|c|c|c|c|c|}
\hline Analyte & Methods & \multicolumn{2}{|c|}{$\begin{array}{l}\text { Sediment } \\
\text { Detection } \\
\text { Limit }^{(a)} \\
\end{array}$} & \multicolumn{2}{|c|}{$\begin{array}{c}\text { Tissue } \\
\text { Detection } \\
\text { Limit(b) }^{(b)} \\
\end{array}$} & $\begin{array}{c}\text { Water } \\
\text { Detection } \\
\text { Limit } \\
\end{array}$ \\
\hline \multicolumn{7}{|l|}{ PAHs } \\
\hline Acenapthene & NOAA (1993) ${ }^{(c)}$ & 10 & $\mathrm{ng} / \mathrm{g}$ & 4 & $\mathrm{ng} / \mathrm{g}$ & - \\
\hline Acenaphthylene & NOAA (1993) ${ }^{(0)}$ & 10 & $\mathrm{ng} / \mathrm{g}$ & 4 & $\mathrm{ng} / \mathrm{g}$ & - \\
\hline Anthracene & NOAA (1993) (c) & 10 & $\mathrm{ng} / \mathrm{g}$ & 4 & $\mathrm{ng} / \mathrm{g}$ & - \\
\hline Fluorene & NOAA $(1993)^{(c)}$ & 10 & $\mathrm{ng} / \mathrm{g}$ & 4 & $\mathrm{ng} / \mathrm{g}$ & - \\
\hline Naphthalene & NOAA (1993) (c) & 10 & $\mathrm{ng} / \mathrm{g}$ & 4 & $\mathrm{ng} / \mathrm{g}$ & - \\
\hline Phenanthrene & NOAA $(1993)^{(c)}$ & 10 & $\mathrm{ng} / \mathrm{g}$ & 4 & $\mathrm{ng} / \mathrm{g}$ & - \\
\hline Benz[a]anthracene & NOAA $(1993)^{(c)}$ & 10 & $\mathrm{ng} / \mathrm{g}$ & 4 & $\mathrm{ng} / \mathrm{g}$ & -- \\
\hline Benzo[a]pyrene & NOAA (1993) (c) & 10 & $\mathrm{ng} / \mathrm{g}$ & 4 & $\mathrm{ng} / \mathrm{g}$ & -- \\
\hline Benzo[b]fluoranthene & NOAA $(1993)^{(c)}$ & 10 & $\mathrm{ng} / \mathrm{g}$ & 4 & $\mathrm{ng} / \mathrm{g}$ & - \\
\hline Benzo[ghi]perylene & NOAA $(1993)^{(c)}$ & 10 & $\mathrm{ng} / \mathrm{g}$ & 4 & $\mathrm{ng} / \mathrm{g}$ & - \\
\hline Benzo[k]fluoranthene & NOAA (1993) ${ }^{(c)}$ & 10 & $\mathrm{ng} / \mathrm{g}$ & 4 & $\mathrm{ng} / \mathrm{g}$ & -- \\
\hline Chrysene & NOAA (1993) (c) & 10 & $\mathrm{ng} / \mathrm{g}$ & 4 & $\mathrm{ng} / \mathrm{g}$ & -- \\
\hline Dibenz $[a, h]$ anthracene & NOAA $(1993)^{(c)}$ & 10 & $\mathrm{ng} / \mathrm{g}$ & 4 & $n g / g$ & -- \\
\hline Fluoranthene & NOAA $(1993)^{(c)}$ & 10 & $\mathrm{ng} / \mathrm{g}$ & 4 & $\mathrm{ng} / \mathrm{g}$ & -- \\
\hline Indeno[1,2,3-cd]pyrene & NOAA $(1993)^{(c)}$ & 10 & $\mathrm{ng} / \mathrm{g}$ & 4 & $\mathrm{ng} / \mathrm{g}$ & -- \\
\hline Pyrene & NOAA $(1993)^{(c)}$ & 10 & $\mathrm{ng} / \mathrm{g}$ & 4 & $\mathrm{ng} / \mathrm{g}$ & -- \\
\hline 1,4-Dichlorobenzene & $\operatorname{NOAA}(1993)^{(c)}$ & & $\mathrm{ng} / \mathrm{g}$ & & $\mathrm{ng} / \mathrm{g}$ & -- \\
\hline
\end{tabular}

(a) Detection limits are in dry weight for all sediment parameters except $\mathrm{Hg}$.

(b) Detection limits are in wet weight for all organic and inorganic tissue parameters.

(c) Equivalent Battelle Ocean Sciences or MSL standard operating procedures were substituted for the methods cited. 


\subsubsection{Chlorinated Pesticides and PCBs}

Water samples were prepared and analyzed for chlorinated pesticides and PCBs according to an MSL procedure equivalent to EPA Method 8080 (EPA 1990), and incorporating techniques developed by the National Oceanic and Atmospheric Administration (NOAA) National Status and Trends "Mussel Watch" Program (NOAA 1993). Samples were extracted with methylene chloride. Extract volumes were reduced and solvent-exchanged to hexane. The sample extracts underwent cleanup by alumina and silica column chromatography; further interferences were removed by an additional cleanup treatment using high-performance liquid chromatography (HPLC). Sample extracts were concentrated and analyzed using gas chromatography with electron capture detection (GC-ECD) by the internal standard technique.

Sediment and tissue samples for pesticide and PCB analysis were extracted and analyzed according to an MSL procedure similar to EPA Method 8080 for pesticides and the New York State Department of Environmental Conservation (NYSDEC) Congener-Specific Method 91-11 (NYSDEC 1992). The method also uses techniques from the NOAA Mussel Watch procedure. A $20 \mathrm{gg}$ to $50 \mathrm{~g}$ sample of homogenized sediment or macerated tissue was first combined with sodium sulfate in a sample jar to remove water. Samples were extracted by adding successive portions of methylene chloride and agitating sample jars at ambient temperature using a roller technique. Extract volumes were reduced and solvent-exchanged to hexane, followed by Florisil column chromatography cleanup. Interferences were removed using HPLC cleanup; tissue sample extracts underwent an additional cleanup by gel permeation chromatography (GPC). Sample extracts were concentrated and analyzed using GC-ECD by the internal standard technique.

The concentration of total PCB in each matrix was estimated by taking the sum of the 22 congeners and multiplying by 2 . This procedure for calculation of total PCB was established in 1996 (Mario Del Vicario, Chief of the Marine and Wetlands Protection Branch, U.S. Environmental Protection Agency, Region 2, February 14, 1996, letter to John F. Tavolaro, Chief of Operations Support Branch, U.S. Army Corps of Engineers, New York District). Onehalf of the detection limit was used in summation when an analyte was undetected. 


\subsubsection{PAHs and 1,4-Dichlorobenzene}

Sediment samples were prepared for the analysis of 16 PAHs and 1,4-dichlorobenzene (see Table 2.1) according to an MSL method based on the NOAA Mussel Watch procedure (NOAA 1993). A 20 - to 50-g sample of homogenized sediment or macerated tissue was first combined with sodium sulfate in a sample jar to remove water. Samples were extracted by adding successive portions of methylene chloride and agitating sample jars at ambient temperature using an ambient shaker technique. Extract volumes were reduced and solventexchanged to hexane, followed by column chromatography cleanup. Interferences were removed using HPLC cleanup; tissue sample extracts underwent an additional cleanup by GPC. Sample extracts were concentrated and analyzed using gas chromatography with mass spectrometry (GC/MS) in the selective ion monitoring (SIM) mode.

\subsection{Biological Testing Procedures}

\subsubsection{Benthic Acute Toxicity Tests}

Deposited sediment effects of open-water dredged material disposal were evaluated by benthic acute toxicity tests with the marine amphipod $A$. abdita and the mysid $M$. bahia.

\subsubsection{Static Renewal Test with Ampelisca abdita}

Upon receipt, $A$. abdita were placed in a tub of clean sediment from their collection area and gradually acclimated to laboratory conditions with unfiltered flowing Sequim Bay seawater. A. abdita were received at approximately $15^{\circ} \mathrm{C}$ and acclimated to $20^{\circ} \mathrm{C} \pm 2^{\circ} \mathrm{C}$ over 2 days. The A. abdita were not fed prior to testing.

All amphipod static renewal tests were performed in 1- $L$ glass jars modified for use as flow-through test chambers. The test chambers were fitted with funneled lids and screened overflow ports (Figure 2.1). To prepare each test container, $200 \mathrm{~mL}$ of clean seawater was placed in each jar. Sediment was added until water was displaced to a volume of $400 \mathrm{~mL}$, then seawater was added to a total volume of $750 \mathrm{~mL}$. Five replicates of each Bronx River composite sediment, Mud Dump Reference Site sediment, and native test animal control treatments were tested. 
Concentrations of ammonia have been encountered in the pore water of sediment core samples from New York/New Jersey waterways at concentrations high enough to affect survival of amphipods in benthic toxicity tests (Barrows et al. 1996). Therefore, the A. abdita tests were conducted according to ammonia reduction methods recommended in a correction (errata) to the EPA standard methods document for conduct of benthic acute toxicity tests (EPA 1994a). This guidance recommends postponing test initiation (exposure of test animals) until pore water total ammonia concentrations are below levels at which a toxic effect can be observed. During this "purging" period, test chambers were set up and maintained under test conditions, and the overlying water was exchanged twice daily until the pore water ammonia concentrations reached the appropriate level. The water-supply system was turned on daily to deliver a volume of seawater equivalent to two chamber exchanges per day (approximately 10 min for two times per day). Pore water ammonia measurements were made on "dummy" containers that were set up and maintained in the same manner as the actual test containers but without animals added to them. The pore water was obtained by siphoning off the overlying water in the dummy jar and centrifuging the sediment in a Teflon jar for at least $20 \mathrm{~min}$ at an approximate relative centrifugal force of $780 \times$ gravity. Salinity, temperature, and $\mathrm{pH}$ were also determined in the pore water samples. Once the test was initiated, overlying water was renewed at a rate of two chamber exchanges per day throughout the 10-day tests (approximately 10 min of renewal water flow for two times per day).

The $A$. abdita benthic toxicity tests were initiated by the addition of 20 organisms to each test chamber for a test population of 100 amphipods per sediment treatment. $A$. abdita were gently sieved from their native sediment in holding tanks and transferred to shallow baking dishes. For each test chamber, five animals were counted and transferred by pipet into each of four small, plastic cups. The animals in each transfer cup were recounted by a second analyst. The animals were placed in the test chamber by dipping the cup below the surface of the water to release the amphipods.

Salinity, temperature, $\mathrm{DO}$, and $\mathrm{pH}$ were measured in all replicates prior to test initiation, in at least one replicate per treatment daily, and in all replicates at test termination. Measurements of total ammonia levels in the overlying water and pore water also continued during testing. Overlying water ammonia was measured in all replicates prior to test initiation (Day 0 ), in at least one replicate per treatment daily, and in all replicates at test termination
BRONX RIVER
2.16 


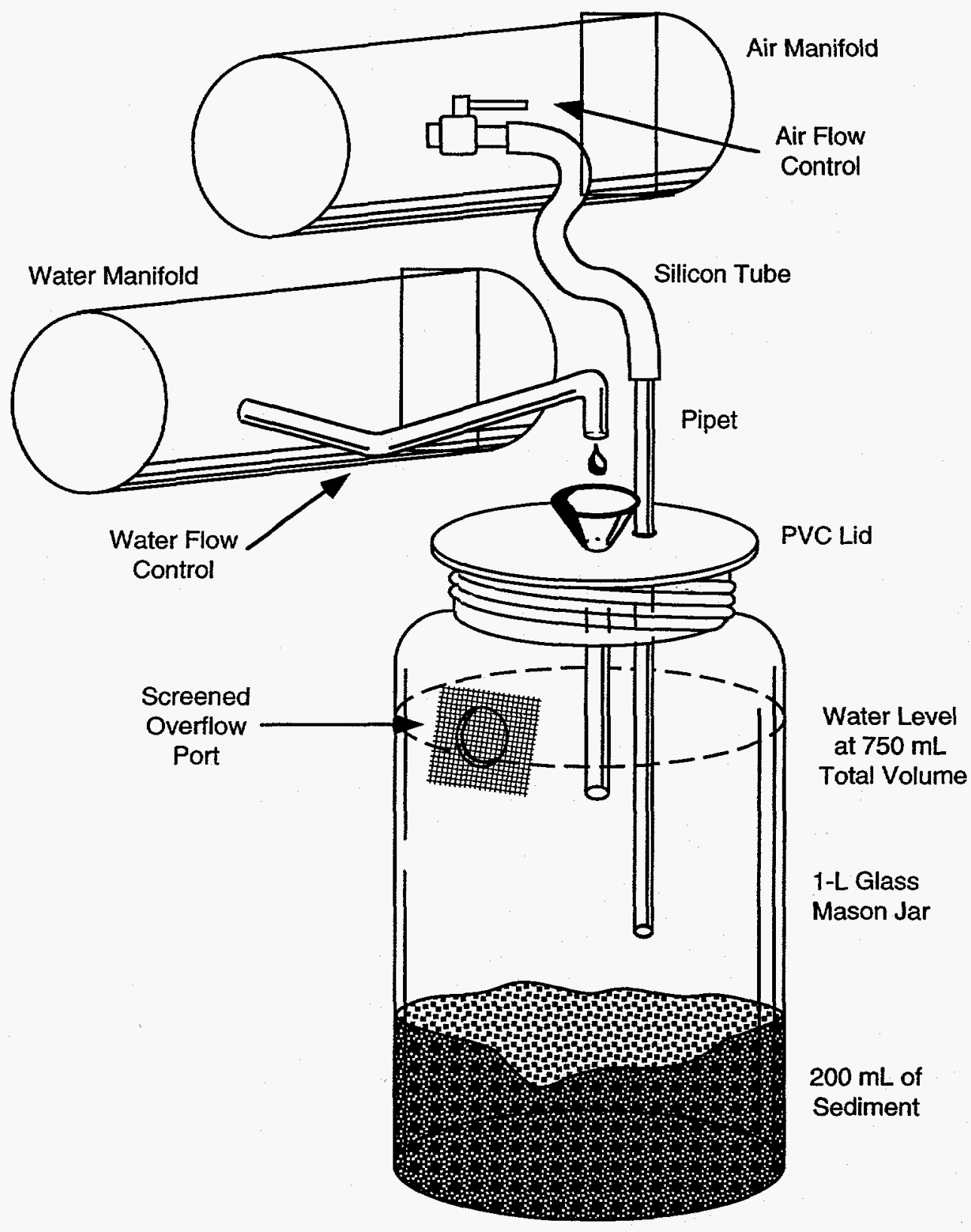

FIGURE 2.1. Testing Containers for Static Renewal Benthic Toxicity Tests 
(Day 10). Pore water ammonia was measured in "dummy" containers on Day 0 and Day 10. The following were the acceptable ranges for water quality parameters during the $A$. abdita test:

$\begin{array}{ll}\text { Temperature } & 20^{\circ} \mathrm{C} \pm 2^{\circ} \mathrm{C} \\ \text { DO } & >60 \% \text { saturation }\left(>4.6 \mathrm{mg} / \mathrm{L} \text { at } 20^{\circ} \mathrm{C}, 30 \% \text { ) }\right. \\ \text { pH } & 7.8 \pm 0.5 \\ \text { Salinity } & 30 \% \pm 2 \% \\ \text { Ammonia } & \leq 20 \mathrm{mg} / \mathrm{L} \text { in pore water at test initiation } \\ \text { Renewal Rate } & 2 \text { exchanges/day. }\end{array}$

The ammonia pore water maximum limit was based on a directive from the USACE-NYD (personal communication, M. Greges, USACE-NYD, April 1995).

Gentle aeration was provided throughout the test, and $A$. abdita were not fed during testing. At the end of the 10-day period, the contents of each chamber were gently sieved through $0.5-\mathrm{mm}$ mesh, and the number of live, dead, and missing $A$. abdita was recorded on termination forms. An animal was considered dead if it did not respond to gentle probing. As a quality control check, a second observer confirmed surviving test organisms on at least $10 \%$ of the termination counts.

Reference toxicant tests with cadmium chloride were performed concurrently with each species. The reference toxicant tests were $96-h$, water-only exposures that were otherwise conducted following the same procedures as for the static tests with sediment. $A$. abdita were exposed to nominal concentrations of $0.0,0.19,0.38,0.75$, and $1.5 \mathrm{mg} / \mathrm{L} \mathrm{Cd}$.

\subsubsection{Static Test with Mysidopsis bahia}

Upon receipt at the laboratory, $M$. bahia were placed in 10-gal aquaria and gradually acclimated from $26 \%$ seawater to $30 \%$ with Sequim Bay seawater over a 48 -h period. M. bahia were received and held for 4 days at $20^{\circ} \mathrm{C} \pm 2^{\circ} \mathrm{C}$ until testing and were fed concentrated brine shrimp nauplii twice daily prior to testing. Mortality of M. bahia during holding was less than $1 \%$.

The 10-day static benthic acute toxicity test with $M$. bahia was performed in 1-L glass jars. To prepare each test container, $200 \mathrm{~mL}$ of clean seawater was placed in each jar. 
Sediment was added until water was displaced up to the $400-\mathrm{mL}$ mark, then seawater was added up to the 750-mL mark. Five replicates of the Bronx River sediment composite and Mud Dump Reference Site sediment were tested. Sequim Bay control sediment was used as a native control sediment for the $M$. bahia test. Exchanges of overlying water were conducted in this test to effect a reduction in pore water ammonia.

The $M$. bahia benthic toxicity test was initiated by the addition of 20 organisms to each test chamber for a test population of 100 mysids per sediment treatment. M. bahia were transferred from holding tanks to shallow glass dishes. For each test chamber, five animals were counted and transferred by pipet into each of four small, plastic cups. The animals in each transfer cup were recounted by a second analyst. The animals were placed in the test chamber by dipping the cup below the surface of the water to release the animals.

Salinity, temperature, $\mathrm{DO}, \mathrm{pH}$, and total ammonia in overlying water were measured in all replicates prior to test initiation, in at least one replicate per treatment daily, and in all replicates at test termination. The following were the acceptable ranges for water quality parameters during the mysid benthic test:

$\begin{array}{ll}\text { Temperature } & 20^{\circ} \mathrm{C} \pm 2^{\circ} \mathrm{C} \\ \text { DO } & >40 \% \text { saturation }\left(>3.0 \mathrm{mg} / \mathrm{L} \text { at } 20^{\circ} \mathrm{C}, 30 \% \text { ) }\right. \\ \text { pH } & 7.8 \pm 0.5 \\ \text { Salinity } & 30 \% \pm 2 \% \\ \text { Ammonia } & \leq 15 \mathrm{mg} / \mathrm{L} \text { in overlying water at test initiation. }\end{array}$

The ammonia overlying water maximum limit was based on EPA guidance (EPA 1994b) that provides criteria of $0.6 \mathrm{mg} / \mathrm{L}$ unionized ammonia at $\mathrm{pH}$ of $7.9-8.0$ and $0.3 \mathrm{mg} / \mathrm{L}$ unionized ammonia at $\mathrm{pH}$ of 7.5 (at $26^{\circ} \mathrm{C}$ and $31 \%$ salinity). When converted to test temperature, $\mathrm{pH}$, and salinity used at the MSL, these values equal approximately $15 \mathrm{mg} / \mathrm{L}$ total ammonia.

Gentle aeration was provided to all test chambers during the test to maintain consistency in DO concentration among test containers. At the end of the 10-day period, the contents of each chamber were gently sieved through $0.5-\mathrm{mm}$ mesh, and the number of live and dead or missing $M$. bahia was recorded on termination forms. An animal was considered dead if it did not respond to gentle prodding. As a quality control check, a second observer confirmed surviving test organisms on at least $10 \%$ of the termination counts. 
Reference toxicant tests with cadmium chloride were performed concurrently with each species. The reference toxicant tests were $96-h$, water-only exposures that were otherwise conducted following the same procedures as for the static tests with sediment. $M$. bahia were exposed to nominal concentrations of $0,150,200,300$, and $400 \mu \mathrm{g} / \mathrm{L} \mathrm{Cu}$.

\subsubsection{Water-Column Toxicity Tests}

Water-column effects of open-water dredged-material disposal were evaluated by exposing three species of water-column organisms to the SPP of the Bronx River sediment composites. The three test species were juvenile $M$. beryllina (silverside) and M. bahia (mysid), and larval M. galloprovincialis (mussel).

\subsubsection{Water-Column Toxicity Test with Menidia beryllina}

Upon receipt, the $M$. beryllina were placed in a 10-gal glass aquarium and gradually acclimated from $22.0 \%$ seawater to $30.0 \%$ Sequim Bay seawater over a 3-day period. M. beryllina were received and held at $20^{\circ} \mathrm{C} \pm 2^{\circ} \mathrm{C}$ prior to testing and were fed concentrated brine shrimp nauplii daily.

Test containers for the water-column toxicity test with silversides were $500-\mathrm{mL}$ glass jars, labeled with sediment treatment code, concentration, position number, and replicate number. Five replicates of each concentration $(0 \%, 10 \%, 50 \%$, and $100 \%$ SPP) were tested, with a $300-\mathrm{mL}$ test volume per replicate. Each test chamber was then placed in a randomly assigned position on a water table at $20^{\circ} \mathrm{C} \pm 2^{\circ} \mathrm{C}$ and allowed to equilibrate to test temperature for several hours. After the SPP concentrations reached test temperature, water quality parameters were measured and recorded for all replicates of all concentrations for each sediment treatment.

To initiate the test, $M$. beryllina were transferred from the holding tank to test chambers with a wide-bore pipet via small transfer cups. Ten individuals were introduced to each test chamber, creating a test population of 50 silversides per concentration for each treatment. Ten animals per test chamber were used, rather than the 20 animals per chamber as described in the Regional Guidance Manual, because it is not possible to make accurate daily observations of $M$. beryllina behavior when using 20 animals. Test initiation time and date were recorded. Following test initiation, water quality parameters were recorded in one replicate of each 
concentration daily. Because several treatments had DO levels lower than $40 \%$ saturation prior to test initiation, all test chambers were aerated to maintain consistency in DO concentration among test containers. Acceptable parameters for this test were as follows:

$\begin{array}{ll}\text { Temperature } & 20^{\circ} \mathrm{C} \pm 2^{\circ} \mathrm{C} \\ \text { DO } & >40 \% \text { saturation } \\ \text { pH } & 7.8 \pm 0.5 \\ \text { Salinity } & 30.0 \% \circ \pm 2.0 \%\end{array}$

The test was run under a 16-h light/8-h dark photoperiod, and silversides were fed brine shrimp nauplii daily during the test. Observations of the animals were performed at $2 \mathrm{~h}, 24 \mathrm{~h}$, $48 \mathrm{~h}$, and $72 \mathrm{~h}$, and the number of live, dead, and missing was recorded. At the end of the $96-\mathrm{h}$ test period, water quality parameters were measured for all test chambers, and the number of live, dead, and missing silversides was recorded on termination forms. As a quality control check, a second observer confirmed surviving organisms on $10 \%$ of the termination counts.

A 96-h, water-only, reference toxicant test was performed concurrently with the toxicity test with each population of $M$. beryllina to establish the health and expected response of the test organisms. The reference toxicant test was conducted in the same manner as the watercolumn toxicity test. $M$. beryllina were exposed to a seawater control plus four concentrations of copper sulfate: $16,64,160$, and $400 \mu \mathrm{g} / \mathrm{L} \mathrm{Cu}$, using three replicates of each concentration.

\subsubsection{Water-Column Toxicity Test with Mysidopsis bahia}

Upon receipt, the $M$. bahia were placed in a 10-gal aquarium and gradually acclimated from $22 \%$ seawater to $30 \%$ Sequim Bay seawater over a 3-day period. Mysids were received and held at $20^{\circ} \mathrm{C} \pm 2^{\circ} \mathrm{C}$ until testing and were fed concentrated brine shrimp nauplii twice daily prior to testing. Mortality of the M. bahia during holding was less than $1 \%$.

The water-column toxicity test with the mysid was performed in $200 \mathrm{~mL}$ of test solution in 400-mL jars, labeled with sediment treatment code, concentration, position number, and replicate number. Five replicates of each concentration were tested. Each of the test chambers received $200 \mathrm{~mL}$ of test solution, then was placed randomly in a recirculating water bath and allowed to equilibrate to test temperature for several hours. Prior to test initiation, 
water quality parameters were measured in each replicate of each sediment treatment concentration. Acceptable water quality parameters for this test were as follows:

$\begin{array}{ll}\text { Temperature } & 20^{\circ} \mathrm{C} \pm 2^{\circ} \mathrm{C} \\ \text { DO } & >40 \% \text { saturation }\left(>3.04 \mathrm{mg} / \mathrm{L} \text { at } 20^{\circ} \mathrm{C}, 30 \%\right) \\ \text { pH } & 7.8 \pm 0.5 \\ \text { Salinity } & 30.0 \% \circ \pm 2.0 \% \text { o. }\end{array}$

To initiate the test, $M$. bahia were transferred from the holding tank to test chambers with a wide-bore pipet via small transfer cups. Ten individuals were introduced to each test chamber, creating a test population of 50 mysids per concentration ( 200 mysids per treatment). Ten animals per test chamber were used, rather than the $\mathbf{2 0}$ animals per chamber as described in the Regional Guidance Manual, because it is not possible to make accurate daily observations of $M$. bahia behavior when using 20 animals. Test initiation time and date were documented on data forms. Observations of test organisms were performed at $4 \mathrm{~h}, 24 \mathrm{~h}, 48 \mathrm{~h}$, and $72 \mathrm{~h}$, using a fluorescent light table to enhance visibility of the $M$. bahia. After test initiation, water quality parameters were measured daily in one replicate concentration of all concentrations for each sediment treatment. During the $96-\mathrm{h}$ exposure, M. bahia were fed $<24-$ h-old brine shrimp daily. Excess food was removed daily with a small pipet, taking care not to disturb test animals. Molted exoskeletons and any particulates from the SPP solutions were also removed.

Prior to test termination, water quality parameters were measured in all replicates. At $96 \mathrm{~h}$, the number of live versus dead animals was recorded for each test container. An animal was considered dead if it did not respond to gentle probing. As a quality control check, a second observer confirmed surviving test organisms on at least $10 \%$ of the termination counts.

A 96- $h$, water-only, reference toxicant test was performed concurrently with the toxicity test with each batch of $M$. bahia to establish the health and expected response of the test organisms. The reference toxicant test was conducted in the same manner as the watercolumn toxicity test. M. bahia were exposed to a seawater control plus four concentrations of copper sulfate: $150,200,300$, and $400 \mu \mathrm{g} / \mathrm{L} \mathrm{Cu}$, using three replicates of each concentration. 


\subsubsection{Water-Column Toxicity Test with Mytilus galloprovincialis Larvae}

Prior to testing, adult M. galloprovincialis were held in flowing, unfiltered Sequim Bay seawater at ambient temperatures for approximately 1 year.

Chambers for the bivalve larvae test were $500-\mathrm{mL}$ glass jars labeled with sediment treatment code, concentration, position number, and replicate number. Dilutions of SPP from sediment composites $(0 \%, 10 \%, 50 \%$, and $100 \%)$ were prepared with $0.45-\mu \mathrm{m}$-filtered Sequim Bay water in a $2000-\mathrm{mL}$ graduated cylinder, then $300 \mathrm{~mL}$ of test solution was transferred into each test chamber. Test chambers were placed in random positions on a water table and allowed to equilibrate to test temperature for several hours. Initial water quality parameters were measured in all replicates once test chambers reached testing temperatures $\left(16^{\circ} \mathrm{C} \pm 2^{\circ} \mathrm{C}\right)$.

Spawning was induced by placing $M$. galloprovincialis into $15^{\circ} \mathrm{C}$, filtered Sequim Bay seawater and rapidly raising the holding water temperature to $20^{\circ} \mathrm{C}$. Spawning occurred within $1 \mathrm{~h}$ of temperature elevation. When spawning began, males and females were identified and isolated in individual jars containing filtered Sequim Bay seawater and allowed to shed gametes for approximately $45 \mathrm{~min}$. Eggs from each female were filtered through a $75-\mu \mathrm{m}$ Nytex screen into separate jars to remove feces, detritus, and byssal fibers. Sperm from at least three males were pooled and $10 \mathrm{~mL}$ of sperm solution was then added to each of the egg stocks. Eggsperm solutions were gently mixed every $10 \mathrm{~min}$ with a perforated plunger. Fertilization proceeded for $1 \mathrm{~h}$, then fertilization rate (percentage of fertilized eggs) was determined by removing a subsample and observing the number of multicell-stage embryos. Fertilization was considered successful if greater than $90 \%$ of the embryos were in the multicell stage. Egg stocks with greater than $90 \%$ fertilization were combined and rinsed on a $20-\mu \mathrm{m}$ Nytex screen to remove excess sperm. Stock embryo solution density was estimated by removing a $0.1-\mathrm{mL}$ subsample and counting all multicell embryos, then multiplying by 10 to yield embryo density (embryos $/ \mathrm{mL}$ ). Stock solution was diluted or concentrated to yield 7500 to $9000 \mathrm{embryos} / \mathrm{mL}$. The test was initiated by introducing $1 \mathrm{~mL}$ of stock solution into each test chamber, to produce embryo densities of 25 to $30 \mathrm{embryos} / \mathrm{mL}$. Test initiation date and time weré recorded on data sheets. Following initiation, $10 \mathrm{~mL}$ stocking-density subsamples were removed from each container and preserved in $5 \%$ formaldehyde to determine actual stocking density later. 
Water quality parameters were measured in one replicate of each concentration per treatment daily throughout the test. Acceptable ranges for water quality parameters were as follows:

$\begin{array}{ll}\text { Temperature } & 16^{\circ} \mathrm{C} \pm 2^{\circ} \mathrm{C} \\ \text { DO } & >60 \% \text { saturation }\left(>4.9 \mathrm{mg} / \mathrm{L} \text { at } 16^{\circ} \mathrm{C}, 30 \% \text { ) }\right. \\ \text { pH } & 7.8 \pm 0.5 \\ \text { Salinity } & 30.0 \% \circ \pm 2.0 \% \text { o. }\end{array}$

Because several treatments had DO levels below the acceptable level of $40 \%$ saturation, each chamber was provided with gentle aeration to maintain consistency in DO concentration among test containers. The bivalve test was terminated after $72 \mathrm{~h}$ when greater than $80 \%$ of the larvae in the controls had reached the D-cell stage. Final water quality parameters were recorded for all replicates. The contents of each chamber were then homogenized with a perforated plunger, and a 10-mL subsample was removed and placed into a 20-mL scintillation vial. The subsample was then fixed with $1 \mathrm{~mL}$ of $50 \%$ solution of formaldehyde in seawater. Samples were scored for the appearance of normal and abnormal D-shaped larvae, blastula larvae, and total number of larvae. At least $10 \%$ of the counts were confirmed by a second observer.

A 72-h reference toxicant test was conducted to verify the health and expected response of the test organisms. The reference toxicant test was setup and conducted in the same manner as the liquid-phase tests. M. galloprovincialis larvae were exposed to a filtered Sequim Bay seawater control plus copper sulfate concentrations of $4,8,16$, and $32 \mu \mathrm{g} / \mathrm{L} \mathrm{Cu}$, with three replicates per concentration.

\subsubsection{Bioaccumulation Testing}

The polychaete $N$. virens and the bivalve $M$. nasuta were used to evaluate the potential bioaccumulation of contaminants from dredged material. The bioaccumulation tests were 28day flow-through exposures to sediment, followed by a 24-h depuration period that allowed the organisms to void their digestive tracts of sediment. $N$. virens and $M$. nasuta were tested in separate 10-gal flow-through aquaria. Animals were exposed to five replicates of each Bronx River sediment composite, Mud Dump Reference Site sediment, and native control sediment. Each chamber contained $25 \mathrm{M}$. nasuta or $20 \mathrm{~N}$. virens. Water quality parameters (temperature, 
$\mathrm{DO}, \mathrm{pH}$, and salinity) were measured in all replicates at test initiation, in at least one replicate per treatment daily, and in all replicates at test termination. Flow rates were measured daily in all chambers.

Upon receipt at the laboratory, $N$. virens were received damp in a mat of seagrass then placed in holding trays of control sediment and sunk in a holding table with heated Sequim Bay seawater flowing into the table. $N$. virens were held at $20^{\circ} \mathrm{C} \pm 2^{\circ} \mathrm{C}$ over a 6-day period. $N$. virens were not fed prior to testing. $M$. nasuta were received damp and held in control sediment with flowing Sequim Bay seawater for 4 days at $15^{\circ} \mathrm{C} \pm 2^{\circ} \mathrm{C}$ until testing and were not fed. Mortality of the $N$. virens and $M$. nasuta during holding was less than $1 \%$.

The Regional Guidance Manual provides an acceptable temperature range of $13^{\circ} \mathrm{C} \pm 1^{\circ} \mathrm{C}$ for $M$. nasuta; however, to maintain consistency with previous New York Federal Project testing, a flow-through filtered seawater temperature of $15^{\circ} \mathrm{C}$ was used. This alteration of test temperature was not expected to affect the outcome of the test; bioaccumulation tests with $M$. nasuta have been conducted at $15^{\circ} \mathrm{C} \pm 2^{\circ} \mathrm{C}$ successfully. After discussion with the USACE-NYD project manager, the following ranges for water quality parameters were established as acceptable for the $M$. nasuta and $N$. virens tests:

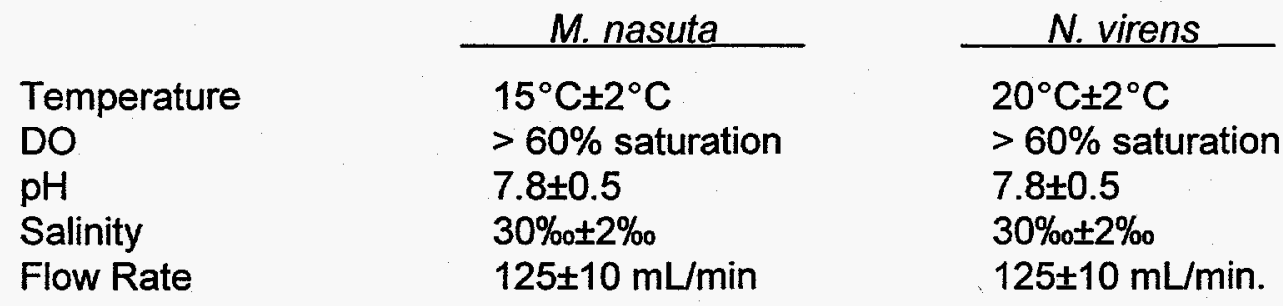

Aeration was provided to all test chambers to maintain consistency in DO concentrations among test chambers. Water quality, organism behavior (e.g., burrowing activity, feeding) and organism mortality were recorded daily. Dead organisms were removed daily. At the end of the 28-day testing period, $M$. nasuta and $N$. virens were placed in clean, flowing seawater for $24 \mathrm{~h}$, after which the tissues were transferred into the appropriate chemistry jars for metals, pesticide/PCB, and PAH analyses. All tissue samples were frozen immediately and stored at $<20^{\circ} \mathrm{C}$ until analysis.

Water-only reference toxicant tests (96-h) were also performed using copper sulfate in six geometrically increasing concentrations. The exposures were conducted using a test 
volume of $5 \mathrm{~L}$ in static $9.5-\mathrm{L}(2.5-\mathrm{gal})$ aquaria. Three replicates of each concentration were tested, each containing 10 organisms. Water quality parameters were monitored at the same frequency and maintained within the same limits as the 28-day test, except that there were no flow rates. The $M$. nasuta reference toxicant test was conducted with treatments of $0,0.31$, $0.63,1.25,2.5$ and $5.0 \mathrm{mg} / \mathrm{L} \mathrm{Cu}$; the $N$. virens test was conducted with treatments of $0,0.05$, $0.075,0.10,0.20,0.30$, and $0.40 \mathrm{mg} / \mathrm{L} \mathrm{Cu}$.

\subsection{Data Analysis and Interpretation Procedures}

Statistical analyses were conducted to determine the magnitude and significance of toxicity and bioaccumulation in test treatments relative to the reference treatment. Each statistical test was based on a completely random design that allowed unbiased comparison between treatments.

\subsubsection{Randomization}

All water-column and benthic toxicity tests were designed as completely random tests. Organisms were randomly allocated to treatments, and treatments were randomly positioned on water tables. To determine randomization, a random-number table was generated for each test using the discrete random-number generator in Microsoft's Excel spreadsheet software.

\subsubsection{Statistical Analysis of Water-Column Tests}

Two statistical analyses are presented in the Green Book for the interpretation of SPP (water-column) tests. The first is a one-sided t-test between survival in control test replicates and survival in the $100 \%$ SPP test replicates. This analysis is to be performed only when survival in the $100 \%$ SPP is less than the control (0\% SPP) survival, and when control survival is $>90 \%$ for nonlarval tests and $>70 \%$ for larval tests (indicating test validity). Prior to conducting the t-test, angular transformation (arcsin of the square root) of the proportion surviving in test replicates was performed to reduce possible heterogeneity of variance between mean survival of test organisms in the control and in the $100 \%$ SPP. The second analysis required by the Green Book is estimation of the medium lethal concentration ( $\mathrm{LC}_{50}$ ) or median effective concentration $\left(E C_{50}\right)$. The $L_{50}$ or $E C_{50}$ values for these tests were estimated using the trimmed Spearman-Karber method (Finney 1971) and are expressed in percentage of SPP. 
The Spearman-Karber estimator is appropriate only if there was increasing mortality (or effect) with increasing concentration, and if $\geq 50 \%$ mortality (or effect) was observed in at least one test concentration when normalized to control survival. If $50 \%$ mortality (or effect) did not occur in the $100 \%$ SPP concentrations for any treatments, then $\mathrm{LC}_{50}$ or $\mathrm{EC}_{50}$ values were reported as $>100 \%$ SPP.

\subsubsection{Statistical Analysis of Benthic Toxicity Tests}

Benthic toxicity of all sediment treatments was compared with a single reference treatment using Dunnett's test (Dunnett 1964). The arcsin square root of the proportion of organisms surviving the test was used to stabilize the within-class variances. As recommended by the Green Book, an experiment-wise error $\alpha=0.05$ was used.

\subsubsection{Statistical Analysis of Bioaccumulation}

Results of the chemical analyses of test organism tissue exposed to the sediment treatments were statistically compared with those tissues similarly exposed to the Mud Dump Reference Site treatment using Dunnett's test with an experiment-wise error of $\alpha=0.05$. The Dunnett's test determined whether or not contaminant body burdens in organisms exposed to the test sediments statistically exceeded those of organisms exposed to the reference sediment.

Statistical analyses were performed on the dry weight concentrations. When a compound (metals, pesticides, PCBs, and PAHs) was undected (indicated by a " $U$ " flag in appendix tables), one-half of the detection limit was used in numerical calculations. If the compound was undetected in all five replicate samples of the COMP BX treatment or the mean concentration of that compound was greater in reference tissue samples than in the COMP BX tissue samples, no further analysis was necessary. If the compound was undetected in all five replicates of the reference treatment, a Mann-Whitney nonparametric t-test $(\alpha=0.05)$ was performed. Results of unexposed or background tissues and control tissue were not statistically compared with the reference. 


\subsection{Quality Assurance/Quality Control Procedures}

The quality assurance/quality control (QAQC) procedures for the Bronx River project were consistent with the Regional Guidance Manual and the Green Book, and were documented in the Work/Quality Assurance Project Plan, Evaluation of Dredged Material Proposed for Ocean Disposal from Federal Projects in New York (Parts 4, 5, and 6), prepared by the MSL and submitted to the USACE-NYD for this program. This document describes all QAVC procedures that were followed for sample collection, sample tracking and storage, and physical/chemical analyses. A member of Pacific Northwest National Laboratory's quality engineering staff was present throughout all phases of this program to observe procedures, review and audit data, and ensure that accepted protocols were followed. Laboratory notebooks or data accumulation notebooks were assigned to each portion of these studies and served as records of day-to-day project activities. Bronx River project samples were analyzed along with samples from the New York/New Jersey Federal Projects 5 Program projects. Because QC samples were associated with a batch of samples, QC analyses may have been conducted on samples from another project analyzed in the same batch as the Bronx River samples. 


\subsection{Results}

This section presents results of sample collection and processing, and physical and chemical analyses conducted on sediment samples collected from the proposed Bronx River dredging area.

\subsection{Sample Collection and Processing}

Sediment core samples were collected from the Bronx River project area on May 11, 1995 (Figure 1.1). Table 3.1 lists each sampling station within the Bronx River project area, sampling coordinates, collection date, length of core required for testing (including $2 \mathrm{ft}$ of overdepth), and length of core actually collected. All samples were collected aboard the MN Gelberman. Fifteen core samples were collected from the Bronx River channel, and all were collected to project depth ( $-10 \mathrm{ft} \mathrm{MLW)} \mathrm{plus} 2 \mathrm{ft}$ of overdepth.

Upon delivery of the sediment core samples to the MSL on May 19, 1995, samples were prepared for the physical and chemical analyses according to the procedures described in Section 2. Individual sediment core samples were analyzed for grain size, moisture content, and TOC. One composited sediment core sample representing the Bronx River project area (COMP BX) was analyzed for bulk density, specific gravity, metals, chlorinated pesticides, PCBs, PAHs, and 1,4-dichlorobenzene. COMP BX consisted of stations BX-1 through BX-15.

\subsection{Physical and Chemical Analyses}

\subsubsection{Sediment Core Sample Description}

Table 3.2 lists physical characteristics of each sediment core sample that was examined. Bronx River sediment samples were generally black, silty-clayey material.

\subsubsection{Grain Size, Percentage of Moisture, Bulk Density, Specific Gravity, and Total Organic Carbon}

Table 3.3 shows the results of the analysis of individual Bronx River core samples for grain size, percentage of moisture, and TOC. A quality control sample summary and associated quality control data for these measurements are provided in Appendix A. 
TABLE 3.1. Summary of Sediment Sample Data for Bronx River Project Area

\begin{tabular}{|c|c|c|c|c|c|c|}
\hline \multirow[b]{2}{*}{ Station } & \multirow{2}{*}{$\begin{array}{c}\text { Collection } \\
\text { Date }\end{array}$} & \multicolumn{2}{|c|}{ dGPS Station Coordinates } & \multirow{2}{*}{$\begin{array}{l}\text { Core Length } \\
\text { Required (ft) }\end{array}$} & \multirow{2}{*}{$\begin{array}{l}\text { Core Length } \\
\text { Collected (ft) }\end{array}$} & \multirow{2}{*}{$\begin{array}{l}\text { Depth } \\
\text { (ft) }\end{array}$} \\
\hline & & Latitude $\mathrm{N}$ & Longitude W & & & \\
\hline$B X-1$ & $5 / 11 / 95$ & $40^{\circ} 48.13^{\prime}$ & $73^{\circ} 51.91^{\prime}$ & 3.4 & 5.0 & 8.6 \\
\hline BX-2 & $5 / 11 / 95$ & $40^{\circ} 48.16^{\prime}$ & $73^{\circ} 51.91^{\prime}$ & 3.0 & 4.8 & 9.0 \\
\hline BX-3 & $5 / 11 / 95$ & $40^{\circ} 48.26^{\prime}$ & $73^{\circ} 51.96^{\prime}$ & 3.0 & 4.0 & 9.0 \\
\hline$B X-4$ & $5 / 11 / 95$ & $40^{\circ} 48.39^{\prime}$ & $73^{\circ} 52.03^{\prime}$ & 3.1 & 4.5 & 8.9 \\
\hline BX-5 & $5 / 11 / 95$ & $40^{\circ} 48.89^{\prime}$ & $73^{\circ} 52.50^{\prime}$ & 3.1 & 4.5 & 8.9 \\
\hline BX-6 & $5 / 11 / 95$ & $40^{\circ} 49.00^{\prime}$ & $73^{\circ} 52.70^{\prime}$ & 3.2 & 4.5 & 8.8 \\
\hline BX-7 & $5 / 11 / 95$ & $40^{\circ} 49.18^{\prime}$ & $73^{\circ} 52.94^{\prime}$ & 2.9 & 4.0 & 9.1 \\
\hline BX-8 & $5 / 11 / 95$ & $40^{\circ} 49.18^{\prime}$ & $73^{\circ} 52.94^{\prime}$ & 5.4 & 5.9 & 6.6 \\
\hline BX-9 & $5 / 11 / 95$ & $40^{\circ} 49.19^{\prime}$ & $73^{\circ} 52.96^{\prime}$ & 4.0 & 4.8 & 8.0 \\
\hline$B X-10$ & $5 / 11 / 95$ & $40^{\circ} 49.31^{\prime}$ & $73^{\circ} 53.04^{\prime}$ & 2.0 & 3.0 & 10.0 \\
\hline$B X-11$ & $5 / 11 / 95$ & $40^{\circ} 49.35^{\prime}$ & $73^{\circ} 53.06^{\prime}$ & 3.7 & 4.7 & 8.3 \\
\hline$B X-12$ & $5 / 11 / 95$ & $40^{\circ} 48.95^{\prime}$ & $73^{\circ} 52.66^{\prime}$ & 2.6 & 5.5 & 9.4 \\
\hline$B X-13$ & $5 / 11 / 95$ & $40^{\circ} 48.21^{\prime}$ & $73^{\circ} 51.90^{\prime}$ & 3.2 & 4.0 & 8.8 \\
\hline$B X-14^{(a)}$ & $5 / 11 / 95$ & $40^{\circ} 49.07^{\prime}$ & $73^{\circ} 52.87^{\prime}$ & 3.0 & 4.0 & 9.0 \\
\hline BX-15 & $5 / 11 / 95$ & $40^{\circ} 49.12^{\prime}$ & $73^{\circ} 52.87^{\prime}$ & 3.4 & 4.0 & 8.6 \\
\hline \multicolumn{7}{|c|}{ Grab Samples } \\
\hline MDRS $^{(\mathbf{b})}$ & $5 / 13 / 95$ & $40^{\circ} 13.91^{\prime}$ & $74^{\circ} 52.13^{\prime}$ & $--^{(c)}$ & - & $N D^{(d)}$ \\
\hline
\end{tabular}

The physical characteristics of Bronx River sediments were predominantly fine grained. Two stations were predominantly sand and gravel (BX-11 and BX-15), whereas the remaining 13 stations were predominantly silt and clay. Percentages of gravel ranged from $0 \%$ to $30 \%$; sand ranged from $6 \%$ to $46 \%$; silt ranged from $17 \%$ to $58 \%$; and clay ranged from $7 \%$ to $45 \%$. Each sediment sample (station) was well represented (at least $10 \%$ ) by two or more grain-size fractions. The Mud Dump Reference Site sediment was composed of $97 \%$ sand. Bulk density and specific gravity were also measured on the Bronx River composite. The bulk density values for COMP BX, reported in both wet and dry weight, were $85 \mathrm{lb} / \mathrm{cu} \mathrm{ft}$ and $35 \mathrm{lb} / \mathrm{cu} \mathrm{ft}$, respectively. The specific gravity value for COMP BX was 2.57 .

With one exception (BX-15), TOC was above $4.0 \%$ in Bronx River sediment. The moisture content ranged from $20 \%$ to $72 \%$ in Bronx River sediment. TOC content in the Mud Dump Reference sediment $(0.07 \%$ TOC) $(20 \%$ moisture) was lower than those in all Bronx 
TABLE 3.2. Bronx River Sediment Core Descriptions

$\frac{\text { Mudline (-ft MLW) }}{\text { Core Project }}$

Station Core Top Bottom Depth(1) Description of Observations

BX-1 $8.6 \quad 13.6 \quad 12.0 \quad$ Uniform black silty/clay to $-11.2 \mathrm{ft} \mathrm{MLW}$. Remaining core was gray clay/silt.

$\begin{array}{llll}\mathrm{BX}-2 & 9.0 & 13.8 & 12.0 \quad \text { Uniform black silty/clay with oily sheen. }\end{array}$

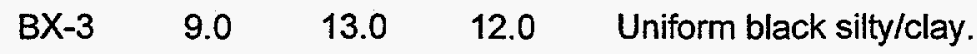

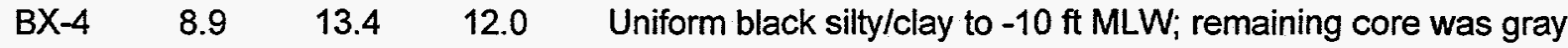
silty/clay.

$\begin{array}{llll}\mathrm{BX}-5 & 8.9 & 13.4 & 12.0 \quad \text { Uniform black silty/clay to }-11 \mathrm{ft} \mathrm{MLW} \text {, remaining core was gray }\end{array}$ sand and clay with some shell hash.

BX-6 $\quad 8.8 \quad 13.3 \quad 12.0 \quad$ Uniform black silt and black silty/clay to $-12 \mathrm{ft}$ MLW, remaining core was gray clay.

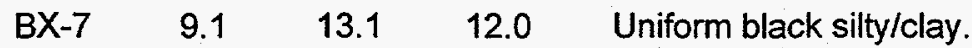

$\begin{array}{lllll}\mathrm{BX}-8 & 6.6 & 12.5 & 12.0 \quad \text { Uniform black silty/clay. }\end{array}$

$\begin{array}{lllll}\text { BX-9 } & 8.0 & 12.8 & 12.0 \quad \text { Uniform black sandy/silt. }\end{array}$

BX-10 $10.0 \quad 13.0 \quad 12.0 \quad$ Uniform black silt.

BX-11 $8.3 \quad 13.0 \quad 12.0 \quad$ Uniform black silty/clay with a band of gray silty/clay at $-10.3 \mathrm{ft}$ MLW to $-10.8 \mathrm{ft} \mathrm{MLW.}$

$\begin{array}{llll}\mathrm{BX}-12 & 9.4 & 14.9 & 12.0 \quad \text { Uniform black silty/clay, with gray clay from }-14.5 \mathrm{ft} \mathrm{MLW} \text { to the }\end{array}$ bottom of the core.

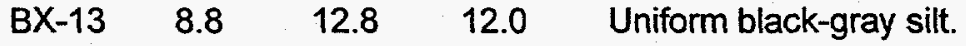

BX-14 $9.0 \quad 13.0 \quad 12.0 \quad$ Uniform black silty/clay with oily sheen. Dense dry brown clay plug.

$\mathrm{BX}-15 \quad 8.6 \quad 12.6 \quad 12.0 \quad$ Uniform black silty/clay to $-9.6 \mathrm{ft}$ MLW. Remaining core was gray silty/sand with some cobble.

(a) Project depth plus $2 \mathrm{ft}$ overdepth.

River core samples. Mud Dump Reference sediment moisture content ( $20 \%$ moisture) was equal to that of $\mathrm{BX}-15$, which was the lowest moisture content of all Bronx River core samples. 
TABLE 3.3. Results of Analysis of Shoal Harbor/Compton Creek Sediment Samples for Grain Size, Total Organic Carbon, and Percentage of Moisture

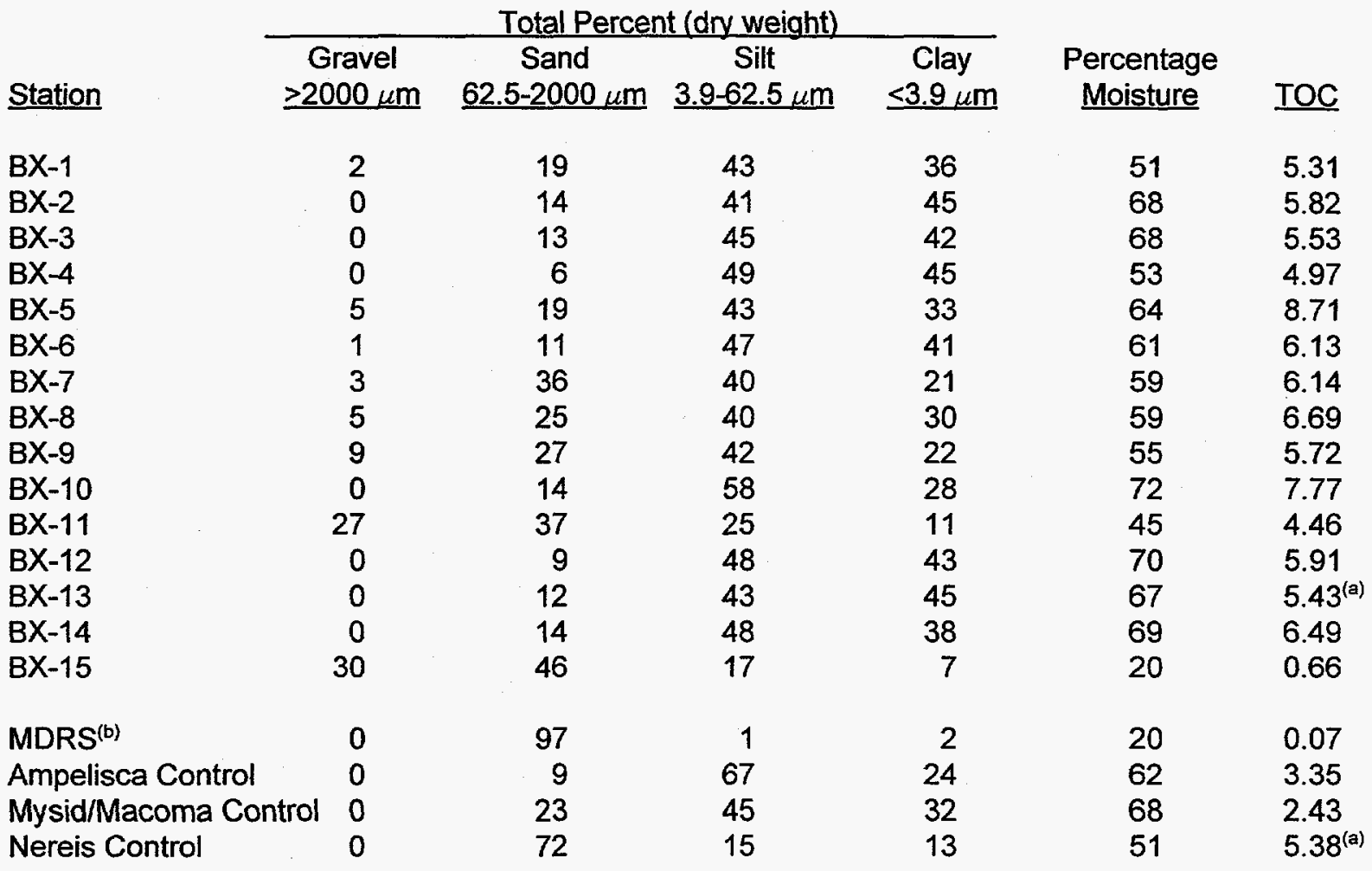

(a) Mean of triplicate analysis.

(b) MDRS Mud Dump Reference Site.

\subsubsection{Metals}

Table 3.4 shows the results of the metals analysis of sediment samples from COMP BX. Quality control data associated with the metals analysis are provided in Appendix A. Dry weight levels of metals in Bronx River sediment ranged from $1.46 \mu \mathrm{g} / \mathrm{g}(\mathrm{Hg})$ to $535 \mu \mathrm{g} / \mathrm{g}(\mathrm{Pb})$.

\subsubsection{Chlorinated Pesticides}

Table 3.5 shows the results of the analysis of Bronx River sediment for chlorinated pesticides. A quality control sample summary and associated quality control data are provided in Appendix A.

The dominant pesticides found in COMP BX were the DDT group of compounds (158 $\mu \mathrm{g} / \mathrm{kg}$ total DDT), followed by $\alpha$-chlordane, trans-nonachlor, aldrin, and endosulfan sulfate. 
TABLE 3.4. Results of Analysis of Bronx River Sediment Samples for Metals

\begin{tabular}{|c|c|c|c|c|c|c|c|c|c|}
\hline & \multicolumn{9}{|c|}{ Metals $(\mu \mathrm{g} / \mathrm{g} \text { dry wt) })^{(\mathrm{a})}$} \\
\hline Sediment Treatment & $\mathrm{Ag}$ & As & $\mathrm{Cd}$ & $\underline{\mathrm{Cr}}$ & $\mathrm{Cu}$ & $\mathrm{Hg}$ & $\underline{\mathrm{Ni}}$ & $\mathrm{Pb}$ & $\underline{Z n}$ \\
\hline COMP BX & 6.90 & 10.7 & 3.80 & 112 & 186 & 1.46 & 38.4 & 535 & 408 \\
\hline
\end{tabular}

\subsubsection{PCBs}

Table 3.5 shows the results of the analysis of the Bronx River sediment for PCBs. A quality control sample summary and associated quality control data are provided in Appendix A.

Eighteen of the $22 \mathrm{PCB}$ congeners were detected in COMP BX sediment. The congeners PCB 8, РCB 28, РCB 184, and РCB 209 were found at a concentration below the detection limit. Total PCB concentrations were calculated as $1660 \mu \mathrm{g} / \mathrm{kg}$ for COMP BX.

\subsubsection{PAHs and 1,4-Dichlorobenzene}

Table 3.6 shows the results of the analysis of the Bronx River sediment for PAHs and 1,4-dichlorobenzene. A quality control sample summary and associated quality control data are provided in Appendix A.

All 16 PAHs analyzed were detected in COMP BX sediment. In COMP BX, lowmolecular-weight PAH (LPAH) made up approximately $16 \%$ of the total PAH concentration, whereas high-molecular-weight PAH (HPAH) made up $84 \%$ of the total. The compound 1,4dichlorobenzene was found at a concentration of $249 \mu \mathrm{g} / \mathrm{kg}$ dry weight in COMP BX. 
TABLE 3.5. Results of Analysis of Bronx River Sediment for Chlorinated Pesticides and Polychlorinated Biphenyls

Analyte

$2,4^{\prime}-\mathrm{DDD}$

$2,4^{\prime}-\mathrm{DDE}$

$2,4^{\prime}-\mathrm{DDT}$

$4,4^{\prime}-D D D$

4,4'-DDE

4,4'-DDT

$\alpha$-Chlordane

Aldrin

Dieldrin

Endosulfan I

Endosulfan II

Endosulfan Sulfate

Heptachlor

Heptachlor Epoxide

trans-Nonachlor

Total DDT ${ }^{(b)}$

Total Detected DDT

PCB 8

PCB 18

PCB 28

PCB 44

PCB 49

PCB 52

PCB 66

PCB 87

PCB 101

PCB 105

PCB 118

PCB 128

PCB 138

PCB 153

PCB 170

PCB 180

PCB 183

PCB 184

PCB 187

PCB 195

PCB 206

PCB 209

Total Estimated $\mathrm{PCB}^{(\mathrm{c})}$

Total Detected PCB
COMP BX

( $\mu \mathrm{g} / \mathrm{kg}$ dry weight)

\section{1}

$1.05 U^{(a)}$

$0.37 \mathrm{U}$

51.7

47.7

33.7

30.6

14.6

$0.32 \mathrm{U}$

$0.55 \mathrm{U}$

$0.55 \mathrm{U}$

4.45

$0.10 \mathrm{U}$

$0.48 \mathrm{U}$

16.3

158

157

$0.87 \mathrm{U}$

151

$0.27 \mathrm{U}$

44.6

31.1

57.4

65.5

16.6

46.0

24.1

48.8

9.57

86.7

77.6

26.1

57.1

24.3

$0.45 \mathrm{U}$

44.6

6.39

10.5

$0.48 \mathrm{U}$

1660

828

(a) $U$ Undetected at or above the given concentration.

(b) Sum of 2,4-DDD, 2,4-DDE, 2,4-DDT, 4,4'-DDD, 4,4'-DDE, and 4,4'-DDT; one-half of the detection limit used in summation when analyte was undetected.

(c) Total $P C B=2(x)$, where $x=$ sum of all PCB congeners detected; one-half of the detection limit used in summation when analyte was undetected. 
TABLE 3.6. Results of Analysis of Bronx River Sediment for PAHs and 1,4-Dichlorobenzene

\section{Analyte}

Naphthalene

Acenaphthylene

Acenaphthene

Fluorene

Phenanthrene

Anthracene

Total LPAH

Fluoranthene

Pyrene

Benz[a]anthracene

Chrysene

Benzo[b+k]fluoranthene

Benzo[a]pyrene

Indeno[123-cd]pyrene

Dibenz[a,h]anthracene

Benzo[g,h,i]perylene

Total HPAH

Total PAH
COMP BX

$\left(\mu \mathrm{g} / \mathrm{kg} \mathrm{dry}\right.$ weight) ${ }^{(\mathrm{a})}$

991

548

594

658

3120

1490

7410

6550

7300

3860

4630

$6010^{\text {(b) }}$

3990

2690

684

2690

38400

45800

1,4-Dichlorobenzene

249

(a) Mean of triplicate analyses.

(b) Benzo[b]fluoranthene and benzo[k[fluoranthene coeluted during analysis, therefore data are sum of both analytes.

\subsection{Site Water and Elutriate Analyses}

Metals, chlorinated pesticides, and PCBs were analyzed in dredging site water collected from Bronx River Project area, and in elutriate samples prepared with Bronx River site water and the Bronx River sediment composite. Sequim Bay control water was also analyzed. All water and elutriate samples were analyzed in triplicate. Mean results of the triplicate analyses are presented and discussed in the following sections. Complete results of all site water and elutriate samples, as well as a quality control summary and associated quality control data are provided in Appendix $B$. 
TABLE 3.7. Results of Analysis of Bronx River Site Water and Elutriate for Metals

\begin{tabular}{|c|c|c|c|}
\hline \multirow[b]{2}{*}{ Analyte } & \multicolumn{3}{|c|}{ Concentration in $\mu g / L^{(a)}$} \\
\hline & $\begin{array}{l}\text { Sequim Bay } \\
\text { Control Water }\end{array}$ & $\begin{array}{l}\text { Bronx River } \\
\text { Site Water }\end{array}$ & $\begin{array}{l}\text { Bronx River } \\
\text { Elutriate }\end{array}$ \\
\hline $\mathrm{Ag}$ & $0.0090 \mathrm{Q}^{(\mathrm{b})}$ & 0.0770 & 0.0862 \\
\hline $\mathrm{Cd}$ & 0.0666 & 0.0734 & 0.0525 \\
\hline $\mathrm{Cr}$ & 0.69 & 1.16 & 1.21 \\
\hline $\mathrm{Cu}$ & 0.607 & 5.42 & 4.54 \\
\hline $\mathrm{Hg}$ & $\ldots$ (c) & 0.0153 & 0.0147 \\
\hline $\mathrm{Ni}$ & 0.455 & 1.64 & 1.14 \\
\hline $\mathrm{Pb}$ & $0.0055 \mathrm{Q}$ & 2.95 & 2.23 \\
\hline $\mathrm{Zn}$ & 1.61 & 20.2 & 8.13 \\
\hline
\end{tabular}

(a) Results shown are the mean of triplicate analyses. If any constituents were undetected, one-half of the detection limit was used in calculation of the mean concentration.

(b) Q Undetected at or above twice the given concentration.

(c) - Not Analyzed.

\subsubsection{Metals}

Results of analysis of Bronx River site water and elutriate are shown in Table 3.7. Sequim Bay seawater was also analyzed as a control. All metals analyzed were detected in both site water and elutriate.

\subsubsection{Chlorinated Pesticides and PCBs}

Results of analysis of Bronx River site water and elutriate and Sequim Bay control water for chlorinated pesticides and PCBs are shown in Table 3.8. Low concentrations of 4,4'-DDD, DDE, and -DDT, dieldrin, and heptachlor epoxide, as well as PCBs 18 and 153 were detected in the site water samples. More pesticides and PCBs were detected in the elutriate than in the site water samples, and concentrations were slightly higher.

\subsection{Water-Column and Benthic Toxicity Testing}

Both benthic and water-column toxicity tests were performed on the Bronx River sediment composite. Benthic acute toxicity tests were performed using the infaunal amphipod A. abdita and the mysid M. bahia. SPP tests (water-column tests) were conducted using the 
TABLE 3.8. Results of Analysis of Bronx River Site Water and Elutriate for Chlorinated Pesticides and PCBs

\begin{tabular}{|c|c|c|c|}
\hline \multirow[b]{2}{*}{ Analyte } & \multicolumn{3}{|c|}{ Concentration in $n g / L^{(a)}$} \\
\hline & $\begin{array}{l}\text { Sequim Bay } \\
\text { Control Water }\end{array}$ & $\begin{array}{l}\text { Bronx River } \\
\text { Site Water }\end{array}$ & $\begin{array}{c}\text { Bronx River } \\
\text { Elutriate } \\
\end{array}$ \\
\hline 2,4'-DDD & $0.50 \mathrm{Q}^{(\mathrm{b})}$ & $0.47 \mathrm{Q}$ & $0.48 \mathrm{Q}$ \\
\hline 2,4'-DDE & $0.12 Q$ & $0.12 \mathrm{Q}$ & $0.12 \mathrm{Q}$ \\
\hline 2,4'-DDT & $0.23 Q$ & $0.22 Q$ & $0.22 \mathrm{Q}$ \\
\hline 4,4'-DDD & $0.24 Q$ & 1.72 & 8.44 \\
\hline 4,4'-DDE & $0.15 \mathrm{Q}$ & 2.82 & 9.21 \\
\hline 4,4'-DDT & $0.22 \mathrm{Q}$ & 1.73 & 10.3 \\
\hline Total Estimated $D D T^{(c)}$ & 1.46 & 7.08 & 28.8 \\
\hline Total Detected DDT & 0.00 & 6.27 & 28.0 \\
\hline$\alpha$-Chlordane & $0.44 \mathrm{Q}$ & $0.41 \mathrm{Q}$ & 1.78 \\
\hline Aldrin & $0.21 \mathrm{Q}$ & $0.19 \mathrm{Q}$ & $0.20 \mathrm{Q}$ \\
\hline Dieldrin & $0.07 \mathrm{Q}$ & 3.40 & 5.51 \\
\hline Endosulfan I & $0.25 \mathrm{Q}$ & $0.23 \mathrm{Q}$ & $0.24 \mathrm{Q}$ \\
\hline Endosulfan II & $0.25 \mathrm{Q}$ & $0.23 Q$ & 0.83 \\
\hline Endosulfan Sulfate & $0.25 \mathrm{Q}$ & $0.23 \mathrm{Q}$ & 0.38 \\
\hline Heptachlor & $0.25 \mathrm{Q}$ & $0.23 \mathrm{Q}$ & 0.45 \\
\hline Heptachlor Epoxide & $0.06 \mathrm{Q}$ & 0.54 & $0.06 \mathrm{Q}$ \\
\hline trans-Nonachlor & $0.59 \mathrm{Q}$ & $0.55 \mathrm{Q}$ & 0.80 \\
\hline РCB 8 & $0.53 \mathrm{Q}$ & $0.49 \mathrm{Q}$ & $0.51 \mathrm{Q}$ \\
\hline PCB 18 & $0.56 \mathrm{Q}$ & 0.86 & 21.5 \\
\hline PCB 28 & $0.38 \mathrm{Q}$ & $0.35 \mathrm{Q}$ & 9.12 \\
\hline PCB 44 & $0.17 \mathrm{Q}$ & $0.15 \mathrm{Q}$ & $0.16 \mathrm{Q}$ \\
\hline PCB 49 & $0.29 \mathrm{Q}$ & $0.27 \mathrm{Q}$ & 3.78 \\
\hline PCB 52 & $0.19 Q$ & $0.18 \mathrm{Q}$ & $0.18 \mathrm{Q}$ \\
\hline PCB 66 & $0.21 \mathrm{Q}$ & $0.19 \mathrm{Q}$ & $0.20 \mathrm{Q}$ \\
\hline PCB 87 & $0.19 \mathrm{Q}$ & $0.18 \mathrm{Q}$ & 1.29 \\
\hline PCB 101 & $0.26 \mathrm{Q}$ & $0.24 Q$ & 4.70 \\
\hline PCB 105 & $0.16 \mathrm{Q}$ & $0.15 \mathrm{Q}$ & $0.15 \mathrm{Q}$ \\
\hline PCB 118 & $0.25 \mathrm{Q}$ & $0.23 \mathrm{Q}$ & 3.66 \\
\hline PCB 128 & $0.13 \mathrm{Q}$ & $0.12 \mathrm{Q}$ & $0.12 \mathrm{Q}$ \\
\hline PCB 138 & $0.18 \mathrm{Q}$ & $0.17 \mathrm{Q}$ & 5.14 \\
\hline PCB 153 & $0.21 Q$ & 0.43 & 7.51 \\
\hline РCB 170 & $0.11 \mathrm{Q}$ & $0.10 \mathrm{Q}$ & 0.46 \\
\hline PCB 180 & $0.15 Q$ & $0.14 Q$ & 5.33 \\
\hline PCB 183 & $0.29 \mathrm{Q}$ & $0.27 \mathrm{Q}$ & 0.94 \\
\hline PCB 184 & $0.29 Q$ & $0.27 \mathrm{Q}$ & $0.27 \mathrm{Q}$ \\
\hline PCB 187 & $0.21 Q$ & $0.19 Q$ & 2.47 \\
\hline PCB 195 & $0.15 \mathrm{Q}$ & $0.14 Q$ & $0.14 \mathrm{Q}$ \\
\hline PCB 206 & $0.21 Q$ & $0.20 \mathrm{Q}$ & $0.20 \mathrm{Q}$ \\
\hline РСВ 209 & $0.15 Q$ & $0.14 Q$ & 0.52 \\
\hline Total Estimated $\mathrm{PCB}^{(\mathrm{d})}$ & 10.5 & 10.9 & 137 \\
\hline Total Detected PCB & 0.00 & 1.29 & 66.4 \\
\hline
\end{tabular}

(a) Results shown are the mean of triplicate analyses. If any constituents were undetected, one-half of the detection limit was used in calculation of the mean concentration.

(b) $Q$ Undetected at or above twice the given concentration.

(c) Total estimated DDT is the sum of 4, ' '-DDT, 4, 4'-DDE, 4,4'-DDD, 2,4'-DDT, 2,4'-DDE, and 2,4'-DDD. One-half of the detection limit was used in summation when constituent was not detected.

(d) Total PCB $=2(x)$, where $x=$ sum of all 22 PCB congeners; one-half of the detection limit used in summation when analyte was undetected. 
juvenile silverside $M$. beryllina, the mysid $M$. bahia, and larvae of the bivalve $M$. galloprovincialis. This section discusses the results of all sediment and reference-toxicant testing. Complete test results, water quality measurements, and the results of the reference-toxicant tests are presented in Appendix $C$ for benthic tests, and Appendix $D$ for water-column test results. Throughout this section, the term "significant difference" is used to express statistically significant differences at $\alpha=0.05$ only. Tests for statistical significance between test treatments and control or reference treatments were performed following methods outlined in Section 2.6.

\subsubsection{Ampelisca abdita Benthic Acute Toxicity Test}

Results of the static renewal, benthic acute toxicity test with $A$. abdita are summarized in Table 3.9. Complete test results and water quality data are presented in Appendix C, Tables C. 1 through C.4. Survival in the $A$. abdita control sediment was $98 \%$, validating this test. Amphipod survival was $65 \%$ for COMP BX, and $95 \%$ in the Mud Dump Reference. A. abdita survival in COMP BX was significantly different than in the Mud Dump Reference, and $\geq 20 \%$ different than the survival in the Mud Dump Reference.

Water quality parameters were within acceptable ranges throughout the test, except for minor deviations in $\mathrm{pH}$ measurements rising to 8.42 in COMP BX. The $\mathrm{Cd}$ reference toxicant test produced an $\mathrm{LC}_{50}$ of $0.64 \mathrm{mg} / \mathrm{L} \mathrm{Cd}$, within the control range (mean \pm 2 standard deviations) established other at the MSL $(0.4 \mathrm{mg} / \mathrm{L}$ to $0.9 \mathrm{mg} / \mathrm{L} \mathrm{Cd})$. After addition of sediment to test chambers, overlying water was renewed twice daily for ammonia reduction for 11 days before test initiation. Prior to ammonia reduction procedures total ammonia in COMP BX pore water was measured at $102 \mathrm{mg} / \mathrm{L}$. Test chambers were renewed twice daily during the 10-day test. At test termination, total ammonia concentrations were less than $1.0 \mathrm{mg} / \mathrm{L}$ in the overlying water and less than $23 \mathrm{mg} / \mathrm{L}$ in the COMP BX pore water.

\subsubsection{Mysidopsis bahia Benthic Acute Toxicity Test}

Results of the static, benthic acute toxicity test with $M$. bahia are summarized in Table 3.9. Complete test results and water quality data are presented in Appendix $C$, Tables $C .5$ through C.8. Survival was $96 \%$ in COMP BX and $91 \%$ in the Mud Dump Reference Site. The control 
TABLE 3.9. Summary of Benthic Tests Performed with Bronx River Sediment Composites

\begin{tabular}{|c|c|c|c|c|}
\hline $\begin{array}{l}\text { Test Organism } \\
\text { and Composite }\end{array}$ & $\begin{array}{l}\text { Mean \% } \\
\text { Survival }\end{array}$ & $\begin{array}{c}\text { Significantly } \\
\text { Different Than } \\
\text { MDRS }^{\text {(a) }} \\
\end{array}$ & $\begin{array}{c}220 \% \\
\text { Difference } \\
\text { from MDRS }\end{array}$ & $\begin{array}{c}\geq 10 \% \\
\text { Difference } \\
\text { from MDRS }\end{array}$ \\
\hline A. abdita (COMP BX) & $65 \%$ & Yes & Yes & -_(b) \\
\hline A. abdita (MDRS) & $95 \%$ & -- & -- & -- \\
\hline A. abdita (Control) & $98 \%$ & -- & -- & -- \\
\hline M. bahia (COMP BX) & $96 \%$ & No & -- & No \\
\hline M. bahia (MDRS) & $91 \%$ & -- & -- & -- \\
\hline M. bahia (Control) & $92 \%$ & -- & -- & - \\
\hline
\end{tabular}

(a) MDRS Mud Dump Reference Site.

(b) - Not Applicable.

sediment was $92 \%$, validating the test. $M$. bahia survival in COMP BX was not significantly different than in the Mud Dump Reference Site treatment.

All water quality parameters were within acceptable ranges throughout the test, except for minor deviations in pH measurements rising to 8.51 in COMP BX and to 8.63 in the control. The Cu reference toxicant test produced an $\mathrm{LC}_{50}$ of $263 \mu \mathrm{g} / \mathrm{L} \mathrm{Cu}$, which was within the control range established at the MSL $(154 \mu \mathrm{g} / \mathrm{L}$ to $303 \mu \mathrm{g} / \mathrm{L} \mathrm{Cu})$. After addition of sediment to test chambers, overlying water was renewed twice daily for ammonia reduction for 5 days before test initiation. Prior to ammonia reduction procedures total ammonia in COMP BX porewater was measured at $102 \mathrm{mg} / \mathrm{L}$. During the test, the ammonia concentrations were less than $14.0 \mathrm{mg} / \mathrm{L}$ in the COMP BX overlying water and less than $24 \mathrm{mg} / \mathrm{L}$ in the pore water. Test chambers were not renewed during the 10-day exposure.

\subsubsection{Menidia beryllina Water-Column Toxicity Test}

Results of the M. beryllina water-column toxicity test are summarized in Table 3.10. Complete test results and water quality data, are presented in Appendix D, Tables D. 1 through D.4. Control survival was $90 \%$, therefore validating the test. Survival in the $100 \%$ SPP was $0 \%$ for COMP BX. A significant reduction in survival was observed in the $100 \%$ SPP, relative to the control treatment. The M. beryllina $\mathrm{LC}_{50}$ was $21.5 \%$ SPP for COMP BX. 
TABLE 3.10. Summary of Water-Column Toxicity Tests Performed with Bronx River Sediment Composites

$0 \%$ and $100 \%$

\begin{tabular}{|c|c|c|c|c|c|}
\hline Composite & Test Organism & $\begin{array}{l}\text { Survival in } \\
\text { 0\% SPP }\end{array}$ & $\begin{array}{l}\text { Survival in } \\
100 \% \text { SPP }\end{array}$ & $\begin{array}{c}\text { Significantly } \\
\text { Different }\end{array}$ & $\mathrm{LC}_{50}(\% \mathrm{SPP})$ \\
\hline COMP BX & M. beryllina & $90 \%$ & $0 \%$ & Yes & 21.5 \\
\hline СOMP BX & M. bahia & $100 \%$ & $8 \%$ & Yes & 71.6 \\
\hline СOMP BX & M. galloprovincialis & $83 \%$ & $50 \%$ & Yes & $>100$ (survival) \\
\hline COMP BX & M. galloprovincialis & $72 \%$ & $1 \%$ & Yes & $23.6^{(\mathrm{a})}$ (normal) \\
\hline
\end{tabular}

(a) Percent normal development to the D-cell, prodissoconch I stage used to calculate the median-effective concentration $\left(\mathrm{EC}_{50}\right)$.

All water quality parameters were within acceptable ranges throughout the test except for a minor elevation in $\mathrm{pH}$ (8.41) in COMP BX, 100\% SPP. The copper reference toxicant test produced an $\mathrm{LC}_{50}$ of $160 \mu \mathrm{g} / \mathrm{L} \mathrm{Cu}$, which was outside the control range established at the MSL $(79 \mu \mathrm{g} / \mathrm{L}$ to $123 \mu \mathrm{g} / \mathrm{L} \mathrm{Cu}$ ). This indicated that the test organisms were slightly less sensitive than those previously used and may have underestimated toxicity for this SPP.

\subsubsection{Mysidopsis bahia Water-Column Toxicity Test}

Results of the M. bahia water-column toxicity test are summarized in Table 3.10. Complete test results, as well as water quality data, are presented in Appendix D, Tables D.5 through D.8. This test was validated by a control survival of $100 \%$ for BX. Survival in the $100 \%$ SPP preparation was $8 \%$ in COMP BX. COMP BX $100 \%$ SPP survival was significantly lower than the control. The M. bahia $\mathrm{LC}_{50}$ for the BX composite was $71.6 \%$ SPP.

All water quality parameters were within acceptable ranges throughout the test, with the exception of $\mathrm{pH}$. The $\mathrm{pH}$ measurements rose to 8.52 in COMP BX $100 \%$ treatment. The copper reference toxicant test produced an $\mathrm{LC}_{50}$ of $283 \mu \mathrm{g} / \mathrm{L} \mathrm{Cu}$, which was within the control range established at the MSL ( $154 \mu \mathrm{g} / \mathrm{L}$ to $303 \mu \mathrm{g} / \mathrm{L} \mathrm{Cu}$ ). 


\subsubsection{Mytilus galloprovincialis Water-Column Toxicity Test}

Results of the $M$. galloprovincialis water-column toxicity test are summarized in Table 3.10. Complete test results and water quality data are presented in Appendix D, Tables D.9 through D.12. COMP BX showed $72 \%$ normal development and $83 \%$ survival in the controls, thus validating the test. Survival in the $100 \%$ SPP preparation was $50 \%$ for COMP BX. Significantly reduced survival, relative to the controls, was observed in the $100 \%$ SPP treatment of COMP $B X$. The $L_{6}$ was $2100 \%$ SPP for COMP BX. Normal development, which is considered a more sensitive indicator of toxicity, was significantly reduced only in COMP BX $100 \%$ SPP, with $1 \%$ normal prodissoconch I. The $\mathrm{EC}_{50}$ was $23.6 \%$ SPP for COMP BX.

All water quality parameters were within acceptable ranges throughout the test, with the exception of $\mathrm{pH}$, which rose to 8.55 in the COMP BX $100 \%$. The $\mathrm{Cu}$ reference toxicant test produced an $\mathrm{EC}_{50}$ of $12.2 \mu \mathrm{g} / \mathrm{L} \mathrm{Cu}$, which is above the control range established for $\mathrm{Cu}$ at MSL $\left(E_{50}: 4.6 \mu \mathrm{g} / \mathrm{L}\right.$ to $\left.9.2 \mu \mathrm{g} / \mathrm{L} \mathrm{Cu}\right)$.

\subsection{Bioaccumulation Tests with Macoma nasuta and Nereis virens}

Bioaccumulation tests with $M$. nasuta and $N$. virens were conducted using the Bronx River composite, the Mud Dump Reference Site sediments, and control sediments for each species. Both $M$. nasuta and $N$. virens were exposed for 28 days under flow-through conditions. Survival was $90 \%$ in the $M$. nasuta control exposure, and was $76 \%$ in the $N$. virens control exposure. The mean lipid content measured in the background tissue samples were $0.86 \%$ for $M$. nasuta and $1.13 \%$ for $N$. virens. No statistically significant differences in $M$. nasuta survival were observed between the Bronx River composite and the reference sediment. A statistically significant difference in $N$. virens survival was found between the Bronx River composite and the reference sediment.

The tissues of organisms exposed to COMP BX were analyzed for metals and selected organic contaminants (pesticides, PCBs, and PAHs), the results of which are summarized in this section. Magnification factors (number of times the test concentration dry weight is elevated above the reference concentration dry weight) are listed and further discussed in 
Section 3.5.9. Complete test results and water quality data are tabulated in Appendix $E$ for both species. Analytical results, including a quality control summary and associated quality control data, are presented in Appendix $F$ for $M$. nasuta and in Appendix $G$ for $N$. virens.

\subsubsection{Bioaccumulation of Metals in Macoma nasuta}

Results of analysis of $M$. nasuta tissues exposed to Bronx River composites and to Mud Dump Reference Site sediment for metals are shown in Table 3.11. All nine metals analyzed were detected in tissues exposed to COMP BX and in the Mud Dump Reference Site. The BX composite produced significantly elevated concentrations of $\mathrm{Cd}, \mathrm{Cr}, \mathrm{Ni}$, and $\mathrm{Pb}$, relative to the Mud Dump Reference Site treatment. The magnification factor, the magnitude by which a contaminant concentration in the test composite tissues exceeds that from the reference composite tissues, was less than five for $\mathrm{Cd}, \mathrm{Cr}, \mathrm{Ni}$ and $\mathrm{Pb}$.

\subsubsection{Bioaccumulation of Chlorinated Pesticides in Macoma nasuta}

Results of analysis of $M$. nasuta tissues exposed to the COMP BX and Mud Dump Reference Site sediment for chlorinated pesticides are shown in Table 3.12. In comparison with tissues exposed to the Mud Dump Reference Site sediment, the BX composite tissues had statistically significantly elevated concentration of 4,4'-DDD, 4,4'-DDE, $\alpha$-chlordane, aldrin, dieldrin, trans-nonachlor, and total DDT. Tissues exposed to COMP BX contained concentrations of all the statistically significantly elevated pesticides at levels that exceeded reference concentrations by a factor of less than 5 times, except $\alpha$-chlordane, which exceeded reference concentrations by a factor of greater than 10 times.

\subsubsection{Bioaccumulation of PCBs in Macoma nasuta}

Results of analysis of $M$. nasuta tissues exposed to COMP BX and Mud Dump Reference Site sediment for PCBs are shown in Table 3.13. Of the 22 PCBs analyzed, 17 were detected in M. nasuta tissues exposed to the Bronx River composite. Eleven PCBs were observed at concentrations that were significantly elevated in Bronx River-exposed tissues relative to those in tissues exposed to the Mud Dump Reference Site sediment. In tissues exposed to COMP BX, the concentrations of PCB 18 exceeded those of the Mud Dump Reference tissues by more than 10 times. COMP BX tissue concentrations of PCBs 8 and 44

BRONX RIVER 
TABLE 3.11 Mean Concentrations of Metals in Macoma nasuta Tissues Exposed to Bronx River Composite and the Mud Dump Reference Site Sediment

\begin{tabular}{llll} 
& \multicolumn{2}{c}{ Concentration $(\mathrm{mg} / \mathrm{kg}$ wet weight) } \\
\cline { 2 - 4 } Analyte & $\underline{\text { MDRS }}^{(\mathrm{b})}$ & $\underline{\mathrm{BX}}$ & $\underline{\mathrm{S}}^{(\mathrm{c})}$ \\
Silver & 0.0770 & 0.0836 & No \\
Arsenic & 4.40 & 4.20 & No \\
Cadmium & 0.0248 & 0.0456 & Yes \\
Chromium & 0.288 & 0.551 & Yes \\
Copper & 2.50 & 3.50 & No \\
Mercury & 0.0149 & 0.0153 & No \\
Nickel & 0.360 & 0.546 & Yes \\
Lead & 0.712 & 2.20 & Yes \\
Zinc & 11.7 & 16.9 & No
\end{tabular}

(a) Results shown are a mean of five replicate tissue analyses.

(b) MDRS Mud Dump Reference Site.

(c) SD Dry weight concentrations significantly different.

TABLE 3.12. Mean Concentrations of Pesticides in Macoma nasuta Tissues Exposed to Bronx River Composite and Mud Dump Reference Site Sediment

\begin{tabular}{|c|c|c|c|}
\hline \multirow[b]{2}{*}{ Analyte } & \multicolumn{3}{|c|}{ Concentration ( $\mu \mathrm{g} / \mathrm{kg}$ wet weight) ${ }^{(a)}$} \\
\hline & MDRS $^{(b)}$ & $\underline{B X}$ & $\underline{S}^{(c)}$ \\
\hline 2,4'-DDD & $0.16 \mathrm{Q}^{(\mathrm{d})}$ & 0.50 & No \\
\hline 2,4'-DDE & $0.17 \mathrm{Q}$ & $0.20 Q$ & No \\
\hline 2,4'-DDT & $0.12 \mathrm{Q}$ & $0.14 Q$ & No \\
\hline 4,4'-DDD & 1.00 & 3.27 & Yes \\
\hline $4,4^{\prime}-\mathrm{DDE}$ & 1.92 & 3.33 & Yes \\
\hline 4,4'-DDT & 0.62 & 1.33 & No \\
\hline$\alpha$-Chlordane & 0.12 & 2.40 & Yes \\
\hline Aldrin & 1.10 & 1.91 & Yes \\
\hline Dieldrin & $0.34 \mathrm{Q}$ & 1.75 & Yes \\
\hline Endosulfan I & $0.12 Q$ & $0.14 Q$ & No \\
\hline Endosulfan II & $0.12 \mathrm{Q}$ & $0.14 \mathrm{Q}$ & No \\
\hline Endosulfan Sulfate & $0.16 \mathrm{Q}$ & $0.19 \mathrm{Q}$ & No \\
\hline Heptachlor & 0.25 & 0.25 & No \\
\hline Heptachlor Epoxide & $0.09 \mathrm{Q}$ & $0.10 \mathrm{Q}$ & No \\
\hline trans-Nonachior & $0.10 Q$ & 0.63 & Yes \\
\hline $\begin{array}{l}\text { Total Estimated DDT } \\
\text { Total Detected DDT }\end{array}$ & $\begin{array}{l}3.99 \\
3.54\end{array}$ & $\begin{array}{l}8.77 \\
8.43\end{array}$ & Yes \\
\hline
\end{tabular}

(a) Results shown are a mean of five replicate tissue analyses. If any constituents were undetected, onehalf of the detection limit was used in calculation of the mean concentration.

(b) MDRS Mud Dump Reference Site.

(c) SD Dry weight concentrations significantly different.

(d) $\mathrm{Q}$ One-half the achieved detection limit.

(e) Total estimated DDT is the sum of 4,4'-DDT, 4,4'-DDE, 4,4'-DDD, 2,4'-DDT, 2,4'-DDE, and 2,4'-DDD. One-half of the detection limit was used in summation when constituent was not detected. 
TABLE 3.13. Mean Concentrations of PCBs in Macoma nasuta Tissues Exposed to Bronx River Composite and Mud Dump Reference Site Sediment

\begin{tabular}{|c|c|c|c|}
\hline \multirow[b]{2}{*}{ Analyte } & \multicolumn{3}{|c|}{ Concentration ( $\mu \mathrm{g} / \mathrm{kg}$ wet weight) ${ }^{(\mathrm{a})}$} \\
\hline & $\mathrm{MDRS}^{(\mathfrak{b})}$ & BX & $\underline{S D^{(c)}}$ \\
\hline PCB 8 & $0.23 Q^{(d)}$ & 3.95 & Yes \\
\hline PCB 18 & $0.07 \mathrm{Q}$ & 7.88 & Yes \\
\hline PCB 28 & 2.31 & 8.67 & Yes \\
\hline РСB 44 & $0.05 Q$ & 0.64 & No \\
\hline PCB 49 & 1.35 & 4.20 & Yes \\
\hline РCB 52 & 1.74 & 6.60 & Yes \\
\hline PCB 66 & 1.77 & 4.73 & Yes \\
\hline РСВ 87 & 0.20 & 0.92 & Yes \\
\hline PCB 101 & 1.44 & 3.94 & Yes \\
\hline PCB 105 & 0.26 & 0.57 & No \\
\hline PCB 118 & 1.00 & 2.28 & Yes \\
\hline PCB 128 & $0.07 Q$ & 0.18 & No \\
\hline PCB 138 & 0.62 & 2.15 & Yes \\
\hline PCB 153 & 0.78 & 2.75 & Yes \\
\hline РСB 170 & $0.12 Q$ & 0.18 & No \\
\hline PCB 180 & $0.25 Q$ & 0.72 & No \\
\hline PCB 183 & $0.12 Q$ & $0.14 Q$ & No \\
\hline PCB 184 & $0.12 Q$ & $0.14 Q$ & No \\
\hline PCB 187 & $0.14 Q$ & 0.33 & No \\
\hline PCB 195 & $0.08 \mathrm{Q}$ & $0.10 \mathrm{Q}$ & No \\
\hline PCB 206 & $0.14 Q$ & $0.16 Q$ & No \\
\hline PCB 209 & $0.13 Q$ & $0.15 Q$ & No \\
\hline Total Estimated $\mathrm{PCB}^{(\mathrm{e})}$ & 26.0 & 103 & \\
\hline Total Detected PCB & 11.5 & 50.7 & \\
\hline
\end{tabular}

(a) Results shown are a mean of five replicate tissue analyses. If any constituents were undetected, one-half of the detection limit was used in calculation of the mean concentration.

(b) MDRS Mud Dump Reference Site.

(c) SD Dry weight concentrations significantly different.

(d) $Q$ One-half the achieved detection limit.

(e) Total estimated PCB $=2(x)$, where $x=$ sum of all 22 PCB congeners; one-half of the detection limit used in summation when analyte was undetected. 
exceeded the reference tissue concentrations by greater than 5 times but less than 10 times. The remaining 19 PCB congeners showed less than 5 times greater concentrations in COMP BX tissue compared with reference tissue.

\subsubsection{Bioaccumulation of PAHs and 1,4-Dichlorobenzene in Macoma nasuta}

Results of analysis of $M$. nasuta tissues exposed to COMP BX and Mud Dump Reference Site sediments for PAHs and 1,4-dichlorobenzene are shown in Table 3.14. Fifteen of the 16 PAHs analyzed were detected in $M$. nasuta tissues exposed to COMP BX at significantly elevated concentrations, relative to tissues exposed to the Mud Dump Reference Site sediment; only naphthalene was not significantly elevated. Five of the 16 PAHs analyzed were found at concentrations over 10 times higher in $M$. nasuta exposed to the $B X$ composite than in the Mud Dump Reference Site sediment. Four of the 16 PAHs analyzed were found at concentrations between 5 and 10 times higher in $M$. nasuta exposed to the COMP BX than in the Mud Dump Reference Site. The remaining 7 PAHs analyzed were found at concentrations less than 5 times higher in $M$. nasuta exposed to COMP BX than in the $M$. nasuta exposed to Mud Dump Reference Site sediment. The compound 1,4-dichlorobenzene was detected in the tissues exposed to the Bronx River at a concentration of $1.88 \mu \mathrm{g} / \mathrm{kg}$ wet weight.

\subsubsection{Bioaccumulation of Metals in Nereis virens}

Results of analysis of $N$. virens tissues exposed to the Bronx River composites and Mud Dump Reference sediment for metals are shown in Table 3.15. All metals analyzed except Ag and $\mathrm{Cr}$ were detected in $N$. virens tissues exposed to COMP BX. None of the metals analyzed was significantly higher in COMP BX-exposed tissues than in Mud Dump Reference Site.

\subsubsection{Bioaccumulation of Chlorinated Pesticides in Nereis virens}

Results of analysis of $N$. virens tissues exposed to the Bronx River composites and Mud Dump Reference Site sediments for chlorinated pesticides are shown in Table 3.16. In comparison with the Mud Dump Reference Site exposed tissues, the BX composite-exposed tissues had statistically significant elevation of 8 of the 15 analyzed pesticides and in total DDT. The compounds 4,4'-DDE and $\alpha$-chlordane exceeded reference tissue concentrations by greater than 10 times in tissues exposed to COMP BX. Four pesticide compounds found in tissues exposed to COMP BX exceeded levels in reference tissues by greater than 5 times, but less than 
TABLE 3.14. Mean Concentrations of PAHs and 1,4-Dichlorobenzene in Macoma nasuta Tissues Exposed to Bronx River Composite and Mud Dump Reference Site Sediment

Analyte

Naphthalene

Acenaphthylene

Acenaphthene

Fluorene

Phenanthrene

Anthracene

Total Estimated LPAH ${ }^{(e)}$

Total Detected LPAH

Fluoranthene

Pyrene

Benz[a]anthracene

Chrysene

Benzo[b]fluoranthene

Benzo[k]fluoranthene

Benzo[a]pyrene

Indeno[123-cd]pyrene

Dibenz[a,h]anthracene

Benzo[g,h,i]perylene

Total Estimated $\mathrm{HPAH}^{(\mathrm{e})}$

Total Detected HPAH

Total Estimated $\mathrm{PAH}^{(\mathrm{e})}$

Total Detected PAH

Concentration ( $\mu \mathrm{g} / \mathrm{kg}$ wet weight) ${ }^{(\mathrm{a})}$

MDRS $^{\left(b^{b}\right)}$

3.45

0.56

$0.89 Q^{(d)}$

1.13

2.10

1.86

9.99

9.10

9.11

23.6

8.48

6.23

15.7

3.07

7.43

1.58

$0.80 \mathrm{Q}$

2.06

78.1

77.3

88.1

86.4

$1.28 Q$
BX

4.53

1.88

4.78

4.91

42.2

23.4

81.7

81.7

\section{1,4-Dichlorobenzene}

(a) Results shown are a mean of five replicate tissue analyses. If any constituents were undetected, one-half of the detection limit was used in calculation of the mean concentration.

(b) MDRS Mud Dump Reference Site.

(c) SD Dry weight concentrations significantly different.

(d) Q One-half the achieved detection limit.

(e) Total estimated values include one-half the detection limit for undetected constituents. 
TABLE 3.15. Mean Concentrations of Metals in Nereis virens Tissues Exposed to Bronx River Composite and the Mud Dump Reference Site Sediment

\begin{tabular}{llll} 
& \multicolumn{2}{c}{ Concentration (mg/kg wet weight) } \\
\cline { 2 - 4 } Analyte & ${\underline{\mathrm{MDRS}^{(\mathrm{b})}}}^{(\mathrm{a})}$ & $\underline{\mathrm{BX}}$ & $\underline{\mathrm{S}}^{(\mathrm{c})}$ \\
Silver & $0.0171 \mathrm{Q}^{(\mathrm{d})}$ & $0.0164 \mathrm{Q}$ & No \\
Arsenic & 3.28 & 2.31 & No \\
Cadmium & 0.0728 & 0.0536 & No \\
Chromium & 0.0379 & $0.0063 \mathrm{Q}$ & No \\
Copper & 1.63 & 1.19 & No \\
Mercury & 0.0257 & 0.0341 & No \\
Nickel & 0.0497 & 0.0683 & No \\
Lead & 0.210 & 0.182 & No \\
Zinc & 8.55 & 7.26 & No
\end{tabular}

(a) Results shown are a mean of five replicate tissue analyses. If any constituents were undetected, onehalf of the detection limit was used in calculation of the mean concentration.

(b) MDRS Mud Dump Reference Site.

(c) SD Dry weight concentrations significantly different.

(d) $Q$ One-half the achieved detection limit.

TABLE 3.16. Mean Concentrations of Pesticides in Nereis virens Tissues Exposed to Bronx River Composite and Mud Dump Reference Site Sediment

Analyte

$2,4^{\prime}-\mathrm{DDD}$

$2,4^{\prime}-$ DDE

$2,4^{\prime}-$ DDT

4,4'-DDD

4,4'-DDE

4,4'-DDT

$\alpha$-Chlordane

Aldrin

Dieldrin

Endosulfan I

Endosulfan II

Endosulfan Sulfate

Heptachlor

Heptachlor Epoxide

trans-Nonachlor

Total Estimated DDT ${ }^{(e)}$

Total Detected DDT
Concentration ( $\mu \mathrm{g} / \mathrm{kg}$ wet weight) ${ }^{(\mathrm{a})}$

\begin{tabular}{lll}
\hline$\underline{M D R S}^{(b)}$ & $\underline{B X}$ & $\underline{S D}^{(c)}$ \\
0.18 & 1.73 & Yes \\
$0.15 Q^{(d)}$ & $0.15 Q$ & No \\
$0.10 \mathrm{Q}$ & $0.10 \mathrm{Q}$ & No \\
1.04 & 5.79 & Yes \\
0.22 & 3.08 & Yes \\
0.78 & 1.88 & Yes \\
0.18 & 3.91 & Yes \\
0.77 & 2.68 & Yes \\
$0.29 \mathrm{Q}$ & 2.88 & Yes \\
$0.10 \mathrm{Q}$ & $0.10 \mathrm{Q}$ & No \\
$0.10 \mathrm{Q}$ & $0.10 \mathrm{Q}$ & No \\
$0.14 \mathrm{Q}$ & $0.14 \mathrm{Q}$ & No \\
0.29 & 0.26 & No \\
$0.07 \mathrm{Q}$ & 0.33 & No \\
0.47 & 2.47 & Yes \\
2.47 & 12.73 & Yes \\
2.22 & 12.48 &
\end{tabular}

(a) Results shown are a mean of five replicate tissue analyses. If any constituents were undetected, onehalf of the detection limit was used in calculation of the mean concentration.

(b) MDRS Mud Dump Reference Site.

(c) SD Dry weight concentrations significantly different.

(d) $Q$ One-half the achieved detection limit.

(e) Total estimated DDT is the sum of 4,4'-DDT, 4,4'-DDE, 4,4'-DDD, 2,4'-DDT, 2,4'-DDE, and 2,4'-DDD. One-half of the detection limit was used in summation when constituent was not detected. 
10 times. The remaining nine pesticide compounds analyzed for in tissues exposed to COMP BX exceeded levels in reference tissues by less than 5 times.

\subsubsection{Bioaccumulation of PCBs in Nereis virens}

Results of analysis of $N$. virens tissues exposed to the Bronx River composites and Mud Dump Reference sediment for PCBs are shown in Table 3.17. There were 16 of the 19 PCBs detected in $N$. virens tissues exposed to COMP BX at concentrations that were significantly elevated relative to those in tissues exposed to the Mud Dump Reference sediment. In COMP BX tissues, 6 PCBs (PCB 18, 28, 44, 49, 66, and 118) were observed at concentrations greater than 10 times those of the tissues exposed to the Mud Dump Reference sediment; 4 PCBs (PCB 52, 101, 105, and 170) were observed at concentrations between 5 and 10 times those exposed to the Mud Dump Reference sediment; and 12 PCBs were observed at less than 5 times those concentrations found in tissues exposed to the Mud Dump Reference sediment.

\subsubsection{Bioaccumulation of PAHs and 1,4-Dichlorobenzene in Nereis virens}

Results of analysis of $N$. virens tissues exposed to the Bronx River composites and Mud Dump Reference Site sediment for PAHs and 1,4-dichlorobenzene are shown in Table 3.18. All PAHs analyzed were detected in tissues exposed to the COMP BX composite, except for dibenz[a,h]anthracene. Nine PAHs in tissues exposed to BX were significantly elevated above PAHs in tissues exposed to the Mud Dump Reference Site. Concentrations of fluoranthene, pyrene, and chrysene were elevated in tissues exposed to $B X$ over concentrations in tissues exposed to the reference sediments by more than 10 times. Benz[a]anthracene and benzo[b]fluoranthene in tissues exposed to COMP BX were observed at concentrations between 5 and 10 times those in tissues exposed to the Mud Dump Reference sediment. The remaining $11 \mathrm{PAHs}$ in tissues exposed to COMP BX were observed to be less than 5 times those found in tissues exposed to the Mud Dump Reference sediment. The compound 1,4-dichlorobenzene was not detected in COMP BX-exposed tissues. 
TABLE 3.17. Mean Concentrations of PCBs in Nereis virens Tissues Exposed to Bronx River Composites and Mud Dump Reference Site Sediment

Concentration ( $\mu \mathrm{g} / \mathrm{kg}$ wet weight) $)^{(a)}$

$\begin{array}{llcl}\text { Analyte } & \text { MDRS }^{(\mathrm{b})} & \text { BX } & \underline{\text { SD }}^{(\mathrm{c})} \\ \text { PCB 8 } & 0.20 \mathrm{Q}^{(\mathrm{d})} & 0.19 \mathrm{Q} & \text { No } \\ \text { PCB 18 } & 0.31 & 10.9 & \text { Yes } \\ \text { PCB 28 } & 0.06 \mathrm{Q} & 6.94 & \text { Yes } \\ \text { PCB 44 } & 0.04 \mathrm{Q} & 5.97 & \text { Yes } \\ \text { PCB 49 } & 0.36 & 5.80 & \text { Yes } \\ \text { PCB 52 } & 1.12 & 9.83 & \text { Yes } \\ \text { PCB 66 } & 0.08 \mathrm{Q} & 2.90 & \text { No } \\ \text { PCB 87 } & 0.14 \mathrm{Q} & 0.70 & \text { Yes } \\ \text { PCB 101 } & 0.96 & 5.55 & \text { Yes } \\ \text { PCB 105 } & 0.20 & 1.63 & \text { Yes } \\ \text { PCB 118 } & 0.23 & 3.30 & \text { Yes } \\ \text { PCB 128 } & 0.19 & 0.67 & \text { Yes } \\ \text { PCB 138 } & 4.70 & \text { Yes } \\ \text { PCB 153 } & 1.21 & 6.33 & \text { Yes } \\ \text { PCB 170 } & 1.72 & 1.40 & \text { Yes } \\ \text { PCB 180 } & 0.24 & 2.74 & \text { Yes } \\ \text { PCB 183 } & 0.56 & 0.79 & \text { Yes } \\ \text { PCB 184 } & 0.12 & 0.10 \mathrm{Q} & \text { No } \\ \text { PCB 187 } & 0.10 \mathrm{Q} & 2.01 & \text { Yes } \\ \text { PCB 195 } & 0.40 & 0.16 & \text { No } \\ \text { PCB 206 } & 0.07 \mathrm{Q} & 0.23 & \text { No } \\ \text { PCB 209 } & 0.12 \mathrm{Q} & 0.11 \mathrm{Q} & \text { No } \\ \text { Total Estimated PCB } & & \\ \text { Total Detected PCB } & 17.1 & 146 & \\ & 7.62 & 72.6 & \end{array}$

(a) Results shown are a mean of five replicate tissue analyses. If any constituents were undetected, one-half of the detection limit was used in calculation of the mean concentration.

(b) MDRS Mud Dump Reference Site.

(c) SD Dry weight concentrations significantly different.

(d) $\mathrm{Q}$ One-half the achieved detection limit.

(e) Total estimated PCB $=2(x)$, where $x=$ sum of all 22 PCB congeners; one-half of the detection limit used in summation when analyte was undetected. 
TABLE 3.18. Mean Concentrations of PAHs and 1,4-Dichlorobenzene in Nereis virens Exposed to Bronx River Composites and Mud Dump Reference Site Sediment Concentration ( $\mu \mathrm{g} / \mathrm{kg}$ wet weight) ${ }^{(\mathrm{a})}$

\begin{tabular}{|c|c|c|c|}
\hline Analyte & ${\underline{M^{\prime}}}^{(b)}$ & BX & $\underline{S^{(c)}}$ \\
\hline Naphthalene & 3.47 & 3.53 & No \\
\hline Acenaphthylene & $0.33 Q^{(d)}$ & 0.95 & No \\
\hline Acenaphthene & 0.90 & 4.51 & Yes \\
\hline Fluorene & 0.87 & 1.51 & No \\
\hline Phenanthrene & $1.48 \mathrm{Q}$ & 5.23 & No \\
\hline Anthracene & $1.25 \mathrm{Q}$ & 1.49 & No \\
\hline Total Estimated LPAHs ${ }^{(e)}$ & 8.30 & 17.2 & \\
\hline Total Detected LPAHs & 5.24 & 17.2 & \\
\hline Fluoranthene & $1.95 \mathrm{Q}$ & 93.7 & Yes \\
\hline Pyrene & 3.75 & 122 & Yes \\
\hline Benzo(a)anthracene & 0.75 & 8.40 & Yes \\
\hline Chrysene & 1.22 & 42.1 & Yes \\
\hline Benzo(b)fluoranthene & $0.69 \mathrm{Q}$ & 9.33 & Yes \\
\hline Benzo(k)fluoranthene & $0.85 Q$ & 4.54 & Yes \\
\hline Benzo(a)pyrene & $0.74 \mathrm{Q}$ & 5.03 & Yes \\
\hline Indeno(123-cd)pyrene & $0.88 Q$ & 1.47 & No \\
\hline Dibenz $(a, h)$ anthracene & $0.68 Q$ & $0.68 Q$ & No \\
\hline Benzo $(g, h, i)$ perylene & $0.63 Q$ & 2.89 & Yes \\
\hline Total Estimated HPAHs ${ }^{(e)}$ & 12.1 & 290 & \\
\hline Total Detected HPAHs & 5.72 & 289 & \\
\hline Total Estimated PAHs $\mathrm{s}^{(\mathrm{e})}$ & 20.4 & 307 & \\
\hline Total Detected PAHs & 11.0 & 306 & \\
\hline 1,4-Dichlorobenzene & $1.10 \mathrm{Q}$ & $1.09 \mathrm{Q}$ & No \\
\hline \multicolumn{4}{|c|}{$\begin{array}{l}\text { (a) Results shown are a mean of five replicate tissue analyses. If any constituents were } \\
\text { undetected, one-half of the detection limit was used in calculation of the mean } \\
\text { concentration. } \\
\text { (b) MDRS Mud Dump Reference Site. } \\
\text { (c) SD Dry weight concentrations significantly different. } \\
\text { (d) Q One-half the achieved detection limit. } \\
\text { (e) Total estimated values include one-half the detection limit for undetected constituents }\end{array}$} \\
\hline
\end{tabular}




\subsubsection{Magnification Factors of Compounds in Macoma nasuta and Nereis virens}

Table 3.19 shows the calculated magnification factors of all compounds analyzed, respective to the organisms $M$. nasuta and $N$. virens. Magnification factors were calculated with the dry weight concentrations of the compounds in the tissues of the bioaccumulation organism. These factors show the magnification of the COMP BX-exposed tissues over the Mud Dump Reference Site-exposed tissues. When all replicate analysis of a compound showed that the compound was undetected, the magnification factor displays the magnification of the COMP-BX exposed tissues above the detection limit of the Mud Dump Reference-Site exposed tissues.

In Table 3.19, magnification factors greater than or equal to 5 but less than 10 appear as underlined values, and magnification factors greater than or equal to 10 appear in bold type.

TABLE 3.19. Magnification Factors of All Analyzed Compounds in Tissues Exposed to Bronx River Composites Compared with Mud Dump Reference Site Sediment

Compound

$\mathrm{Ag}$ (silver)

As (arsenic)

Cd (cadmium)

$\mathrm{Cr}$ (chromium)

Cu (copper)

$\mathrm{Hg}$ (mercury)

Ni (nickel)

$\mathrm{Pb}$ (lead)

Zn (zinc)

2,4'-DDD

2,4'-DDE

2,4'-DDT

4,4'-DDD

$4,4^{\prime}-$ DDE

4,4'-DDT

$\alpha$-Chlordane

Aldrin

Dieldrin

Endosulfan I

Endosulfan II

Endosulfan Sulfate

Heptachlor

Heptachlor Epoxide

trans- Nonachlor
Magnification Factors ${ }^{(a)}$

Macoma nasuta Nereis virens

1.00

0.88

1.00

0.73

1.68

0.77

1.74

1.29

0.94

1.39

2.82

1.31

0.32

0.76

1.37

1.21

0.91

0.88

1.67

1.06

1.05

2.71

1.54

1.94

15.66

1.58

2.34

1.04

1.04

1.05

1.02

1.05

3.06
6.11

1.05

1.04

$\underline{5.70}$

12.27

2.46

22.64

3.60

$\underline{5.18}$

1.04

1.04

1.05

0.89

2.52

$\underline{5.24}$ 
TABLE 3.19. (contd)

Compound

PCB 8

PCB 18

PCB 28

PCB 44

PCB 49

PCB 52

PCB 66

PCB 87

PCB 101

PCB 105

PCB 118

PCB 128

PCB 138

PCB 153

PCB 170

PCB 180

PCB 183

PCB 184

PCB 187

PCB 195

PCB 206

PCB 209

Naphthalene

Acenaphthylene

Acenaphthene

Fluorene

Phenanthrene

Anthracene

Fluoranthene

Pyrene

Benzo(a)anthracene

Chrysene

Benzo(b)fluoranthene

Benzo(k)fluoranthene

Benzo(a)pyrene

Indeno(123-cd)pyrene

Dibenzo(a,h)anthracene

Benzo(g,h,i)perylene
Magnification Factors ${ }^{(a)}$

Macoma nasuta Nereis virens

\begin{tabular}{r}
7.77 \\
\hline 53.16 \\
3.31 \\
6.12 \\
\hline 2.84 \\
3.46 \\
2.42 \\
2.47 \\
2.47 \\
1.78 \\
2.08 \\
1.41 \\
2.86 \\
2.79 \\
1.13 \\
1.46 \\
1.04 \\
1.04 \\
1.56 \\
1.06 \\
1.04 \\
1.05
\end{tabular}

1.29

2.17

2.56

2.71

10.85

7.13

22.95

11.01

12.36

18.42

$\underline{6.23}$

$\underline{5.39}$

7.31

4.44

1.82

4.93

1.04
1.05

30.49

58.39

79.61

15.47

8.99

17.74

2.68

$\underline{5.91}$

$\underline{5.99}$

11.33

3.31

3.92

3.71

$\underline{5.03}$

4.53

4.02

1.07

4.72

1.40

1.26

1.03

1.08

1.63

3.09

1.28

2.06

1.06

24.38

28.41

$\underline{7.97}$

20.82

$\frac{6.98}{2.85}$

3.61

1.23

1.05

2.46

1.05

1,4-Dichlorobenzene

(a) Magnification factors are the number of times the test treatment concentration is greater than the reference treatment concentration. When the compound is undetected the achieved detection limit value is used in the calculation. Calculations are with dry weight concentration values. 


\subsection{Discussion and Conclusions}

In this section, physical and chemical analyses, and bioassays performed on the Bronx River sediment composite are evaluated relative to the Mud Dump Reference Site sediment by the guidelines of the Green Book Tier III. Tier III evaluations include water-column toxicity tests, benthic toxicity tests, and whole-sediment bioaccumulation studies. Tier III evaluations assess the impact of contaminants in the dredged material on marine organisms to determine whether there is potential for the material to have an unacceptable environmental effect during ocean disposal. The Green Book provides the following guidance for determining whether the proposed dredged material is unacceptable for ocean disposal based on the Tier III benthic acute toxicity test:

- Benthic Acute Toxicity. The proposed dredged material does not meet the limiting permissible concentration (LPC) for benthic toxicity when organism survival in the test sediment and the reference site sediment is statistically significantly different, and the decrease in survival exceeds $20 \%$ for $A$. abdita, or $10 \%$ for M. bahia.

- Water-Column Toxicity. The LPC of dissolved plus suspended contaminants cannot exceed 0.01 of the acutely toxic concentration at the boundaries of the disposal site within the first $4 \mathrm{~h}$ after disposal, or at any point in the marine environment after the first $4 \mathrm{~h}$. The acutely toxic concentration in this case is taken to be the median lethal concentration $\left(\mathrm{LC}_{50}\right)$; therefore, at least $50 \%$ mortality in an SPP treatment would be required before acute toxicity could be demonstrated according to the Green Book. A numerical mixing model should be used to predict whether concentrations greater than 0.01 of the acutely toxic SPP concentrations are likely to occur beyond the boundaries of the disposal site within the first $4 \mathrm{~h}$ after disposal.

- Bioaccumulation. The proposed dredged material does not meet the LPC for bioaccumulation if tissue concentrations of one or more contaminants of concern are greater than the applicable FDA levels. Regional guidance (USACE 1981) for interpretation of bioaccumulation was also considered. When the bioaccumulation of contaminants in the dredged material exceeds that in the reference material exposures, further case-specific evaluation criteria listed in the Green Book should be consulted to determine LPC and benthic effects compliance.

Sections 4.1 through 4.4 discuss the proposed Bronx River dredged material in terms of sediment characterization and Tier III evaluations. The matrix in Figure 4.1 summarizes the contribution of the Bronx River sediment composite to water-column or benthic acute toxicity 
and potential for bioaccumulation relative to the Mud Dump Reference Site. This matrix shows bioaccumulation potential as the number of contaminants that were elevated in the tissues of $M$. nasuta and $N$. virens at a range of magnitudes (i.e., 2, 5, or 10 times) above tissues of each species exposed to the reference sediment. This format clearly indicates where similar classes of contaminants were accumulated by both $M$. nasuta and $N$. virens.

\subsection{Sediment Physical and Chemical Characterization}

Bronx River sediment core samples were generally black, silty-clayey material. The grain-size distributions of core samples were variable. Two stations were predominantly sand and gravel ( $\mathrm{BX}-11$ and $\mathrm{BX}-15)$, whereas the remaining 13 stations were predominantly silt and clay. Sediment moisture contents ranged from $20 \%$ to $72 \%$ in individual cores. All nine metals analyzed in COMP BX sediments were detected. The dominant pesticides found in COMP BX were the DDT family of compounds (158 $\mu \mathrm{g} / \mathrm{kg}$ total DDT), followed by $\alpha$-chlordane, transnonachlor, aldrin, and endosulfan sulfate. Eighteen of the 22 PCB congeners analyzed were detected in COMP BX sediment, with a total estimated PCB concentration was calculated as $1660 \mu \mathrm{g} / \mathrm{kg}$. All 16 PAHs analyzed were detected in COMP BX sediment. In COMP BX, LPAH $(7410 \mu \mathrm{g} / \mathrm{kg})$ made up approximately $16 \%$ of the total PAH concentration $(45,800 \mu \mathrm{g} / \mathrm{kg}$ dry weight). The concentration of 1,4-dichlorobenzene was $249 \mu \mathrm{g} / \mathrm{kg}$ (dry weight) in COMP BX.

\subsection{Site Water and Elutriate Chemical Characterization}

Concentrations of metals in Bronx River elutriate were similar to, but generally less than Bronx River site water concentrations. Most pesticides and PCBs were not detected in the site water. The majority of pesticides and PCB congeners detected were in the elutriate samples.

\subsection{Toxicity}

In comparison with the Mud Dump Reference Site, statistically significant acute toxicity and greater than $20 \%$ increase in mortality was found with the Bronx River composite in the static-renewal test with A. abdita. In comparison with the Mud Dump Reference Site, no statistically significant acute toxicity or greater than $10 \%$ increase in mortality was found with the Bronx River composite in the static test with $M$. bahia. Therefore, the Bronx River sediment 
composite did not meet the LPC for benthic toxicity to the test organism A. abdita, but the LPC was met for the test organism M. bahia, if the observed effects were due to persistent contaminants.

The 100\% SPP treatments from COMP BX were acutely toxic to all three species tested. For COMP BX, the $\mathrm{LC}_{50}$ s ranged from $21.5 \%$ SPP for $M$. beryllina to $>100 \%$ SPP for M. galloprovincialis. The $\mathrm{EC}_{50}$ for $M$. galloprovincialis normal development, a more sensitive measure than survival, was $23.6 \%$ SPP for COMP BX. Based on acute mortality results $\left(L_{50} s\right)$, the LPC for water-column effects outside of the disposal site boundaries after $4 \mathrm{~h}$ is $0.22 \%$ SPP for COMP BX. A projection of SPP concentrations exceeding this value after $4 \mathrm{~h}$ at the Mud Dump Site boundary would be unacceptable.

\subsection{Bioaccumulation}

Results of $N$. virens and $M$. nasuta tissue analyses from test sediment bioaccumulation studies were compared with action levels for poisonous or deleterious substances in fish and shellfish for human consumption published by the U.S. Food and Drug Administration (FDA). Concentrations of $\mathrm{As}, \mathrm{Cd}, \mathrm{Cr}, \mathrm{Ni}$, and $\mathrm{Pb}$ were also compared with the FDA level of concern for chronic shellfish consumption (FDA 1993a,b,c,d,e) for each of these metals. Results of tissue analyses from test sediment bioaccumulation studies were also compared with contaminant concentrations in tissues of organisms similarly exposed to Mud Dump Reference Site sediment.

When $M$. nasuta and $N$. virens were exposed to COMP BX sediment composite in 28-day bioaccumulation tests, concentrations of some contaminants were elevated in tissues of both species relative to levels in organisms exposed to the Mud Dump Reference Site. Concentrations of all metals were higher in $M$. nasuta than in $N$. virens tissues. Pesticide and PCB concentrations were generally higher in $N$. virens than in $M$. nasuta tissues.

Concentrations of PAHs were higher in M. nasuta, many compounds by factors of 2 to 10 times, than in $N$. virens tissues. Table 4.1 compares the FDA action levels for poisonous or deleterious substances in fish and shellfish for human consumption for selected pesticides and FDA levels of concern for chronic shellfish consumption for selected metals with the mean 
concentration of these contaminants found in tissues of each test species. The $M$. nasuta and $N$. virens tissues exposed to COMP BX sediment had tissue body burdens that were lower than the FDA levels for each of these selected contaminants, except lead in $M$. nasuta tissues which, was slightly higher than the FDA level of concern.

When tissue burdens of $M$. nasuta exposed to COMP BX sediment were compared with those of $M$. nasuta exposed to Mud Dump Reference Site sediment, the tissue burdens were statistically significantly higher for 4 metals, 6 pesticides, 11 PCBs, and 15 PAHs. Comparison of tissue burdens of $N$. virens exposed to COMP BX sediment with those exposed to Mud Dump Reference Site sediment revealed that the tissue burdens were statistically significantly higher for no metals, 8 pesticides, $16 \mathrm{PCBs}$, and $9 \mathrm{PAHs}$. Therefore, COMP BX-A sediment requires further evaluation to determine LPC and benthic effects compliance. Figure 4.1 indicates the number of compounds in each contaminant group that was statistically significantly elevated, and whether the bioaccumulation was greater than a twofold, but less than fivefold increase over the reference; greater than fivefold, but less than tenfold increase over the reference; or a greater than tenfold increase over the reference site treatment. 
TABLE 4.1. Comparison of Contaminant Concentrations in Macoma nasuta and Nereis virens Tissues Exposed to Proposed Dredged Material from Bronx River Project Area with FDA Action Levels and Levels of Concern

\begin{tabular}{|c|c|c|c|}
\hline & & $\begin{array}{c}\text { Concentrations }{ }^{(a)} \\
\text { in } M . \text { nasuta Tissues } \\
\text { (mg/kg wet wt) }\end{array}$ & $\begin{array}{l}\text { Concentrations }^{(a)} \\
\text { in N. virens Tissues } \\
\text { (mg/kg wet wt) }\end{array}$ \\
\hline Substance & $\begin{array}{c}\text { FDA Level } \\
\text { (mg/kg wet wt) }\end{array}$ & COMP BX & COMP BX \\
\hline Chlordane & $0.3^{(b)}$ & $0.0024^{(c)}$ & $0.0039^{(c)}$ \\
\hline$D D T+D D E^{(d)}$ & $5.0^{(\mathrm{b})}$ & 0.009 & 0.013 \\
\hline $\begin{array}{l}\text { Dieldrin + Aldrin } \\
\text { Heptachlor+ }\end{array}$ & $0.3^{(b)}$ & 0.004 & 0.006 \\
\hline Heptachlor epoxide & $0.3^{(b)}$ & 0.0004 & 0.0006 \\
\hline Total PCBs ${ }^{(e)}$ & $2.0^{(b)}$ & 0.051 & 0.073 \\
\hline Arsenic & $86^{(f)}$ & 4.20 & 2.31 \\
\hline Cadmium & $3.7^{(1)}$ & 0.0456 & 0.0536 \\
\hline Chromium & $13^{(i)}$ & 0.551 & $0.0063 \mathrm{Q}^{(\mathrm{g})}$ \\
\hline Lead & $1.7^{(1)}$ & 2.20 & 0.182 \\
\hline Nickel & $80^{(n)}$ & 0.546 & 0.0683 \\
\hline Methyl Mercury & $1.0^{(b)}$ & $0.0153^{(n)}$ & $0.0341^{(h)}$ \\
\hline Total DDT ${ }^{(d)}$ & $0.04^{(i)}$ & 0.009 & 0.013 \\
\hline Total PCB ${ }^{(\mathrm{e})}$ & $0.40^{(i)}$ & NA & 0.073 \\
\hline Total PCB ${ }^{(e)}$ & $0.10^{(i)}$ & 0.051 & NA \\
\hline Mercury (total) & $0.20^{(i)}$ & 0.0153 & 0.0341 \\
\hline Cadmium & $0.30^{(i)}$ & 0.0456 & 0.0536 \\
\hline
\end{tabular}

(a) Results shown are a mean of five replicate tissue analyses. If any constituents were undetected, one-half of the detection limit was used in calculation of the mean concentration.

(b) FDA Action Levels for Poisonous and Deleterious Substances in Fish and Shellfish for Human Food.

(c) Sum of mean values for 2,4'-DDT, 4,4'-DDT, 2,4'-DDE, and 4,4'-DDE. One-half of the detection limit was used in the summation when mean values were undetected.

(d) Sum of mean values for 2,4'-DDT, 4,4'-DDT, 2,4'-DDE, 4,4'-DDE, 2,4'-DDD, 4,4'-DDD. One-half of the detection limit was used in the summation when mean values were undetected.

(e) Total PCBs estimated as $2.0 x$ sum of 22 congeners. One-half of the detection limit was used in the summation when mean values were undetected in a replicate.

(f) FDA Level of concern for chronic shellfish consumption.

(g) Neither compound detected; value presented is 1/2 detection limit.

(h) Value reported here is for total mercury.

(i) USACE-NYD bioaccumulation matrix value designated in 1981 (USACE-NYD 1981). 


\begin{tabular}{|c|c|c|c|}
\hline & $\begin{array}{l}\text { Sediment } \\
\text { Treatment: }\end{array}$ & $\begin{array}{l}\text { Bronx River } \\
\text { vs. MDRS }\end{array}$ \\
\hline \multirow{5}{*}{ 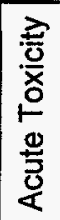 } & \multicolumn{2}{|c|}{ A. abdita Benthic Static-Renewal Test } & $S^{(a)}$ \\
\hline & \multicolumn{2}{|c|}{ M. bahia Benthic Static Test } & $-(\mathrm{b})$ \\
\hline & \multicolumn{2}{|c|}{ M. beryllina SPP Test } & $\mathrm{s}$ \\
\hline & \multicolumn{2}{|c|}{ M. bahia SPP Test } & $\bar{s}$ \\
\hline & \multicolumn{2}{|c|}{ M. galloprovinciallis SPP Test } & $\mathrm{s}$ \\
\hline
\end{tabular}

\begin{tabular}{|c|c|c|c|}
\hline & Test Species ${ }^{(c)}$ : & M.nasuta & N. virens \\
\hline \multirow{5}{*}{ 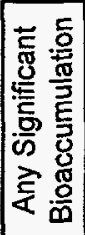 } & \# of Metals ( 9 total) & 4 & - \\
\hline & \# of Pesticide compounds (15 total) & 6 & 8 \\
\hline & \# of PCB congeners (22 total) & 11 & 16 \\
\hline & \# of PAH compounds (16 total) & 15 & 9 \\
\hline & 1,4-dichlorobenzene & - & - \\
\hline
\end{tabular}

\begin{tabular}{|c|c|c|c|}
\hline \multirow{5}{*}{$\mathbb{\sigma}_{\sigma}$} & \# of Metals ( 9 total) & 3 & - \\
\hline & \# of Pesticide compounds (15 total) & 2 & - \\
\hline & \# of PCB congeners (22 total) & - & - \\
\hline & \# of PAH compounds (16 total) & 1 & - \\
\hline & 1,4-dichlorobenzene & - & - \\
\hline
\end{tabular}

\begin{tabular}{|c|c|c|c|}
\hline \multirow{5}{*}{ 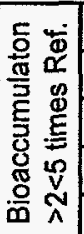 } & \# of Metals ( 9 total) & 1 & - \\
\hline & \# of Pesticide compounds (15 total) & 3 & 2 \\
\hline & \# of PCB congeners ( 22 total) & 9 & 7 \\
\hline & \# of PAH compounds (16 total) & 5 & 4 \\
\hline & 1,4-dichlorobenzene & - & - \\
\hline
\end{tabular}

\begin{tabular}{|c|c|c|c|}
\hline & \# of Metals (9 total) & - & - \\
\hline & \# of Pesticide compounds (15 total) & - & 4 \\
\hline & \# of PCB congeners (22 total) & 1 & 4 \\
\hline & $\#$ of PAH compounds ( 16 total) & 4 & 2 \\
\hline & 1,4-dichlorobenzene & - & - \\
\hline
\end{tabular}

\begin{tabular}{|c|c|c|c|}
\hline & \# of Metals (9 total) & - & - \\
\hline & \# of Pesticide compounds (15 total) & 1 & 2 \\
\hline & \# of PCB congeners (22 total) & 1 & 5 \\
\hline & \# of PAH compounds ( 16 total) & 5 & 3 \\
\hline & 1,4-dichlorobenzene & - & - \\
\hline
\end{tabular}

(a) S Significantly different survival from reference; for amphipods mortality $>\mathbf{2 0 \%}$ greater than reference; for mysids mortality $>10 \%$ greater than reference.

(b) - No significant difference/no significant bioaccumulation at this level.

(c) Number of compounds bioaccumulating in tissues of test species.

FIGURE 4.1. Summary Matrix of Bronx River Sediment Toxicity and Bioaccumulation in Comparison with the Mud Dump Reference Site 


\subsection{References}

Barrows, E.S., M.R. Pinza, W.W. Gardiner, N.P. Kohn, B.D. Gruendell, H.L. Mayhew, J.Q. Word, and L.B. Rosman. 1996. Evaluation of Dredged Material Proposed for Ocean Disposal from Federal Projects in New York and New Jersey and the Military Ocean Terminal (MOTBY). Prepared for Department of the Army, U.S. Army Corps of Engineers, New York District, Water Quality Branch by Battelle Marine Sciences Laboratory, Pacific Northwest National Laboratory, Richland Washington.

Bloom, N.S., and E.A. Crecelius. 1983. "Determination of Mercury in Seawater at SubNanogram per Liter Levels." Mar. Chem. 14:49-59.

Dunnett, C.W. 1964. "New Tables for Multiple Comparisons with a Control." Biometrics 20:482-491.

EPA (U.S. Environmental Protection Agency). 1986. Determination of Total Organic Carbon in Sediment. U.S. Environmental Protection Agency, Region II, Environmental Services Division, Monitoring Management Branch, Edison, New Jersey.

EPA (U.S. Environmental Protection Agency). 1990. Test Methods for Evaluating Solid Waste, Physical/Chemical Methods, SW-846. 3rd Ed. U.S. Environmental Protection Agency, Washington, D.C.

EPA (U.S. Environmental Protection Agency). 1991. Methods for the Determination of Metals in Environmental Samples. EPA/600/4-91-010. U.S. Environmental Protection Agency, Office of Research and Development, Washington, D.C.

EPA (U.S. Environmental Protection Agency). 1994a. Methods for Assessing the Toxicity of Sediment-associated Contaminants with Estuarine and Marine Amphipods. EPAV600/R-94-025 U.S. Environmental Protection Agency, Office of Research and Development, Washington, D.C.

EPA (U.S. Environmental Protection Agency) 1994b. Memorandum: Recommendations for Conducting Sediment Toxicity Test with Mysidopsis bahia when Ammonia may be Present at Toxic Levels. June 14, 1994. U.S. Environmental Protection Agency, Office of Science and Technology, Washington, D.C.

EPAVUSACE (U.S. Environmental Protection Agency/U.S. Army Corps of Engineers). 1991. Evaluation of Dredged Material Proposed for Ocean Disposal (Testing Manual). EPA-503/891/001. U.S. Environmental Protection Agency, Office of Marine and Estuarine Protection, Washington, D.C.

FDA (U.S. Food and Drug Administration). 1993a. Guidance Document for Arsenic in Shellfish. U.S. Food and Drug Administration, Center for Food Safety and Applied Nutrition, Washington, D.C. 
FDA (U.S. Food and Drug Administration). 1993b. Guidance Document for Cadmium in Shellfish. U.S. Food and Drug Administration, Center for Food Safety and Applied Nutrition, Washington, D.C.

FDA (U.S. Food and Drug Administration). 1993c. Guidance Document for Chromium in Shellfish. U.S. Food and Drug Administration, Center for Food Safety and Applied Nutrition, Washington, D.C.

FDA (U.S. Food and Drug Administration). 1993d. Guidance Document for Nickel in Shellfish. U.S. Food and Drug Administration, Center for Food Safety and Applied Nutrition, Washington, D.C.

FDA (U.S. Food and Drug Administration). 1993e. Guidance Document for Lead in Shellfish. U.S. Food and Drug Administration, Center for Food Safety and Applied Nutrition, Washington, D.C.

Finney, D. J. 1971. Probit Analysis. 3rd Ed. Cambridge University Press, Boston, Massachusetts.

NOAA (National Oceanic and Atmospheric Administration). 1993. Sampling and Analytical Methods of the National Status and Trends Program National Benthic Surveillance and Mussel Watch Projects 1984-1992. Volume IV. Comprehensive Descriptions of Trace Organic Analytical Methods. G. G. Lauenstein and A.Y. Cantillo, eds. NOAA Technical Memorandum NOS ORCA 71. National Oceanic and Atmospheric Administration, Coastal Monitoring and Bioeffects Assessment Division, Office of Ocean Resources Conservation and Assessment, Silver Spring, Maryland.

NYSDEC (New York State Department of Environmental Conservation). 1992. Analytical Method for the Determination of PCB congeners by Fused Silica Capillary Column Gas Chromatography with Electron Capture Detector. NYSDEC Method 91-11. New York State Department of Environmental Conservation, Albany, New York.

Plumb, R. H., Jr. 1981. Procedure for Handling and Chemical Analysis of Sediment and Water Samples. Tech. Rep. EPAJUSACE-81-1. Prepared by Great Lakes Laboratory, State University College at Buffalo, New York, for the U.S. Environmental Protection Agency/U.S. Army Corps of Engineers Technical Committee on Criteria for Dredged and Fill Material. U.S. Army Engineer Waterways Experiment Station, Vicksburg, Mississippi.

USACE (U.S. Army Corps of Engineers). 1970 (Revised 1980). Engineer Manual, Engineering and Design, Laboratory Soils Testing. EM 110-2-1906. Headquarters, Department of the Army, Office of the Chief of Engineers, Washington, D.C.

USACE-NYD (U.S. Army Corps of Engineers, New York District) 1981. Memorandum: Final Interpretive Guidance for Bioaccumulation of Petroleum Hydrocarbons, DDT, Cadmium, and Mercury in the New York Bight. April 7, 1981. U.S. Army Corps of Engineers, Office of the Chief of Engineers, New York, New York. 
USACE-NYD/EPA Region II (U.S. Army Corps of Engineers, New York District/U.S. Environmental Protection Agency, Region II). 1992. Guidance for Performing Tests on Dredged Material Proposed for Ocean Disposal. 18 December 1992 Draft. U.S. Army Corps of Engineers, New York District and U.S. Environmental Protection Agency, Region II. New York, New York. 



\section{Appendix A}

Sediment Physical/Chemical Analyses and Quality Assurance/Quality Control Data for Bronx River Project 


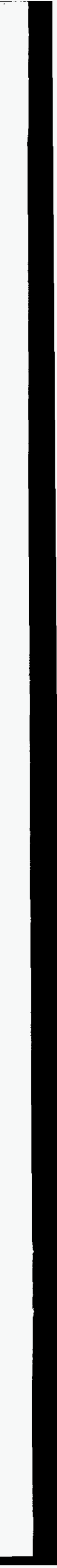


QA/QC SUMMARY

PROGRAM: $\quad$ New York Federal Projects 5

PARAMETER: Grain Size, Bulk Density, Specific Gravity, and Total Solids

LABORATORY: Soil Technology, Bainbridge Island, Washington

MATRIX: $\quad$ Sediment

QA/QC DATA QUALITY OBJECTIVES

\begin{tabular}{|c|c|c|c|}
\hline & $\begin{array}{c}\text { Reference } \\
\text { Method }\end{array}$ & $\begin{array}{c}\text { Target } \\
\text { Relative } \\
\text { Precision } \\
\end{array}$ & $\begin{array}{c}\text { Detection } \\
\text { Limit } \\
\end{array}$ \\
\hline Grain Size & $\begin{array}{l}\text { ASTM D-2217 } \\
\& \text { D-422 }\end{array}$ & $\leq 20 \%$ & $1.0 \%$ \\
\hline Bulk Density & ASTM-D854 & $\leq 20 \%$ & NA \\
\hline Specific Gravity & $E M-1110-2-1906$ & $\leq 20 \%$ & NA \\
\hline Total Solids & Plumb 1981 & NA & $1.0 \%$ \\
\hline
\end{tabular}

METHOD

Grain size was measured for four fractions using a combination of sieve and pipet techniques, following ASTM method D-2217 and D-422 for wet sieving. Bulk density was measured in accordance with ASTM method D-854. Specific gravity was measured in accordance with Method EM 1110-2-1906 (USACE 1970). Total solids was measured gravimetrically following Plumb (1981).

HOLDING TIMES Samples were analyzed within the 6-month holding time.

DETECTION LIMITS Target detection limits of $1.0 \%$ were met for each sample.

METHOD BLANKS Not applicable.

MATRIX SPIKES Not applicable.

REPLICATES Four samples were analyzed in triplicate for grain size and total solids. Precision was measured by calculating the relative standard deviation (RSD) among triplicate results. The RSDs ranged from $0 \%$ to $10 \%$ for grain size and was $0 \%$ for total solids, indicating acceptable precision. 


\section{QAIQC SUMMARY GRAIN SIZE (contd)}

One sample was analyzed in triplicate for bulk density and specific gravity. The RSDs for the bulk density triplicates was $0 \%$ for wet weight determination and $2 \%$ for dry weight determination. The RSD for the specific gravity determination was $0 \%$. Precision for both of these analyses was acceptable.

SRM

Not applicable.

\section{REFERENCES}

ASTM D-2217. Standard Method for Wet Preparation of Soil Samples for Particle-size Analysis and Determination of Soil Constants.

ASTM D-422. Standard Method for Particle-size Analysis of Soils

ASTM D-854. Standard Method for Specific Gravity

USACE (U.S. Army Corps of Engineers). 1970. Engineering and Design Laboratory Soils Testing. EM-1110-2-1906, Vicksburg, Mississippi.

Plumb, R. H., Jr. 1981. Procedure for Handling and Chemical Analysis of Sediment and Water Samples. Tech. Rep. EPAUUSACE-81-1. Prepared by Great Lakes Laboratory, State University College at Buffalo, New York, for the U.S. Environmental Protection Agency/U.S. Army Corps of Engineers Technical Committee on Criteria for Dredged and Fill Materiaí. U.S. Army Engineer Waterways Experiment Station, Vicksburg, Mississippi. 


\section{QA/QC SUMMARY}

PROGRAM: $\quad$ New York Federal Projects 5

PARAMETER: Total Organic Carbon

LABORATORY: $\quad$ Applied Marine Sciences, Inc., College Station, Texas

MATRIX: Sediment

QA/QC DATA QUALITY OBJECTIVES

\begin{tabular}{lccc}
$\begin{array}{c}\text { Reference } \\
\text { Method }\end{array}$ & $\begin{array}{c}\text { Range of } \\
\text { Recovery }\end{array}$ & $\begin{array}{c}\text { Target } \\
\text { Relative } \\
\text { Precision }\end{array}$ & $\begin{array}{c}\text { Detection } \\
\text { Limit (\%) }\end{array}$ \\
\cline { 1 - 4 } EPA 1986 & $\leq 20 \%$ & $\underline{510 \%}$ & 0.1
\end{tabular}

METHOD Total organic carbon is the amount of non-volatile, partially volatile, volatile, and particulate organic carbon compounds in a sample. Each sample was dried and ball milled to a fine powder. Before combustion, inorganic carbon in the sample was removed by acidification. The TOC was then determined by measuring the carbon dioxide released during combustion of the sample.

HOLDING TIMES The holding time of 6 months was met for all TOC analyses.

DETECTION LIMITS Target detection limits of $0.1 \%$ were met for all samples.

METHOD BLANKS Not applicable.

MATRIX SPIKES Not applicable.

REPLICATES Three samples were analyzed in triplicate. Precision was measured by calculating the relative standard deviation (RSD) among the triplicate results. RSDs were $0 \%$ and $2 \%$, indicating acceptable precision.

SRMs

The standard reference material 1941a was analyzed with each batch of analytical samples. The non-certified value for this SRM is $4.8 \pm 1.2$. The SRM values obtained in each analytical batch were within this range.

\section{REFERENCES}

U.S. Environmental Protection Agency (EPA). 1986. Determination of Total Organic Carbon in Sediment. U.S. EPA Region II, Environmental Services Division, Monitoring Management Branch, Edison, New Jersey. 


\section{QA/QC SUMMARY}

PROGRAM: $\quad$ New York/Federal Projects 5

PARAMETER: $\quad$ Metals

LABORATORY: Battelle/Marine Sciences Laboratory, Sequim, Washington

MATRIX: $\quad$ Sediment

QAVQC DATA QUALITY OBJECTIVES

\begin{tabular}{|c|c|c|c|c|c|}
\hline & $\begin{array}{c}\text { Reference } \\
\text { Method } \\
\end{array}$ & $\begin{array}{l}\text { Range of } \\
\text { Recovery }\end{array}$ & $\begin{array}{c}\text { SRM } \\
\text { Accuracy }\end{array}$ & $\begin{array}{l}\text { Relative } \\
\text { Precision }\end{array}$ & $\begin{array}{c}\text { Target } \\
\text { Detection } \\
\text { Limit (dry wt }\end{array}$ \\
\hline Arsenic & ICP/MS & $75-125 \%$ & $\leq 20 \%$ & $\leq 20 \%$ & $0.1 \mathrm{mg} / \mathrm{kg}$ \\
\hline Cadmium & ICP/MS & $75-125 \%$ & $\leq 20 \%$ & $\leq 20 \%$ & $0.01 \mathrm{mg} / \mathrm{kg}$ \\
\hline Chromium & ICP/MS & $75-125 \%$ & $\leq 20 \%$ & $\leq 20 \%$ & $0.02 \mathrm{mg} / \mathrm{kg}$ \\
\hline Copper & ICP/MS & $75-125 \%$ & $\leq 20 \%$ & $\leq 20 \%$ & $0.1 \mathrm{mg} / \mathrm{kg}$ \\
\hline Lead & ICP/MS & $75-125 \%$ & $\leq 20 \%$ & $\leq 20 \%$ & $0.1 \mathrm{mg} / \mathrm{kg}$ \\
\hline Mercury & CVAA & $75-125 \%$ & $\leq 20 \%$ & $\leq 20 \%$ & $0.02 \mathrm{mg} / \mathrm{kg}$ \\
\hline Nickel & ICP/MS & $75-125 \%$ & $\leq 20 \%$ & $\leq 20 \%$ & $0.1 \mathrm{mg} / \mathrm{kg}$ \\
\hline Silver & GFAA & $75-125 \%$ & $\leq 20 \%$ & $\leq 20 \%$ & $0.1 \mathrm{mg} / \mathrm{kg}$ \\
\hline Zinc & ICP/MS & $75-125 \%$ & $\leq 20 \%$ & $\leq 20 \%$ & $0.1 \mathrm{mg} / \mathrm{kg}$ \\
\hline
\end{tabular}

METHOD

Nine metals were analyzed: silver (Ag), arsenic (As), cadmium (Cd), chromium ( $\mathrm{Cr})$, copper $(\mathrm{Cu})$, mercury $(\mathrm{Hg})$, nickel $(\mathrm{Ni})$, lead $(\mathrm{Pb})$ and zinc $(\mathrm{Zn})$. Hg was analyzed using cold-vapor atomic absorption spectroscopy (CVAA) according to the method of Bloom and Crecelius (1983). Ag was analyzed using graphite furnace atomic absorption (GFAA) following a modified EPA Method 200.9 (EPA 1991). The remaining metals were analyzed by inductively coupled plasma mass spectrometry (ICP/MS) following EPA Method 200.8 (EPA 1991).

To prepare sediment samples for analysis, samples were freeze-dried and blended in a Spex mixer-mill. Approximately $5 \mathrm{~g}$ of mixed sample was ground in a ceramic ball mill. For ICP/MS and CVAA analyses, 0.2 - to $0.5-\mathrm{g}$ aliquots of dried homogenous sample were digested using hot nitric acid following a modified version of EPA Method 200.2 (EPA 1991). The modification involved precluding the addition of hydrochloric acid during digestion to avoid interferences caused by the formation of argon chloride in the ICP/MS. ArCl interferes with the quantitation of As, which has the same mass. 


\section{QAIQC SUMMARYIMETALS (continued)}

HOLDING TIMES

DETECTION LIMITS

METHOD BLANKS

MATRIX SPIKES

REPLICATES
Samples were received on 5/30/95 and entered into Battelle's log-in system. Samples were subsequently freeze dried (frozen to $-80^{\circ} \mathrm{C}$ ). Samples were all analyzed within 180 days of collection. The following list summarizes all analysis dates:

$\begin{array}{ll}\text { Task } & \text { Date Performed } \\ \text { Nitric Digestion } & 6 / 21 / 95 \\ \text { ICP-MS } & 8 / 31 / 95 \\ \text { CVAA-Hg } & 6 / 23 / 95 \\ \text { GFAA-Ag } & 7 / 10 / 95\end{array}$

Target detection limits were exceeded for some metals; however, metals were detected above the method detection limits (MDLs) in all samples. MDLs were determined by multiplying the standard deviation of the results of a minimum of seven replicate, low-level sediment spikes by the student's $t$-value at the 99th percentile $(t=3.142)$.

One method blank was included in the analysis. $\mathrm{Ag}, \mathrm{Cd}, \mathrm{Cr}$, and $\mathrm{Hg}$ were detected above the MDL in the blank. Because all blank values were less than three times the MDL and all sample values were detected at greater than five times the blank concentration, no data were flagged. Data were blank corrected.

One sample was spiked with all nine metals. Recoveries of all metals were within the QC limits of $75 \%-125 \%$ with the exception of $\mathrm{Pb}$, which was recovered at $130 \%$ of the spiked concentration. This high spike recovery for $\mathrm{Pb}$ was most likely due to one of five replicate values which was $23 \%$ higher than the other four replicates. Thus, reported values for $\mathrm{Pb}$ were considered accurate.

One sample was digested and analyzed in triplicate. Precision for triplicate analyses is reported by calculating the relative standard deviation (RSD) between the replicate results. RSD values ranged from $1 \%$ to $10 \%$, within the QC limits of $\pm 20 \%$, with the exception of $\mathrm{Pb}$ which had an RSD of $26 \%$. Two of the three replicate values for this sample were similar with the third replicate low. No apparent analytical cause was evident.

Five replicate analyses were performed for the SRM. The Pb RSD was $10 \%$ for these five replicates. Thus, the analytical precision was considered acceptable for $\mathrm{Pb}$. 


\section{QAIQC SUMMARYIMETALS (continued)}

SRM

SRM 1646, an estuarine sediment obtained from the National Institute of Standards and Technology (NIST), was analyzed for all metals. Results for $\mathrm{Cd}, \mathrm{Cu}, \mathrm{Pb}$ and $\mathrm{Hg}$ were within $\pm 20 \%$ of the certified value ( $\mathrm{Ag}$ is not certified). Values for the remaining metals were low because the digestion method used is not as strong as the method (perchloric and hydroflouric acids) used to certify the SRM. Thus, the results for this analysis should not be expected to match the SRM certified values and no corrective actions were taken.

\section{REFERENCES}

Bloom, N. S., and E.A. Crecelius. 1983. "Determination of Mercury in Seawater at SubNanogram per Liter Levels". Mar. Chem. 14:49-59.

EPA (U.S. Environmental Protection Agency). 1991. Methods for the Determination of Metals in Environmental Samples. EPA-600/4-91-010. U.S. Environmental Protection Agency, Environmental Services Division, Monitoring Management Branch, Edison New Jersey. 
QA/QC SUMMARY

PROGRAM: $\quad$ New York/Federal Projects 5

PARAMETER: $\quad$ PCB Congeners/Chlorinated Pesticides

LABORATORY: Battelle/Marine Sciences Laboratory, Sequim, Washington

MATRIX: Sediment

QA/QC DATA QUALITY OBJECTIVES

\begin{tabular}{ccccc}
$\begin{array}{c}\text { Reference } \\
\text { Method }\end{array}$ & $\begin{array}{l}\text { Surrogate } \\
\text { Recovery }\end{array}$ & $\begin{array}{c}\text { Spike } \\
\text { Recovery }\end{array}$ & $\begin{array}{l}\text { Relative } \\
\text { Precision }\end{array}$ & $\begin{array}{c}\text { Target } \\
\text { Detection } \\
\text { Limit (dry wt) }\end{array}$ \\
\cline { 1 - 1 } GC/ECD & $30-150 \%$ & $50-120 \%$ & $\leq 30 \%$ & $1.0 \mu \mathrm{g} / \mathrm{kg}$
\end{tabular}

METHOD

HOLDING TIMES

DETECTION LIMITS

METHOD BLANKS
A 20 gram (wet wt) aliquot of sediment samples were extracted and analyzed according to a procedure similar to EPA Method 8080 for pesticides and the New York State Department of Environmental Conservation (NYSDEC) Congener-Specific Method 91-11 (NYSDEC 1992) for PCB analysis. Sediment was first combined with sodium sulfate in a sample jar to remove water. Samples were extracted by adding successive portions of methylene chloride and agitating sample jars at ambient temperature using a roller technique. Extract volumes were reduced and solvent-exchanged to hexane, followed by Florisil-column chromatography cleanup. Interferences were removed using HPLC cleanup. Sample extracts were concentrated and analyzed using GC-ECD by the internal standard technique. The column used was a J\&W DB-17 and the confirmatory column was a DB-1701, both capillary columns ( $30 \mathrm{~m} \times 0.25 \mathrm{~mm}$ I.D.).

Samples were received on 5/30/95 and entered into Battelle's log-in system. Samples were stored frozen at approximately $-20^{\circ} \mathrm{C}$ until extraction. Samples were extracted on 6/22/95. Extracts were analyzed by GC/ECD from 7/13-14/95, within the established holding time of 40 days.

Target detection limits were met for all PCBs and pesticides. Method detection limits (MDLs) were determined by multiplying the standard deviation of seven spiked replicates of a representative clean marine sediment by the student's $t$-value $(t=3.142)$.

One method blank was extracted. No PCB congeners or pesticides were detected above the MDL in the method blank. 


\section{QA/QC SUMMARY/PCB CONGENERS/PESTICIDES (continued)}

\section{SURROGATES}

MATRIX SPIKES

REPLICATES

SRMs

MISCELLANEOUS
Two compounds, PCB congeners 103 and 198, were added to all samples prior to extraction to assess the efficiency of the analysis. Sample surrogate recoveries were all within the QC guidelines of $30 \%-150 \%$. Sample results were calculated based on surrogate recoveries.

Five of the 22 congeners and 11 of the 15 pesticides were spiked into one sample. Matrix spike recoveries ranged from $84 \%-124 \%$. One pesticide (4,4'-DDE at 124\%) and one congener (PCB 28 at 121\%) exceeded the control limit range of $50 \%-120 \%$.

One sample was analyzed in triplicate. Precision was measured by calculating the relative standard deviation (RSD) between the replicate results. RSDs for all detectable pesticide values were below the target precision goal of $\leq 30 \%$. RSDs for all detectable congeners, except PCB 28, exceeded the control limit. Two of the three replicates were similar; however, the second replicate was high. No apparent reason for this was observed and it may be due to sample nonhomogeneity.

SRM 1941a, a marine sediment obtained from the National Institute for Science and Technology (NIST), was analyzed with the test samples. $1941 \mathrm{a}$ is certified for 13 of the 22 PCB congeners and 4 of the 15 pesticide compounds analyzed. All four pesticides and all but three PCB congeners were detected within $30 \%$ of the certified mean.

All congener and pesticide results were confirmed using a second dissimilar column. Results for each column were required to be within a factor of two to be considered a confirmed value.

\section{REFERENCES}

NYSDEC (New York Department of Environmental Conservation). 1992. Analytical Method for the Determination of PCB Congeners by Fused Silica Capillary Column Gas Chromatography with Electron Capture Detector. NYSDEC Method 91-11. New York State Department of Environmental Conservation, Albany, New York.

EPA (U.S. Environmental Protection Agency). 1986. Test Methods for Evaluating Solid Waste: Physical/Chemical Methods. SW-846. U.S. Document No. 955-001-00000, U.S.

Environmental Protection Agency, Washington D. C. 


\section{QA/QC SUMMARY}

PROGRAM: $\quad$ New York/Federal.Projects 5

PARAMETER: $\quad$ Polynuclear Aromatic Hydrocarbons (PAH) and 1,4-Dichlorobenzene

LABORATORY: Battelle/Marine Sciences Laboratory, Sequim, Washington

MATRIX: Sediment

QA/QC DATA QUALITY OBJECTIVES

\begin{tabular}{cccccc}
$\begin{array}{c}\text { Reference } \\
\text { Method }\end{array}$ & $\begin{array}{c}\text { MS } \\
\text { Recovery }\end{array}$ & $\begin{array}{c}\text { Surrogate } \\
\text { Recovery }\end{array}$ & $\begin{array}{c}\text { SRM } \\
\text { Accuracy }\end{array}$ & $\begin{array}{c}\text { Relative } \\
\text { Precision }\end{array}$ & $\begin{array}{c}\text { Target } \\
\begin{array}{c}\text { Detection } \\
\text { Limit (dry wt) }\end{array}\end{array}$ \\
\cline { 1 - 4 } GC/MS/SIM & $50-120 \%$ & $30-150 \%$ & $\leq 30 \%$ & $\leq 30 \%$ & $10 \mathrm{ng} / \mathrm{g}$
\end{tabular}

METHOD Sediment samples were extracted with methylene chloride using a roller under ambient conditions, following a procedure based on methods used by the National Oceanic and Atmospheric Administration for its Status and Trends Program (NOAA 1993). Samples were then cleaned using silica/alumina ( $5 \%$ deactivated) chromatography followed by high performance liquid chromatography (HPLC) cleanup.

Extracts were quantified using gas chromatography/mass spectrometry (GC/MS) in the selected ion mode (SIM) following a procedure based on NOAA (1993).

HOLDING TIMES Samples were received on 5/30/95 and were entered into Battelle's log-in system. Samples were stored frozen at approximately $-20^{\circ} \mathrm{C}$ until extraction. Samples were extracted on 6/22/95. All extracts were analyzed by GC/MS/SIM on 7/24-25/95, within the 180-day holding time.

DETECTION LIMITS Target detection limits of $10 \mathrm{ng} / \mathrm{g}$ dry wt were met for all PAH compounds. Method detection limits (MDLs) were determined by multiplying the standard deviation of seven spiked replicates of a background clam sample by the student's $t-v a l u e(t=3.142)$. 


\section{QA/QC SUMMARYIPAHs (continued)}

\section{METHOD BLANKS}

SURROGATES

MATRIX SPIKES

REPLICATES

SRMs

MISCELLANEOUS
One method blank was extracted with the extraction batch.

Naphthalene and benz[a]anthracene were detected in the blank. All blank levels were less than the target MDL of $10 \mathrm{ng} / \mathrm{g}$ dry weight and all sample concentrations were well above five times the blank concentration. Therefore, no data were flagged and data were not blank corrected.

Five isotopically labeled compounds were added prior to extraction to assess the efficiency of the extraction method. These were d8-naphthalene, d10-acenaphthene, d12-chrysene, d14-dibenzo[a,h]anthracene and d4-1,4 dichlorobemzene. All surrogate recoveries were within the quality control limits of $30 \%$ $150 \%$ with the exception of dibenzo[a, h]anthracene in one sample $(161 \%)$. All sample results are surrogate corrected.

One sample was spiked with all PAH compounds. Matrix spike recoveries were within the QC limits of $50 \%-120 \%$, except for a small deviation for two PAH compounds (Recoveries of chrysene and benzo[b]fluoranthene were $123 \%$ and $124 \%$, respectively.) All recoveries were below $130 \%$ and were considered accurate.

One sample was extracted and analyzed in triplicate. Precision was measured by calculating the relative standard deviation (RSD) between the replicate results. RSDs ranged from $1 \%$ to $18 \%$ and were within $\pm 30 \%$, indicating acceptable precision.

SRM 1941a, a marine sediment obtained from the National Institute for Science and Technology (NIST), was analyzed with the test samples. SRM 1941a is certified for 14 of the 16 PAH compounds analyzed. Eleven of the 14 PAHs were detected within $30 \%$ of the certified mean. Three compounds, chrysene, benzo[b]fluoranthene and dibenzo[a,h]anthracene, were recovered above the certified range at recoveries ranging from $32 \%$ to $62 \%$. These three compounds coelute with other compounds that are specific to the SRM and should not affect test sample data.

For several compounds, the ion-ratio was outside of the QC range, due to low levels in the native sediment. When the native levels are low, the error associated with the concentration measurement of the confirmation ion, which is present at a fraction of the parent ion concentration, increases. Because the confirmation ion is quantified solely from the parent ion, this will not affect the quality of the data. 


\section{QA/QC SUMMARYIPAHs (continued)}

\section{REFERENCES}

NOAA (National Oceanic and Atmospheric Administration). 1993. Sampling and Analytical Methods for the National Status and Trends Program, National Benthic Surveillance and Mussel Watch Projects 1984-1992. Volume IV. Comprehensive Descriptions of Trace Organic Analytical Methods. G.G. Lauenstein and A. Y. Cantillo, eds. NOAA Technical Memorandum NOS ORCA 71. National Oceanic and Atmospheric Administration, Coastal Monitoring and Bioeffects Assessment Division, Office of Ocean Resources Conservation and Assessment, Silver Spring, Maryland.

EPA (U.S. Environmental Protection Agency). 1986. Test Methods for Evaluating Solid Waste: Physical/Chemical Methods. SW-846. U.S. Document No. 955-001-00000, U.S. Environmental Protection Agency, Washington D.C. 
Table A.1. Grain Size of Sediment Samples, Bronx River

\begin{tabular}{|c|c|c|c|c|c|c|}
\hline \multirow[b]{2}{*}{ Sediment Treatment } & \multirow[b]{2}{*}{ Replicate } & \multirow[b]{2}{*}{ Batch } & \multicolumn{4}{|c|}{ Total Percent (dry wt) } \\
\hline & & & $\begin{array}{c}\text { Gravel } \\
>2000 \mu \mathrm{m} \\
\end{array}$ & $\begin{array}{c}\text { Sand } \\
62.5- \\
2000 \mu \mathrm{m}\end{array}$ & $\begin{array}{c}\text { Silt } \\
3.9- \\
62.5 \mu \mathrm{m}\end{array}$ & $\begin{array}{c}\text { Clay } \\
<3.9 \mu \mathrm{m} \\
\end{array}$ \\
\hline$B X-1$ & 1 & 1 & 2 & 19 & 43 & 36 \\
\hline $\mathrm{BX}-2$ & 1 & 1 & 0 & 14 & 41 & 45 \\
\hline$B X-3$ & 1 & 1 & 0 & 13 & 45 & 42 \\
\hline$B X-4$ & 1 & 1 & 0 & 6 & 49 & 45 \\
\hline BX-5 & 1 & 1 & 5 & 19 & 43 & 33 \\
\hline$B X-6$ & 1 & 1 & 1 & 11 & 47 & 41 \\
\hline$B X-7$ & 1 & 1 & 3 & 36 & 40 & 21 \\
\hline$B X-8$ & 1 & 1 & 5 & 25 & 40 & 30 \\
\hline$B X-9$ & 1 & 1 & 9 & 27 & 42 & 22 \\
\hline$B X-10$ & 1 & 1 & 0 & 14 & 58 & 28 \\
\hline$B X-11$ & 1 & 1 & 27 & 37 & 25 & 11 \\
\hline $\mathrm{BX}-12$ & 1 & 1 & 0 & 9 & 48 & 43 \\
\hline$B X-13$ & 1 & 1 & 0 & 12 & 43 & 45 \\
\hline$B X-14$ & 1 & 1 & 0 & 14 & 48 & 38 \\
\hline$B X-15$ & 1 & 1 & 30 & 46 & 17 & 7 \\
\hline MDRS $^{(a)}$ & 1 & 1 & 0 & 97 & 1 & 2 \\
\hline Ampelisca Control & 1 & 1 & 0 & 9 & 67 & 24 \\
\hline Mysidopsis/Macoma Control & 1 & 1 & 0 & 23 & 45 & 32 \\
\hline Nereis Control & 1 & 1 & 0 & 72 & 15 & 13 \\
\hline
\end{tabular}

(a) MDRS Mud Dump Reference Site. 
Table A.2. Quality Control Data for Sediment Grain Size Analysis

\begin{tabular}{|c|c|c|c|c|c|c|}
\hline \multirow[b]{2}{*}{$\begin{array}{l}\text { Sediment } \\
\text { Treatment }\end{array}$} & \multirow[b]{2}{*}{ Replicate } & \multirow[b]{2}{*}{ Batch } & \multicolumn{4}{|c|}{ Total Percent (dry wt) } \\
\hline & & & $\begin{array}{c}\text { Gravel } \\
>2000 \mu \mathrm{m}\end{array}$ & $\begin{array}{c}\text { Sand } \\
62.4- \\
2000 \mu \mathrm{m} \\
\end{array}$ & $\begin{array}{c}\text { Silt } \\
3.9- \\
62.4 \mu \mathrm{m} \\
\end{array}$ & $\begin{array}{c}\text { Clay } \\
<3.9 \mu \mathrm{m} \\
\end{array}$ \\
\hline $\mathrm{SH}-5^{(\mathrm{a})}$ & 1 & 1 & 0 & 31 & 41 & 28 \\
\hline $\mathrm{SH}-5$ & 2 & 1 & 0 & 30 & 38 & 32 \\
\hline $\mathrm{SH}-5$ & 3 & 1 & 1 & 31 & 37 & 31 \\
\hline RSD (\%) & & & $N A^{(0)}$ & 2 & 5 & 7 \\
\hline SR $-11^{(a)}$ & 1 & 1 & 0 & 33 & 41 & 26 \\
\hline SR-11 & 2 & 1 & 0 & 31 & 42 & 27 \\
\hline SR-11 & 3 & 1 & 0 & 33 & 40 & 27 \\
\hline RSD (\%) & & & NA & 4 & 2 & 2 \\
\hline$W C-11^{(a)}$ & 1 & 1 & 1 & 12 & 40 & 47 \\
\hline WC-11 & 2 & 1 & 1 & 10 & 43 & 46 \\
\hline WC-11 & 3 & 1 & 1 & 12 & 42 & 45 \\
\hline RSD (\%) & & & NA & 10 & 4 & 2 \\
\hline
\end{tabular}

(a) Sample randomly selected for use as a quality control sample in analytical batch.

(b) NA Not applicable, fraction less than five percent of total. 
Table A.3. Specific Gravity and Bulk Density of Sediment Samples and Quality Control Data, Bronx River

\begin{tabular}{|c|c|c|c|c|c|}
\hline & \multirow[b]{2}{*}{ Replicate } & \multirow[b]{2}{*}{ Batch } & \multicolumn{2}{|c|}{ Bulk Density } & \multirow[b]{2}{*}{$\begin{array}{l}\text { Specific } \\
\text { Gravity }\end{array}$} \\
\hline $\begin{array}{l}\text { Sediment } \\
\text { Treatment }\end{array}$ & & & $\begin{array}{c}\text { Wet } \\
\mathrm{Ibs} / \mathrm{ft}^{3}\end{array}$ & $\begin{array}{c}\text { Dry } \\
\mathrm{Ibs} / \mathrm{ft}^{3}\end{array}$ & \\
\hline BX COMP & 1 & 1 & 85 & 35 & 2.57 \\
\hline \multicolumn{6}{|c|}{ Quality Control Data } \\
\hline \multicolumn{6}{|c|}{ Analytical Replicates } \\
\hline WC COMP ${ }^{(a)}$ & 1 & 1 & 81 & 30 & 2.52 \\
\hline WC COMP & 2 & 1 & 81 & 31 & 2.51 \\
\hline WC COMP & 3 & 1 & 81 & 30 & 2.53 \\
\hline & & & 0 & 2 & 0 \\
\hline
\end{tabular}

(a) Sample randomly selected for use as a quality control sample in analytical batch. 
Table A.4. Total Organic Carbon (TOC) and Percentage of Moisture in Sediment Samples, Bronx River

\begin{tabular}{lccccc}
$\begin{array}{l}\text { Sediment } \\
\text { Treatment }\end{array}$ & Replicate & Batch & $\begin{array}{c}\text { TOC } \\
(\% \text { dry wt.) }\end{array}$ & $\begin{array}{c}\text { Solids } \\
(\%)\end{array}$ & $\begin{array}{c}\text { Moisture } \\
(\%)\end{array}$ \\
\hline BX-1 & 1 & 2 & 5.31 & 49 & 51 \\
BX-2 & 1 & 2 & 5.82 & 32 & 68 \\
BX-3 & 1 & 2 & 5.53 & 32 & 68 \\
BX-4 & 1 & 2 & 4.97 & 47 & 53 \\
BX-5 & 1 & 2 & 8.71 & 36 & 64 \\
BX-6 & 1 & 2 & 6.13 & 39 & 61 \\
BX-7 & 1 & 2 & 6.14 & 41 & 59 \\
BX-8 & 1 & 2 & 6.69 & 41 & 59 \\
BX-9 & 1 & 2 & 5.72 & 45 & 55 \\
BX-10 & 1 & 2 & 7.77 & 28 & 72 \\
BX-11 & 1 & 2 & 4.46 & 55 & 45 \\
BX-12 & 1 & 2 & 5.91 & 30 & 70 \\
BX-13 & 1 & 2 & 5.45 & 33 & 67 \\
BX-13 & 2 & 2 & 5.41 & NA & (a) \\
BX-13 & 3 & 2 & 5.44 & NA & NA \\
BX-14 & 1 & 3 & 6.49 & 31 & 69 \\
BX-15 & 1 & 3 & 0.66 & 80 & 20 \\
& & & & & \\
MDRS ${ }^{\text {(b) }}$ & 1 & 3 & 0.07 & 80 & 20 \\
Ampelisca Control & 1 & 3 & 3.35 & 38 & 62 \\
Macoma/Mysidopsis Control & 1 & 3 & 2.43 & 32 & 68 \\
Nereis Control & 1 & 3 & 5.45 & 49 & 51 \\
Nereis Control & 2 & 3 & 5.27 & NA & NA \\
Nereis Control & 3 & 3 & 5.41 & NA & NA \\
& & & & & \\
(a) NA Not applicable. & & & & & \\
(b) MDRS Mud Dump Reference Site. & & & &
\end{tabular}


Table A.5. Quality Control Data for Total Organic Carbon (TOC) Analysis of Sediment Samples

Sediment

TOC

Treatment

Replicate

Batch

(\% dry wt.)

Standard Reference Material

NIST 1941a

NIST 1941a

NIST 1941a

1

1

1

1

4.88

4.85

4.79

Non-Certified Value

4.80

Range

$\pm 1.2$

Percent Difference

$\begin{array}{ll}1 & 2 \\ 2 & 1 \\ 3 & 0\end{array}$

Analytical Replicates for TOC

SR-9 $9^{(a)}$

SR-9

SR-9

RSD (\%)

$\begin{array}{lll}1 & 1 & 1.46 \\ 2 & 1 & 1.40 \\ 3 & 1 & 1.46\end{array}$

$B X-13^{\text {(a) }}$

$B X-13$

$B X-13$

1
2
3

$2 \quad 5.45$

$2 \quad 5.41$

$2 \quad 5.44$

RSD (\%)

0

Nereis Control

Nereis Control

Nereis Control

$\begin{array}{ccc}1 & 3 & 5.45 \\ 2 & 3 & 5.27 \\ 3 & 3 & 5.41 \\ & & 2\end{array}$

(a) Sample randomly selected for use as a quality control sample in analytical batch. 
Table A.6. Quality Control Data for Percentage Moisture Analysis of Sediment Samples

Sediment

Treatment

Replicate Batch

Solids

Moisture

Analytical Replicates for \% Moisture

$\mathrm{SH}-5^{(\mathrm{a})}$

$\mathrm{SH}-5$

SH-5

1

$2-1$

3

RSD (\%)

138

38

62

38

38

62

62

0

(\%)

SR-11 $1^{\text {(a) }}$

SR-11

SR-11

RSD (\%)

$\begin{array}{ll}1 & 1 \\ 2 & 1 \\ 3 & 1\end{array}$

54

54

54

0

0

WC-11 (a)

WC-11

WC-11

1
2
3

1
1
1

$\begin{array}{cc}30 & 70 \\ 30 & 70 \\ 30 & 70 \\ 0 & 0\end{array}$

(a) Sample randomly selected for use as a quality control sample in analytical batch. 
Table A.7. Metals in Sediment Samples, Bronx River

\begin{tabular}{|c|c|c|c|c|c|c|c|c|c|c|c|}
\hline \multirow[b]{2}{*}{$\begin{array}{l}\text { Sediment } \\
\text { Treatment }\end{array}$} & & \multicolumn{9}{|c|}{ (Concentration $\mathrm{mg} / \mathrm{kg}$ dry $\mathrm{wt}$ ) } \\
\hline & $\begin{array}{l}\text { Analyt } \\
\text { Replicate } \\
\end{array}$ & $\begin{array}{l}\text { ical } \\
\text { Batch }\end{array}$ & $\begin{array}{c}\mathrm{Ag} \\
\text { GFAA }\end{array}$ & $\begin{array}{c}\text { As } \\
\text { ICPMS }\end{array}$ & $\begin{array}{c}\mathrm{Cd} \\
\text { ICPMS }\end{array}$ & $\begin{array}{c}\mathrm{Cr} \\
\text { ICP/MS } \\
\end{array}$ & $\begin{array}{c}\mathrm{Cu} \\
\text { ICP/MS }\end{array}$ & $\begin{array}{c}\mathrm{Hg} \\
\text { CVAA } \\
\end{array}$ & $\begin{array}{c}\mathrm{Ni} \\
\text { ICPMS } \\
\end{array}$ & $\begin{array}{c}\mathrm{Pb} \\
\text { ICPMS }\end{array}$ & $\begin{array}{c}\mathrm{Zn} \\
\text { ICPMS }\end{array}$ \\
\hline Target & ction Limit: & & 0.1 & 0.1 & 0.01 & 0.02 & 0.1 & 0.02 & 0.1 & 0.1 & 0.1 \\
\hline Method & ction Limit: & & 0.007 & 0.426 & 0.025 & 0.235 & 0.485 & 0.0017 & 0.217 & 0.238 & 1.25 \\
\hline$B \times$ COMP & 1 & 1 & 7.04 & 10.9 & 3.96 & 115 & 191 & 1.45 & 38.6 & 602 & 422 \\
\hline BX COMP & 2 & 1 & 7.38 & 10.6 & 3.89 & 112 & 189 & 1.50 & 38.8 & 373 & 442 \\
\hline$B X$ COMP & 3 & 1 & 6.27 & 10.7 & 3.56 & 108 & 179 & 1.43 & 37.9 & 629 & 361 \\
\hline
\end{tabular}


Table A.8. Quality Control Data for Metals Analysis of Sediment Samples

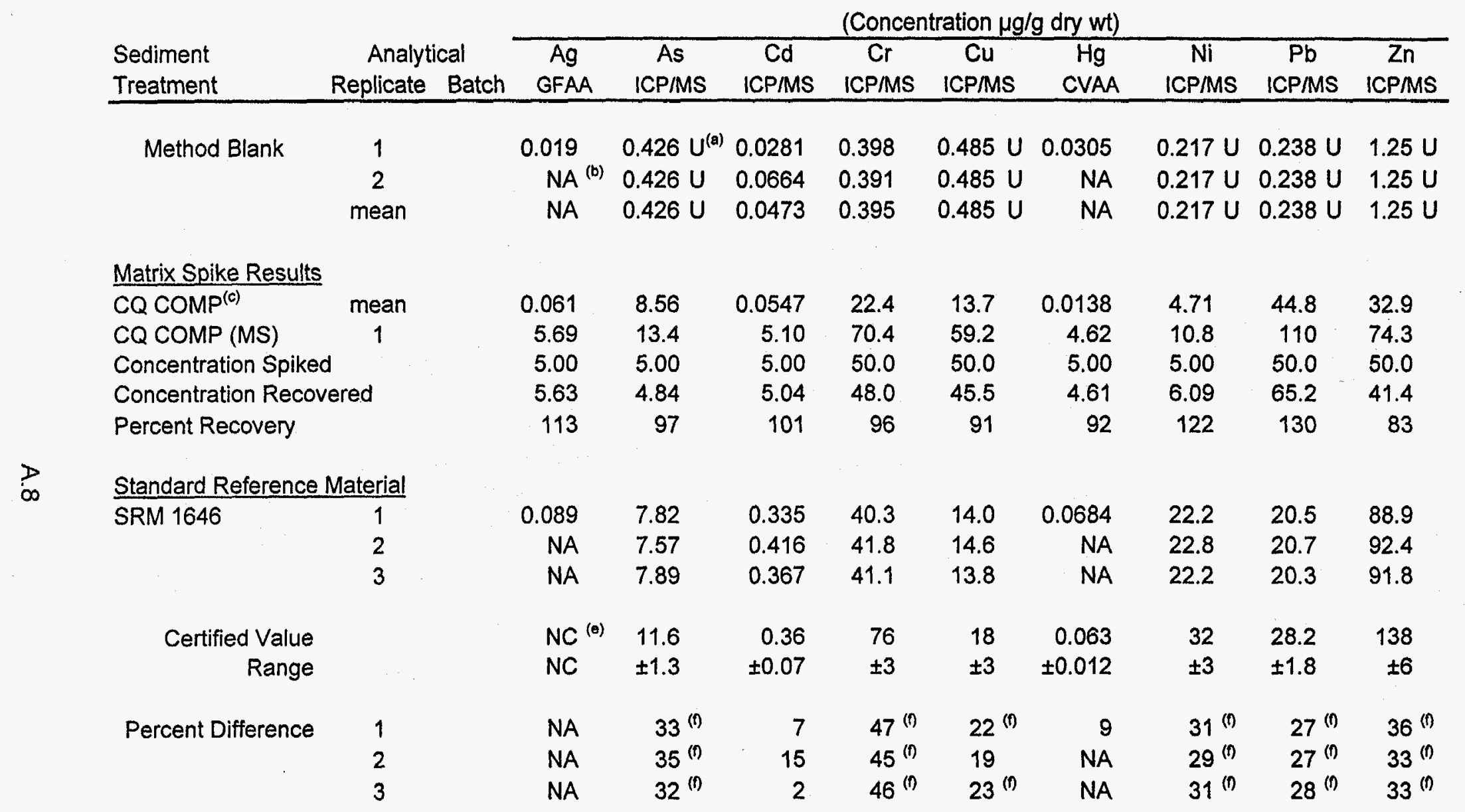


Table A.8 (contd)

\begin{tabular}{|c|c|c|c|c|c|c|c|c|c|c|}
\hline \multirow[b]{2}{*}{$\begin{array}{l}\text { Sediment } \\
\text { Treatment }\end{array}$} & \multirow[b]{2}{*}{$\begin{array}{c}\text { Analytical } \\
\text { Replicate Batch } \\
\end{array}$} & \multicolumn{9}{|c|}{ (Concentration $\mu g / g$ dry wt) } \\
\hline & & $\begin{array}{c}\mathrm{Ag} \\
\text { GFAA }\end{array}$ & $\begin{array}{c}\text { As } \\
\text { ICP/MS }\end{array}$ & $\begin{array}{c}\text { Cd } \\
\text { ICP/MS }\end{array}$ & $\begin{array}{c}\mathrm{Cr} \\
\text { ICP/MS }\end{array}$ & $\begin{array}{c}\mathrm{Cu} \\
\text { ICP/MS }\end{array}$ & $\begin{array}{l}\mathrm{Hg} \\
\text { CVAA }\end{array}$ & $\begin{array}{c}\mathrm{Ni} \\
\text { ICP/MS }\end{array}$ & $\begin{array}{c}\mathrm{Pb} \\
\text { ICP/MS }\end{array}$ & $\begin{array}{c}\mathrm{Zn} \\
\text { ICP/MS }\end{array}$ \\
\hline \multicolumn{11}{|c|}{ Analytical Replicates } \\
\hline$B X \mathrm{COMP}^{(\mathrm{c})}$ & 1 & 7.04 & 10.9 & 3.96 & 115 & 191 & 1.48 & 38.6 & 602 & 422 \\
\hline BX COMP & 2 & 7.38 & 10.6 & 3.89 & 112 & 189 & 1.54 & 38.8 & 373 & 442 \\
\hline BX COMP & 3 & 6.27 & 10.7 & 3.56 & 108 & 179 & 1.46 & 37.9 & 629 & 361 \\
\hline \multicolumn{2}{|c|}{ RSD (\%) } & 8 & 1 & 6 & 3 & 3 & 3 & 1 & $26^{(g)}$ & 10 \\
\hline
\end{tabular}

(a) U Undetected at or above given concentration.

(b) NA Not applicable.

(c) Sample randomly selected for use as a quality control sample in analytical batch.

(d) Outside quality control criteria $(75-125 \%)$ for spike recovery.

(e) NC Not certified.

$+\quad(f)$ Outside SRM quality control criteria $(\leq 20 \%)$.

(g) Outside quality control criteria $(\leq 20 \%)$ replicate analysis. 
Table A.9. Pesticides and Polychlorinated Biphenyls (PCBs) in Sediment Samples, Bronx River

\begin{tabular}{|c|c|}
\hline & Concentration $(\mu \mathrm{g} / \mathrm{kg}$ dry wt) \\
\hline $\begin{array}{l}\text { Sediment Treatment } \\
\text { Analytical Replicate }\end{array}$ & $\begin{array}{c}\mathrm{BX} \text { COMP } \\
1 \\
\end{array}$ \\
\hline $2,4^{\prime}-D D D^{(a)}$ & 24.1 \\
\hline 2,4'-DDE & $1.05 U^{(b)}$ \\
\hline 2,4'-DDT & $0.37 \mathrm{U}$ \\
\hline 4,4'-DDD & 51.7 \\
\hline 4,4'-DDE & 47.7 \\
\hline 4,4'-DDT & 33.7 \\
\hline$\alpha$-Chlordane & 30.6 \\
\hline Aldrin & 14.6 \\
\hline Dieldrin & $0.32 U$ \\
\hline Endosulfan 1 & $0.55 U$ \\
\hline Endosulfan II & $0.55 \mathrm{U}$ \\
\hline Endosulfan Sulfate & 4.45 \\
\hline Heptachlor & $0.10 \mathrm{U}$ \\
\hline Heptachlor Epoxide & $0.48 \mathrm{U}$ \\
\hline Trans Nonachlor & 16.3 \\
\hline PCB 8 & $0.87 \cup$ \\
\hline PCB 18 & 151 \\
\hline PCB 28 & $0.27 U$ \\
\hline PCB 44 & 44.6 \\
\hline PCB 49 & 31.1 \\
\hline РCB 52 & 57.4 \\
\hline PCB 66 & 65.5 \\
\hline PCB 87 & 16.6 \\
\hline PCB 101 & 46.0 \\
\hline PCB 105 & 24.1 \\
\hline PCB 118 & 48.8 \\
\hline PCB 128 & 9.57 \\
\hline PCB 138 & 86.7 \\
\hline PCB 153 & 77.6 \\
\hline PCB 170 & 26.1 \\
\hline PCB 180 & 57.1 \\
\hline PCB 183 & 24.3 \\
\hline PCB 184 & $0.45 U$ \\
\hline PCB 187 & 44.6 \\
\hline PCB 195 & 6.39 \\
\hline PCB 206 & 10.5 \\
\hline PCB 209 & $0.48 \mathrm{U}$ \\
\hline \multicolumn{2}{|c|}{ Surrogate Recoveries (\%) } \\
\hline PCB 103 (SIS) & 58 \\
\hline PCB 198 (SIS) & 64 \\
\hline
\end{tabular}

(a) Target detection limits are $1.0 \mu \mathrm{g} / \mathrm{kg}$ for all analytes.

(b) $\cup$ Undetected at or above given concentration. 
Table A.10. Quality Control Data for Pesticides and Polychlorinated Byphenyl (PCB) Analysis of Sediment Samples

Matrix Spike Results

\begin{tabular}{|c|c|c|c|c|c|c|}
\hline \multirow{5}{*}{$\begin{array}{l}\text { Sediment Treatment } \\
\text { Analytical Replicate } \\
\text { Batch }\end{array}$} & \multirow{5}{*}{$\begin{array}{c}\overline{\text { Method Blank }} \\
1 \\
1 \\
\end{array}$} & \multirow{2}{*}{\multicolumn{4}{|c|}{ Concentration $(\mu \mathrm{g} / \mathrm{kg}$ dry $w t)$}} & \multirow{5}{*}{$\begin{array}{l}\text { Percent } \\
\text { Recovery }\end{array}$} \\
\hline & & & & & & \\
\hline & & \multirow{3}{*}{$\begin{array}{c}\text { CQ } \text { COMP }^{(a)} \\
1 \\
1\end{array}$} & \multirow{3}{*}{$\begin{array}{c}\text { CQ COMP (MS) } \\
1 \\
1 \\
\end{array}$} & \multicolumn{2}{|c|}{ Concentration } & \\
\hline & & & & \multirow[t]{2}{*}{ Spiked } & \multirow{2}{*}{ Recovered } & \\
\hline & & & & & & \\
\hline $2,4^{\prime}-\mathrm{DDD}$ & $0.26 \mathrm{U}$ & $0.14 \mathrm{U}^{(b)}$ & 0.61 & $N S^{(c)}$ & $N A^{(d)}$ & NA \\
\hline 2,4'-DDE & $0.85 \mathrm{U}$ & $0.48 \mathrm{U}$ & $0.50 \mathrm{U}$ & NS & NA & NA \\
\hline 2,4'-DDT & $0.30 \mathrm{U}$ & $0.17 \mathrm{U}$ & $0.17 \mathrm{U}$ & NS & NA & NA \\
\hline 4,4'-DDD & $0.33 \mathrm{U}$ & $0.19 \mathrm{U}$ & 3.22 & 2.90 & 3.22 & 111 \\
\hline 4,4'-DDE & $0.18 U$ & $0.10 \mathrm{U}$ & 3.59 & 2.90 & 3.59 & $124^{(e)}$ \\
\hline 4,4'-DDT & $0.94 U$ & $0.53 \mathrm{U}$ & 3.06 & 2.90 & 3.06 & 106 \\
\hline$\alpha$-Chlordane & $0.64 \mathrm{U}$ & $0.36 \mathrm{U}$ & 2.99 & 2.90 & 2.99 & 103 \\
\hline Aldrin & $0.27 U$ & $0.15 \mathrm{U}$ & 2.57 & 2.90 & 2.57 & 89 \\
\hline Dieldrin & $0.26 \mathrm{U}$ & $0.15 U$ & 2.58 & 2.90 & 2.58 & 89 \\
\hline Endosulfan I & $0.45 U$ & $0.25 \mathrm{U}$ & 2.45 & 2.90 & 2.45 & 84 \\
\hline Endosulfan II & $0.45 \mathrm{U}$ & $0.25 \mathrm{U}$ & 2.46 & 2.90 & 2.46 & 85 \\
\hline Endosulfan Sulfate & $0.45 \mathrm{U}$ & $0.25 \mathrm{U}$ & 2.59 & 2.90 & 2.59 & 89 \\
\hline Heptachlor & $0.08 \mathrm{U}$ & $0.05 \mathrm{U}$ & 2.90 & 2.90 & 2.90 & 100 \\
\hline Heptachlor Epoxide & $0.39 \mathrm{U}$ & $0.22 \mathrm{U}$ & 2.55 & 2.90 & 2.55 & 88 \\
\hline Trans Nonachlor & $0.29 \mathrm{U}$ & $0.16 \mathrm{U}$ & $0.17 \mathrm{U}$ & NS & NA & NA \\
\hline PCB 8 & $0.70 \mathrm{U}$ & $0.39 \mathrm{U}$ & $0.41 \mathrm{U}$ & NS & NA & NA \\
\hline PCB 18 & $0.20 \mathrm{U}$ & $0.11 \mathrm{U}$ & $0.12 \mathrm{U}$ & NS & NA & NA \\
\hline PCB 28 & $0.22 \mathrm{U}$ & $0.12 \mathrm{U}$ & 5.09 & 4.21 & 5.09 & $121^{(e)}$ \\
\hline PCB 44 & $0.14 U$ & $0.08 \mathrm{U}$ & $0.08 \mathrm{U}$ & NS & NA & NA \\
\hline PCB 49 & $0.37 \mathrm{U}$ & $0.21 \mathrm{U}$ & $0.21 \mathrm{U}$ & NS & NA & NA \\
\hline PCB 52 & $0.65 U$ & $0.36 \mathrm{U}$ & 9.38 & 8.78 & 9.38 & 107 \\
\hline PCB 66 & $0.30 \mathrm{U}$ & $0.17 \mathrm{U}$ & $0.21 \mathrm{U}$ & NS & NA & NA \\
\hline РСB 87 & $0.50 \mathrm{U}$ & $0.28 \mathrm{U}$ & $0.29 \mathrm{U}$ & NS & NA & NA \\
\hline PCB 101 & $0.27 \mathrm{U}$ & $0.15 \mathrm{U}$ & 6.22 & 5.96 & 6.22 & 104 \\
\hline PCB 105 & $0.33 \mathrm{U}$ & $0.19 \mathrm{U}$ & $0.19 \mathrm{U}$ & NS & NA & NA \\
\hline PCB 118 & $0.38 \mathrm{U}$ & $0.21 \mathrm{U}$ & $0.22 \mathrm{U}$ & NS & NA & NA \\
\hline PCB 128 & $0.21 \mathrm{U}$ & $0.12 \mathrm{U}$ & $0.12 \mathrm{U}$ & NS & NA & NA \\
\hline PCB 138 & $0.53 \mathrm{U}$ & $0.30 \mathrm{U}$ & 2.75 & 2.69 & 2.75 & 102 \\
\hline РСB 153 & $0.88 U$ & $0.49 \mathrm{U}$ & 3.70 & 3.48 & 3.70 & 106 \\
\hline PCB 170 & $0.35 \mathrm{U}$ & $0.20 \mathrm{U}$ & $0.20 \mathrm{U}$ & NS & NA & NA \\
\hline РCB 180 & $0.75 U$ & $0.42 \mathrm{U}$ & $0.44 U$ & NS & NA & NA \\
\hline PCB 183 & $0.37 \mathrm{U}$ & $0.21 \mathrm{U}$ & $0.21 \mathrm{U}$ & NS & NA & NA \\
\hline PCB 184 & $0.37 \mathrm{U}$ & $0.21 U$ & $0.21 \mathrm{U}$ & NS & NA & NA \\
\hline PCB 187 & $0.41 \mathrm{U}$ & $0.23 \mathrm{U}$ & $0.24 \mathrm{U}$ & NS & NA & NA \\
\hline PCB 195 & $0.25 \mathrm{U}$ & $0.14 \mathrm{U}$ & $0.15 \mathrm{U}$ & NS & NA & NA \\
\hline РCB 206 & $0.43 U$ & $0.24 \mathrm{U}$ & 0.58 & NS & NA & NA \\
\hline PCB 209 & $0.39 \mathrm{U}$ & $0.22 \mathrm{U}$ & 2.67 & NS & NA & NA \\
\hline \multicolumn{7}{|c|}{ Surrogate Recoveries (\%) } \\
\hline PCB 103 (SIS) & 94 & 47 & 89 & $\mathbf{N}$ & NA & NA \\
\hline PCB 198 (SIS) & 87 & 42 & 100 & $\mathbf{N}$ & NA & NA \\
\hline
\end{tabular}


Table A.10. (contd)

Standard Reference Materia Concentration ( $\mu \mathrm{g} / \mathrm{kg}$ dry $w t)$

Sediment Treatment Analytical Replicate

Batch

2,4'-DDD
2,4'-DDE
2,4'-DDT

4,4'-DDD

4,4'-DDE

4,4'-DDT

$\alpha$-Chlordane

Aldrin

Dieldrin

Endosulfan I

Endosulfan II

Endosulfan Sulfate

Heptachlor

Heptachlor Epoxide

Trans Nonachlor

PCB 8

PCB 18

PCB 28

PCB 44

PCB 49

PCB 52

PCB 66

PCB 87

PCB 101

PCB 105

PCB 118

PCB 128

PCB 138

PCB 153

PCB 170

PCB 180

PCB 183

PCB 184

PCB 187

PCB 195

PCB 206

PCB 209

Surrogate Recoveries (\%)

PCB 103 (SIS)

PCB 198 (SIS)

SRM

SR

$\begin{array}{ccc}\text { SRM } & \text { Certified } & \text { Percent } \\ 1941 a & \text { Value } & \text { Difference }\end{array}$

1

$\begin{array}{ccr}\text { NA } & \text { NA } & \text { NA } \\ 0.57 \text { U } & 0.73 & \text { NA } \\ \text { NA } & \text { NA } & \text { NA } \\ 5.41 & 5.06 & 7 \\ 8.38 & 6.59 & 27 \\ 7.75^{\text {(f) }} & 1.25^{(g)} & 520\end{array}$

$\begin{array}{llr}7.94 & 2.33 & 26\end{array}$

NA NA NA

$0.18 \mathrm{U}$

NA

NA

NA

NA

NA

1.26

$0.47 \mathrm{U}$

$8.60^{(7)}$

$0.15 \mathrm{U}$

7.11

5.91

9.46

8.74

7.59

12.4

4.54

9.23

1.40

11.4

13.6

3.38

6.89

2.42

NA

$0.28 \mathrm{U}$

NA

3.13

10.5

$\begin{array}{lll}84 & \text { NA } & \text { NA } \\ 81 & \text { NA } & \text { NA }\end{array}$

Analytical Replicates

$\frac{\text { Concentration }(\mu g / k g \text { dry wt) }}{\text { SR COMP }{ }^{(a)} \text { SR COMP SR COMP RSD }}$

- 1

$\begin{array}{llll}0.66 & 0.17 U & 0.65 & \text { NA } \\ 0.57 U & 0.57 U & 0.56 U & \text { NA } \\ 0.20 U & 0.20 U & 0.19 U & \text { NA }\end{array}$

$\begin{array}{llll}0.22 U & 0.22 U & 0.22 U & N A\end{array}$

$\begin{array}{llll}2.20 & 1.38 & 2.27 & 25\end{array}$

$\begin{array}{llll}2.38 & 3.14 & 2.14 & 20\end{array}$

$\begin{array}{llll}0.56 & 0.43 U & 0.69 & \text { NA }\end{array}$

$\begin{array}{llll}0.18 U & 0.82 & 0.17 U & \text { NA }\end{array}$

$\begin{array}{llll}0.18 U & 0.18 U & 0.17 U & N A\end{array}$

$\begin{array}{lllll}0.30 U & 0.30 U & 0.29 U & N A\end{array}$

$\begin{array}{llll}0.30 U & 0.30 U & 0.29 U & N A\end{array}$

$\begin{array}{llll}0.30 \mathrm{U} & 0.30 \mathrm{U} & 0.29 \mathrm{U} & \mathrm{NA}\end{array}$

$\begin{array}{llll}0.18 & 0.06 U & 0.05 U & N A\end{array}$

$\begin{array}{llll}0.26 \mathrm{U} & 0.26 \mathrm{U} & 0.25 \mathrm{U} & \mathrm{NA}\end{array}$

$\begin{array}{llll}0.20 U & 0.20 U & 0.19 \mathrm{U} & \mathrm{NA}\end{array}$

$\begin{array}{llll}0.47 U & 0.47 U & 0.46 U & \text { NA }\end{array}$

$\begin{array}{llll}0.14 U & 0.14 U & 0.13 U & N A\end{array}$

$\begin{array}{llll}3.07 & 2.89 & 2.68 & 7\end{array}$

$\begin{array}{llll}0.09 \mathrm{U} & 0.09 \mathrm{U} & 0.09 \mathrm{U} & \mathrm{NA}\end{array}$

$\begin{array}{llll}0.27 & 0.83 & 0.24 U & N A\end{array}$

$\begin{array}{llll}0.43 U & 3.92 & 0.42 \mathrm{U} & \mathrm{NA}\end{array}$

$2.44 \quad 0.20 \mathrm{U} \quad 0.20 \mathrm{U} \quad \mathrm{NA}$

$\begin{array}{llll}0.34 U & 1.79 & 0.33 \mathrm{U} & \text { NA }\end{array}$

$\begin{array}{llll}1.25 & 6.76 & 1.37 & 101^{(i)}\end{array}$

$\begin{array}{llll}0.98 & 2.28 & 0.22 \cup & \text { NA }\end{array}$

$\begin{array}{llll}2.04 & 6.31 & 1.96 & 72\end{array}$

$\begin{array}{llll}0.33 & 1.10 & 0.14 \mathrm{U} & \text { NA }\end{array}$

$\begin{array}{llll}2.36 & 7.77 & 2.44 & 74^{(0)}\end{array}$

$\begin{array}{llll}1.80 & 4.70 & 1.97 & 58\end{array}$

$\begin{array}{llll}0.26 U & 0.77 & 0.30 & \text { NA }\end{array}$

$\begin{array}{llll}0.67 & 1.54 & 0.67 & 52^{(i)}\end{array}$

$\begin{array}{llll}0.56 & 0.99 & 0.47 & 41^{(0)}\end{array}$

$\begin{array}{llll}0.25 U & 0.25 U & 0.24 U & \text { NA }\end{array}$

$\begin{array}{llll}0.28 U & 0.28 U & 0.27 U & \text { NA }\end{array}$

$0.17 \mathrm{U} \quad 0.17 \mathrm{U} \quad 0.16 \mathrm{U} \quad \mathrm{NA}$

$\begin{array}{llll}0.29 U & 0.42 & 0.28 U & N A\end{array}$

$\begin{array}{llll}0.26 U & 0.26 U & 0.72 & N A\end{array}$

(a) Sample randomly selected for use as a quality control sample in analytical batch.

(b) U Undetected at or above given concentration.

(c) NS Not spiked.

(d) NA Not applicable.

(e) Outside quality control criteria (50-120\%) for spike recovery.

(f) Elevated due to interference.

(g) Non-certified value.

(h) Outside SRM quality control criteria $(\leq 30 \%)$.

(i) Outside quality control criteria $(\leq 30 \%)$ for replicate analysis. 
Table A.11. Polynuclear Aromatic Hydrocarbons (PAHs) in Sediment Samples, Bronx River

\begin{tabular}{|c|c|c|c|}
\hline \multirow[b]{2}{*}{ Sediment Treatment } & \multicolumn{3}{|c|}{ Concentration $(\mu \mathrm{g} / \mathrm{kg}$ dry $w t)$} \\
\hline & BX COMP & BX COMP & $\mathrm{BX}$ COMP \\
\hline Analytical Replicate & 1 & 2 & 3 \\
\hline Batch & 1 & 1 & 1 \\
\hline 1,4-Dichlorobenzene ${ }^{(a)}$ & 248 & 246 & 254 \\
\hline Naphthalene & 987 & 1020 & 966 \\
\hline Acenaphthylene & 527 & 609 & 507 \\
\hline Acenaphthene & 585 & 623 & 575 \\
\hline Fluorene & 664 & 670 & 639 \\
\hline Phenanthrene & 3190 & 3160 & 3020 \\
\hline Anthracene & 1500 & 1560 & 1420 \\
\hline Fluoranthene & 6680 & 6510 & 6460 \\
\hline Pyrene & 7360 & 7330 & 7230 \\
\hline Benzo[a]anthracene & 3850 & 3950 & 3780 \\
\hline Chrysene & 4690 & 4640 & 4570 \\
\hline Benzo[b]fluoranthene & 6040 & 6090 & 5910 \\
\hline Benzo[k]fluoranthene & $-{ }^{(b)}$ & $-{ }^{(b)}$ & -. (b) \\
\hline Benzo[a]pyrene & 4020 & 4080 & 3870 \\
\hline Indeno[123-cd]pyrene & 2300 & 2540 & 3240 \\
\hline Dibenzo[a,h]anthracene & 597 & 669 & 788 \\
\hline Benzo[g,h,i]perylene & 2400 & 2620 & 3050 \\
\hline \multicolumn{4}{|l|}{ Surrogate Recoveries (\%) } \\
\hline d4 1,4-Dichlorobenzene & 50 & 52 & 49 \\
\hline d8 Naphthalene & 55 & 55 & 53 \\
\hline d10 Acenaphthene & 61 & 59 & 57 \\
\hline d12 Chrysene & 61 & 58 & 57 \\
\hline d14 Dibenzo[a,h]anthracene & $161^{\text {(c) }}$ & 69 & 90 \\
\hline \multicolumn{4}{|c|}{$\begin{array}{l}\text { (a) Target detection limit is } 10 \mu \mathrm{g} / \mathrm{kg} \text { for all analytes } \\
\text { (except for 1,4-Dichlorobenzene which is } 1 \mu \mathrm{g} / \mathrm{kg} \text { ). } \\
\text { (b) Benzo(b)fluoranthene is the sum of benzo(b)fluoranthene and benzo(k)fluoranthene. } \\
\text { Benzo(k)fluoranthene is present but could not be quantified due to co-eluting peak. } \\
\text { (c) Outside quality control criteria }(30-150 \%) \text { for surrogate recovery. }\end{array}$} \\
\hline
\end{tabular}


Table A.12. Quality Control Data for Polynuclear Aromatic Hydrocarbon (PAH) Analysis of Sediment Samples

Matrix Spike Results

Concentration $(\mu \mathrm{g} / \mathrm{kg}$ dry $w t)$

\begin{tabular}{|c|c|c|c|c|c|c|}
\hline \multirow{4}{*}{$\begin{array}{r}\text { Sediment Treatment } \\
\text { Analytical Replicate } \\
\text { Batch }\end{array}$} & \multirow{4}{*}{$\begin{array}{c}\text { Blank } \\
1 \\
1\end{array}$} & \multirow{4}{*}{\multicolumn{2}{|c|}{$\begin{array}{cc}\text { CQ COMP }^{(\text {a) }} & \text { CQ COMP (MS) } \\
1 & 1 \\
1 & 1 \\
\end{array}$}} & \multirow{2}{*}{\multicolumn{2}{|c|}{ Concentration }} & \multirow{4}{*}{ Percent } \\
\hline & & & & & & \\
\hline & & & & \multirow{2}{*}{ Spiked } & \multirow{2}{*}{ Recovered } & \\
\hline & & & & & & \\
\hline 1,4-Dichlorobenzene & $2.83 U$ & $1.53 U^{(b)}$ & $1.38^{(\mathrm{c})}$ & $N S^{(d)}$ & $N A^{(e)}$ & NA \\
\hline Naphthalene & 8.97 & 5.89 & 30.3 & 23.0 & 24.4 & 106 \\
\hline Acenaphthylene & $3.00 \mathrm{U}$ & $1.62 \mathrm{U}$ & 26.5 & 23.0 & 26.5 & 115 \\
\hline Acenaphthene & $2.69 \mathrm{U}$ & 1.69 & 25.6 & 23.0 & 23.9 & 104 \\
\hline Fluorene & $5.36 \mathrm{U}$ & $2.89 \mathrm{U}$ & 27.2 & 23.0 & 27.2 & 118 \\
\hline Phenanthrene & $6.33 \mathrm{U}$ & 7.68 & 33.3 & 23.0 & 25.6 & 111 \\
\hline Anthracene & $7.69 \mathrm{U}$ & $4.15 \mathrm{U}$ & 24.3 & 23.0 & 24.3 & 106 \\
\hline Fluoranthene & $2.91 \mathrm{U}$ & 14.7 & 38.4 & 23.0 & 23.8 & NA \\
\hline Pyrene & $2.16 \mathrm{U}$ & 14.8 & 40.3 & 23.0 & 25.5 & NA \\
\hline Benzo[a]anthracene & $2.17^{\text {(c) }}$ & 6.27 & 33.1 & 23.0 & 26.8 & 116 \\
\hline Chrysene & $1.17 \mathrm{U}$ & 7.51 & 35.7 & 23.0 & 28.2 & $123^{(f)}$ \\
\hline Benzo[b]fluoranthene & $2.22 \mathrm{U}$ & 11.1 & 39.6 & 23.0 & 28.6 & $124^{(f)}$ \\
\hline Benzo[k]fluoranthene & $3.76 \mathrm{U}$ & 4.48 & 30.6 & 23.0 & 26.1 & 113 \\
\hline Benzo[a]pyrene & $2.93 \mathrm{U}$ & 6.69 & 32.2 & 23.0 & 25.5 & 111 \\
\hline Indeno[123-cd]pyrene & $1.34 U$ & 5.55 & 25.6 & 23.0 & 20.0 & 87 \\
\hline Dibenzo[a,h]anthracene & $1.70 \mathrm{U}$ & $2.17^{(\mathrm{c})}$ & 19.9 & 23.0 & 17.8 & 77 \\
\hline Benzo[g,h,i]perylene & $1.23 \mathrm{U}$ & 5.64 & 25.4 & 23.0 & 19.7 & 86 \\
\hline \multicolumn{7}{|l|}{ Surrogate Recoveries (\%) } \\
\hline d4 1,4-Dichlorobenzene & 70 & 61 & 67 & NA & NA & NA \\
\hline d8 Naphthalene & 71 & 61 & 67 & NA & NA & NA \\
\hline d10 Acenaphthene & 68 & 62 & 67 & NA & NA & NA \\
\hline d12 Chrysene & 76 & 71 & 77 & NA & NA & NA \\
\hline d14 Dibenzo[a,h]anthracene & 60 & 41 & 47 & NA & NA & NA \\
\hline
\end{tabular}


Table A.12. (contd)

Standard Reference Material

Sediment Treatment Analytical Replicate Batch
1,4-Dichlorobenzene

Naphthalene

Acenaphthylene

Acenaphthene

Fluorene

Phenanthrene

Anthracene

Fluoranthene

Pyrene

Benzo[a]anthracene

Chrysene

Benzo[b]fluoranthene

Benzo[k]fluoranthene

Benzo[a]pyrene

Indeno[123-cd]pyrene

Dibenzo[a,h]anthracene

Benzo[g,h,i]perylene

Surrogate Recoveries (\%)

d4 1,4-Dichlorobenzene

d8 Naphthalene

d10 Acenaphthene

d12 Chrysene

d14 Dibenzo[a, h]anthracene
108

1100

63.5

45.2

90.9

503

190

917

756

438

615

1130

385

547

400

97.9

383

46

52

59

66

37 centration ( $\mu \mathrm{g} / \mathrm{kg}$ dry wt)

1

Range Difference

-

$\begin{array}{ccc}\text { NA } & \text { NA } & \text { NA } \\ 1010 & 140 & 9 \\ 37^{(9)} & 14 & 72 \\ 41^{(9)} & 10 & 10 \\ 97.3 & 8.6 & 7 \\ 489 & 23 & 3 \\ 184 & 14 & 3 \\ 981 & 78 & 7 \\ 811 & 24 & 7 \\ 427 & 25 & 3 \\ 380 & 24 & 62^{(h)} \\ 740 & 110 & 53^{(h)} \\ 361 & 18 & 7 \\ 628 & 52 & 13 \\ 501 & 72 & 20 \\ 73.9 & 9.7 & 32^{(h)} \\ 525 & 67 & 27\end{array}$


Table A.12. (contd)

Analytical Replicates

\begin{tabular}{|c|c|c|c|c|}
\hline \multirow{4}{*}{ Sediment Treatment } & \multirow{2}{*}{\multicolumn{3}{|c|}{ Concentration ( $\mu \mathrm{g} / \mathrm{kg}$ dry $w t)$}} & \multirow{5}{*}{$\begin{array}{c}\text { RSD } \\
\text { (\%) }\end{array}$} \\
\hline & & & & \\
\hline & $\mathrm{BX} \mathrm{COMP}^{(\mathrm{a})}$ & $\mathrm{BX}$ COMP & BX COMP & \\
\hline & 1 & 2 & 3 & \\
\hline Batch & 1 & 1 & 1 & \\
\hline 1,4-Dichlorobenzene & 248 & 246 & 254 & 2 \\
\hline Naphthalene & 987 & 1020 & 966 & 3 \\
\hline Acenaphthylene & 527 & 609 & 507 & 10 \\
\hline Acenaphthene & 585 & 623 & 575 & 4 \\
\hline Fluorene & 664 & 670 & 639 & 3 \\
\hline Phenanthrene & 3190 & 3160 & 3020 & 3 \\
\hline Anthracene & 1500 & 1560 & 1420 & 5 \\
\hline Fluoranthene & 6680 & 6510 & 6460 & 2 \\
\hline Pyrene & 7360 & 7330 & 7230 & 1 \\
\hline Benzo[a]anthracene & 3850 & 3950 & 3780 & 2 \\
\hline Chrysene & 4690 & 4640 & 4570 & 1 \\
\hline Benzo[b]fluoranthene & $6040^{\text {(i) }}$ & $6090^{(1)}$ & $5910^{(i)}$ & 2 \\
\hline Benzo[k]fluoranthene & $-{ }^{(i)}$ & $-(i)$ & $-(i)$ & NA \\
\hline Benzo[a]pyrene & 4020 & 4080 & 3870 & 3 \\
\hline Indeno[123-cd]pyrene & 2300 & 2540 & 3240 & 18 \\
\hline Dibenzo[a,h]anthracene & 597 & 669 & 788 & 14 \\
\hline Benzo[g,h,i]perylene & 2400 & 2620 & 3050 & 12 \\
\hline \multicolumn{5}{|l|}{ Surrogate Recoveries (\%) } \\
\hline d4 1,4-Dichlorobenzene & 50 & 52 & 49 & NA \\
\hline d8 Naphthalene & 55 & 55 & 53 & NA \\
\hline d10 Acenaphthene & 61 & 59 & 57 & NA \\
\hline d12 Chrysene & 61 & 58 & 57 & NA \\
\hline d14 Dibenzo[a,h]anthracene & $161^{(j)}$ & 69 & 90 & NA \\
\hline
\end{tabular}

(a) Sample randomly selected for use as a quality control sample in analytical batch.

(b) U Undetected at or above given concentration.

(c) Ion ratio out or confirmation ion not detected.

(d) NS Not spiked.

(e) NA Not applicable.

(f) Outside quality control criteria (50-120\%) for spike recovery.

(g) Non-certified value.

(h) Outside SRM quality control criteria $(\leq 30 \%)$.

(i) Benzo(b)fluoranthene is the sum of benzo(b)fluoranthene and benzo(k)fluoranthene. Benzo(k)fluoranthene is present but could not be quantified due to co-eluting peak.

(j) Outside quality control criteria (30-150\%) for surrogate recovery. 


\section{Appendix B}

Site Water and Elutriate Chemical Analyses and Quality Control/Quality Assurance Data, Bronx River Project 



\section{QAIQC SUMMARY}

PROGRAM: $\quad$ New York 5

PARAMETER: Metals

LABORATORY: Battelle/Marine Sciences Laboratory, Sequim, Washington

MATRIX: $\quad$ Site Water/Elutriate

QA/QC DATA QUALITY OBJECTIVES

$\begin{array}{lccccc}\text { Cadmium } & \begin{array}{c}\text { Reference } \\ \text { Method }\end{array} & \begin{array}{c}\text { Range of } \\ \text { Recovery }\end{array} & \begin{array}{c}\text { SRM } \\ \text { Accuracy }\end{array} & \begin{array}{c}\text { Relative } \\ \text { Precision }\end{array} & \begin{array}{c}\text { Target } \\ \text { Detection } \\ \text { Limit }\end{array} \\ \text { Chromium } & \text { ICP/MS } & 75-125 \% & \leq 20 \% & \leq 20 \% & 0.025 \mu \mathrm{g} / \mathrm{L} \\ \text { Copper } & \text { GFAA } & 75-125 \% & \leq 20 \% & \leq 20 \% & 1.0 \mu \mathrm{hg} / \mathrm{L} \\ \text { Lead } & \text { ICP/MS } & 75-125 \% & \leq 20 \% & \leq 20 \% & 0.35 \mu \mathrm{L} / \mathrm{L} \\ \text { Mercury } & \text { ICP/MS } & 75-125 \% & \leq 20 \% & \leq 20 \% & 0.35 \mu \mathrm{g} / \mathrm{L} \\ \text { Nickel } & \text { CVAF } & 75-125 \% & \leq 20 \% & \leq 20 \% & 0.002 \mu \mathrm{g} / \mathrm{L} \\ \text { Silver } & \text { ICP/MS } & 75-125 \% & \leq 20 \% & \leq 20 \% & 0.30 \mu \mathrm{h} / \mathrm{L} \\ \text { Zinc } & \text { ICP/MS } & 75-125 \% & \leq 20 \% & \leq 20 \% & 0.25 \mu \mathrm{g} / \mathrm{L} \\ & \text { GFAA } & 75-125 \% & \leq 20 \% & \leq 20 \% & 0.15 \mu \mathrm{g} / \mathrm{L}\end{array}$

METHOD

Eight metals were analyzed in water samples: silver $(\mathrm{Ag})$, cadmium $(\mathrm{Cd})$, chromium $(\mathrm{Cr})$, copper $(\mathrm{Cu})$, mercury $(\mathrm{Hg})$, nickel $(\mathrm{Ni})$, lead $(\mathrm{Pb})$ and zinc $(\mathrm{Zn})$. Hg was analyzed using cold-vapor atomic fluorescence (CVAF) according to the method of Bloom and Crecelius (1983). $\mathrm{Cr}$ and $\mathrm{Zn}$ were analyzed by graphite furnace atomic absorption (GFAA) spectrometry following the EPA Method 200.9 (EPA 1991). The remaining metals were analyzed by inductively coupled plasma mass spectrometry (ICP/MS) following a procedure based on EPA Method 200.8 (EPA 1991).

All water and elutriate samples were acidified to $\mathrm{pH}<2$ upon receipt in the laboratory. Five metals, $\mathrm{Cd}, \mathrm{Cu}, \mathrm{Pb}, \mathrm{Ni}$ and $\mathrm{Ag}$, were preconcentrated by addition of a chelating agent, which resulted in precipitation of metals from the solution. The solution was then filtered and the filter digested in concentrated acid. The digestates were then analyzed by ICP/MS as described above. 


\section{QA/QC SUMMARY/METALS (continued)}

HOLDING TIMES

DETECTION LIMITS
Water samples were received on 5/12/95 and 5/17/95 in good condition. Samples were entered into Battelle's log-in system, acidified to $\mathrm{pH}<2$ and held at ambient temperature until analysis. Mercury in water has a holding time of 28 days from collection to analysis. All samples were analyzed within this holding time. Samples were all analyzed for the remaining metals within 180 days of collection. The following table summarizes all analysis:

\begin{tabular}{ll} 
Task & Date \\
\hline APDC Extraction & $7 / 10 / 95$ \\
ICP-MS & $7 / 21 / 95$ \\
CVAA-Hg & $5 / 16$ and $5 / 31 / 95$ \\
GFAA-Cr & $5 / 22 / 95$ \\
GFAA-Zn & $5 / 23 / 95$
\end{tabular}

Target detection limits were met for all metals, except $\mathrm{Zn}$. Detection limits for $\mathrm{Zn}$ exceeded the target limits; however, all sample values were well above the detection limits achieved. Method detection limits (MDLs) for $\mathrm{Ag}, \mathrm{Cd}, \mathrm{Cu}, \mathrm{Hg}, \mathrm{Ni}$ and $\mathrm{Pb}$ were determined by spiking eight replicates of laboratory deionized water and multiplying the standard deviation of the resulting analysis by the student's tvalue at the 99th percentile $(t=2.998)$. MDLs reported for $\mathrm{Cr}$ and $\mathrm{Zn}$ were determined by taking the standard deviation of three replicate analyses of the method blank and multiplying the standard deviation by 3 .

Procedural blanks were only generated during the APDC extraction step and only analyzed for the metals that were preconcentrated $(\mathrm{Ag}$, $\mathrm{Cd}, \mathrm{Cu}, \mathrm{Ni}$ and $\mathrm{Pb}$.). The reagent blank consists of the APDC reagents only. Two reagent blanks were analyzed. $\mathrm{Pb}$ was detected in one of the reagent blanks, and Ni was detected in both of the reagent blanks. Both $\mathrm{Pb}$ and $\mathrm{Ni}$ were detected at concentrations $\geq 10$ times that of reagent contamination.

The blanks reported for $\mathrm{Hg}, \mathrm{Cr}$ and $\mathrm{Zn}$ ( the metals analyzed on waters directly) consisted of solutions, including modifiers for the $\mathrm{Zn}$ GFAA analyses, which were used to dilute all samples for analysis. $\mathrm{Zn}$ and $\mathrm{Cr}$ were detected in the blank. Both were present at less than three times the MDL. All data are corrected for the blank concentrations (or the mean of multiple blanks). 


\section{QA/QC SUMMARY/METALS (continued)}

MATRIX SPIKES

\section{REPLICATES}

SRM
Selected samples were spiked with metals at different concentrations. The APDC metals were spiked prior to sample processing, and the metals analyzed by GFAA and CVAF were spiked just prior to analysis. All recoveries were within the $\mathrm{QC}$ limits of $75 \%-125 \%$ with the exception of $\mathrm{Cd}(73 \%)$ and $\mathrm{Pb}(69 \%)$ in both APDC spikes.

Each site water sample was analyzed in triplicate. Precision for triplicate analyses is reported by calculating the relative standard deviation (RSD) between the replicate results. RSD values were all within the QC limits of $\pm 20 \%$ with the exception of Cd in three samples and $\mathrm{Ag}$ and $\mathrm{Ni}$ in one sample. Cd RSD exceedances ranged from $37 \%$ to $64 \%$ and $\mathrm{Ag}$ and $\mathrm{Ni}$ RSD exceedances were both at $21 \%$. These were primarily due to one replicate that was comparatively high, and should not affect sample precision.

SRM SLRS-3, a certified riverine water sample from the National Research Council of Canada (NRCC), was analyzed for all metals, with the exception of $\mathrm{Ag}$ and $\mathrm{Hg}$, which are not certified in this SRM. $\mathrm{Cr}, \mathrm{Cu}$ and $\mathrm{Zn}$ were recovered within $\pm 20 \%$ of mean certified value. $\mathrm{Ni}$ and $\mathrm{Pb}$ recoveries were $23 \%$ and $42 \%$, respectively. Cd was detected at over 10 times the certified value, most likely a result of SRM contamination. However, no $\mathrm{Cd}$ was detected in the APDC reagent blank; therefore, sample analyses should not be compromised.

A second SRM, 1643c, a freshwater sample from NIST, was analyzed for $\mathrm{Cr}$ and $\mathrm{Zn}$, which were recovered within the control limits of $\pm 20 \%$ of mean certified value.

In addition, $1641 \mathrm{~b}$, a freshwater sample from NIST, was analyzed twice for $\mathrm{Hg}$. Results were within $\pm 20 \%$ of mean certified value.

\section{REFERENCES}

Bloom, N. S., and E.A. Crecelius. 1983. Determination of Mercury in Seawater at SubNanogram per Liter Levels. Mar. Chem. 14:49-59.

EPA (U.S. Environmental Protecion Agency). 1991 Methods for the Determination of Metals in Environmental Samples. EPA-600/4-91-010. U.S. Environmental Protection Agency, Environmental Services Division, Monitoring Management Branch. 


\section{QA/QC SUMMARY}

PROGRAM: $\quad$ New York Federal Projects 5

PARAMETER: $\quad$ PCB Congeners/Chlorinated Pesticides

LABORATORY: Battelle/Marine Sciences Laboratory, Sequim, Washington

MATRIX: $\quad$ Site Water/Elutriate

QA/QC DATA QUALITY OBJECTIVES

\begin{tabular}{|c|c|c|c|c|}
\hline $\begin{array}{c}\text { Reference } \\
\text { Method }\end{array}$ & $\begin{array}{l}\text { Surrogate } \\
\text { Recovery }\end{array}$ & $\begin{array}{c}\text { Spike } \\
\text { Recovery }\end{array}$ & $\begin{array}{l}\text { Relative } \\
\text { Precision }\end{array}$ & $\begin{array}{l}\text { Target } \\
\text { Detection } \\
\text { Limit }\end{array}$ \\
\hline GC/ECD & $30-150 \%$ & $50-120 \%$ & $\leq 30 \%$ & $1.0 \mathrm{ng} / \mathrm{L}$ \\
\hline
\end{tabular}

METHOD

HOLDING TIMES
One liter of water was extracted with methylene chloride in a separatory funnel following a procedure based on methods used by the National Oceanic and Atmospheric Administration for its Status and Trends Program (NOAA 1993). Sample extracts were then cleaned using silica/alumina ( $5 \%$ deactivated) chromatography followed by high performance liquid chromatography (HPLC) cleanup. Extracts were analyzed for 15 chlorinated pesticides and 22 irdividiai PCB congeners using gas chromatography/electron capture detection (GC/ECD) following a procedure based on EPA Method 8080 (EPA 1986). The column used was a J\&W DB-17 and the confirmatory column was a DB-1701, both capillary columns $(30 \mathrm{~m} \times 0.25 \mathrm{~mm}$ I.D. $)$.

Water samples were received on 5/12/95 and 5/17/95 in good condition. Samples were entered into Battelle's log-in system and stored cold $\left(4^{\circ} \mathrm{C}\right)$ until extraction. Samples were extracted on $5 / 16 / 95$. Extracts were analyzed by GC/ECD from $5 / 28$ through $5 / 29 / 95$, within the established holding time of 40 days.

DETECTION LIMITS Target detection limits were met for all PCBs and pesticides. Method detection limits (MDLs) were determined by multiplying the standard deviation of seven spiked replicates of a representative clean Sequim Bay water sample by the student's $t$-value $(t=3.142)$. 


\section{QA/QC SUMMARYIPCB CONGENERS/PESTICIDES (continued)}

METHOD BLANKS

SURROGATES

MATRIX SPIKES

REPLICATES

SRAS

MISCELLANEOUS
One method blank was extracted. No PCB congeners or pesticides were detected above the MDL in the method blank.

Two compounds, PCB congeners 103 and 198, were added to all samples prior to extraction to assess the efficiency of the analysis. Sample surrogate recoveries were all within the $\mathrm{QC}$ guidelines of $30 \%-150 \%$. Note that all sample values are calculated based on the recovery of the surrogate compounds.

Five out of the 22 congeners and 11 of the 15 pesticides were spiked into one sample. Matrix spike recoveries ranged from $61 \%-110 \%$, all within the control limit range of $50 \%-120 \%$.

All samples were analyzed in triplicate. Precision was measured by calculating the relative standard deviation (RSD) between the replicate results. Only one PCB congener and only 4,4'-DDE and dieldrin were detected above the MDL. RSDs for all detectable values were below the target precision goal of $\leq 30 \%$ indicating acceptable precision with the exception of $4,4^{\prime}$-DDE $(91 \%)$ in one replicate and dieldrin (31\%) in one replicate. The high RSD value for $4,4^{\prime}$-DDE was due to matrix interference in one replicate. The elevated value reported is flagged and should be considered an estimate.

An SRM is not available for organics in water.

All congener and pesticide results are confirmed using a second dissimilar column. Results for each column must be within a factor of two of the other to be considered a confirmed value. All values were within a factor of two.

\section{REFERENCES}

NOAA (National Oceanic and Atmospheric Administration). 1993. Sampling and Analytical Methods for the National Status and Trends Program, National Benthic Surveillance and Mussel Watch Projects 1984-1992. Volume IV. Comprehensive Descriptions of Trace Organic Analytical Methods. G.G. Lauenstein and A. Y. Cantillo, eds. NOAA Technical Memorandum NOS ORCA 71. National Oceanic and Atmospheric Administration, Coastal Monitoring and Bioeffects Assessment Division, Office of Ocean Resources Conservation and Assessment, Silver Spring, Maryland.

EPA (U.S. Environmental Protection Agency). 1986. Test Methods for Evaluating Solid Waste: Physical/Chemical Methods. SW-846. U.S. Document No. 955-001-00000, U.S. Environmental Protection Agency, Washington D. C. 

Table B.1. Metals in Site Water Samples, Bronx River

\begin{tabular}{|c|c|c|c|c|c|c|c|c|c|c|}
\hline \multirow[b]{2}{*}{$\begin{array}{l}\text { Sediment } \\
\text { Treatment }\end{array}$} & \multirow[b]{2}{*}{$\begin{array}{l}\text { Analytical } \\
\text { Replicate }\end{array}$} & \multirow[b]{2}{*}{ Batch } & \multicolumn{7}{|c|}{ Concentration ( $\mu \mathrm{g} / \mathrm{L}$ ) } & \multirow[b]{2}{*}{$\begin{array}{c}\mathrm{Zn} \\
\text { GFAA }\end{array}$} \\
\hline & & & $\begin{array}{c}\mathrm{Ag} \\
\mathrm{ICP} / \mathrm{MS}\end{array}$ & $\begin{array}{c}\text { Cd } \\
\text { ICP/MS }\end{array}$ & $\begin{array}{c}\mathrm{Cr} \\
\text { GFAA }\end{array}$ & $\begin{array}{c}\mathrm{Cu} \\
\text { ICP/MS }\end{array}$ & $\begin{array}{c}\mathrm{Hg} \\
\mathrm{CVAF} \\
\end{array}$ & $\begin{array}{c}\mathrm{Ni} \\
\text { ICP/MS }\end{array}$ & $\begin{array}{c}\mathrm{Pb} \\
\mathrm{ICP} / \mathrm{MS}\end{array}$ & \\
\hline \multicolumn{3}{|c|}{ Target Detection Limit: } & 0.25 & 0.025 & 1.0 & 0.35 & 0.002 & 0.30 & 0.35 & 0.15 \\
\hline \multicolumn{3}{|c|}{ Method Detection Limit: } & 0.018 & 0.003 & 0.063 & 0.021 & 0.00007 & 0.028 & 0.011 & 0.269 \\
\hline$B X-14$ & 1 & 1 & 0.0732 & 0.0754 & 1.12 & 5.60 & 0.0162 & 1.70 & 2.88 & 19.9 \\
\hline$B X-14$ & 2 & 1 & 0.0830 & 0.0797 & 1.16 & 5.82 & 0.0162 & 1.73 & 3.19 & 20.6 \\
\hline$B X-14$ & 3 & 1 & 0.0747 & 0.0652 & 1.19 & 4.85 & 0.0136 & 1.49 & 2.77 & 20.2 \\
\hline Sequim $B a$ & Water & 1 & $0.018 U^{(a)}$ & 0.0666 & 0.69 & 0.607 & $N A^{(b)}$ & 0.455 & $0.011 U$ & 1.61 \\
\hline
\end{tabular}

ए. (a) U Undetected at or above given concentration.

$\rightarrow \quad$ (b) NA Not analyzed. 
Table B.2. Quality Control Data for Metals Analysis of Site Water Samples

\begin{tabular}{|c|c|c|c|c|c|c|c|c|c|c|}
\hline \multirow[b]{2}{*}{$\begin{array}{l}\text { Sediment } \\
\text { Treatment }\end{array}$} & \multirow[b]{2}{*}{$\begin{array}{l}\text { Analytical } \\
\text { Replicate }\end{array}$} & \multicolumn{8}{|c|}{ Concentration ( $\mu \mathrm{g} / \mathrm{L}$ ) Blank Corrected } & \multirow[b]{2}{*}{$\begin{array}{c}\mathrm{Zn} \\
\text { GFAA }\end{array}$} \\
\hline & & Batch & $\begin{array}{c}\mathrm{Ag} \\
\mathrm{ICP} / \mathrm{MS}\end{array}$ & $\begin{array}{c}\mathrm{Cd} \\
\mathrm{ICP} / \mathrm{MS}\end{array}$ & $\begin{array}{c}\mathrm{Cr} \\
\text { GFAA }\end{array}$ & $\begin{array}{c}\mathrm{Cu} \\
\text { ICP/MS }\end{array}$ & $\begin{array}{c}\mathrm{Hg} \\
\text { CVAF }\end{array}$ & $\begin{array}{c}\mathrm{Ni} \\
\mathrm{ICP} / \mathrm{MS}\end{array}$ & $\begin{array}{c}\mathrm{Pb} \\
\text { ICPMS }\end{array}$ & \\
\hline \multirow[t]{3}{*}{ Reagent Blank } & 1 & 1 & $0.018 U^{(\mathrm{a})}$ & $0.003 \mathrm{U}$ & NA (D) & $0.021 \mathrm{U}$ & NA & 0.0432 & 0.0261 & NA \\
\hline & 2 & 1 & $0.018 \mathrm{U}$ & $0.003 \mathrm{U}$ & NA & $0.021 \mathrm{U}$ & NA & 0.0301 & $0.011 \mathrm{U}$ & NA \\
\hline & Mean & & $0.018 \mathrm{U}$ & $0.003 \mathrm{U}$ & NA & $0.021 \mathrm{U}$ & NA & 0.0367 & 0.0131 & NA \\
\hline \multirow[t]{2}{*}{ Direct Blank } & 1 & 1 & NA & NA & 0.108 & NA & 0.000384 & NA & NA & 0.63 \\
\hline & 2 & 1 & NA & NA & NA & NA & 0.000355 & NA & NA & NA \\
\hline
\end{tabular}

Matrix Spike Results

$\mathrm{SH}-8^{(c)}$

$\mathrm{SH}-8$ (MS)

Mean $1 \quad$ NS ${ }^{(0)} \quad$ NS 3.72

Concentration Spiked

Mean 1 NS ${ }^{(d)} \quad$ NS

3.72 NS NS

Concentration Recovered

Percent Recovery

NS NS

4.81

0.97

1.09

NS NS

NS

NS

NS

NS NS

112

$\infty$

in $S R-4^{(0)}$

SR-4 (MS)

Concentration Spiked

Concentration Recovered

Percent Recovery

Sequim Bay SW

Sequim Bay SW (MS)

Concentration Spiked

Concentration Recovered

Percent Recovery

\begin{tabular}{|c|c|c|}
\hline 1 & NS & NS \\
\hline \multirow[t]{4}{*}{1} & NS & NS \\
\hline & NS & NS \\
\hline & NS & NS \\
\hline & NS & NS \\
\hline 1 & $0.018 U$ & 0.0666 \\
\hline \multirow[t]{4}{*}{1} & 0.880 & 0.793 \\
\hline & 1.00 & 1.00 \\
\hline & 0.880 & 0.726 \\
\hline & 88 & 73 \\
\hline 1 & $0.018 \mathrm{U}$ & 0.0666 \\
\hline \multirow[t]{4}{*}{1} & 0.821 & 0.89 \\
\hline & 1.00 & 1.00 \\
\hline & 0.821 & 0.823 \\
\hline & 82 & 82 \\
\hline
\end{tabular}

NS
$N S$
$N S$
$N S$
$N S$
NS
$N S$
$N S$
$N S$
$N S$
NS
$N S$
$N S$
$N S$
$N S$

NS

NS NS

NS

NS NS

NS NS

NS NS

NS NS

NS

NS

NS

NS NS

NS NS

Sequim Bay SW

Sequim Bay SW (MS)

Concentration Spiked

Concentration Recovered

82

82

$\begin{array}{rr}\text { NS } & 0.0101 \\ \text { NS } & 0.0342 \\ \text { NS } & 0.0207 \\ \text { NS } & 0.0241 \\ \text { NS } & 116 \\ & \cdot \\ 0.607 & \text { NS } \\ 1.52 & \text { NS } \\ 1.00 & \text { NS } \\ 0.913 & \text { NS } \\ 91 & \text { NS } \\ & \\ 0.607 & \text { NS } \\ 1.53 & \text { NS } \\ 1.00 & \text { NS } \\ 0.923 & \text { NS } \\ 92 & \text { NS }\end{array}$

$\begin{array}{rcr}N S & N S & 8.40 \\ N S & N S & 16.8 \\ N S & N S & 8.91 \\ N S & N S & 8.38 \\ N S & N S & 94 \\ & & \\ 0.455 & 0.011 \cup & N S \\ 1.31 & 0.694 & N S \\ 1.00 & 1.00 & N S \\ 0.858 & 0.694 & N S \\ 86 & 69^{(0)} & N S \\ & & \\ 0.455 & 0.011 U & N S \\ 1.24 & 0.691 & N S \\ 1.00 & 1.00 & N S \\ 0.788 & 0.691 & N S \\ 79 & 69^{(0)} & N S\end{array}$


Table B.2. (contd)

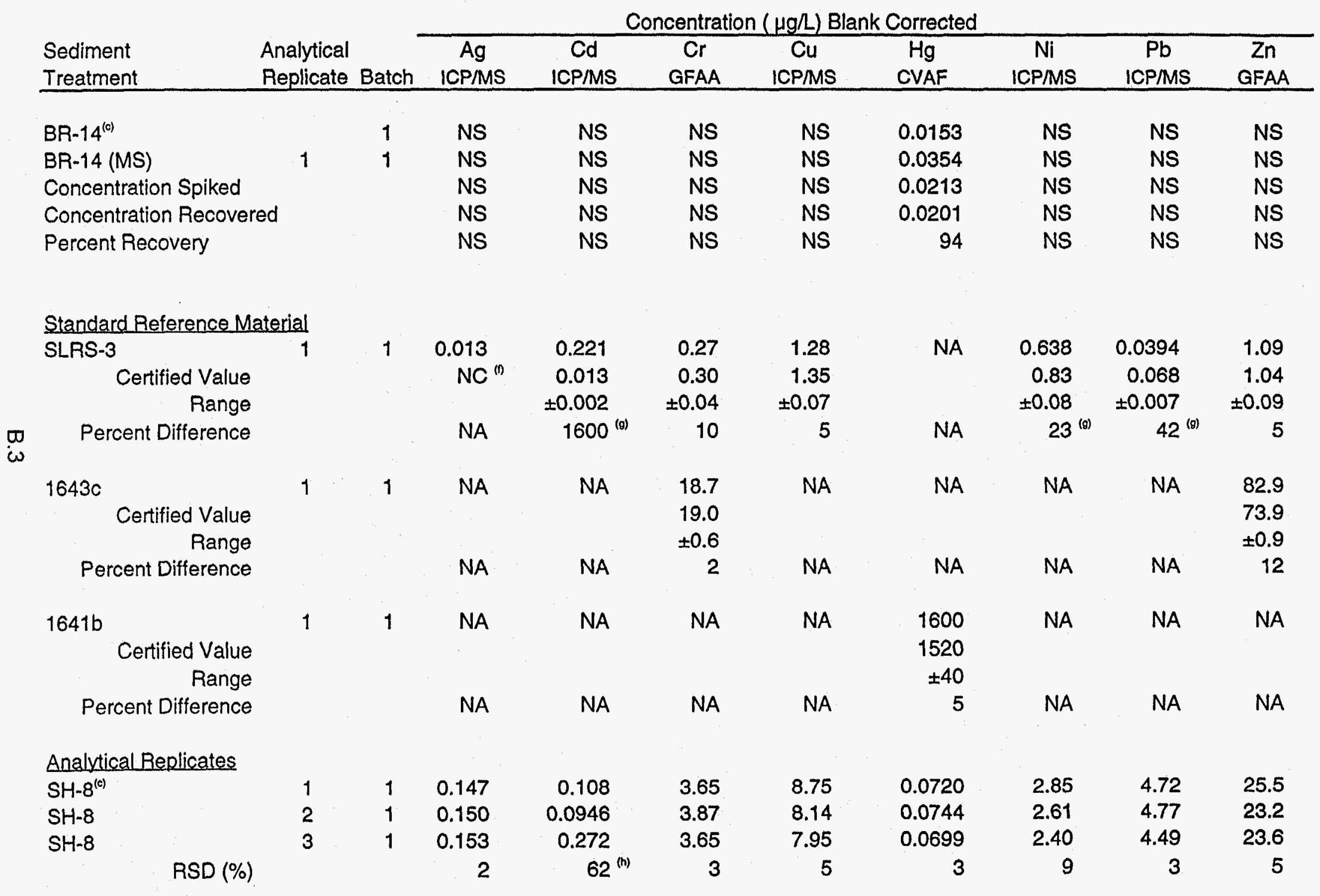


Table B.2. (contd)

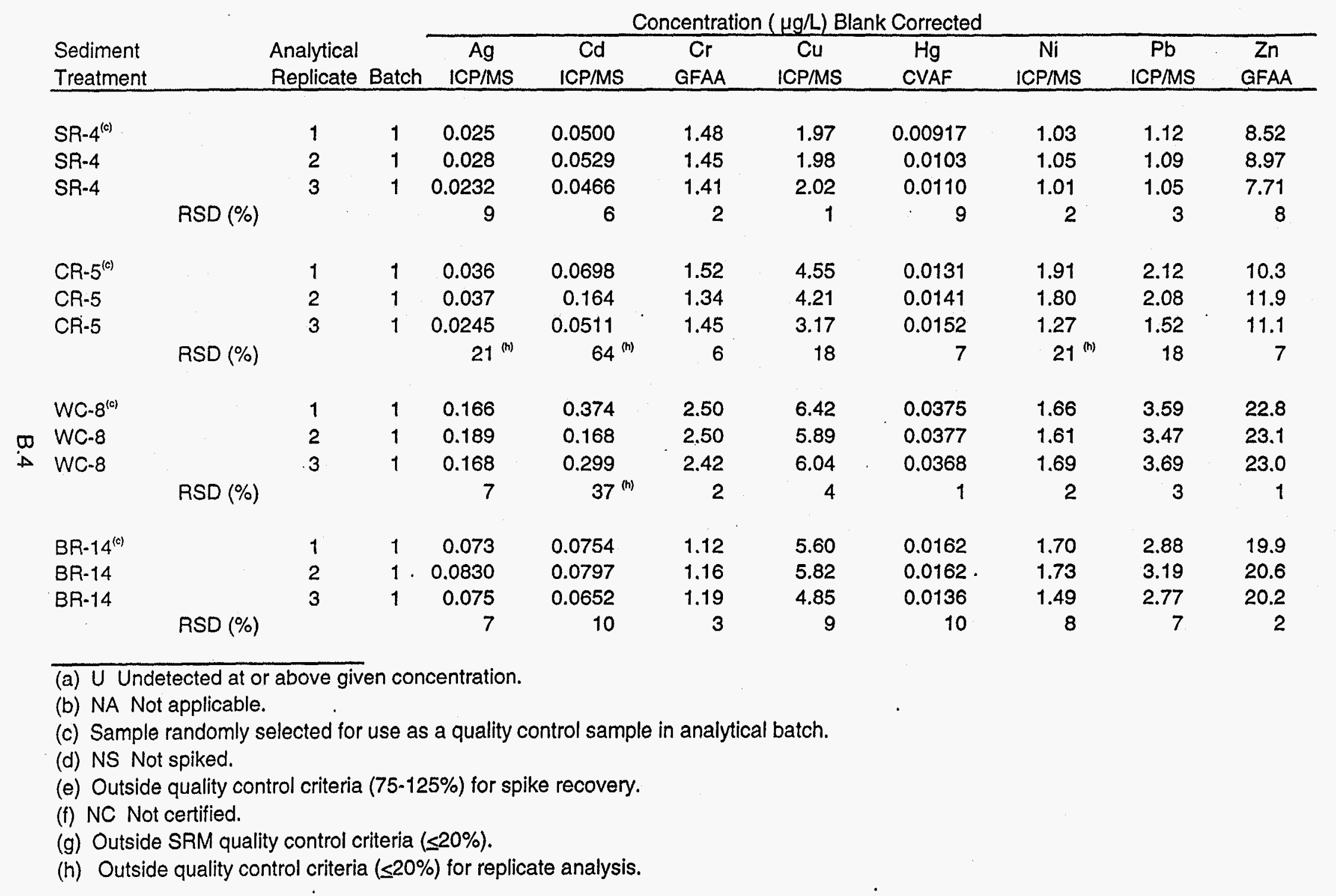


Table B.3. Metals in Elutriate Samples, Bronx River

\begin{tabular}{|c|c|c|c|c|c|c|c|c|c|c|}
\hline \multirow[b]{2}{*}{$\begin{array}{l}\text { Sediment } \\
\text { Treatment }\end{array}$} & \multirow[b]{2}{*}{$\begin{array}{l}\text { Analytical } \\
\text { Replicate }\end{array}$} & \multirow[b]{2}{*}{ Batch } & \multicolumn{8}{|c|}{ Concentration $(\mu g / L)$} \\
\hline & & & $\begin{array}{c}\mathrm{Ag} \\
\mathrm{ICP} / \mathrm{MS}\end{array}$ & $\begin{array}{c}\mathrm{Cd} \\
\text { ICP/MS }\end{array}$ & $\begin{array}{c}\mathrm{Cr} \\
\text { GFAA }\end{array}$ & $\begin{array}{c}\mathrm{Cu} \\
\mathrm{ICP} / \mathrm{MS}\end{array}$ & $\begin{array}{c}\mathrm{Hg} \\
\text { CVAF }\end{array}$ & $\begin{array}{c}\mathrm{Ni} \\
\text { ICP/MS }\end{array}$ & $\begin{array}{c}\mathrm{Pb} \\
\text { ICPMS }\end{array}$ & $\begin{array}{c}\mathrm{Zn} \\
\text { GFAA }\end{array}$ \\
\hline & ction Limit: & & 0.25 & 0.025 & 1.0 & 0.35 & 0.002 & 0.30 & 0.35 & 0.15 \\
\hline & ction Limit: & & 0.018 & 0.003 & 0.082 & 0.0210 & 0.00005 & 0.03 & 0.011 & 0.272 \\
\hline BX COMP & 1 & 1 & 0.0601 & 0.0571 & 1.24 & 4.47 & 0.0159 & 1.22 & 2.33 & 8.25 \\
\hline BX COMP & 2 & 1 & 0.132 & 0.0542 & 1.26 & 4.54 & 0.0138 & 1.20 & 2.48 & 9.15 \\
\hline BX COMP & 3 & 1 & 0.0666 & 0.0463 & 1.13 & 4.62 & 0.0143 & 1.00 & 1.88 & 6.98 \\
\hline
\end{tabular}


Table B.4. Quality Control Data for Metals Analysis of Elutriate Samples

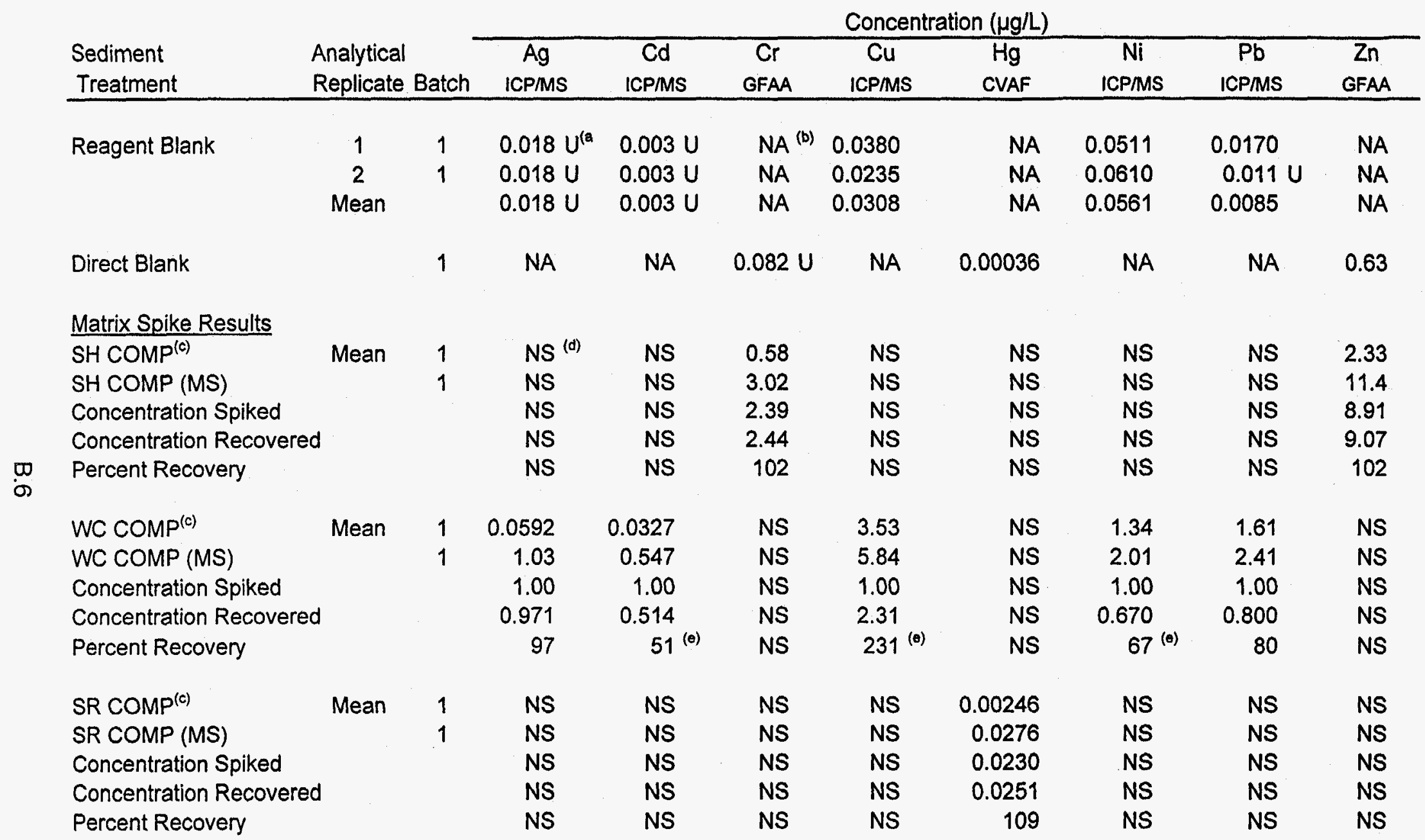


Table B.4. (contd)

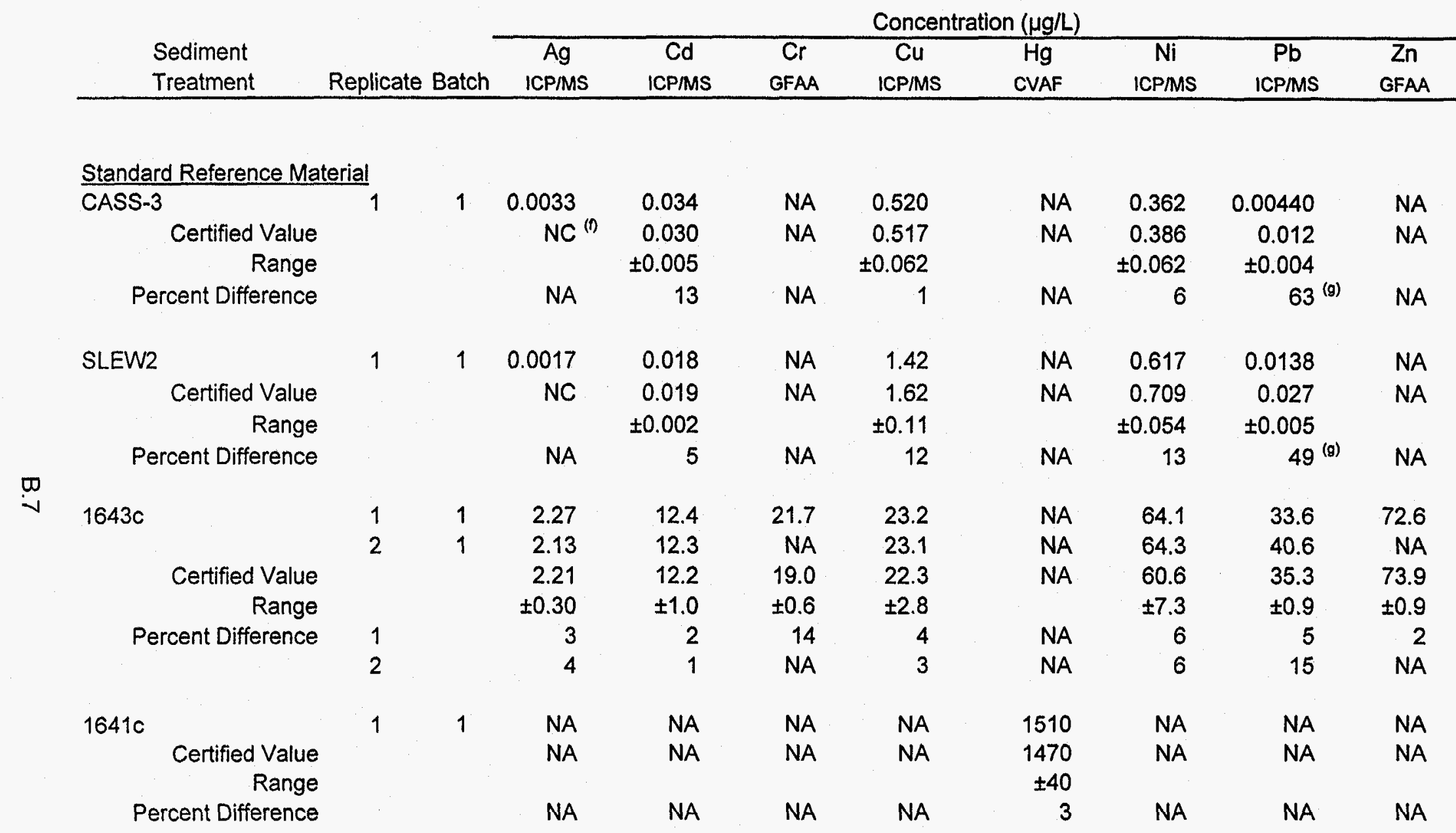


Table B.4. (contd)

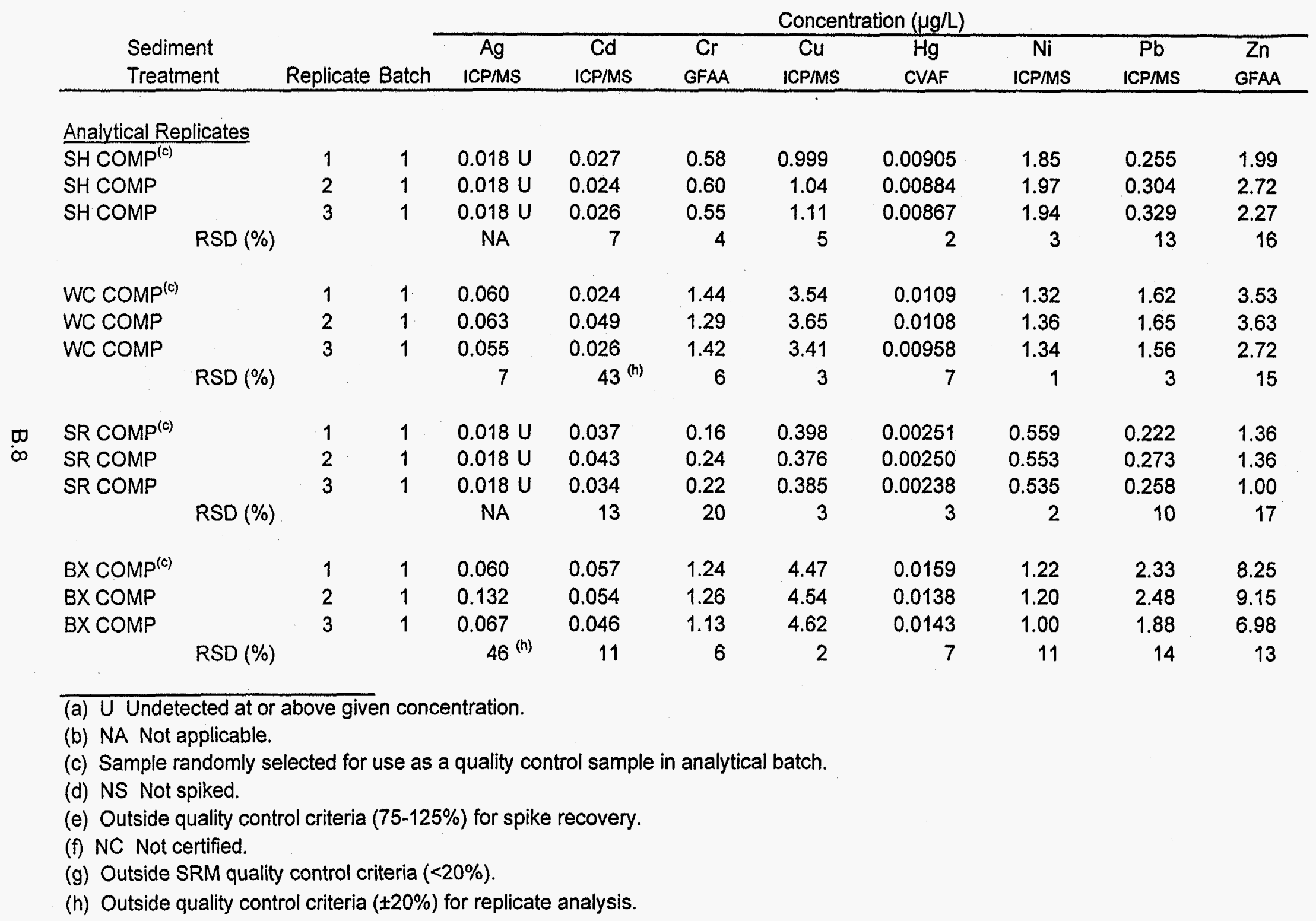


Table B.5. Pesticides and Polychlorinated Biphenyls (PCBs)

in Site Water Samples, Bronx River

\begin{tabular}{|c|c|c|c|c|}
\hline \multirow[b]{2}{*}{ Sediment Treatment } & \multicolumn{4}{|c|}{ Concentration (ng/L) } \\
\hline & $\mathrm{BX}-14$ & $B X-14$ & $B X-14$ & Sequim Bay Water \\
\hline Replicate & 1 & 2 & 3 & 1 \\
\hline Sample Size (L) & 1.07 & 1.07 & 1.07 & 1.00 \\
\hline Batch & 1 & 1 & 1 & 1 \\
\hline $2,4^{\prime}-\mathrm{DDD}^{(\mathrm{a})}$ & $0.93 U^{(b)}$ & $0.93 \mathrm{U}$ & $0.93 \mathrm{U}$ & $1.00 \mathrm{U}$ \\
\hline 2,4'-DDE & $0.23 \mathrm{U}$ & $0.23 \mathrm{U}$ & $0.23 U$ & $0.24 \mathrm{U}$ \\
\hline 2,4'-DDT & $0.43 \mathrm{U}$ & $0.43 U$ & $0.43 U$ & $0.46 \mathrm{U}$ \\
\hline 4,4'-DDD & $0.44 \mathrm{U}$ & $0.44 \mathrm{U}$ & 4.71 & $0.48 \mathrm{U}$ \\
\hline $4,4^{\prime}-\mathrm{DDE}$ & 2.63 & 2.35 & 3.48 & $0.29 \mathrm{U}$ \\
\hline 4,4'-DDT & $0.40 \mathrm{U}$ & $0.40 \mathrm{U}$ & 4.79 & $0.43 \mathrm{U}$ \\
\hline$\alpha$-Chlordane & $0.82 U$ & $0.82 \mathrm{U}$ & $0.82 U$ & $0.88 \mathrm{U}$ \\
\hline Aldrin & $0.38 \mathrm{U}$ & $0.38 \mathrm{U}$ & $0.38 \mathrm{U}$ & $0.41 \mathrm{U}$ \\
\hline Dieldrin & 2.77 & 2.82 & 4.62 & $0.13 \mathrm{U}$ \\
\hline Endosulfan I & $0.46 \mathrm{U}$ & $0.46 \mathrm{U}$ & $0.46 U$ & $0.49 \mathrm{U}$ \\
\hline Endosulfan II & $0.46 \mathrm{U}$ & $0.46 U$ & $0.46 \mathrm{U}$ & $0.49 \mathrm{U}$ \\
\hline Endosulfan Sulfate & $0.46 \mathrm{U}$ & $0.46 U$ & $0.46 \mathrm{U}$ & $0.49 \mathrm{U}$ \\
\hline Heptachlor & $0.46 \mathrm{U}$ & $0.46 \mathrm{U}$ & $0.46 \mathrm{U}$ & $0.50 \mathrm{U}$ \\
\hline Heptachlor Epoxide & $0.11 \mathrm{U}$ & $0.11 \mathrm{U}$ & 1.52 & $0.12 \mathrm{U}$ \\
\hline Trans Nonachlor & $1.10 \mathrm{U}$ & $1.10 \mathrm{U}$ & $1.10 \mathrm{U}$ & $1.18 \mathrm{U}$ \\
\hline PCB 8 & $0.98 U$ & $0.98 \mathrm{U}$ & $0.98 \mathrm{U}$ & $1.06 \mathrm{U}$ \\
\hline PCB 18 & 1.54 & $1.04 \mathrm{U}$ & $1.04 \mathrm{U}$ & $1.12 \mathrm{U}$ \\
\hline PCB 28 & $0.70 \mathrm{U}$ & $0.70 \mathrm{U}$ & $0.70 \mathrm{U}$ & $0.75 \mathrm{U}$ \\
\hline PCB 44 & $0.30 \mathrm{U}$ & $0.30 \mathrm{U}$ & $0.30 \mathrm{U}$ & $0.33 \mathrm{U}$ \\
\hline PCB 49 & $0.53 \mathrm{U}$ & $0.53 \mathrm{U}$ & $0.53 \mathrm{U}$ & $0.57 \mathrm{U}$ \\
\hline PCB 52 & $0.35 \mathrm{U}$ & $0.35 \mathrm{U}$ & $0.35 \mathrm{U}$ & $0.38 \mathrm{U}$ \\
\hline PCB 66 & $0.38 \mathrm{U}$ & $0.38 \mathrm{U}$ & $0.38 \mathrm{U}$ & $0.41 \mathrm{U}$ \\
\hline PCB 87 & $0.35 \mathrm{U}$ & $0.35 U$ & $0.35 \mathrm{U}$ & $0.38 \cup$ \\
\hline PCB 101 & $0.48 \mathrm{U}$ & $0.48 \mathrm{U}$ & $0.48 \mathrm{U}$ & $0.52 U$ \\
\hline PCB 105 & $0.29 \mathrm{U}$ & $0.29 \mathrm{U}$ & $0.29 \mathrm{U}$ & $0.32 \mathrm{U}$ \\
\hline PCB 118 & $0.46 \mathrm{U}$ & $0.46 \mathrm{U}$ & $0.46 \mathrm{U}$ & $0.50 \mathrm{U}$ \\
\hline PCB 128 & $0.24 \mathrm{U}$ & $0.24 \mathrm{U}$ & $0.24 \mathrm{U}$ & $0.26 U$ \\
\hline PCB 138 & $0.34 \mathrm{U}$ & $0.34 \mathrm{U}$ & $0.34 \mathrm{U}$ & $0.36 \mathrm{U}$ \\
\hline PCB 153 & 0.44 & 0.41 & 0.44 & $0.42 \mathrm{U}$ \\
\hline PCB 170 & $0.20 \mathrm{U}$ & $0.20 \mathrm{U}$ & $0.20 \mathrm{U}$ & $0.21 \mathrm{U}$ \\
\hline PCB 180 & $0.27 \mathrm{U}$ & $0.27 \mathrm{U}$ & $0.27 \mathrm{U}$ & $0.29 \mathrm{U}$ \\
\hline РCВ 183 & $0.53 \cup$ & $0.53 \mathrm{U}$ & $0.53 \mathrm{U}$ & $0.57 \mathrm{U}$ \\
\hline PCB 184 & $0.53 \cup$ & $0.53 \mathrm{U}$ & $0.53 \mathrm{U}$ & $0.57 \mathrm{U}$ \\
\hline PCB 187 & $0.38 \mathrm{U}$ & $0.38 \mathrm{U}$ & $0.38 \mathrm{U}$ & $0.41 \mathrm{U}$ \\
\hline PCB 195 & $0.27 \mathrm{U}$ & $0.27 \mathrm{U}$ & $0.27 \mathrm{U}$ & $0.29 \mathrm{U}$ \\
\hline PCB 206 & $0.39 \mathrm{U}$ & $0.39 \mathrm{U}$ & $0.39 \mathrm{U}$ & $0.42 U$ \\
\hline PCB 209 & $0.27 \mathrm{U}$ & $0.27 \mathrm{U}$ & $0.27 \mathrm{U}$ & $0.29 \mathrm{U}$ \\
\hline \multicolumn{5}{|c|}{ Surrogate Recoveries (\%) } \\
\hline PCB 103 (SIS) & 81 & 82 & 86 & 75 \\
\hline PCB 198 (SIS) & 127 & 121 & 126 & 85 \\
\hline
\end{tabular}

(a) Target detection limits range from $0.5 \mathrm{ng} / \mathrm{L}$ to $100 \mathrm{ng} / \mathrm{L}$ for all analytes.

(b) $\mathrm{U}$ Undetected at or above given concentration. 
Table B.6. Quality Control Data for Pesticide and Polychlorinated Biphenyl (PCB) Analysis in Site Water

\begin{tabular}{|c|c|c|c|c|c|c|}
\hline \multirow{5}{*}{$\begin{array}{l}\text { Sediment Treatment } \\
\text { Replicate } \\
\text { Sample Size (L) } \\
\text { Batch }\end{array}$} & \multirow{5}{*}{$\begin{array}{c}\text { Method Blank } \\
1 \\
1.00 \\
1 \\
\end{array}$} & \multicolumn{5}{|c|}{ Matrix Spike Results } \\
\hline & & \multirow{4}{*}{$\begin{array}{c}\text { Sequim Bay Water } \\
1 \\
1.00 \\
1\end{array}$} & \multicolumn{3}{|c|}{ Concentration (ng/L) } & \multirow{4}{*}{$\begin{array}{l}\text { Percent } \\
\text { Recovery }\end{array}$} \\
\hline & & & Sequim Bay Water & \multicolumn{2}{|c|}{ Concentration } & \\
\hline & & & (MS) & Spiked & Recovered & \\
\hline & & & 1 & & & \\
\hline $2,4^{\prime}-\mathrm{DDD}$ & $1.00 \mathrm{U}^{(a)}$ & $1.00 \mathrm{U}$ & $\mathrm{NS}^{\text {(b) }}$ & NS & $N A^{(c)}$ & NA \\
\hline 2,4'-DDE & $0.24 \mathrm{U}$ & $0.24 \mathrm{U}$ & NS & NS & NA & NA \\
\hline 2,4'-DDT & $0.46 \mathrm{U}$ & $0.46 \mathrm{U}$ & NS & NS & NA & NA \\
\hline 4,4'-DDD & $0.48 \mathrm{U}$ & $0.48 \mathrm{U}$ & 12.3 & 12.5 & 12.3 & 98 \\
\hline 4,4'-DDE & $0.29 \mathrm{U}$ & $0.29 \mathrm{U}$ & 10.4 & 12.5 & 10.4 & 83 \\
\hline 4,4'-DDT & $0.43 U$ & $0.43 \mathrm{U}$ & 13.0 & 12.5 & 13.0 & 104 \\
\hline$\alpha$-Chlordane & $0.88 \mathrm{U}$ & $0.88 \mathrm{U}$ & 8.83 & 12.5 & 8.83 & 71 \\
\hline Aldrin & $0.41 \mathrm{U}$ & $0.41 \mathrm{U}$ & 7.68 & 12.5 & 7.68 & 61 \\
\hline Dieldrin & $0.13 \mathrm{U}$ & $0.13 \mathrm{U}$ & 11.6 & 12.5 & 11.6 & 93 \\
\hline Endosulfan 1 & $0.49 \mathrm{U}$ & $0.49 U$ & 11.3 & 12.5 & 11.3 & 91 \\
\hline Endosulfan II & $0.49 \mathrm{U}$ & $0.49 \mathrm{U}$ & 11.7 & 12.5 & 11.7 & 93 \\
\hline Endosulfan Sulfate & $0.49 \mathrm{U}$ & $0.49 \mathrm{U}$ & 13.3 & 12.5 & 13.3 & 106 \\
\hline Heptachlor & $0.50 \mathrm{U}$ & $0.50 \mathrm{U}$ & 8.44 & 12.5 & 8.44 & 68 \\
\hline Heptachlor Epoxide & $0.12 \mathrm{U}$ & $0.12 U$ & 11.6 & 12.5 & 11.6 & 93 \\
\hline Trans Nonachlor & $1.18 \mathrm{U}$ & $1.18 \mathrm{U}$ & NS & NS & NA & NA \\
\hline РCB 8 & $1.06 \mathrm{U}$ & $1.06 U$ & NS & NS & NA & NA \\
\hline РСВ 18 & $1.12 \mathrm{U}$ & $1.12 \mathrm{U}$ & NS & NS & NA & NA \\
\hline РCB 28 & $0.75 \mathrm{U}$ & $0.75 \mathrm{U}$ & 17.5 & 15.9 & 17.5 & 110 \\
\hline РCB 44 & $0.33 \mathrm{U}$ & $0.33 \mathrm{U}$ & NS & NS & NA & NA \\
\hline РСB 49 & $0.57 \mathrm{U}$ & $0.57 \mathrm{U}$ & NS & NS & NA & NA \\
\hline РСВ 52 & $0.38 \mathrm{U}$ & $0.38 \mathrm{U}$ & 32.4 & 32.3 & 32.4 & 101 \\
\hline РСB 66 & $0.41 \mathrm{U}$ & $0.41 U^{*}$ & NS & NS & NA & NA \\
\hline РСВ 87 & $0.38 \mathrm{U}$ & $0.38 \mathrm{U}$ & NS & NS & NA & NA \\
\hline PCB 101 & $0.52 \mathrm{U}$ & $0.52 U$ & 24.9 & 22.6 & 24.9 & 110 \\
\hline PCB 105 & $0.32 \mathrm{U}$ & $0.32 \mathrm{U}$ & NS & NS & NA & NA \\
\hline РCB 118 & $0.50 \mathrm{U}$ & $0.50 \mathrm{U}$ & NS & NS & NA & NA \\
\hline PCB 128 & $0.26 \mathrm{U}$ & $0.26 \mathrm{U}$ & NS & NS & NA & NA \\
\hline PCB 138 & $0.36 U$ & $0.36 \mathrm{U}$ & 10.6 & 10.2 & 10.6 & 104 \\
\hline PCB 153 & $0.42 U$ & $0.42 \mathrm{U}$ & 13.8 & 13.2 & 13.8 & 105 \\
\hline PCB 170 & $0.21 \mathrm{U}$ & $0.21 \mathrm{U}$ & NS & NS & NA & NA \\
\hline PCB 180 & $0.29 \mathrm{U}$ & $0.29 \mathrm{U}$ & NS & NS & NA & NA \\
\hline PCB 183 & $0.57 \mathrm{U}$ & $0.57 \mathrm{U}$ & NS & NS & NA & NA \\
\hline PCB 184 & $0.57 U$ & $0.57 U$ & NS & NS & NA & NA \\
\hline PCB 187 & $0.41 \mathrm{U}$ & $0.41 \mathrm{U}$ & NS & NS & NA & NA \\
\hline РСВ 195 & $0.29 \mathrm{U}$ & $0.29 \mathrm{U}$ & NS & NS & NA & NA \\
\hline PCB 206 & $0.42 U$ & $0.42 \mathrm{U}$ & NS & NS & NA & NA \\
\hline РСВ 209 & $0.29 \mathrm{U}$ & $0.29 \mathrm{U}$ & NS & NS & NA & NA \\
\hline \multicolumn{7}{|c|}{ Surrogate Recoveries (\%) } \\
\hline PCB 103 (SIS) & 77 & 75 & 92 & NA & NA & NA \\
\hline PCB 198 (SIS) & 92 & 85 & 92 & NA & NA & NA \\
\hline
\end{tabular}


Table B.6. (contd)

Analytical Replicates

\begin{tabular}{|c|c|c|c|c|c|c|c|c|}
\hline \multirow{5}{*}{$\begin{array}{l}\text { Sediment Treatment } \\
\text { Replicate } \\
\text { Sample Size (L) } \\
\text { Batch }\end{array}$} & \multirow{2}{*}{\multicolumn{3}{|c|}{ Concentration (ng/L) }} & \multirow{5}{*}{$\begin{array}{c}\text { RSD } \\
(\%)\end{array}$} & \multirow{2}{*}{\multicolumn{3}{|c|}{ Concentration (ng/L) }} & \\
\hline & & & & & & & & \multirow{4}{*}{$\begin{array}{l}\text { RSD } \\
(\%)\end{array}$} \\
\hline & $\begin{array}{c}\mathrm{SH}-8^{(0)} \\
1\end{array}$ & $\begin{array}{c}\mathrm{SH}-8 \\
2\end{array}$ & $\begin{array}{c}\mathrm{SH}-8 \\
3\end{array}$ & & $\begin{array}{c}\mathrm{SR}-4^{(0)} \\
1\end{array}$ & $\begin{array}{c}\text { SR-4 } \\
2\end{array}$ & SR-4 & \\
\hline & 1.04 & 1.07 & 1.07 & & 1.07 & 1.07 & 1.07 & \\
\hline & 1 & 1 & 1 & & 1 & 1 & 1 & \\
\hline 2,4 '-DDD & $0.96 \mathrm{U}$ & $0.93 \mathrm{U}$ & $0.93 \mathrm{U}$ & NA & $0.93 \mathrm{U}$ & $0.93 \mathrm{U}$ & $0.94 \mathrm{U}$ & NA \\
\hline 2,4'-DDE & $0.24 \mathrm{U}$ & $0.23 \mathrm{U}$ & $0.23 \mathrm{U}$ & NA & $0.23 \mathrm{U}$ & $0.23 U$ & $0.23 \mathrm{U}$ & NA \\
\hline 2,4'-DDT & $0.44 \mathrm{U}$ & $0.43 \mathrm{U}$ & $0.43 \mathrm{U}$ & NA & $0.43 \mathrm{U}$ & $0.43 \mathrm{U}$ & $0.44 \mathrm{U}$ & NA \\
\hline 4,4'-DDD & $0.46 U$ & $0.44 \mathrm{U}$ & $0.44 \mathrm{U}$ & NA & $0.44 U$ & $0.44 \mathrm{U}$ & $0.45 \mathrm{U}$ & NA \\
\hline 4,4'-DDE & 2.99 & 3.17 & $13.3^{(\theta)}$ & $91^{(i)}$ & 2.50 & 3.45 & 2.72 & 17 \\
\hline 4,4'-DDT & $0.41 \mathrm{U}$ & $0.40 \mathrm{U}$ & $0.40 \mathrm{U}$ & NA & $0.40 \mathrm{U}$ & $0.40 \mathrm{U}$ & $0.40 \mathrm{U}$ & NA \\
\hline$\alpha$-Chlordane & $0.84 \mathrm{U}$ & $0.82 \mathrm{U}$ & $0.82 \mathrm{U}$ & NA & $0.82 \mathrm{U}$ & $0.82 \mathrm{U}$ & $0.83 \mathrm{U}$ & NA \\
\hline Aldrin & $0.40 \mathrm{U}$ & $0.38 \mathrm{U}$ & $0.38 \mathrm{U}$ & NA & $0.38 \mathrm{U}$ & $0.38 \mathrm{U}$ & $0.39 \mathrm{U}$ & NA \\
\hline Dieldrin & $0.13 \mathrm{U}$ & $0.12 \mathrm{U}$ & $0.12 U$ & NA & $0.12 \mathrm{U}$ & $0.12 \mathrm{U}$ & $0.12 \mathrm{U}$ & NA \\
\hline Endosulfan I & $0.47 \mathrm{U}$ & $0.46 \mathrm{U}$ & $0.46 \mathrm{U}$ & NA & $0.46 \mathrm{U}$ & $0.46 \mathrm{U}$ & $0.46 U$ & NA \\
\hline Endosulfan II & $0.47 \mathrm{U}$ & $0.46 \mathrm{U}$ & $0.46 \mathrm{U}$ & NA & $0.46 \mathrm{U}$ & $0.46 U$ & $0.46 \mathrm{U}$ & NA \\
\hline Endosulfan Sulfate & $0.47 \mathrm{U}$ & $0.46 \mathrm{U}$ & $0.46 \mathrm{U}$ & NA & $0.46 \mathrm{U}$ & $0.46 \mathrm{U}$ & $0.46 \mathrm{U}$ & NA \\
\hline Heptachlor & $0.48 \mathrm{U}$ & $0.46 \mathrm{U}$ & $0.46 \mathrm{U}$ & NA & $0.46 \mathrm{U}$ & $0.46 \mathrm{U}$ & $0.47 \mathrm{U}$ & NA \\
\hline Heptachlor Epoxide & $0.11 \mathrm{U}$ & $0.11 \mathrm{U}$ & $0.11 \mathrm{U}$ & NA & $0.11 \mathrm{U}$ & $0.11 \mathrm{U}$ & $0.11 \mathrm{U}$ & NA \\
\hline Trans Nonachlor & $1.13 \mathrm{U}$ & $1.10 \mathrm{U}$ & $1.10 \mathrm{U}$ & NA & $1.10 \mathrm{U}$ & $1.10 \mathrm{U}$ & $1.11 \mathrm{U}$ & NA \\
\hline РCB 8 & $1.02 \mathrm{U}$ & $0.98 \mathrm{U}$ & $0.98 \mathrm{U}$ & NA & $0.98 \mathrm{U}$ & $0.98 \mathrm{U}$ & $1.00 \mathrm{U}$ & NA \\
\hline РCB 18 & $1.08 \mathrm{U}$ & $1.04 \mathrm{U}$ & $1.04 \mathrm{U}$ & NA & $1.04 \mathrm{U}$ & $1.04 \mathrm{U}$ & $1.05 \mathrm{U}$ & NA \\
\hline PCB 28 & $0.72 \mathrm{U}$ & $0.70 \mathrm{U}$ & $0.70 \mathrm{U}$ & NA & $0.70 \mathrm{U}$ & $0.70 \mathrm{U}$ & $0.71 \mathrm{U}$ & NA \\
\hline PCB 44 & $0.31 \mathrm{U}$ & $0.30 \mathrm{U}$ & $0.30 \mathrm{U}$ & NA & $0.30 \mathrm{U}$ & $0.30 \mathrm{U}$ & $0.31 \mathrm{U}$ & NA \\
\hline PCB 49 & $0.55 \mathrm{U}$ & $0.53 U$ & $0.53 \mathrm{U}$ & NA & $0.53 \mathrm{U}$ & $0.53 \mathrm{U}$ & $0.53 \mathrm{U}$ & NA \\
\hline РCB 52 & $0.36 \mathrm{U}$ & $0.35 \mathrm{U}$ & $0.35 \mathrm{U}$ & NA & $0.35 \mathrm{U}$ & $0.35 \mathrm{U}$ & $0.35 \mathrm{U}$ & NA \\
\hline PCB 66 & $0.39 \mathrm{U}$ & $0.38 \mathrm{U}$ & $0.38 \mathrm{U}$ & NA & $0.38 \mathrm{U}$ & $0.38 \mathrm{U}$ & $0.38 U$ & NA \\
\hline PCB 87 & $0.36 \mathrm{U}$ & $0.35 \mathrm{U}$ & $0.35 \mathrm{U}$ & NA & $0.35 \mathrm{U}$ & $0.35 \mathrm{U}$ & $0.35 \mathrm{U}$ & NA \\
\hline PCB 101 & $0.50 \mathrm{U}$ & $0.48 \mathrm{U}$ & $0.48 \mathrm{U}$ & NA & $0.48 \mathrm{U}$ & $0.48 \mathrm{U}$ & $0.48 \mathrm{U}$ & NA \\
\hline PCB 105 & $0.30 \mathrm{U}$ & $0.29 \mathrm{U}$ & $0.29 \mathrm{U}$ & NA & $0.29 \mathrm{U}$ & $0.29 \mathrm{U}$ & $0.30 \mathrm{U}$ & NA \\
\hline PCB 118 & $0.48 \mathrm{U}$ & $0.46 \mathrm{U}$ & $0.46 \mathrm{U}$ & NA & $0.46 \mathrm{U}$ & $0.46 \mathrm{U}$ & $0.47 \mathrm{U}$ & NA \\
\hline РCB 128 & $0.25 \mathrm{U}$ & $0.24 \mathrm{U}$ & $0.24 \mathrm{U}$ & NA & $0.24 \mathrm{U}$ & $0.24 \mathrm{U}$ & $0.24 \mathrm{U}$ & NA \\
\hline PCB 138 & $0.35 \mathrm{U}$ & $0.34 \mathrm{U}$ & $0.34 \mathrm{U}$ & NA & $0.34 \mathrm{U}$ & $0.34 U$ & $0.34 \mathrm{U}$ & NA \\
\hline PCB 153 & $0.40 \mathrm{U}$ & $0.39 \mathrm{U}$ & $0.39 \mathrm{U}$ & NA & $0.39 \mathrm{U}$ & $0.39 \mathrm{U}$ & $0.39 \mathrm{U}$ & NA \\
\hline PCB 170 & $0.20 \mathrm{U}$ & $0.20 \mathrm{U}$ & $0.20 \mathrm{U}$ & NA & $0.20 \mathrm{U}$ & $0.20 \mathrm{U}$ & $0.20 \mathrm{U}$ & NA \\
\hline РСВ 180 & $0.28 \mathrm{U}$ & $0.27 \mathrm{U}$ & $0.27 \mathrm{U}$ & NA & $0.27 \mathrm{U}$ & $0.27 \mathrm{U}$ & $0.27 \mathrm{U}$ & NA \\
\hline PCB 183 & $0.55 \mathrm{U}$ & $0.53 \mathrm{U}$ & $0.53 \mathrm{U}$ & NA & $0.53 \mathrm{U}$ & $0.53 \mathrm{U}$ & $0.53 \mathrm{U}$ & NA \\
\hline PCB 184 & $0.55 U$ & $0.53 \mathrm{U}$ & $0.53 \mathrm{U}$ & NA & $0.53 U$ & $0.53 \mathrm{U}$ & $0.53 \mathrm{U}$ & NA \\
\hline PCB 187 & $0.39 \mathrm{U}$ & $0.38 \mathrm{U}$ & $0.38 \mathrm{U}$ & NA & $0.38 U$ & $0.38 \mathrm{U}$ & $0.39 \mathrm{U}$ & NA \\
\hline PCB 195 & $0.28 \mathrm{U}$ & $0.27 \mathrm{U}$ & $0.27 \mathrm{U}$ & NA & $0.27 \mathrm{U}$ & $0.27 \mathrm{U}$ & $0.27 \mathrm{U}$ & NA \\
\hline PCB 206 & $0.40 \mathrm{U}$ & $0.39 \mathrm{U}$ & $0.39 \mathrm{U}$ & NA & $0.39 \mathrm{U}$ & $0.39 \mathrm{U}$ & $0.39 \mathrm{U}$ & NA \\
\hline PCB 209 & $0.28 U$ & $0.27 \mathrm{U}$ & $0.27 \mathrm{U}$ & NA & $0.27 \mathrm{U}$ & $0.27 \mathrm{U}$ & $0.27 \mathrm{U}$ & NA \\
\hline \multicolumn{9}{|c|}{ Surrogate Recoveries (\%) } \\
\hline PCB 103 (SIS) & 84 & 82 & 84 & NA & 81 & 82 & 69 & NA \\
\hline PCB 198 (SIS) & 102 & 113 & 112 & NA & 102 & 95 & 82 & NA \\
\hline
\end{tabular}


Table B.6. (contd)

Analytical Replicates

\begin{tabular}{|c|c|c|c|c|c|c|c|c|}
\hline \multirow{5}{*}{$\begin{array}{l}\text { Sediment Treatment } \\
\text { Replicate } \\
\text { Sample Size (L) } \\
\text { Batch }\end{array}$} & \multirow{2}{*}{\multicolumn{3}{|c|}{ Concentration (ng/L) }} & \multirow{5}{*}{$\begin{array}{l}\text { RSD } \\
(\%)\end{array}$} & \multirow{2}{*}{\multicolumn{3}{|c|}{ Concentration (ng/L) }} & \multirow{5}{*}{$\begin{array}{l}\text { RSD } \\
(\%)\end{array}$} \\
\hline & & & & & & & & \\
\hline & $\begin{array}{c}\text { WC- }^{(10)} \\
1\end{array}$ & $\begin{array}{c}\text { WC-8 } \\
2\end{array}$ & $\begin{array}{c}\text { WC- } 8 \\
3\end{array}$ & & $\begin{array}{c}B X-14^{(0)} \\
1\end{array}$ & $\begin{array}{c}B X-14 \\
2\end{array}$ & $\begin{array}{c}\mathrm{BX}-14 \\
3\end{array}$ & \\
\hline & 1.06 & 1.07 & 1.06 & & 1.07 & 1.07 & 1.07 & \\
\hline & 1 & 1 & 1 & & 1 & 1 & 1 & \\
\hline $2,4^{\prime}-\mathrm{DDD}$ & $0.94 \mathrm{U}$ & $0.93 \mathrm{U}$ & $0.94 U$ & NA & $0.93 \mathrm{U}$ & $0.93 \mathrm{U}$ & $0.93 \mathrm{U}$ & NA \\
\hline 2,4'-DDE & $0.23 U$ & $0.23 U$ & $0.23 \mathrm{U}$ & NA & $0.23 \mathrm{U}$ & $0.23 \mathrm{U}$ & $0.23 \mathrm{U}$ & NA \\
\hline 2,4'-DDT & $0.44 \mathrm{U}$ & $0.43 U$ & $0.44 U$ & NA & $0.43 \mathrm{U}$ & $0.43 U$ & $0.43 \mathrm{U}$ & NA \\
\hline 4,4'-DDD & $0.45 \mathrm{U}$ & $0.44 U$ & $0.45 \mathrm{U}$ & NA & $0.44 U$ & $0.44 U$ & 4.71 & NA \\
\hline 4,4'-DDE & 2.98 & 2.45 & 3.49 & 17 & 2.63 & 2.35 & 3.48 & 21 \\
\hline 4,4'-DDT & $0.40 \mathrm{U}$ & $0.40 \mathrm{U}$ & $0.40 \mathrm{U}$ & NA & $0.40 \mathrm{U}$ & $0.40 \mathrm{U}$ & 4.79 & NA \\
\hline$\alpha$-Chlordane & $0.83 \mathrm{U}$ & $0.82 \mathrm{U}$ & $0.83 \mathrm{U}$ & NA & $0.82 U$ & $0.82 \mathrm{U}$ & $0.82 U$ & NA \\
\hline Aldrin & $0.39 \mathrm{U}$ & $0.38 \mathrm{U}$ & $0.39 \mathrm{U}$ & NA & $0.38 \mathrm{U}$ & $0.38 \mathrm{U}$ & $0.38 \mathrm{U}$ & NA \\
\hline Dieldrin & $0.12 U$ & $0.12 U$ & $0.12 U$ & NA & 2.77 & 2.82 & 4.62 & $31^{(1)}$ \\
\hline Endosulfan I & $0.46 U$ & $0.46 \mathrm{U}$ & $0.46 \mathrm{U}$ & NA & $0.46 \mathrm{U}$ & $0.46 U$ & $0.46 U$ & NA \\
\hline Endosulfan II & $0.46 \mathrm{U}$ & $0.46 \mathrm{U}$ & $0.46 \mathrm{U}$ & NA & $0.46 U$ & $0.46 \mathrm{U}$ & $0.46 U$ & NA \\
\hline Endosulfan Sulfate & $0.46 \mathrm{U}$ & $0.46 U$ & $0.46 U$ & NA & $0.46 \mathrm{U}$ & $0.46 U$ & $0.46 \mathrm{U}$ & NA \\
\hline Heptachlor & $0.47 \mathrm{U}$ & $0.46 \mathrm{U}$ & $0.47 \mathrm{U}$ & NA & $0.46 \mathrm{U}$ & $0.46 \mathrm{U}$ & $0.46 \mathrm{U}$ & NA \\
\hline Heptachlor Epoxide & $0.11 \mathrm{U}$ & $0.11 \mathrm{U}$ & $0.11 \mathrm{U}$ & NA & $0.11 U$ & $0.11 U$ & 1.52 & NA \\
\hline Trans Nonachlor & $1.11 \mathrm{U}$ & $1.10 \mathrm{U}$ & $1.11 \mathrm{U}$ & NA & $1.10 \mathrm{U}$ & $1.10 \mathrm{U}$ & $1.10 \mathrm{U}$ & NA \\
\hline РСB 8 & $1.00 \mathrm{U}$ & $0.98 \mathrm{U}$ & $1.00 \mathrm{U}$ & NA & $0.98 U$ & $0.98 \mathrm{U}$ & $0.98 \mathrm{U}$ & NA \\
\hline РCB 18 & $1.05 \mathrm{U}$ & $1.04 \mathrm{U}$ & $1.05 U$ & NA & 1.54 & $1.04 \mathrm{U}$ & $1.04 \mathrm{U}$ & NA \\
\hline РСВ 28 & $0.71 U$ & $0.70 \mathrm{U}$ & $0.71 \mathrm{U}$ & NA & $0.70 \mathrm{U}$ & $0.70 \mathrm{U}$ & $0.70 \mathrm{U}$ & NA \\
\hline РСВ 44 & $0.31 \mathrm{U}$ & $0.30 \mathrm{U}$ & $0.31 \mathrm{U}$ & NA & $0.30 \mathrm{U}$ & $0.30 \mathrm{U}$ & $0.30 \mathrm{U}$ & NA \\
\hline РСВ 49 & $0.53 \mathrm{U}$ & $0.53 \mathrm{U}$ & $0.53 U$ & NA & $0.53 \mathrm{U}$ & $0.53 U$ & $0.53 U$ & NA \\
\hline РСB 52 & $0.35 \mathrm{U}$ & $0.35 \mathrm{U}$ & $0.35 \mathrm{U}$ & NA & $0.35 \mathrm{U}$ & $0.35 \mathrm{U}$ & $0.35 \mathrm{U}$ & NA \\
\hline РСВ 66 & $0.38 \mathrm{U}$ & $0.38 \mathrm{U}$ & $0.38 U$ & NA & $0.38 \mathrm{U}$ & $0.38 \mathrm{U}$ & $0.38 \mathrm{U}$ & NA \\
\hline РСB 87 & $0.35 \mathrm{U}$ & $0.35 \mathrm{U}$ & $0.35 \mathrm{U}$ & NA & $0.35 U$ & $0.35 \mathrm{U}$ & $0.35 \mathrm{U}$ & NA \\
\hline PCB 101 & $0.48 \mathrm{U}$ & $0.48 \mathrm{U}$ & $0.48 \mathrm{U}$ & NA & $0.48 \mathrm{U}$ & $0.48 \mathrm{U}$ & $0.48 \mathrm{U}$ & NA \\
\hline PCB 105 & $0.30 \mathrm{U}$ & $0.29 \mathrm{U}$ & $0.30 \mathrm{U}$ & NA & $0.29 \mathrm{U}$ & $0.29 \mathrm{U}$ & $0.29 \mathrm{U}$ & NA \\
\hline PCB 118 & $0.47 U$ & $0.46 \mathrm{U}$ & $0.47 U$ & NA & $0.46 \mathrm{U}$ & $0.46 U$ & $0.46 \mathrm{U}$ & NA \\
\hline PCB 128 & $0.24 \mathrm{U}$ & $0.24 \mathrm{U}$ & $0.24 U$ & NA & $0.24 \mathrm{U}$ & $0.24 U$ & $0.24 U$ & NA \\
\hline PCB 138 & $0.34 \mathrm{U}$ & $0.34 \mathrm{U}$ & $0.34 U$ & NA & $0.34 U$ & $0.34 \mathrm{U}$ & $0.34 \mathrm{U}$ & NA \\
\hline PCB 153 & $0.39 \mathrm{U}$ & $0.39 \mathrm{U}$ & $0.39 \mathrm{U}$ & NA & 0.44 & 0.41 & 0.44 & 4 \\
\hline PCB 170 & $0.20 \mathrm{U}$ & $0.20 \mathrm{U}$ & $0.20 \mathrm{U}$ & NA & $0.20 \mathrm{U}$ & $0.20 \mathrm{U}$ & $0.20 \mathrm{U}$ & NA \\
\hline PCB 180 & $0.27 \mathrm{U}$ & $0.27 \mathrm{U}$ & $0.27 \mathrm{U}$ & NA & $0.27 \mathrm{U}$ & $0.27 \mathrm{U}$ & $0.27 \mathrm{U}$ & NA \\
\hline PCB 183 & $0.53 U$ & $0.53 U$ & $0.53 U$ & NA & $0.53 \mathrm{U}$ & $0.53 \mathrm{U}$ & $0.53 \mathrm{U}$ & NA \\
\hline PCB 184 & $0.53 \mathrm{U}$ & $0.53 \mathrm{U}$ & $0.53 \mathrm{U}$ & NA & $0.53 \mathrm{U}$ & $0.53 U$ & $0.53 \mathrm{U}$ & NA \\
\hline PCB 187 & $0.39 \mathrm{U}$ & $0.38 \mathrm{U}$ & $0.39 \mathrm{U}$ & NA & $0.38 \mathrm{U}$ & $0.38 \mathrm{U}$ & $0.38 \mathrm{U}$ & NA \\
\hline PCB 195 & $0.27 \mathrm{U}$ & $0.27 \mathrm{U}$ & $0.27 \mathrm{U}$ & NA & $0.27 \mathrm{U}$ & $0.27 \mathrm{U}$ & $0.27 \mathrm{U}$ & NA \\
\hline PCB 206 & $0.39 \mathrm{U}$ & $0.39 \mathrm{U}$ & $0.39 \mathrm{U}$ & NA & $0.39 \mathrm{U}$ & $0.39 \mathrm{U}$ & $0.39 \mathrm{U}$ & NA \\
\hline PCB 209 & $0.27 \mathrm{U}$ & $0.27 \mathrm{U}$ & $0.27 \mathrm{U}$ & NA & $0.27 \mathrm{U}$ & $0.27 U$ & $0.27 \mathrm{U}$ & NA \\
\hline \multicolumn{9}{|c|}{ Surrogate Recoveries $(\%)$} \\
\hline PCB 103 (SIS) & 79 & 75 & 96 & NA & 81 & 82 & 86 & NA \\
\hline PCB 198 (SIS) & 119 & 145 & 149 & NA & 127 & 121 & 126 & NA \\
\hline \multicolumn{9}{|c|}{$\begin{array}{l}\text { (a) Undetected at or above given concentration. } \\
\text { (b) NS Not spiked. } \\
\text { (c) NA Not applicable. } \\
\text { (d) Sample randomly selected for use as a quality control sample in analytical batch. } \\
\text { (e) Matrix interference; value estimated. } \\
\text { (f) Outside quality control criteria }(<30 \%) \text { for replicate analysis. }\end{array}$} \\
\hline
\end{tabular}


Table B.7. Pesticides and Polychlorinated Biphenyls (PCBs) in Elutriate Samples, Bronx River

\begin{tabular}{|c|c|c|c|c|}
\hline \multirow{5}{*}{$\begin{array}{l}\text { Sediment Treatment } \\
\text { Replicate } \\
\text { Sample Size (L) } \\
\text { Batch }\end{array}$} & \multicolumn{4}{|c|}{ Concentration (ng/L) } \\
\hline & Sequim Bay Water & $\mathrm{BX}$ COMP & BX COMP & BX COMP \\
\hline & 1 & 1 & 2 & 3 \\
\hline & 1.00 & 1.05 & 1.05 & 1.05 \\
\hline & 1 & 1 & 1 & 1 \\
\hline $2,4^{\prime}-\mathrm{DDD}^{(a)}$ & $1.00 U^{(b)}$ & $0.95 \mathrm{U}$ & $0.95 \mathrm{U}$ & $0.95 U$ \\
\hline 2,4'-DDE & $0.24 \mathrm{U}$ & $0.23 \mathrm{U}$ & $0.23 \mathrm{U}$ & $0.23 \mathrm{U}$ \\
\hline 2,4'-DDT & $0.46 \mathrm{U}$ & $0.44 \mathrm{U}$ & $0.44 \mathrm{U}$ & $0.44 \mathrm{U}$ \\
\hline 4,4'-DDD & $0.48 \mathrm{U}$ & 9.76 & 7.64 & 7.92 \\
\hline 4,4'-DDE & $0.29 \mathrm{U}$ & 9.55 & 9.55 & 8.54 \\
\hline 4,4'-DDT & $0.43 \mathrm{U}$ & 12.6 & 8.69 & 9.71 \\
\hline$\alpha$-Chlordane & $0.88 \mathrm{U}$ & 4.50 & $0.83 \mathrm{U}$ & $0.83 \mathrm{U}$ \\
\hline Aldrin & $0.41 \mathrm{U}$ & $0.39 \mathrm{U}$ & $0.39 \mathrm{U}$ & $0.39 \mathrm{U}$ \\
\hline Dieldrin & $0.13 \mathrm{U}$ & 5.97 & 5.61 & 4.96 \\
\hline Endosulfan I & $0.49 \mathrm{U}$ & $0.47 \mathrm{U}$ & $0.47 \mathrm{U}$ & $0.47 \mathrm{U}$ \\
\hline Endosulfan II & $0.49 \mathrm{U}$ & $0.470 \mathrm{U}$ & 1.04 & 1.20 \\
\hline Endosulfan Sulfate & $0.49 \mathrm{U}$ & $0.47 \mathrm{U}$ & $0.47 \mathrm{U}$ & 0.66 \\
\hline Heptachlor & $0.50 \mathrm{U}$ & $0.47 \mathrm{U}$ & $0.47 \mathrm{U}$ & 0.88 \\
\hline Heptachlor Epoxide & $0.12 \mathrm{U}$ & $0.11 \mathrm{U}$ & $0.11 \mathrm{U}$ & $0.11 \mathrm{U}$ \\
\hline Trans Nonachlor & $1.18 \mathrm{U}$ & 1.27 & $1.12 \mathrm{U}$ & $1.12 \mathrm{U}$ \\
\hline РСВ 8 & $1.06 \mathrm{U}$ & $1.01 \mathrm{U}$ & $1.01 \mathrm{U}$ & $1.01 \mathrm{U}$ \\
\hline РСB 18 & $1.12 \mathrm{U}$ & 29.3 & 18.2 & 16.9 \\
\hline РСВ 28 & $0.75 \mathrm{U}$ & 11.8 & 6.77 & 8.84 \\
\hline РСB 44 & $0.33 \mathrm{U}$ & $0.31 \mathrm{U}$ & $0.31 \mathrm{U}$ & $0.31 \mathrm{U}$ \\
\hline РСB 49 & $0.57 \mathrm{U}$ & 6.46 & 2.58 & 2.30 \\
\hline РСв 52 & $0.38 \mathrm{U}$ & $0.36 \mathrm{U}$ & $0.36 \mathrm{U}$ & $0.36 \mathrm{U}$ \\
\hline РСB 66 & $0.41 \mathrm{U}$ & $0.39 \mathrm{U}$ & $0.39 \mathrm{U}$ & $0.39 \mathrm{U}$ \\
\hline РСВ 87 & $0.38 \mathrm{U}$ & 1.88 & 0.97 & 1.03 \\
\hline PCB 101 & $0.52 \mathrm{U}$ & 8.43 & 3.14 & 2.54 \\
\hline PCB 105 & $0.32 \mathrm{U}$ & $0.30 \mathrm{U}$ & $0.30 \mathrm{U}$ & $0.30 \mathrm{U}$ \\
\hline PCB 118 & $0.50 U$ & 6.07 & 2.58 & 2.32 \\
\hline PCB 128 & $0.26 \mathrm{U}$ & $0.24 \mathrm{U}$ & $0.24 \mathrm{U}$ & $0.24 \mathrm{U}$ \\
\hline PCB 138 & $0.36 U$ & 8.0 & 3.92 & 3.49 \\
\hline PCB 153 & $0.42 \mathrm{U}$ & 12.5 & 5.33 & 4.74 \\
\hline PCB 170 & $0.21 \mathrm{U}$ & $0.20 \mathrm{U}$ & 1.17 & $0.20 \mathrm{U}$ \\
\hline PCB 180 & $0.29 \mathrm{U}$ & 8.55 & 3.84 & 3.61 \\
\hline РCB 183 & $0.57 \mathrm{U}$ & 1.56 & 0.98 & $0.54 \mathrm{U}$ \\
\hline PCB 184 & $0.57 \mathrm{U}$ & $0.54 \mathrm{U}$ & $0.54 \mathrm{U}$ & $0.54 \mathrm{U}$ \\
\hline PCB 187 & $0.41 \mathrm{U}$ & 7.02 & $0.39 \mathrm{U}$ & $0.39 \mathrm{U}$ \\
\hline PCB 195 & $0.29 \mathrm{U}$ & $0.28 \mathrm{U}$ & $0.28 \mathrm{U}$ & $0.28 \mathrm{U}$ \\
\hline PCB 206 & $0.42 \mathrm{U}$ & $0.39 \mathrm{U}$ & $0.39 \mathrm{U}$ & $0.39 \mathrm{U}$ \\
\hline PCB 209 & $0.29 \mathrm{U}$ & 1.29 & $0.28 \mathrm{U}$ & $0.28 \mathrm{U}$ \\
\hline \multicolumn{5}{|c|}{ Surrogate Recoveries $(\%)$} \\
\hline PCB 103 (SIS) & 78 & 72 & 77 & 71 \\
\hline PCB 198 (SIS) & 76 & 69 & 73 & 69 \\
\hline
\end{tabular}

(a) Target detection limits range from $0.5 \mathrm{ng} / \mathrm{L}$ to $100 \mathrm{ng} / \mathrm{L}$ for all analytes.

(b) $U$ Undetected at or above given concentration. 
Table B.8. Quality Control Data for Pesticide and Polychlorinated Biphenyl (PCB) Analysis of Elutriate Samples

\begin{tabular}{|c|c|c|c|c|c|c|}
\hline \multirow{4}{*}{$\begin{array}{l}\text { Sediment Treatment } \\
\text { Analytical Replicate } \\
\text { Sample Size (L) } \\
\text { Batch }\end{array}$} & \multicolumn{6}{|c|}{ Matrix Spike Results } \\
\hline & \multirow{3}{*}{$\begin{array}{c}\text { Blank } \\
1.00 \\
1\end{array}$} & \multicolumn{4}{|c|}{ Concentration (ng/L) } & \multirow{3}{*}{$\begin{array}{c}\text { Percent } \\
\text { Recovery }\end{array}$} \\
\hline & & \multirow{2}{*}{$\begin{array}{c}\text { Sequim Bay } \\
\text { Water } \\
1.00 \\
1\end{array}$} & \multirow{2}{*}{$\begin{array}{c}\text { Sequim Bay } \\
\text { Water (MS) } \\
1.00 \\
1\end{array}$} & \multicolumn{2}{|c|}{ Concentration } & \\
\hline & & & & Spiked & Recovered & \\
\hline 2,4'-DDD & $1.00 U^{(a)}$ & $1.00 \mathrm{U}$ & $1.00 \mathrm{U}$ & $\mathrm{NS}^{\left(D^{2}\right)}$ & $\mathrm{NA}^{(\mathrm{C})}$ & NS \\
\hline 2,4'-DDE & $0.24 \mathrm{U}$ & $0.24 \mathrm{U}$ & $0.24 \mathrm{U}$ & NS & NA & NA \\
\hline 2,4'-DDT & $0.46 \mathrm{U}$ & $0.46 \mathrm{U}$ & $0.46 \mathrm{U}$ & NS & NA & NS \\
\hline 4,4'-DDD & $0.48 U$ & $0.48 \mathrm{U}$ & 25.4 & 25.0 & 25.4 & 102 \\
\hline 4,4'-DDE & $0.29 \mathrm{U}$ & $0.29 U$ & 23.3 & 25.0 & 23.3 & 93 \\
\hline 4,4'-DDT & $0.43 \mathrm{U}$ & $0.43 \mathrm{U}$ & 27.1 & 25.0 & 27.1 & 108 \\
\hline$\alpha$-Chlordane & $0.88 \mathrm{U}$ & $0.88 \mathrm{U}$ & 20.9 & 25.0 & 20.9 & 84 \\
\hline Aldrin & $0.41 \mathrm{U}$ & $0.41 \mathrm{U}$ & 20.8 & 25.0 & 20.8 & 83 \\
\hline Dieldrin & $0.13 U$ & $0.13 \mathrm{U}$ & 22.6 & 25.0 & 22.6 & 91 \\
\hline Endosulfan 1 & $0.49 U$ & $0.49 U$ & 22.0 & 25.0 & 22.0 & 88 \\
\hline Endosulfan II & $0.49 U$ & $0.49 \mathrm{U}$ & 24.3 & 25.0 & 24.3 & 97 \\
\hline Endosulfan Sulfate & $0.49 \mathrm{U}$ & $0.49 \mathrm{U}$ & 28.3 & 25.0 & 28.3 & 113 \\
\hline Heptachlor & $0.50 \mathrm{U}$ & $0.50 \mathrm{U}$ & 22.1 & 25.0 & 22.1 & 88 \\
\hline Heptachlor Epoxide & $0.12 U$ & $0.12 U$ & 22.5 & 25.0 & 22.5 & 90 \\
\hline Trans Nonachlor & $1.18 \mathrm{U}$ & $1.18 \mathrm{U}$ & $1.18 \mathrm{U}$ & NS & NA & NA \\
\hline PCB 8 & $1.06 \mathrm{U}$ & $1.06 \mathrm{U}$ & $1.06 \mathrm{U}$ & NS & NA & NS \\
\hline PCB 18 & $1.12 \mathrm{U}$ & $1.12 U$ & $1.12 U$ & NS & NA & NS \\
\hline РСВ 28 & $0.75 U$ & $0.75 \mathrm{U}$ & 35.4 & 31.9 & 35.4 & 111 \\
\hline РСB 44 & $0.33 U$ & $0.33 U$ & $0.33 \mathrm{U}$ & NS & NA & NS \\
\hline РСВ 49 & $0.57 \mathrm{U}$ & $0.57 \mathrm{U}$ & $0.57 \mathrm{U}$ & NS & NA & NS \\
\hline РCB 52 & $0.38 \mathrm{U}$ & $0.38 \mathrm{U}$ & 72.7 & 66.5 & 72.7 & 109 \\
\hline РСB 66 & $0.41 U$ & $0.41 \mathrm{U}$ & $0.41 U$ & NS & NA & NS \\
\hline PCB 87 & $0.38 U$ & $0.38 U$ & $0.38 U$ & NS & NA & NS \\
\hline PCB 101 & $0.52 U$ & $0.52 \mathrm{U}$ & 53.4 & 45.1 & 53.4 & 118 \\
\hline PCB 105 & $0.32 \mathrm{U}$ & $0.32 U$ & $0.32 U$ & NS & NA & NS \\
\hline PCB 118 & $0.50 \mathrm{U}$ & $0.50 \mathrm{U}$ & $0.50 \mathrm{U}$ & NS & NA & NS \\
\hline PCB 128 & $0.26 \mathrm{U}$ & $0.26 \mathrm{U}$ & $0.26 \mathrm{U}$ & NS & NA & NS \\
\hline PCB 138 & $0.36 \mathrm{U}$ & $0.36 \mathrm{U}$ & 23.2 & 20.4 & 23.2 & 114 \\
\hline PCB 153 & $0.42 U$ & $0.42 U$ & 31.1 & 26.4 & 31.1 & 118 \\
\hline PCB 170 & $0.21 \mathrm{U}$ & $0.21 \mathrm{U}$ & $0.21 \mathrm{U}$ & NS & NA & NS \\
\hline PCB 180 & $0.29 \mathrm{U}$ & $0.29 \mathrm{U}$ & $0.29 \mathrm{U}$ & NS & NA & NS \\
\hline РCB 183 & $0.57 \mathrm{U}$ & $0.57 \mathrm{U}$ & $0.57 \mathrm{U}$ & NS & NA & NS \\
\hline PCB 184 & $0.57 \mathrm{U}$ & $0.57 \mathrm{U}$ & $0.57 \mathrm{U}$ & NS & NA & NS \\
\hline PCB 187 & $0.41 \mathrm{U}$ & $0.41 \mathrm{U}$ & $0.41 U$ & NS & NA & NS \\
\hline PCB 195 & $0.29 \mathrm{U}$ & $0.29 \mathrm{U}$ & $0.29 \mathrm{U}$ & NS & NA & NS \\
\hline PCB 206 & $0.42 \mathrm{U}$ & $0.42 U$ & $0.42 \mathrm{U}$ & NS & NA & NS \\
\hline PCB 209 & $0.29 \mathrm{U}$ & $0.29 \mathrm{U}$ & $0.29 \mathrm{U}$ & NS & NA & NS \\
\hline \multicolumn{7}{|c|}{ Surrogate Recoveries (\%) } \\
\hline PCB 103 (SIS) & 48 & 78 & 79 & NA & NA & NA \\
\hline PCB 198 (SIS) & 45 & 76 & 77 & NA & NA & NA \\
\hline
\end{tabular}


Table B.8. (contd)

Analytical Replicates

\begin{tabular}{|c|c|c|c|c|c|c|c|c|}
\hline \multirow{4}{*}{$\begin{array}{l}\text { Sediment Treatment } \\
\text { Analytical Replicate } \\
\text { Sample Size (L) } \\
\text { Batch }\end{array}$} & \multirow{2}{*}{\multicolumn{3}{|c|}{$\frac{\text { Concentration (ng/L) }}{\text { SH COMP(a) SH COMP SH COMP }}$}} & \multicolumn{5}{|c|}{ Concentration (ng/L) } \\
\hline & & & & \multirow{3}{*}{$\begin{array}{l}\text { RSD } \\
\text { (\%) }\end{array}$} & \multicolumn{3}{|c|}{ WC COMP(a) WC COMP WC COMP } & \multirow{3}{*}{$\begin{array}{l}\text { RSD } \\
(\%)\end{array}$} \\
\hline & 1.07 & 1.08 & 1.07 & & 1.06 & 1.06 & 1.01 & \\
\hline & 1 & 1 & 1 & & 1 & 1 & 1 & \\
\hline $2,4^{\prime}-\mathrm{DDD}$ & $0.93 \mathrm{U}$ & $0.93 \mathrm{U}$ & $0.93 \mathrm{U}$ & NA & $0.95 \mathrm{U}$ & $0.95 \mathrm{U}$ & $0.99 \mathrm{U}$ & NA \\
\hline 2,4'-DDE & $0.23 \mathrm{U}$ & $0.23 \mathrm{U}$ & $0.23 \mathrm{U}$ & NA & $0.23 \mathrm{U}$ & $0.23 \mathrm{U}$ & $0.24 \mathrm{U}$ & NA \\
\hline 2,4'-DDT & $0.43 \mathrm{U}$ & $0.43 \mathrm{U}$ & $0.43 U$ & NA & $0.44 U$ & $0.44 \mathrm{U}$ & $0.46 U$ & NA \\
\hline 4,4'-DDD & $0.44 \mathrm{U}$ & $0.44 \mathrm{U}$ & $0.44 \mathrm{U}$ & NA & $0.45 \mathrm{U}$ & 3.49 & 3.85 & $72^{(e)}$ \\
\hline 4,4'-DDE & $0.27 \mathrm{U}$ & $0.27 \mathrm{U}$ & $0.27 \mathrm{U}$ & NA & $0.28 \mathrm{U}$ & $0.28 \mathrm{U}$ & $0.29 \mathrm{U}$ & NA \\
\hline 4,4'-DDT & $0.40 \mathrm{U}$ & $0.40 \mathrm{U}$ & $0.40 \mathrm{U}$ & NA & 8.42 & 3.88 & 4.37 & $45^{(e)}$ \\
\hline$\alpha$-Chlordane & $0.82 U$ & $0.82 U$ & $0.82 \mathrm{U}$ & NA & $0.83 \mathrm{U}$ & $0.83 \mathrm{U}$ & $0.87 \mathrm{U}$ & NA \\
\hline Aldrin & $0.38 \mathrm{U}$ & $0.38 \mathrm{U}$ & $0.38 \mathrm{U}$ & NA & $0.39 \mathrm{U}$ & $0.39 \mathrm{U}$ & $0.41 \mathrm{U}$ & NA \\
\hline Dieldrin & $0.12 \mathrm{U}$ & $0.12 U$ & $0.12 U$ & NA & 6.84 & 3.06 & 3.25 & $49^{(e)}$ \\
\hline Endosulfan I & $0.46 \mathrm{U}$ & $0.46 U$ & $0.46 \mathrm{U}$ & NA & $0.47 U$ & $0.47 U$ & $0.49 \mathrm{U}$ & NA \\
\hline Endosulfan II & $0.46 \mathrm{U}$ & $0.46 \mathrm{U}$ & $0.46 \mathrm{U}$ & NA & $0.47 U$ & $0.47 \mathrm{U}$ & $0.49 \mathrm{U}$ & NA \\
\hline Endosulfan Sulfate & $0.46 \mathrm{U}$ & $0.46 U$ & $0.46 \mathrm{U}$ & NA & $0.47 U$ & $0.46 U$ & $0.49 \mathrm{U}$ & NA \\
\hline Heptachlor & $0.46 \mathrm{U}$ & $0.46 U$ & $0.46 \mathrm{U}$ & NA & $0.47 \mathrm{U}$ & $0.47 \mathrm{U}$ & $0.49 \mathrm{U}$ & NA \\
\hline Heptachlor Epoxide & $0.11 \mathrm{U}$ & $0.11 \mathrm{U}$ & $0.11 \mathrm{U}$ & NA & $0.11 \mathrm{U}$ & $0.11 \mathrm{U}$ & $0.12 U$ & NA \\
\hline Trans Nonachlor & $1.10 \mathrm{U}$ & $1.10 \mathrm{U}$ & $1.10 u$ & NA & $1.12 \mathrm{U}$ & $1.12 \mathrm{U}$ & $1.17 \mathrm{U}$ & NA \\
\hline PCB 8 & $0.98 \mathrm{U}$ & $0.98 \mathrm{U}$ & $0.98 U$ & NA & $1.01 \mathrm{U}$ & $1.00 \mathrm{U}$ & $1.05 \mathrm{U}$ & NA \\
\hline PCB 18 & $1.04 \mathrm{U}$ & $1.04 \mathrm{U}$ & $1.04 U$ & NA & $1.06 \mathrm{U}$ & $1.05 \mathrm{U}$ & $1.11 \mathrm{U}$ & NA \\
\hline PCB 28 & $0.70 \mathrm{U}$ & $0.70 \mathrm{U}$ & $0.70 \mathrm{U}$ & NA & $0.71 \mathrm{U}$ & 1.01 & $0.74 U$ & NA \\
\hline PCB 44 & $0.30 \mathrm{U}$ & $0.30 \mathrm{U}$ & $0.30 \mathrm{U}$ & NA & $0.31 \mathrm{U}$ & $0.31 \mathrm{U}$ & $0.32 \mathrm{U}$ & NA \\
\hline РСВ 49 & $0.53 \mathrm{U}$ & $0.53 \mathrm{U}$ & $0.53 U$ & NA & $0.54 \mathrm{U}$ & $0.53 \mathrm{U}$ & $0.56 \mathrm{U}$ & NA \\
\hline РСB 52 & $0.35 U$ & $0.35 \mathrm{U}$ & $0.35 \mathrm{U}$ & NA & $0.36 \mathrm{U}$ & $0.35 \mathrm{U}$ & $0.37 \mathrm{U}$ & NA \\
\hline PCB 66 & $0.38 \mathrm{U}$ & $0.38 \mathrm{U}$ & $0.38 \mathrm{U}$ & NA & $0.39 \mathrm{U}$ & $0.38 \mathrm{U}$ & $0.40 \mathrm{U}$ & NA \\
\hline РCB 87 & $0.35 \mathrm{U}$ & $0.35 \mathrm{U}$ & $0.35 \mathrm{U}$ & NA & $0.36 \mathrm{U}$ & $0.35 \mathrm{U}$ & $0.37 \mathrm{U}$ & NA \\
\hline PCB 101 & $0.48 U$ & $0.48 U$ & $0.48 \mathrm{U}$ & NA & 1.62 & $0.48 U$ & $0.51 \mathrm{U}$ & NA \\
\hline РCB 105 & $0.29 \mathrm{U}$ & $0.29 \mathrm{U}$ & $0.29 \mathrm{U}$ & NA & $0.30 \mathrm{U}$ & $0.30 \mathrm{U}$ & $0.31 \mathrm{U}$ & NA \\
\hline РСВ 118 & $0.46 \mathrm{U}$ & $0.46 \mathrm{U}$ & $0.46 \mathrm{U}$ & NA & 1.84 & $0.47 \mathrm{U}$ & $0.49 \mathrm{U}$ & NA \\
\hline PCB 128 & $0.24 \mathrm{U}$ & $0.24 \mathrm{U}$ & $0.24 \mathrm{U}$ & NA & $0.24 \mathrm{U}$ & $0.24 \mathrm{U}$ & $0.25 \mathrm{U}$ & NA \\
\hline РСВ 138 & $0.34 \mathrm{U}$ & $0.34 \mathrm{U}$ & $0.34 \mathrm{U}$ & NA & 2.00 & $0.34 \mathrm{U}$ & 0.64 & NA \\
\hline PCB 153 & $0.39 \mathrm{U}$ & $0.39 \mathrm{U}$ & $0.39 \mathrm{U}$ & NA & 1.55 & $0.39 \mathrm{U}$ & 0.47 & NA \\
\hline РСВ 170 & $0.20 \mathrm{U}$ & $0.20 \mathrm{U}$ & $0.20 \mathrm{U}$ & NA & $0.20 \mathrm{U}$ & $0.20 \mathrm{U}$ & $0.21 \mathrm{U}$ & NA \\
\hline PCB 180 & $0.27 \mathrm{U}$ & $0.27 \mathrm{U}$ & $0.27 \mathrm{U}$ & NA & $0.28 U$ & $0.27 \mathrm{U}$ & $0.29 \mathrm{U}$ & NA \\
\hline PCB 183 & $0.53 \mathrm{U}$ & $0.53 \mathrm{U}$ & $0.53 \mathrm{U}$ & NA & $0.54 \mathrm{U}$ & $0.53 \mathrm{U}$ & $0.56 \mathrm{U}$ & NA \\
\hline PCB 184 & $0.53 \mathrm{U}$ & $0.53 \mathrm{U}$ & $0.53 U$ & NA & $0.54 \mathrm{U}$ & $0.53 \mathrm{U}$ & $0.56 \mathrm{U}$ & NA \\
\hline PCB 187 & $0.38 \mathrm{U}$ & $0.38 \mathrm{U}$ & $0.38 \mathrm{U}$ & NA & $0.39 \mathrm{U}$ & $0.39 \mathrm{U}$ & $0.41 U$ & NA \\
\hline PCB 195 & $0.27 \mathrm{U}$ & $0.27 \mathrm{U}$ & $0.27 U$ & NA & $0.28 \mathrm{U}$ & $0.27 \mathrm{U}$ & $0.29 \mathrm{U}$ & NA \\
\hline РСВ 206 & $0.39 \mathrm{U}$ & $0.39 \mathrm{U}$ & $0.39 \mathrm{U}$ & NA & $0.39 \mathrm{U}$ & $0.39 \mathrm{U}$ & $0.41 \mathrm{U}$ & NA \\
\hline РСB 209 & $0.27 \mathrm{U}$ & $0.27 \mathrm{U}$ & $0.27 \mathrm{U}$ & NA & $0.28 \mathrm{U}$ & $0.27 \mathrm{U}$ & $0.29 \mathrm{U}$ & NA \\
\hline \multicolumn{9}{|c|}{ Surrogate Recoveries (\%) } \\
\hline PCB 103 (SIS) & 66 & 65 & 66 & NA & 64 & $5^{(f)}$ & $0^{(\mathfrak{f})}$ & NA \\
\hline PCB 198 (SIS) & 66 & 68 & 67 & NA & 60 & $0^{(\mathfrak{l})}$ & $0^{(f)}$ & NA \\
\hline
\end{tabular}


Table B.8. (contd)

Analytical Replicates

\begin{tabular}{|c|c|c|c|c|c|c|c|c|}
\hline \multirow{3}{*}{$\begin{array}{l}\text { Sediment Treatment } \\
\text { Analytical Replicate }\end{array}$} & \multicolumn{3}{|c|}{ Concentration (ng/L) } & \multicolumn{4}{|c|}{ Concentration (ng/L) } & \multirow{5}{*}{$\begin{array}{c}\text { RSD } \\
(\%)\end{array}$} \\
\hline & SR COMP $^{(0)}$ & SR COMP & SR COMP & \multirow{4}{*}{$\begin{array}{c}\text { RSD } \\
(\%)\end{array}$} & \multicolumn{3}{|c|}{ BX COMP ${ }^{(0)}$ BX COMP BX COMP } & \\
\hline & & & & & & & & \\
\hline Sample Size (L) & 1.06 & 1.06 & 1.05 & & 1.05 & 1.05 & 1.05 & \\
\hline Batch & 1 & 1 & 1 & & 1 & 1 & 1 & \\
\hline $2,4^{\prime}-\mathrm{DDD}$ & $0.95 \mathrm{U}$ & $0.95 \mathrm{U}$ & $0.95 \mathrm{U}$ & NA & $0.95 \mathrm{U}$ & $0.95 \mathrm{U}$ & $0.95 \mathrm{U}$ & NA \\
\hline 2,4'-DDE & $0.23 \mathrm{U}$ & $0.23 \mathrm{U}$ & $0.23 \mathrm{U}$ & NA & $0.23 \mathrm{U}$ & $0.23 \mathrm{U}$ & $0.23 \mathrm{U}$ & NA \\
\hline 2,4'-DDT & $0.44 \mathrm{U}$ & $0.44 \mathrm{U}$ & $0.44 \mathrm{U}$ & NA & $0.44 \mathrm{U}$ & $0.44 \mathrm{U}$ & $0.44 \mathrm{U}$ & NA \\
\hline 4,4-DDD & $0.45 \mathrm{U}$ & $0.45 \mathrm{U}$ & $0.45 \mathrm{U}$ & NA & 9.76 & 7.64 & 7.92 & 14 \\
\hline 4,4'-DDE & $0.28 \mathrm{U}$ & $0.28 \mathrm{U}$ & $0.28 \mathrm{U}$ & NA & 9.55 & 9.55 & 8.54 & 6 \\
\hline 4,4'-DDT & $0.41 \mathrm{U}$ & $0.41 \mathrm{U}$ & $0.41 \mathrm{U}$ & NA & 12.6 & 8.69 & 9.71 & 19 \\
\hline$\alpha$-Chlordane & $0.83 \mathrm{U}$ & $0.83 \mathrm{U}$ & $0.83 \mathrm{U}$ & NA & 4.50 & $0.83 \mathrm{U}$ & $0.83 \mathrm{U}$ & NA \\
\hline Aldrin & $0.39 \mathrm{U}$ & $0.39 U$ & $0.39 \mathrm{U}$ & NA & $0.39 U$ & $0.39 \mathrm{U}$ & $0.39 \mathrm{U}$ & NA \\
\hline Dieldrin & $0.13 \mathrm{U}$ & $0.13 \mathrm{U}$ & $0.13 \mathrm{U}$ & NA & 5.97 & 5.61 & 4.96 & 9 \\
\hline Endosulfan I & $0.47 \mathrm{U}$ & $0.47 \mathrm{U}$ & $0.47 \mathrm{U}$ & NA & $0.47 \mathrm{U}$ & $0.47 \mathrm{U}$ & $0.47 U$ & NA \\
\hline Endosulfan II & $0.47 \mathrm{U}$ & $0.47 U$ & $0.47 \mathrm{U}$ & NA & $0.47 U$ & 1.04 & 1.20 & NA \\
\hline Endosulfan Sulfate & $0.47 \mathrm{U}$ & $0.47 \mathrm{U}$ & $0.47 \mathrm{U}$ & NA & $0.47 \mathrm{U}$ & $0.47 \mathrm{U}$ & 0.66 & NA \\
\hline Heptachlor & $0.47 \mathrm{U}$ & $0.47 \mathrm{U}$ & $0.47 \mathrm{U}$ & NA & $0.47 U$ & $0.47 \mathrm{U}$ & 0.88 & NA \\
\hline Heptachlor Epoxide & $0.11 \mathrm{U}$ & $0.11 \mathrm{U}$ & $0.11 \mathrm{U}$ & NA & $0.11 \mathrm{U}$ & $0.11 \mathrm{U}$ & $0.11 \mathrm{U}$ & NA \\
\hline Trans Nonachlor & $1.12 U$ & $1.12 \mathrm{U}$ & $1.12 \mathrm{U}$ & NA & 1.27 & $1.12 \mathrm{U}$ & $1.12 \mathrm{U}$ & NA \\
\hline PCB 8 & $1.01 \mathrm{U}$ & $1.01 \mathrm{U}$ & $1.01 \mathrm{U}$ & NA & $1.01 \mathrm{U}$ & $1.01 \mathrm{U}$ & $1.01 \mathrm{U}$ & NA \\
\hline PCB 18 & $1.06 \mathrm{U}$ & $1.06 \mathrm{U}$ & $1.06 U$ & NA & 29.3 & 18.2 & 16.9 & $32^{(e)}$ \\
\hline PCB 28 & $0.71 \mathrm{U}$ & $0.71 \mathrm{U}$ & $0.71 \mathrm{U}$ & NA & 11.8 & 6.77 & 8.84 & 27 \\
\hline PCB 44 & $0.31 \mathrm{U}$ & $0.31 \mathrm{U}$ & $0.31 \mathrm{U}$ & NA & $0.31 \mathrm{U}$ & $0.31 \mathrm{U}$ & $0.31 U$ & NA \\
\hline РCB 49 & $0.54 \mathrm{U}$ & $0.54 U$ & $0.54 \mathrm{U}$ & NA & 6.46 & 2.58 & 2.30 & $62^{(\mathrm{e})}$ \\
\hline РCB 52 & $0.36 \mathrm{U}$ & $0.36 U$ & $0.36 \mathrm{U}$ & NA & $0.36 \mathrm{U}$ & $0.36 \mathrm{U}$ & $0.36 U$ & NA \\
\hline PCB 66 & $0.39 \mathrm{U}$ & $0.39 \mathrm{U}$ & $0.39 \mathrm{U}$ & NA & $0.39 U$ & $0.39 \mathrm{U}$ & $0.39 \mathrm{U}$ & $N A$ \\
\hline PCB 87 & $0.36 \mathrm{U}$ & $0.36 \mathrm{U}$ & $0.36 \mathrm{U}$ & NA & 1.88 & 0.97 & 1.03 & $39^{(e)}$ \\
\hline PCB 101 & $0.49 \mathrm{U}$ & $0.49 \mathrm{U}$ & $0.49 \mathrm{U}$ & NA & 8.43 & 3.14 & 2.54 & $69^{\text {(e) }}$ \\
\hline PCB 105 & $0.30 \mathrm{U}$ & $0.30 \mathrm{U}$ & $0.30 \mathrm{U}$ & NA & $0.30 \mathrm{U}$ & $0.30 \mathrm{U}$ & $0.30 \mathrm{U}$ & NA \\
\hline PCB 118 & $0.47 \mathrm{U}$ & $0.47 \cup$ & $0.47 \mathrm{U}$ & NA & 6.07 & 2.58 & 2.32 & $57^{(\mathrm{e})}$ \\
\hline PCB 128 & $0.24 \mathrm{U}$ & $0.24 \mathrm{U}$ & $0.24 \mathrm{U}$ & NA & $0.24 U$ & $0.24 \mathrm{U}$ & $0.24 \mathrm{U}$ & NA \\
\hline PCB 138 & $0.35 \mathrm{U}$ & $0.35 \mathrm{U}$ & $0.35 \mathrm{U}$ & NA & 8.00 & 3.92 & 3.49 & $48^{(e)}$ \\
\hline PCB 153 & $0.40 \mathrm{U}$ & $0.40 \mathrm{U}$ & $0.40 \mathrm{U}$ & NA & 12.5 & 5.33 & 4.74 & $57^{(e)}$ \\
\hline PCB 170 & $0.20 \mathrm{U}$ & $0.20 \mathrm{U}$ & $0.20 \mathrm{U}$ & NA & $0.20 \mathrm{U}$ & 1.17 & $0.20 \mathrm{U}$ & NA \\
\hline PCB 180 & $0.28 \mathrm{U}$ & $0.28 \mathrm{U}$ & $0.28 \mathrm{U}$ & NA & 8.55 & 3.84 & 3.61 & $52^{(\mathrm{e})}$ \\
\hline PCB 183 & $0.54 \mathrm{U}$ & $0.54 \mathrm{U}$ & $0.54 \mathrm{U}$ & NA & 1.56 & 0.98 & $0.54 \mathrm{U}$ & NA \\
\hline РCB 184 & $0.54 \mathrm{U}$ & $0.54 \mathrm{U}$ & $0.54 \mathrm{U}$ & NA & $0.54 \mathrm{U}$ & $0.54 \mathrm{U}$ & $0.54 \mathrm{U}$ & NA \\
\hline РСB 187 & $0.39 \mathrm{U}$ & $0.39 \mathrm{U}$ & $0.39 \mathrm{U}$ & NA & 7.02 & $0.39 \mathrm{U}$ & $0.39 \mathrm{U}$ & NA \\
\hline PCB 195 & $0.28 \mathrm{U}$ & $0.28 U$ & $0.28 \mathrm{U}$ & NA & $0.28 U$ & $0.28 U$ & $0.28 \mathrm{U}$ & NA \\
\hline PCB 206 & $0.39 \mathrm{U}$ & $0.39 \mathrm{U}$ & $0.39 \mathrm{U}$ & NA & $0.39 U$ & $0.39 \mathrm{U}$ & $0.39 u$ & NA \\
\hline PCB 209 & $0.28 \mathrm{U}$ & $0.28 \mathrm{U}$ & $0.28 \mathrm{U}$ & NA & 1.29 & $0.28 U$ & $0.28 \mathrm{U}$ & NA \\
\hline \multicolumn{9}{|c|}{ Surrogate Recoveries (\%) } \\
\hline PCB 103 (SIS) & $0^{(f)}$ & $0^{(f)}$ & 65 & NA & 72 & 77 & 71 & NA \\
\hline PCB 198 (SIS) & $0^{(f)}$ & $0^{(f)}$ & 67 & NA & 69 & 73 & 69 & NA \\
\hline \multicolumn{9}{|c|}{$\begin{array}{l}\text { (a) U Undetected at or above given concentration. } \\
\text { (b) NS Not spiked. } \\
\text { (c) NA Not applicable. } \\
\text { (d) Sample randomly selected for use as a quality control sample in analytical batch. } \\
\text { (e) Outside quality control criteria }(\leq 30 \%) \text { for replicate analysis. }\end{array}$} \\
\hline
\end{tabular}




\section{Appendix C}

\section{Benthic Acute Toxicity Test Data, Bronx River Project}



Table C.1 Results of 10-Day, Static-Renewal, Benthic Acute Toxicity Test with $A$. abdita, Bronx River

\begin{tabular}{|c|c|c|c|c|c|c|}
\hline Sediment Treatment & Replicate & Live (a) & $\begin{array}{l}\text { Dead or } \\
\text { Missing }\end{array}$ & $\begin{array}{c}\text { Proportion } \\
\text { Surviving }\end{array}$ & $\begin{array}{c}\text { Mean } \\
\text { Proportion } \\
\text { Surviving }\end{array}$ & $\begin{array}{l}\text { Standard } \\
\text { Deviation }\end{array}$ \\
\hline BX COMP & 1 & 14 & 6 & 0.70 & & \\
\hline BX COMP & 2 & 15 & 5 & 0.75 & & \\
\hline BX COMP & 3 & 11 & 9 & 0.55 & & \\
\hline BX COMP & 4 & 11 & 9 & 0.55 & & \\
\hline BX COMP & 5 & 14 & 6 & 0.70 & 0.65 & 0.09 \\
\hline MDRS $^{(b)}$ & 1 & 17 & 3 & 0.85 & & \\
\hline MDRS & 2 & 20 & 0 & 1.00 & & \\
\hline MDRS & 3 & 20 & 0 & 1.00 & & \\
\hline MDRS & 4 & 19 & 1 & 0.95 & & \\
\hline MDRS & 5 & 19 & 1 & 0.95 & 0.95 & 0.06 \\
\hline Ampelisca Control & 1 & 19 & 1 & 0.95 & & \\
\hline Ampelisca Control & 2 & 20 & 0 & 1.00 & & \\
\hline Ampelisca Control & 3 & 20 & 0 & 1.00 & & \\
\hline Ampelisca Control & 4 & 19 & 1 & 0.95 & & \\
\hline Ampelisca Control & 5 & 20 & 0 & 1.00 & 0.98 & 0.03 \\
\hline
\end{tabular}

(a) Survival based on initial exposure of 20 organisms per replicate.

(b) MDRS Mud Dump Reference Site. 
Table C.2. Water Quality Data for 10-Day, Static-Renewal, Benthic Acute Toxicity Test with $A$. abdita, Bronx River

\begin{tabular}{|c|c|c|c|c|c|c|c|c|c|c|}
\hline \multirow[b]{2}{*}{ Sediment Treatment } & \multicolumn{2}{|c|}{$\begin{array}{c}\text { Temperature } \\
\left({ }^{\circ} \mathrm{C}\right)\end{array}$} & \multicolumn{2}{|c|}{$\mathrm{pH}$} & \multicolumn{2}{|c|}{$\begin{array}{c}\text { Dissolved } \\
\text { Oxygen } \\
\text { (mg/L) }\end{array}$} & \multicolumn{2}{|c|}{$\begin{array}{c}\text { Salinity } \\
(\%)\end{array}$} & \multicolumn{2}{|c|}{$\begin{array}{c}\text { Total } \\
\text { Ammonia }^{(a)} \\
(\mathrm{mg} / \mathrm{L})\end{array}$} \\
\hline & Min & $\operatorname{Max}$ & Min & Max & Min & Max & Min & Max & Min & $\operatorname{Max}$ \\
\hline Acceptable Range: & 18.0 & 22.0 & 7.30 & 8.30 & 4.6 & $N A^{(\mathbf{b})}$ & 28.0 & 32.0 & NA & 30.0 \\
\hline BX COMP & 19.8 & 20.2 & 8.10 & $8.42^{(c)}$ & 6.2 & 7.2 & 30.0 & 30.5 & 0.034 & 0.339 \\
\hline MDRS $^{(d)}$ & 19.9 & 20.2 & 7.93 & 8.12 & 6.7 & 7.1 & 30.0 & 30.5 & 0.033 & 0.136 \\
\hline Ampelisca Control & 19.6 & 20.1 & 8.11 & $8.36^{(c)}$ & 6.1 & 7.0 & 30.0 & 30.5 & 0.011 & 0.086 \\
\hline $\begin{array}{l}\text { (a) Total ammonia n } \\
\text { (b) NA Not applicab } \\
\text { (c) Data point out of } \\
\text { (d) MDRS Mud Dun }\end{array}$ & Refe. & in ove & Ig wat & & & & & & & \\
\hline
\end{tabular}


Table C.3. Results of 96-Hour, Cadmium Reference Toxicant Test with $A$. abdita

\begin{tabular}{|c|c|c|c|c|c|c|}
\hline $\begin{array}{c}\text { Cadmium } \\
\text { Concentration }(\mathrm{mg} / \mathrm{L})\end{array}$ & Replicate & Live $^{(a)}$ & $\begin{array}{l}\text { Dead or } \\
\text { Missing }\end{array}$ & $\begin{array}{l}\text { Proportion } \\
\text { Surviving }\end{array}$ & $\begin{array}{c}\text { Mean } \\
\text { Proportion } \\
\text { Surviving }\end{array}$ & $\begin{array}{l}\text { Standard } \\
\text { Deviation }\end{array}$ \\
\hline 0.00 & 1 & 20 & 0 & 1.00 & & \\
\hline 0.00 & 2 & 19 & 1 & 0.95 & & \\
\hline 0.00 & 3 & 19 & 1 & 0.95 & 0.97 & 0.03 \\
\hline 0.19 & 1 & 17 & 3 & 0.85 & & \\
\hline 0.19 & 2 & 15 & 5 & 0.75 & & \\
\hline 0.19 & 3 & 17 & 3 & 0.85 & 0.82 & 0.06 \\
\hline 0.38 & 1 & 14 & 6 & 0.70 & & \\
\hline 0.38 & 2 & 13 & 7 & 0.65 & & \\
\hline 0.38 & 3 & 14 & 6 & 0.70 & 0.68 & 0.03 \\
\hline 0.75 & 1 & 10 & 10 & 0.50 & & \\
\hline 0.75 & 2 & 11 & 9 & 0.55 & & \\
\hline 0.75 & 3 & 8 & 12 & 0.40 & 0.48 & 0.08 \\
\hline 1.50 & 1 & 2 & 18 & 0.10 & & \\
\hline 1.50 & 2 & 2 & 18 & 0.10 & & \\
\hline 1.50 & 3 & 0 & 20 & 0.00 & 0.07 & 0.06 \\
\hline
\end{tabular}

(a) Survival based on initial exposure of 20 organisms per replicate. 
Table C.4. Water Quality Data for 96-Hour, Cadmium Reference Toxicant Test with A. abdita

\begin{tabular}{|c|c|c|c|c|c|c|c|c|}
\hline \multirow{2}{*}{$\begin{array}{c}\text { Cadmium } \\
\text { Concentration } \\
(\mathrm{mg} / \mathrm{L})\end{array}$} & \multicolumn{2}{|c|}{$\begin{array}{c}\text { Temperature } \\
\left({ }^{\circ} \mathrm{C}\right) \\
\end{array}$} & \multicolumn{2}{|c|}{$\mathrm{pH}$} & \multicolumn{2}{|c|}{$\begin{array}{c}\text { Dissolved } \\
\text { Oxygen } \\
\text { (mg/L) }\end{array}$} & \multicolumn{2}{|c|}{$\begin{array}{c}\text { Salinity } \\
(\% \circ)\end{array}$} \\
\hline & $\operatorname{Min}$ & $\operatorname{Max}$ & Min & Max & Min & Max & Min & $\operatorname{Max}$ \\
\hline Acceptable Range: & 18.0 & 22.0 & 7.30 & 8.30 & 4.6 & $N A^{(a)}$ & 28.0 & 32.0 \\
\hline 0.00 & 19.9 & 20.2 & 8.03 & 8.17 & 6.8 & 7.2 & 30.0 & 30.5 \\
\hline 0.19 & 19.9 & 20.1 & 7.94 & 8.18 & 6.9 & 7.2 & 30.0 & 30.5 \\
\hline 0.38 & 19.7 & 20.3 & 7.98 & 8.14 & 6.9 & 7.2 & 30.0 & 30.5 \\
\hline 0.75 & 19.9 & 20.2 & 7.91 & 8.14 & 6.9 & 7.3 & 30.0 & 31.0 \\
\hline 1.50 & 19.9 & 20.2 & 7.96 & 8.11 & 6.9 & 7.3 & 30.0 & 30.5 \\
\hline
\end{tabular}

(a) NA Not applicable. 
Table C.5. Results of 10-day, Static-Renewal, Benthic Acute Toxicity Test with M. bahia, Bronx River

\begin{tabular}{|c|c|c|c|c|c|c|}
\hline Sediment Treatment & Replicate & Live (a) & $\begin{array}{l}\text { Dead or } \\
\text { Missing }\end{array}$ & $\begin{array}{c}\text { Proportion } \\
\text { Survival } \\
\end{array}$ & $\begin{array}{c}\text { Mean } \\
\text { Proportion } \\
\text { Survival } \\
\end{array}$ & $\begin{array}{l}\text { Standard } \\
\text { Deviation }\end{array}$ \\
\hline BX COMP & 1 & 19 & 1 & 0.95 & & \\
\hline BX COMP & 2 & 19 & 1 & 0.95 & & \\
\hline BX COMP & 3 & 19 & 1 & 0.95 & & \\
\hline BX COMP & 4 & 20 & 0 & 1.00 & & \\
\hline BX COMP & 5 & 19 & 1 & 0.95 & 0.96 & 0.02 \\
\hline MDRS $^{(b)}$ & 1 & 17 & 3 & 0.85 & & \\
\hline MDRS & 2 & 20 & 0 & 1.00 & & \\
\hline MDRS & 3 & 19 & 1 & 0.95 & & \\
\hline MDRS & 4 & 17 & 3 & 0.85 & & \\
\hline MDRS & 5 & 18 & 2 & 0.90 & 0.91 & 0.07 \\
\hline Sequim Bay Control & 1 & 18 & 2 & 0.90 & & \\
\hline Sequim Bay Control & 2 & 18 & 2 & 0.90 & & \\
\hline Sequim Bay Control & 3 & 17 & 3 & 0.85 & & \\
\hline Sequim Bay Control & 4 & 20 & 0 & 1.00 & & \\
\hline Sequim Bay Control & 5 & 19 & 1 & 0.95 & 0.92 & 0.06 \\
\hline
\end{tabular}

(a) Survival based on initial exposure of 20 organisms per replicate.

(b) MDRS Mud Dump Reference Site. 
Table C.6. Water Quality Data for 10-Day, Static-Renewal, Benthic Acute Toxicity Test with M. bahia, Bronx River

\begin{tabular}{|c|c|c|c|c|c|c|c|c|c|c|}
\hline \multirow[b]{2}{*}{ Sediment Treatment } & \multicolumn{2}{|c|}{$\begin{array}{c}\text { Temperature } \\
\left({ }^{\circ} \mathrm{C}\right) \\
\end{array}$} & \multicolumn{2}{|c|}{$\mathrm{pH}$} & \multicolumn{2}{|c|}{$\begin{array}{c}\text { Dissolved } \\
\text { Oxygen } \\
\text { (mg/L) }\end{array}$} & \multicolumn{2}{|c|}{$\begin{array}{c}\text { Salinity } \\
(\% o)\end{array}$} & \multicolumn{2}{|c|}{$\begin{array}{c}\text { Total } \\
\text { Ammonia }^{(a)} \\
(\mathrm{mg} / \mathrm{L})\end{array}$} \\
\hline & Min & Max & Min & Max & Min & Max & Min & Max & Min & Max \\
\hline Acceptable Range: & 18.0 & 22.0 & 7.30 & 8.30 & 3.0 & $N A^{(a)}$ & 28.0 & 32.0 & NA & 15.0 \\
\hline $\mathrm{BX}$ COMP & 19.3 & 20.1 & 8.03 & $8.51^{\text {(c) }}$ & 6.0 & 7.0 & 30.0 & 31.0 & 0.079 & 11.5 \\
\hline MDRS $^{(d)}$ & 19.4 & 20.3 & 7.84 & $8.41^{(c)}$ & 6.1 & 7.1 & 30.0 & 31.0 & 0.265 & 2.49 \\
\hline Mysid Control & 19.3 & 20.1 & 7.96 & $8.63^{(c)}$ & 6.3 & 7.0 & 30.0 & 31.0 & 0.094 & 1.51 \\
\hline $\begin{array}{l}\text { (a) Total ammonia } \\
\text { (b) NA Not applicak } \\
\text { (c) Data point out of } \\
\text { (d) MDRS Mud Dur }\end{array}$ & ired & ovel & wate & & & & & & & \\
\hline
\end{tabular}


Table C.7. Results of 96-Hour, Copper Reference Toxicant Test with M. bahia

Mean

Copper

Dead or Proportion Proportion Standard

Concentration $(\mu \mathrm{g} / \mathrm{L})$ Replicate Live

Missing Surviving Surviving Deviation

$\begin{array}{ccccccc}0 & 1 & 10 & 0 & 1.00 & & \\ 0 & 2 & 10 & 0 & 1.00 & & \\ 0 & 3 & 10 & 0 & 1.00 & 1.00 & 0.00 \\ 150 & 1 & 10 & 0 & 1.00 & & \\ 150 & 2 & 10 & 0 & 1.00 & & \\ 150 & 3 & 10 & 0 & 1.00 & 1.00 & 0.00 \\ & & & & & & \\ 200 & 1 & 8 & 2 & 0.80 & & \\ 200 & 2 & 8 & 2 & 0.80 & & 0.06 \\ 200 & 3 & 9 & 1 & 0.90 & 0.83 & \\ 300 & 1 & 3 & 7 & 0.30 & & \\ 300 & 2 & 4 & 6 & 0.40 & & \\ 300 & 3 & 4 & 6 & 0.40 & 0.37 & 0.06 \\ 400 & 1 & 0 & 10 & 0.00 & & \\ 400 & 2 & 0 & 10 & 0.00 & & \\ 400 & 3 & 0 & 10 & 0.00 & 0.00 & 0.00\end{array}$

(a) Survival based on initial exposure of 10 organisms per replicate 
Table C.8 Water Quality Data for 96-hour, Copper Reference Toxicant Test with $M$. bahia

\begin{tabular}{|c|c|c|c|c|c|c|c|c|}
\hline \multirow{2}{*}{$\begin{array}{c}\text { Copper } \\
\text { Concentration }(\mu \mathrm{g} / \mathrm{L}) \\
\end{array}$} & \multicolumn{2}{|c|}{$\begin{array}{c}\text { Temperature } \\
\left({ }^{\circ} \mathrm{C}\right)\end{array}$} & \multicolumn{2}{|c|}{$\mathrm{pH}$} & \multicolumn{2}{|c|}{$\begin{array}{c}\text { Dissolved } \\
\text { Oxygen }(\mathrm{mg} / \mathrm{L})\end{array}$} & \multicolumn{2}{|c|}{ Salinity (\%o) } \\
\hline & Min & Max & Min & Max & Min & Max & Min & Max \\
\hline Acceptable Range: & 18.0 & 22.0 & 7.30 & 8.30 & 3.0 & $N^{(a)}$ & 28.0 & 32.0 \\
\hline 0 & 20.0 & 20.2 & 8.00 & 8.15 & 6.5 & 7.1 & 30.5 & 31.5 \\
\hline 150 & 20.1 & 20.2 & 8.06 & 8.14 & 6.6 & 7.2 & 30.5 & 32.0 \\
\hline 200 & 20.1 & 20.3 & 8.04 & 8.13 & 6.7 & 7.2 & 30.5 & 31.5 \\
\hline 300 & 20.0 & 20.3 & 8.03 & 8.17 & 6.7 & 7.2 & 30.5 & 32.0 \\
\hline 400 & 19.9 & 20.2 & 7.97 & 8.18 & 6.7 & 7.2 & 30.5 & 32.0 \\
\hline
\end{tabular}

(a) NA Not applicable. 
Appendix D

\section{Water-Column Toxicity Test Data, Bronx River Project}



Table D.1. Results of 96-Hour, Water-Column Toxicity Test with M. beryllina, Bronx River

\begin{tabular}{|c|c|c|c|c|c|c|c|}
\hline $\begin{array}{l}\text { Sediment } \\
\text { Treatment } \\
\end{array}$ & $\begin{array}{c}\text { Concentration } \\
(\% \text { SPP }) \\
\end{array}$ & Replicate & $\operatorname{Live}^{(a)}$ & $\begin{array}{l}\text { Dead or } \\
\text { Missing }\end{array}$ & $\begin{array}{c}\text { Proportion } \\
\text { Surviving } \\
\end{array}$ & $\begin{array}{c}\text { Mean } \\
\text { Proportion } \\
\text { Surviving } \\
\end{array}$ & $\begin{array}{l}\text { Standard } \\
\text { Deviation }\end{array}$ \\
\hline$B X$ & 0 & 1 & 8 & 2 & 0.80 & & \\
\hline$B X$ & 0 & 2 & 9 & 1 & 0.90 & & \\
\hline$B X$ & 0 & 3 & 9 & 1 & 0.90 & & \\
\hline$B X$ & 0 & 4 & 10 & 0 & 1.00 & & \\
\hline$B X$ & 0 & 5 & 9 & 1 & 0.90 & 0.90 & 0.07 \\
\hline$B X$ & 10 & 1 & 8 & 2 & 0.80 & & \\
\hline $\mathrm{BX}$ & 10 & 2 & 9 & 1 & 0.90 & & \\
\hline$B X$ & 10 & 3 & 8 & 2 & 0.80 & & \\
\hline$B X$ & 10 & 4 & 8 & 2 & 0.80 & & \\
\hline$B X$ & 10 & 5 & 9 & 1 & 0.90 & 0.84 & 0.05 \\
\hline$B X$ & 50 & 1 & 0 & 10 & 0.00 & & \\
\hline$B X$ & 50 & 2 & 0 & 10 & 0.00 & & \\
\hline $\mathrm{BX}$ & 50 & 3 & 0 & 10 & 0.00 & & \\
\hline$B X$ & 50 & 4 & 0 & 10 & 0.00 & & \\
\hline$B X$ & 50 & 5 & 1 & 9 & 0.10 & 0.02 & 0.04 \\
\hline$B X$ & 100 & 1 & 0 & 10 & 0.00 & & \\
\hline$B X$ & 100 & 2 & 0 & 10 & 0.00 & & \\
\hline$B X$ & 100 & 3 & 0 & 10 & 0.00 & & \\
\hline$B X$ & 100 & 4 & 0 & 10 & 0.00 & & \\
\hline$B X$ & 100 & 5 & 0 & 10 & 0.00 & 0.00 & 0.00 \\
\hline Brine Control & & 1 & 7 & 3 & 0.70 & & \\
\hline Brine Control & & 2 & 10 & 0 & 1.00 & & \\
\hline Brine Control & & 3 & 9 & 1 & 0.90 & & \\
\hline Brine Control & & 4 & 10 & 0 & 1.00 & & \\
\hline Brine Control & & 5 & 9 & 1 & 0.90 & 0.90 & 0.12 \\
\hline
\end{tabular}

(a) Survival based on initial exposure of 10 organisms per replicate.

D.1 
Table D.2. Water Quality Data for 96-Hour, Water-Column Toxicity Test with M. beryllina, Bronx River

\begin{tabular}{|c|c|c|c|c|c|c|c|c|c|}
\hline \multirow{2}{*}{$\begin{array}{l}\text { Sediment } \\
\text { Treatment }\end{array}$} & \multirow{2}{*}{$\begin{array}{c}\text { Concentration } \\
(\% \text { SPP })\end{array}$} & \multicolumn{2}{|c|}{$\begin{array}{c}\text { Temperature } \\
\left({ }^{\circ} \mathrm{C}\right)\end{array}$} & \multicolumn{2}{|c|}{$\mathrm{pH}$} & \multicolumn{2}{|c|}{$\begin{array}{c}\text { Dissolved } \\
\text { Oxygen } \\
\text { (mg/L) }\end{array}$} & \multicolumn{2}{|c|}{$\begin{array}{c}\text { Salinity } \\
(\% \circ)\end{array}$} \\
\hline & & Min & $\operatorname{Max}$ & Min & Max & Min & Max & Min & Max \\
\hline \multicolumn{2}{|c|}{ Acceptable Range: } & 18.0 & 22.0 & 7.30 & 8.30 & 3.0 & $N A^{(a)}$ & 28.0 & 32.0 \\
\hline$B X$ & 0 & 19.0 & 21.3 & 8.04 & 8.12 & 6.6 & 7.8 & 30.0 & 30.5 \\
\hline $\mathrm{BX}$ & 10 & 18.9 & 21.2 & 8.03 & $8.31^{(b)}$ & 5.9 & 7.7 & 30.0 & 30.5 \\
\hline $\mathrm{BX}$ & 50 & 19.0 & 21.4 & 7.93 & $8.36^{(b)}$ & 6.3 & 7.2 & 29.5 & 30.0 \\
\hline $\mathrm{BX}$ & 100 & 19.1 & 21.4 & 7.86 & $8.41^{(b)}$ & 4.6 & 7.0 & 29.5 & 30.0 \\
\hline \multicolumn{2}{|c|}{ Brine Control } & 18.7 & 21.2 & 7.99 & 8.26 & 6.2 & 7.2 & 29.0 & 30.0 \\
\hline
\end{tabular}
(a) NA Not applicable.
(b) Data point out of range. 
Table D.3. Results of 96-Hour, Copper Reference Toxicant Test with M. beryllina

\begin{tabular}{ccccccc}
$\begin{array}{c}\text { Copper } \\
\text { Concentration }(\mu \mathrm{g} / \mathrm{L})\end{array}$ & Replicate & Live ${ }^{(\text {a) }}$ & $\begin{array}{c}\text { Dead or } \\
\text { Missing }\end{array}$ & $\begin{array}{c}\text { Mean } \\
\text { Proportion } \\
\text { Surviving }\end{array}$ & $\begin{array}{c}\text { Proportion } \\
\text { Surviving }\end{array}$ & $\begin{array}{c}\text { Standard } \\
\text { Deviation }\end{array}$ \\
\hline 0 & 1 & 10 & 0 & 1.00 & & \\
0 & 2 & 7 & 3 & 0.70 & & \\
0 & 3 & 10 & 0 & 1.00 & 0.90 & 0.17 \\
16 & 1 & 9 & 1 & 0.90 & & \\
16 & 2 & 5 & 5 & 0.50 & & \\
16 & 3 & 8 & 2 & 0.80 & 0.73 & 0.21 \\
64 & 1 & 10 & 0 & 1.00 & & \\
64 & 2 & 7 & 3 & 0.70 & & \\
64 & 3 & 7 & 3 & 0.70 & 0.80 & 0.17 \\
160 & 1 & 4 & 6 & 0.40 & & \\
160 & 2 & 4 & 6 & 0.40 & & \\
160 & 3 & 7 & 3 & 0.70 & 0.50 & 0.17 \\
400 & 1 & 0 & 10 & 0.00 & & \\
400 & 2 & 0 & 10 & 0.00 & & \\
400 & 3 & 0 & 10 & 0.00 & 0.00 & 0.00
\end{tabular}

(a) Survival based on initial exposure of 10 organisms per replicate. 
Table D.4. Water Quality Data for 96-Hour Copper Reference Toxicant Test with $M$. beryllina

\begin{tabular}{|c|c|c|c|c|c|c|c|c|}
\hline \multirow{2}{*}{$\begin{array}{c}\text { Copper } \\
\text { Concentration } \\
(\mu g / L)\end{array}$} & \multicolumn{2}{|c|}{$\begin{array}{c}\text { Temperature } \\
\left({ }^{\circ} \mathrm{C}\right)\end{array}$} & \multicolumn{2}{|c|}{$\mathrm{pH}$} & \multicolumn{2}{|c|}{$\begin{array}{c}\text { Dissolved } \\
\text { Oxygen } \\
\text { (mg/L) }\end{array}$} & \multicolumn{2}{|c|}{$\begin{array}{c}\text { Salinity } \\
(\%)\end{array}$} \\
\hline & Min & $\operatorname{Max}$ & Min & $\operatorname{Max}$ & Min & Max & Min & Max \\
\hline Acceptable Range: & 18.0 & 22.0 & 7.30 & 8.30 & 3.0 & $N A^{(a)}$ & 28.0 & 32.0 \\
\hline 0 & 18.9 & 21.2 & 8.06 & 8.17 & 6.2 & 7.5 & 30.0 & 31.0 \\
\hline 16 & 18.8 & 21.4 & 8.06 & 8.17 & 6.4 & 7.4 & 30.5 & 31.5 \\
\hline 64 & 18.8 & 21.5 & 7.98 & 8.15 & 6.3 & 7.5 & 30.0 & 31.0 \\
\hline 160 & 18.8 & 21.5 & 8.02 & 8.12 & 6.4 & 7.4 & 30.0 & 31.0 \\
\hline 400 & 19.0 & 21.4 & 7.94 & 8.05 & 6.4 & 7.5 & 30.5 & 31.0 \\
\hline
\end{tabular}

(a) NA Not applicable. 
Table D.5. Results of 96-Hour, Water-Column Toxicity Test with M. bahia, Bronx River

\begin{tabular}{|c|c|c|c|c|c|c|c|}
\hline $\begin{array}{l}\text { Sediment } \\
\text { Treatment }\end{array}$ & $\begin{array}{c}\text { Concentration } \\
(\% \text { SPP })\end{array}$ & Replicate & Live $^{(a)}$ & $\begin{array}{l}\text { Dead or } \\
\text { Missing }\end{array}$ & $\begin{array}{r}\text { Proportion } \\
\text { Surviving } \\
\end{array}$ & $\begin{array}{c}\text { Mean } \\
\text { Proportion } \\
\text { Surviving } \\
\end{array}$ & $\begin{array}{l}\text { Standard } \\
\text { Deviation }\end{array}$ \\
\hline$B X$ & 0 & 1 & 10 & 0 & 1.00 & & \\
\hline$B X$ & 0 & 2 & 10 & 0 & 1.00 & & \\
\hline$B X$ & 0 & 3 & 10 & 0 & 1.00 & & \\
\hline$B X$ & 0 & 4 & 10 & 0 & 1.00 & & \\
\hline$B X$ & 0 & 5 & 10 & 0 & 1.00 & 1.00 & 0.00 \\
\hline$B X$ & 10 & 1 & 9 & 1. & 0.90 & & \\
\hline$B X$ & 10 & 2 & 9 & 1 & 0.90 & & \\
\hline $\mathrm{BX}$ & 10 & 3 & 9 & 1 & 0.90 & & \\
\hline$B X$ & 10 & 4 & 10 & 0 & 1.00 & & \\
\hline$B X$ & 10 & 5 & 10 & 0 & 1.00 & 0.94 & 0.05 \\
\hline$B X$ & 50 & 1 & 9 & 1 & 0.90 & & \\
\hline$B X$ & 50 & 2 & 10 & 0 & 1.00 & & \\
\hline$B X$ & 50 & 3 & 10 & 0 & 1.00 & & \\
\hline $\mathrm{BX}$ & 50 & 4 & 9 & 1 & 0.90 & & \\
\hline$B X$ & 50 & 5 & 10 & 0 & 1.00 & 0.96 & 0.05 \\
\hline$B X$ & 100 & 1 & 2 & 8 & 0.20 & & \\
\hline$B X$ & 100 & 2 & 0 & 10 & 0.00 & & \\
\hline$B X$ & 100 & 3 & 0 & 10 & 0.00 & & \\
\hline$B X$ & 100 & 4 & 0 & 10 & 0.00 & & \\
\hline$B X$ & 100 & 5 & 2 & 8 & 0.20 & 0.08 & 0.11 \\
\hline Brine Control & & 1 & 10 & 0 & 1.00 & & \\
\hline Brine Control & & 2 & 10 & 0 & 1.00 & & \\
\hline Brine Control & & 3 & 10 & 0 & 1.00 & & \\
\hline Brine Control & & 4 & 10 & 0 & 1.00 & & \\
\hline Brine Control & & 5 & 9 & 1 & 0.90 & 0.98 & 0.04 \\
\hline
\end{tabular}

(a) Survival based on initial exposure of 10 replicates 
Table D.6. Water Quality Data for 96-Hour, Water-Column Toxicity Test with M. bahia, Bronx River

\begin{tabular}{|c|c|c|c|c|c|c|c|c|c|}
\hline \multirow{2}{*}{$\begin{array}{l}\text { Sediment } \\
\text { Treatment }\end{array}$} & \multirow{2}{*}{$\begin{array}{c}\text { Concentration } \\
(\% \text { SPP })\end{array}$} & \multicolumn{2}{|c|}{$\begin{array}{c}\text { Temperature } \\
\left({ }^{\circ} \mathrm{C}\right) \\
\end{array}$} & \multicolumn{2}{|c|}{$\mathrm{pH}$} & \multicolumn{2}{|c|}{$\begin{array}{c}\text { Dissolved } \\
\text { Oxygen } \\
(\mathrm{mg} / \mathrm{L})\end{array}$} & \multicolumn{2}{|c|}{$\begin{array}{c}\text { Salinity } \\
(\% \circ)\end{array}$} \\
\hline & & Min & Max & Min & Max & Min & Max & Min & Max \\
\hline \multicolumn{2}{|c|}{ Acceptable Range: } & 18.0 & 22.0 & 7.30 & 8.30 & 3.0 & $N A^{(a)}$ & 28.0 & 32.0 \\
\hline $\mathrm{BX}$ COMP & 0 & 19.7 & 20.7 & 7.89 & 8.08 & 6.1 & 7.7 & 30.5 & 31.0 \\
\hline BX COMP & 10 & 19.7 & 20.6 & 8.01 & 8.27 & 6.1 & 7.6 & 30.0 & 31.0 \\
\hline BX COMP & 50 & 19.7 & 20.7 & 7.93 & 8.27 & 5.3 & 6.8 & 30.0 & 30.5 \\
\hline BX COMP & 100 & 19.7 & 20.7 & 7.90 & $8.52^{(b)}$ & 4.8 & 7.0 & 29.5 & 30.0 \\
\hline Brine Contr & & 19.5 & 20.0 & 7.98 & 8.27 & 6.0 & 7.1 & 29.0 & 30.5 \\
\hline
\end{tabular}
(a) NA Not applicable.
(b) Data point out of range. 
Table D.7. Results of 96-Hour Copper Reference Toxicant Test with M. bahia for Water-Column Toxicity Tests

\begin{tabular}{ccccccc}
$\begin{array}{c}\text { Copper } \\
\text { Concentration }(\mu \mathrm{g} / \mathrm{L})\end{array}$ & Replicate & Live ${ }^{(\mathrm{a})}$ & $\begin{array}{c}\text { Dead or } \\
\text { Missing }\end{array}$ & $\begin{array}{c}\text { Mean } \\
\text { Proportion Proportion Standard } \\
\text { Surviving }\end{array}$ & $\begin{array}{c}\text { Surviving } \\
\text { Deviation }\end{array}$ \\
\hline 0 & 1 & 10 & 0 & 1.00 & & \\
0 & 2 & 10 & 0 & 1.00 & & \\
0 & 3 & 10 & 0 & 1.00 & 1.00 & 0.00 \\
150 & 1 & 10 & 0 & 1.00 & & \\
150 & 2 & 10 & 0 & 1.00 & & \\
150 & 3 & 8 & 2 & 0.80 & 0.93 & 0.12 \\
200 & 1 & 7 & 3 & 0.70 & & \\
200 & 2 & 8 & 2 & 0.80 & & \\
200 & 3 & 8 & 2 & 0.80 & 0.77 & 0.06 \\
300 & 1 & 5 & 5 & 0.50 & & \\
300 & 2 & 6 & 4 & 0.60 & & \\
300 & 3 & 4 & 6 & 0.40 & 0.50 & 0.10 \\
400 & 1 & 2 & 8 & 0.20 & & \\
400 & 2 & 2 & 8 & 0.20 & & \\
400 & 3 & 0 & 10 & 0.00 & 0.13 & 0.12
\end{tabular}

(a) Survival based on initial exposure of 10 organisms per replicate 
Table D.8. Water Quality Data for 96-Hour Copper Reference Toxicant Test with M. bahia

\begin{tabular}{|c|c|c|c|c|c|c|c|c|}
\hline \multirow{2}{*}{$\begin{array}{c}\text { Copper } \\
\text { Concentration } \\
(\mu g / L)\end{array}$} & \multicolumn{2}{|c|}{$\begin{array}{c}\text { Temperature } \\
\left({ }^{\circ} \mathrm{C}\right)\end{array}$} & \multicolumn{2}{|c|}{$\mathrm{pH}$} & \multicolumn{2}{|c|}{$\begin{array}{c}\text { Dissolved } \\
\text { Oxygen } \\
\text { (mg/L) }\end{array}$} & \multicolumn{2}{|c|}{$\begin{array}{c}\text { Salinity } \\
(\% \circ)\end{array}$} \\
\hline & Min & $\operatorname{Max}$ & Min & Max & Min & Max & Min & Max \\
\hline Acceptable Range: & 18.0 & 22.0 & 7.30 & 8.30 & 3.0 & $N A^{(a)}$ & 28.0 & 32.0 \\
\hline 0 & 19.6 & 20.2 & 7.91 & 8.18 & 5.9 & 7.8 & 30.5 & 31.5 \\
\hline 150 & 19.6 & 20.2 & 7.97 & 8.11 & 6.3 & 7.8 & 30.5 & 31.5 \\
\hline 200 & 19.8 & 20.3 & 7.89 & 8.10 & 6.4 & 7.4 & 30.5 & 31.5 \\
\hline 300 & 19.7 & 20.2 & 8.01 & 8.12 & 6.6 & 7.4 & 30.0 & 31.5 \\
\hline 400 & 19.7 & 20.2 & 8.03 & 8.12 & 6.8 & 7.5 & 30.0 & 31.5 \\
\hline
\end{tabular}

(a) NA Not applicable. 
Table D.9. Results of 72-Hour, Water-Column Toxicity Test with M. galloprovincialis, Bronx River

\begin{tabular}{|c|c|c|c|c|c|c|c|c|c|c|c|c|}
\hline $\begin{array}{l}\text { Sediment } \\
\text { Treatment }\end{array}$ & $\begin{array}{c}\text { Conc. } \\
\text { (\% SPP) }\end{array}$ & Replicate & $\begin{array}{c}\text { Mean } \\
\text { Stocking } \\
\text { Density } \\
\end{array}$ & $\begin{array}{l}\text { Number } \\
\text { Normal } \\
\end{array}$ & $\begin{array}{l}\text { Number } \\
\text { Abnormal }\end{array}$ & $\begin{array}{l}\text { Numbe } \\
1 \text { Other }\end{array}$ & $\begin{array}{l}\text { Number } \\
\text { Surviving }\end{array}$ & $\begin{array}{l}\text { Proportion } \\
\text { Normal }^{(a)}\end{array}$ & $\begin{array}{c}\text { Mean } \\
\text { Proportion } \\
\text { Normal }\end{array}$ & $\begin{array}{l}\text { Proportion } \\
\text { Surviving }\end{array}$ & $\begin{array}{c}\text { Mean } \\
\text { Proportion } \\
\text { Surviving }\end{array}$ & $\begin{array}{l}\text { Standard } \\
\text { Deviation }^{(c)}\end{array}$ \\
\hline BX COMP & 0 & 1 & 233 & 152 & 25 & 0 & 177 & 0.65 & & 0.76 & & \\
\hline BX COMP & 0 & 2 & 233 & 104 & 18 & 0 & 122 & 0.45 & & 0.52 & & \\
\hline BX COMP & 0 & 3 & 233 & 211 & 15 & 2 & 228 & 0.91 & & 0.98 & & \\
\hline $\mathrm{BX}$ COMP & 0 & 4 & 233 & 171 & 28 & 6 & 205 & 0.73 & & 0.88 & & \\
\hline $\mathrm{BX}$ COMP & 0 & 5 & 233 & 200 & 48 & 1 & 249 & 0.86 & 0.72 & $1.00^{\text {(d) }}$ & 0.83 & 0.20 \\
\hline$B \times C O M P$ & 10 & 1 & 233 & 185 & 38 & 0 & 223 & 0.79 & & 0.96 & & \\
\hline BX COMP & 10 & 2 & 233 & 167 & 45 & 0 & 212 & 0.72 & & 0.91 & & \\
\hline $\mathrm{BX}$ COMP & 10 & 3 & 233 & 222 & 18 & 4 & 244 & 0.95 & & $1.00^{(d)}$ & & \\
\hline$B X$ COMP & 10 & 4 & 233 & 138 & 38 & 0 & 176 & 0.59 & & 0.76 & & \\
\hline BX COMP & 10 & 5 & 233 & 174 & 29 & 2 & 205 & 0.75 & 0.76 & 0.88 & 0.90 & 0.09 \\
\hline$B X$ COMP & 50 & 1 & 233 & 2 & 186 & 0 & 188 & 0.01 & & 0.81 & & \\
\hline $\mathrm{BX}$ COMP & 50 & 2 & 233 & 2 & 196 & 0 & 198 & 0.01 & & 0.85 & & \\
\hline$B \times C O M P$ & 50 & 3 & 233 & 1 & 152 & 0 & 153 & 0.00 & & 0.66 & & \\
\hline$B X$ COMP & 50 & 4 & 233 & 2 & 106 & 41 & 149 & 0.01 & & 0.64 & & \\
\hline BX COMP & 50 & 5 & 233 & 8 & 217 & 1 & 226 & 0.03 & 0.01 & 0.97 & 0.79 & 0.14 \\
\hline$B X$ COMP & 100 & 1 & 233 & 4 & 134 & 3 & 141 & 0.02 & & 0.61 & & \\
\hline BX COMP & 100 & 2 & 233 & 2 & 67 & 0 & 69 & 0.01 & & 0.30 & & \\
\hline $\mathrm{BX}$ COMP & 100 & 3 & 233 & 1 & 121 & 0 & 122 & 0.00 & & 0.52 & & \\
\hline$B X$ COMP & 100 & 4 & 233 & 4 & 114 & 0 & 118 & 0.02 & & 0.51 & & \\
\hline $\mathrm{BX}$ COMP & 100 & 5 & 233 & 0 & 124 & 9 & 133 & 0.00 & 0.01 & 0.57 & 0.50 & 0.12 \\
\hline \multicolumn{2}{|c|}{18.5 ppt Brine Control } & 1 & 241 & 239 & 18 & 2 & 259 & 0.99 & & $1.00^{(d)}$ & & \\
\hline \multirow{2}{*}{\multicolumn{2}{|c|}{$\begin{array}{l}18.5 \text { ppt Brine Control } \\
18.5 \text { ppt Brine Control }\end{array}$}} & 2 & 241 & 281 & 26 & 6 & 313 & $1.00^{(d)}$ & & $1.00^{\text {(d) }}$ & & \\
\hline & & 3 & 241 & 228 & 6 & 1 & 235 & 0.95 & & 0.98 & & \\
\hline \multicolumn{2}{|c|}{18.5 ppt Brine Control } & 4 & 241 & 236 & 0 & 3 & 239 & 0.98 & & 0.99 & & \\
\hline \multicolumn{2}{|c|}{ 18.5 ppt Brine Control } & 5 & 241 & 211 & 3 & 31 & 245 & 0.88 & 0.96 & $1.00^{(d)}$ & 0.99 & 0.01 \\
\hline \multicolumn{13}{|c|}{$\begin{array}{l}\text { (a) Proportion normal = number normal / mean stocking density. } \\
\text { (b) Proportion surviving = number surviving / mean stocking density. } \\
\text { (c) Standard deviation is based on proportion surviving. }\end{array}$} \\
\hline
\end{tabular}


Table D.10. Water Quality Data for 72-Hour, Water-Column Toxicity Test with M. galloprovincialis, Bronx River

\begin{tabular}{|c|c|c|c|c|c|c|c|c|c|}
\hline \multirow{2}{*}{$\begin{array}{l}\text { Sediment } \\
\text { Treatment } \\
\end{array}$} & \multirow{2}{*}{$\begin{array}{c}\text { Concentration } \\
\text { (\% SPP) }\end{array}$} & \multicolumn{2}{|c|}{$\begin{array}{c}\text { Temperature } \\
\left({ }^{\circ} \mathrm{C}\right) \\
\end{array}$} & \multicolumn{2}{|c|}{$\mathrm{pH}$} & \multicolumn{2}{|c|}{$\begin{array}{c}\text { Dissolved } \\
\text { Oxygen } \\
\text { (mg/L) } \\
\end{array}$} & \multicolumn{2}{|c|}{$\begin{array}{c}\text { Salinity } \\
(\% 0)\end{array}$} \\
\hline & & Min & Max & Min & Max & Min & Max & Min & $\operatorname{Max}$ \\
\hline Acceptable Range: & & 14.0 & 18.0 & 7.30 & 8.30 & 4.9 & $N A^{(a)}$ & 28.0 & 32.0 \\
\hline BX COMP & 0 & 16.1 & 16.6 & 8.05 & 8.15 & 7.6 & 8.0 & 30.0 & 30.5 \\
\hline BX COMP & 10 & 16.2 & 16.7 & 7.99 & 8.22 & 7.5 & 7.9 & 30.0 & 30.5 \\
\hline BX COMP & 50 & 16.2 & 16.6 & 7.93 & $8.42^{\text {(b) }}$ & 6.4 & 8.0 & 30.0 & 30.5 \\
\hline BX COMP & 100 & 16.1 & 16.5 & 7.92 & $8.55^{(b)}$ & 5.6 & 8.1 & 29.5 & 30.0 \\
\hline $18.5 \mathrm{ppt}$ Brine Contro & & 16.1 & 16.8 & 7.91 & 8.27 & 6.1 & 8.0 & 30.0 & 30.0 \\
\hline
\end{tabular}


Table D.11. Results of 72-Hour, Copper Reference Toxicant Test with M. galloprovincialis

\begin{tabular}{|c|c|c|c|c|c|c|c|c|c|c|c|}
\hline $\begin{array}{c}\text { Copper } \\
\text { Concentration } \\
(\mu g / L) \\
\end{array}$ & Replicate & $\begin{array}{l}\text { Mean } \\
\text { Stocking } \\
\text { Density } \\
\end{array}$ & $\begin{array}{l}\text { Number } \\
\text { Normal }\end{array}$ & $\begin{array}{c}\text { Number } \\
\text { Abnormal }\end{array}$ & $\begin{array}{l}\text { Number } \\
\text { Other }\end{array}$ & $\begin{array}{l}\text { Number } \\
\text { Surviving }\end{array}$ & $\begin{array}{l}\text { Proportion } \\
\text { Normal }^{(a)}\end{array}$ & $\begin{array}{c}\text { Mean } \\
\text { Proportion } \\
\text { Normal } \\
\end{array}$ & $\begin{array}{l}\text { Proportion } \\
\text { Surviving }^{(b)}\end{array}$ & $\begin{array}{c}\text { Mean } \\
\text { Proportion } \\
\text { Surviving } \\
\end{array}$ & $\begin{array}{c}\text { Standard } \\
\text { Deviation }^{(c)}\end{array}$ \\
\hline 0 & 1 & 258 & 194 & 38 & 0 & 232 & 0.75 & & 0.90 & & \\
\hline 0 & 2 & 258 & 225 & 27 & 0 & 252 & 0.87 & & 0.98 & & \\
\hline 0 & 3 & 258 & 182 & 49 & 3 & 234 & 0.71 & 0.78 & 0.91 & 0.93 & 0.04 \\
\hline 4 & 1 & 258 & 221 & 37 & 2 & 260 & 0.86 & & $1.00^{(d)}$ & & \\
\hline 4 & 2 & 258 & 228 & 31 & 4 & 263 & 0.88 & & $1.00^{(d)}$ & & \\
\hline 4 & 3 & 258 & 220 & 43 & 2 & 265 & 0.85 & 0.86 & $1.00^{(d)}$ & 1.00 & 0.00 \\
\hline 8 & 1 & 258 & 219 & 41 & 1 & 261 & 0.85 & & $1.00^{(\mathrm{d})}$ & & \\
\hline 8 & 2 & 258 & 170 & 49 & 0 & 219 & 0.66 & & 0.85 & & \\
\hline 8 & 3 & 258 & 206 & 43 & 2 & 251 & 0.80 & 0.77 & 0.97 & 0.94 & 0.08 \\
\hline 16 & 1 & 258 & 21 & 212 & 1 & 234 & 0.08 & & 0.91 & & \\
\hline 16 & 2 & 258 & 71 & 209 & 0 & 280 & 0.28 & & $1.00^{(\mathrm{d})}$ & & \\
\hline 16 & 3 & 258 & 5 & 196 & 8 & 209 & 0.02 & 0.13 & 0.81 & 0.91 & 0.10 \\
\hline 32 & 1 & 258 & 4 & 33 & 21 & 58 & 0.02 & & 0.22 & & \\
\hline 32 & 2 & 258 & 2 & 14 & 41 & 57 & 0.01 & & 0.22 & & \\
\hline 32 & 3 & 258 & 0 & 10 & 78 & 88 & 0.00 & 0.01 & 0.34 & 0.26 & 0.07 \\
\hline $\begin{array}{l}\text { (a) Proportior } \\
\text { (b) Proportior } \\
\text { (c) Standard } \\
\text { (d) When nun }\end{array}$ & $\begin{array}{l}\text { n normal = } \\
\text { n surviving } \\
\text { deviation is } \\
\text { mber norm } \\
\text { n surviving }\end{array}$ & $\begin{array}{l}\text { number no } \\
=\text { number } \\
\text { based on } \\
\text { or numb } \\
\text { of } 1.00 \text { wa }\end{array}$ & $\begin{array}{l}\text { rmal / me } \\
\text { surviving / } \\
\text { proportio } \\
\text { r survivin }\end{array}$ & $\begin{array}{l}\text { an stocking } \\
\text { mean stock } \\
\text { surviving. } \\
\text { g exceeded }\end{array}$ & $\begin{array}{l}\text { density. } \\
\text { king densi }\end{array}$ & stocking & ensity, a p & ortion no & nal and/or & & \\
\hline
\end{tabular}


Table D.12 Water Quality Data for 72-Hour, Copper Reference Toxicant Test with M. galloprovincialis

\begin{tabular}{|c|c|c|c|c|c|c|c|c|}
\hline \multirow{2}{*}{$\begin{array}{c}\text { Copper } \\
\text { Concentration } \\
(\mu g / L) \\
\end{array}$} & \multicolumn{2}{|c|}{$\begin{array}{c}\text { Temperature } \\
\left({ }^{\circ} \mathrm{C}\right) \\
\end{array}$} & \multicolumn{2}{|c|}{$\mathrm{pH}$} & \multicolumn{2}{|c|}{$\begin{array}{c}\text { Dissolved } \\
\text { Oxygen } \\
\text { (mg/L) }\end{array}$} & \multicolumn{2}{|c|}{$\begin{array}{c}\text { Salinity } \\
(\% \circ)\end{array}$} \\
\hline & Min & Max & Min & $\operatorname{Max}$ & Min & $\operatorname{Max}$ & Min & Max \\
\hline Acceptable Range: & 14.0 & 18.0 & 7.30 & 8.30 & 4.9 & $N A^{(a)}$ & 28.0 & 32.0 \\
\hline 0 & 16.3 & 16.8 & 7.91 & 8.10 & 7.4 & 7.9 & 30.0 & 31.0 \\
\hline 4 & 16.3 & 16.7 & 7.92 & 8.09 & 7.5 & 7.8 & 30.0 & 31.0 \\
\hline 8 & 16.4 & 16.7 & 7.92 & 8.11 & 7.4 & 7.7 & 30.0 & 31.0 \\
\hline 16 & 16.3 & 16.6 & 7.91 & 8.10 & 7.5 & 7.8 & 30.0 & 30.5 \\
\hline 32 & 16.4 & 16.8 & 7.89 & 8.10 & 7.4 & 7.7 & 30.0 & 31.0 \\
\hline
\end{tabular}

(a) NA Not applicable. 


\section{Appendix E}

\section{Bioaccumulation Test Data, Bronx River Project}



Table E.1. Results of 28-Day Bioaccumulation Test with M. nasuta, Bronx River

\begin{tabular}{lcccccc}
$\begin{array}{l}\text { Sediment } \\
\text { Treatment }\end{array}$ & Replicate & Live ${ }^{(\text {a) }}$ & $\begin{array}{c}\text { Dead or } \\
\text { Missing }\end{array}$ & $\begin{array}{c}\text { Proportion } \\
\text { Surviving }\end{array}$ & $\begin{array}{c}\text { Mean } \\
\text { Proportion } \\
\text { Surviving }\end{array}$ & $\begin{array}{c}\text { Standard } \\
\text { Deviation }\end{array}$ \\
\hline BX COMP & 1 & 24 & 1 & 0.96 & & \\
BX COMP & 2 & 24 & 1 & 0.96 & & \\
BX COMP & 3 & 24 & 1 & 0.96 & & \\
BX COMP & 4 & 24 & 1 & 0.96 & 0.97 & 0.02 \\
BX COMP & 5 & 25 & 0 & 1.00 & & \\
& & & & & & \\
MDRS ${ }^{(b)}$ & 1 & 23 & 2 & 0.92 & & \\
MDRS & 2 & 24 & 1 & 0.96 & & \\
MDRS & 3 & 24 & 1 & 0.96 & & \\
MDRS & 4 & 23 & 2 & 0.92 & & \\
MDRS & 5 & 25 & 0 & 1.00 & 0.95 & \\
& & & & & & \\
Macoma Control & 1 & 23 & 2 & 0.92 & & \\
Macoma Control & 2 & 23 & 2 & 0.92 & & \\
Macoma Control & 3 & 23 & 2 & 0.92 & & \\
Macoma Control & 4 & 24 & 1 & 0.96 & & \\
Macoma Control & 5 & 20 & 5 & 0.80 & 0.90 &
\end{tabular}

(a) Survival based on initial exposure of 25 organisms per replicate.

(b) MDRS Mud Dump Reference Site.

E.1 
Table E.2. Water Quality Summary for 28-Day Bioaccumulation Test with $M$. nasuta, Bronx River

\begin{tabular}{|c|c|c|c|c|c|c|c|c|}
\hline \multirow{2}{*}{$\begin{array}{l}\text { Sediment } \\
\text { Treatment }\end{array}$} & \multicolumn{2}{|c|}{$\begin{array}{c}\text { Temperature } \\
\left({ }^{\circ} \mathrm{C}\right)\end{array}$} & \multicolumn{2}{|c|}{$\mathrm{pH}$} & \multicolumn{2}{|c|}{$\begin{array}{c}\text { Dissolved } \\
\text { Oxygen } \\
\text { (mg/L) }\end{array}$} & \multicolumn{2}{|c|}{$\begin{array}{c}\text { Salinity } \\
(\% \circ)\end{array}$} \\
\hline & Min & $\operatorname{Max}$ & Min & $\operatorname{Max}$ & Min & $\operatorname{Max}$ & Min & Max \\
\hline Acceptable Range: & 13.0 & 17.0 & 7.30 & 8.30 & 5.0 & $N A^{(a)}$ & 28.0 & 32.0 \\
\hline BX COMP & 15.4 & 16.5 & 7.87 & 8.12 & 6.9 & 7.8 & 30.0 & 31.0 \\
\hline $\mathrm{MDRS}^{(\mathfrak{b}\}}$ & 15.3 & 16.6 & 7.88 & 8.11 & 7.1 & 7.9 & 30.0 & 31.0 \\
\hline Macoma Control & 15.4 & 16.6 & 7.90 & 8.10 & 7.2 & 7.8 & 30.0 & 31.0 \\
\hline
\end{tabular}


Table E.3. Results of 96-Hour, Copper Reference Toxicant Test with $M$. nasuta

\begin{tabular}{cccc}
$\begin{array}{c}\text { Copper } \\
\text { Concentration }(\mu \mathrm{g} / \mathrm{L})\end{array}$ & Live $\mathrm{L}^{(\mathrm{a})}$ & $\begin{array}{c}\text { Dead or } \\
\text { Missing }\end{array}$ & $\begin{array}{c}\text { Proportion } \\
\text { Surviving }\end{array}$ \\
\hline 0 & 10 & 0 & 1.00 \\
312 & 9 & 1 & 0.90 \\
625 & 6 & 4 & 0.60 \\
1250 & 3 & 7 & 0.30 \\
2500 & 0 & 10 & 0.00 \\
5000 & 1 & 9 & 0.10 \\
10000 & 0 & 10 & 0.00
\end{tabular}

(a) Survival based on initial exposure of 10 organisms per replicate 
Table E.4. Water Quality Summary for 96-Hour M. nasuta Copper Reference Toxicant Test

\begin{tabular}{|c|c|c|c|c|c|c|c|c|}
\hline \multirow{2}{*}{$\begin{array}{c}\text { Copper } \\
\text { Concentration } \\
(\mu \mathrm{g} / \mathrm{L})\end{array}$} & \multicolumn{2}{|c|}{$\begin{array}{c}\text { Temperature } \\
\left({ }^{\circ} \mathrm{C}\right) \\
\end{array}$} & \multicolumn{2}{|c|}{$\mathrm{pH}$} & \multicolumn{2}{|c|}{$\begin{array}{c}\text { Dissolved } \\
\text { Oxygen } \\
\text { (mg/L) }\end{array}$} & \multicolumn{2}{|c|}{$\begin{array}{c}\text { Salinity } \\
(\% \circ)\end{array}$} \\
\hline & $\operatorname{Min}$ & $\operatorname{Max}$ & Min & Max & Min & Max & Min & Max \\
\hline Acceptable Range: & 13.0 & 17.0 & 7.30 & 8.30 & 5.0 & $N A^{(a)}$ & 28.0 & 32.0 \\
\hline 0 & 15.5 & 16.1 & 8.03 & 8.10 & 7.6 & 7.8 & 30.5 & 31.5 \\
\hline 312 & 15.5 & 16.1 & 7.57 & 8.05 & 5.4 & 7.9 & 30.5 & 31.5 \\
\hline 625 & 15.5 & 16.1 & 7.87 & 8.07 & 6.7 & 7.9 & 30.5 & 31.5 \\
\hline 1250 & 15.6 & 16.1 & 7.58 & 8.05 & $4.3^{\text {(b) }}$ & 8.0 & 30.5 & 31.0 \\
\hline 2500 & 15.7 & 16.2 & 7.30 & 7.96 & $1.2^{\text {(b) }}$ & 8.0 & 30.5 & 31.5 \\
\hline 5000 & 15.6 & 16.2 & 7.31 & 7.82 & $1.4^{(b)}$ & 7.9 & 30.5 & 31.5 \\
\hline 10000 & 15.7 & 16.2 & 7.57 & 7.65 & 5.9 & 8.0 & 30.5 & 31.0 \\
\hline
\end{tabular}

(a) NA Not applicable.

(b) Data point out of range. 
Table E.5. Results of 28-Day Bioaccumulation Test with N.virens, Bronx River

\begin{tabular}{|c|c|c|c|c|c|c|}
\hline $\begin{array}{l}\text { Sediment } \\
\text { Treatment }\end{array}$ & Replicate & Live $^{\text {(a) }}$ & $\begin{array}{l}\text { Dead or } \\
\text { Missing }\end{array}$ & $\begin{array}{c}\text { Proportion } \\
\text { Surviving }\end{array}$ & $\begin{array}{c}\text { Mean } \\
\text { Proportion } \\
\text { Surviving } \\
\end{array}$ & $\begin{array}{l}\text { Standard } \\
\text { Deviation }\end{array}$ \\
\hline BX COMP & 1 & 11 & 9 & 0.55 & & \\
\hline BX COMP & 2 & 13 & 7 & 0.65 & & \\
\hline BX COMP & 3 & 18 & 2 & 0.90 & & \\
\hline BX COMP & 4 & 14 & 6 & 0.70 & & \\
\hline BX COMP & 5 & 19 & 1 & 0.95 & 0.75 & 0.17 \\
\hline MDRS $^{(b)}$ & 1 & 17 & 3 & 0.85 & & \\
\hline MDRS & 2 & 18 & 2 & 0.90 & & \\
\hline MDRS & 3 & 19 & 1 & 0.95 & & \\
\hline MDRS & 4 & 20 & 0 & 1.00 & & \\
\hline MDRS & 5 & 18 & 2 & 0.90 & 0.92 & 0.06 \\
\hline Nereis Control & 1 & 16 & 4 & 0.80 & & \\
\hline Nereis Control & 2 & 14 & 6 & 0.70 & & \\
\hline Nereis Control & 3 & 13 & 7 & 0.65 & & \\
\hline Nereis Control & 4 & 18 & 2 & 0.90 & & \\
\hline Nereis Control & 5 & 15 & 5 & 0.75 & 0.76 & 0.10 \\
\hline
\end{tabular}

(a) Survival based on initial exposure of 20 organisms per replicate.

(b) MDRS Mud Dump Reference Site. 
Table E.6 Water Quality Data for 28-Day Bioaccumulation Test with N. virens, Bronx River

\begin{tabular}{|c|c|c|c|c|c|c|c|c|}
\hline \multirow{2}{*}{$\begin{array}{l}\text { Sediment } \\
\text { Treatment }\end{array}$} & \multicolumn{2}{|c|}{$\begin{array}{c}\text { Temperature } \\
\left({ }^{\circ} \mathrm{C}\right) \\
\end{array}$} & \multicolumn{2}{|c|}{$\mathrm{pH}$} & \multicolumn{2}{|c|}{$\begin{array}{c}\text { Dissolved } \\
\text { Oxygen } \\
\text { (mg/L) }\end{array}$} & \multicolumn{2}{|c|}{$\begin{array}{c}\text { Salinity } \\
(\% \circ)\end{array}$} \\
\hline & Min & $\operatorname{Max}$ & Min & Max & Min & Max & Min & Max \\
\hline Acceptable Range: & 18.0 & 22.0 & 7.30 & 8.30 & 4.6 & $N A^{(a)}$ & 28.0 & 32.0 \\
\hline BX COMP & 19.0 & 20.3 & 7.78 & 8.09 & 5.6 & 7.0 & 30.0 & 30.5 \\
\hline MDRS $^{(b)}$ & 19.0 & 20.3 & 7.81 & 8.08 & 5.8 & 7.3 & 30.0 & 30.5 \\
\hline Nereis Control & 19.1 & 20.3 & 7.70 & 8.17 & 5.2 & 7.2 & 30.0 & 31.0 \\
\hline
\end{tabular}


Table E.7. Results for 96-Hour, Copper Reference Toxicant Test with $N$. virens

\begin{tabular}{cccc}
$\begin{array}{c}\text { Copper } \\
\text { Concentration }(\mu \mathrm{g} / \mathrm{L})\end{array}$ & Live $e^{(\mathrm{a})}$ & $\begin{array}{c}\text { Dead or } \\
\text { Missing }\end{array}$ & $\begin{array}{c}\text { Proportion } \\
\text { Surviving }\end{array}$ \\
\hline 0 & 10 & 0 & 1.00 \\
50 & 10 & 0 & 1.00 \\
75 & 10 & 0 & 1.00 \\
100 & 9 & 1 & 0.90 \\
200 & 5 & 5 & 0.50 \\
300 & 3 & 7 & 0.30 \\
400 & 0 & 10 & 0.00
\end{tabular}

(a) Survival based on initial exposure of 10 organisms per replicate 
Table E.8. Water Quality Data for 96-Hour, Copper Reference Toxicant Test with $N$. virens

\begin{tabular}{|c|c|c|c|c|c|c|c|c|}
\hline \multirow{2}{*}{$\begin{array}{c}\text { Copper } \\
\text { Concentration } \\
(\mu g / L) \\
\end{array}$} & \multicolumn{2}{|c|}{$\begin{array}{c}\text { Temperature } \\
\left({ }^{\circ} \mathrm{C}\right) \\
\end{array}$} & \multicolumn{2}{|c|}{$\mathrm{pH}$} & \multicolumn{2}{|c|}{$\begin{array}{c}\text { Dissolved } \\
\text { Oxygen } \\
\text { (mg/L) }\end{array}$} & \multicolumn{2}{|c|}{$\begin{array}{c}\text { Salinity } \\
(\% 0)\end{array}$} \\
\hline & Min & Max & Min & Max & Min & Max & Min & Max \\
\hline Acceptable Range: & 18.0 & 22.0 & 7.30 & 8.30 & 4.6 & $N A^{(a)}$ & 28.0 & 32.0 \\
\hline 0 & 18.6 & 18.9 & 7.94 & 8.12 & 6.9 & 7.4 & 30.5 & 31.5 \\
\hline 50 & 18.6 & 18.9 & 7.86 & 8.09 & 6.7 & 7.3 & 30.5 & 31.5 \\
\hline 75 & 18.7 & 18.9 & 7.82 & 8.07 & 6.5 & 7.4 & 30.5 & 31.5 \\
\hline 100 & 18.7 & 18.9 & 7.66 & 8.07 & 5.5 & 7.3 & 30.5 & 31.5 \\
\hline 200 & 18.6 & 18.8 & 7.45 & 8.07 & $3.1^{\text {(b) }}$ & 7.4 & 30.5 & 31.5 \\
\hline 300 & 18.7 & 18.9 & 7.32 & 8.01 & $2.2^{(b)}$ & 7.2 & 30.5 & 31.5 \\
\hline 400 & 18.7 & 18.9 & 7.23 & 7.97 & $1.6^{(b)}$ & 7.4 & 30.5 & 31.5 \\
\hline
\end{tabular}
(a) NA Not applicable.
(b) Data point out of range. 


\section{Appendix F}

\section{Macoma nasuta Tissue Chemical Analyses and Quality Assurance/Quality Control Data, Bronx River Project}





\section{QA/QC SUMMARY}

PROGRAM: $\quad$ New York Federal Projects 5

PARAMETER: Metals

LABORATORY: Battelle/Marine Sciences Laboratory, Sequim, Washington

MATRIX: $\quad$ Clam Tissue

QAVC DATA QUALITY OBJECTIVES

\begin{tabular}{|c|c|c|c|c|c|}
\hline & $\begin{array}{c}\text { Reference } \\
\text { Method }\end{array}$ & $\begin{array}{l}\text { Range of } \\
\text { Recovery }\end{array}$ & $\begin{array}{c}\text { SRM } \\
\text { Accuracy }\end{array}$ & $\begin{array}{r}\text { Relative } \\
\text { Precision }\end{array}$ & $\begin{array}{c}\text { Target } \\
\text { Detection } \\
\text { Limit(dry wt) }\end{array}$ \\
\hline Arsenic & ICP/MS & $75-125 \%$ & $\leq 20 \%$ & $\leq 20 \%$ & $1.0 \mathrm{mg} / \mathrm{kg}$ \\
\hline Cadmium & ICP/MS & $75-125 \%$ & $\leq 20 \%$ & $\leq 20 \%$ & $0.1 \mathrm{mg} / \mathrm{kg}$ \\
\hline Chromium & ICP/MS & $75-125 \%$ & $\leq 20 \%$ & $\leq 20 \%$ & $0.2 \mathrm{mg} / \mathrm{kg}$ \\
\hline Copper & ICP/MS & $75-125 \%$ & $\leq 20 \%$ & $\leq 20 \%$ & $1.0 \mathrm{mg} / \mathrm{kg}$ \\
\hline Lead & ICP/MS & $75-125 \%$ & $\leq 20 \%$ & $\leq 20 \%$ & $0.1 \mathrm{mg} / \mathrm{kg}$ \\
\hline Mercury & CVAA & $75-125 \%$ & $\leq 20 \%$ & $\leq 20 \%$ & $0.02 \mathrm{mg} / \mathrm{kg}$ \\
\hline Nickel & ICP/MS & $75-125 \%$ & $\leq 20 \%$ & $\leq 20 \%$ & $0.1 \mathrm{mg} / \mathrm{kg}$ \\
\hline Silver & ICP/MS & $75-125 \%$ & $\leq 20 \%$ & $\leq 20 \%$ & $0.1 \mathrm{mg} / \mathrm{kg}$ \\
\hline Zinc & ICP/MS & $75-125 \%$ & $\leq 20 \%$ & $\leq 20 \%$ & $1.0 \mathrm{mg} / \mathrm{kg}$ \\
\hline
\end{tabular}

METHOD

Nine metals were analyzed for the New York 5 Program: silver $(\mathrm{Ag})$, arsenic (As), cadmium (Cd), chromium (Cr), copper (Cu), mercury ( $\mathrm{Hg})$, nickel $(\mathrm{Ni})$, lead $(\mathrm{Pb})$ and zinc $(\mathrm{Zn})$. Hg was analyzed using cold-vapor atomic absorption spectroscopy (CVAA) according to the method of Bloom and Crecelius (1983). The remaining metals were analyzed by inductively coupled plasma mass spectrometry (ICP/MS) following a procedure based on EPA Method 200.8 (EPA 1991).

To prepare tissue for analysis, samples were freeze-dried and blended in a Spex mixer-mill. Approximately $5 \mathrm{~g}$ of mixed sample was ground in a ceramic ball mill. For ICP/MS and CVAA analyses, $0.2-$ to $0.5-\mathrm{g}$ aliquots of dried homogenous sample were digested using a mixture of nitric acid and hydrogen peroxide following a modified version of EPA Method 200.3 (EPA 1991).

HOLDING TIMES Tissue samples were received on 7/13/95 in good condition. Samples were entered into Battelle's log-in system, frozen to $-80^{\circ} \mathrm{C}$, and subsequently freeze dried within approximately 7 days of sample receipt. Samples were analyzed within 180 days of collection. 
QA/QC SUMMARY METALS (continued)

The following table summarizes the analysis dates:

Task

Sample Digestion

Date Performed

ICP-MS

$8 / 15 / 95$

CVAA-Hg

$8 / 29 / 95$

$8 / 23 / 95$

DETECTION LIMITS

METHOD BLANKS

MATRIX SPIKES

REPLICATES
SRMs
Target detection limits were met for all metals except $\mathrm{Ag}, \mathrm{Cu}, \mathrm{Ni}$ and $\mathrm{Zn}$; however, all sample values for these metals were above the achieved method detection limit (MDL). MDLs were determined by spiking seven replicates of the reagent blank and multiplying the standard deviation of the resulting analyses by the student's t-value at the 99th percentile $(t=3.142)$.

One procedural blank was analyzed per 20 samples. No metals were detected in the blanks above the MDLs with the exception of $\mathrm{Hg}$, which was detected at a concentration less than three times the target detection limit. All data were blank corrected.

One sample was spiked with all metals at a frequency of 1 per 20 samples. All recoveries were within the QC limits of $75-125 \%$.

Two samples were analyzed in triplicate at a frequency of 1 per 20 samples. Background clam tissue samples were also analyzed in triplicate. Precision for triplicate analyses was reported by calculating the relative standard deviation (RSD) between the replicate results. RSDs were within the QC limits of $\pm 20 \%$ for all metals with the exception of $\mathrm{Pb}$ in one set of triplicates ( $41 \% \mathrm{RSD}$ ) and $\mathrm{Cr}$ ( $26 \% \mathrm{RSD}), \mathrm{Cu}$ ( $88 \% \mathrm{RSD})$, and $\mathrm{Pb}(41 \% \mathrm{RSD})$ in the set of background tissue triplicates. In all cases, only one of the three replicates was variable, with the other two replicates in good agreement. Therefore, no data were flagged or qualified.

SRM 1566a, oyster tissue from the National Institute of Standards and Technology (NIST), was analyzed in duplicate at a frequency of 1 per 20 samples. Results for all metals were within $\pm 20 \%$ of mean certified value with the exception of $\mathrm{Ni}$ in one replicate and $\mathrm{Cr}$ in both. Cr was not detected above the MDL in either SRM sample, and the Ni values were variable. The digestion used on these samples may not be rigorous enough to completely digest the form of $\mathrm{Cr}$ present in this SRM. 
QA/QC SUMMARY METALS (continued)

\section{REFERENCES}

Bloom, N. S., and E.A. Crecelius. 1983. Determination of Mercury in Seawater at SubNanogram per Liter Levels. Mar. Chem. 14:49-59.

EPA (U.S. Environmental Protection Agency). 1991. Methods for the Determination of Metals in Environmental Samples. EPA-600/4-91-010. U.S. Environmental Protection Agency, Environmental Services Division, Monitoring Management Branch, Washington D.C. 


\section{QA/QC SUMMARY}

PROGRAM:

PARAMETER:

LABORATORY:

MATRIX:
New York Federal Projects 5

Chlorinated Pesticides/PCB Congeners

Battelle/Marine Sciences Laboratory, Sequim, Washington

\section{QA/QC DATA QUALITY OBJECTIVES}

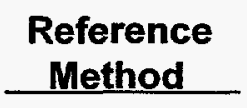

GC/ECD

\author{
Surrogate \\ Recovery
}

$30-150 \%$

\section{Spike \\ Recovery}

$50-120 \%$

\section{Relative}

Precision

$\leq 30 \%$

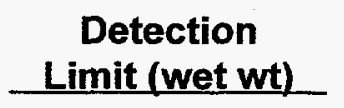

$0.4 \mu \mathrm{g} / \mathrm{kg}$

METHOD

HOLDING TIMES

Tissues were homogenized wet using a stainless steel blade. An aliquot of tissue sample was extracted with methylene chloride using the roller technique under ambient conditions following a procedure based on methods used by the National Oceanic and Atmospheric Administration for its Status and Trends Program (NOAA 1993). Samples were then cleaned using silica/alumina ( $5 \%$ deactivated) chromatography followed by high performance liquid chromatography (HPLC) cleanup. Extracts were analyzed for 15 chlorinated pesticides and 22 PCB congeners using gas chromatography/electron capture detection (GC/ECD) following a procedure based on EPA Method 8080 (EPA 1986). The column used was a J\&W DB-17 and the confirmatory column was a DB1701 , both capillary columns $(30 \mathrm{~m} \times 0.25 \mathrm{~mm}$ I.D. $)$. All detections were quantitatively confirmed on the second column.

Tissue samples were received on 7/13/95 in good condition. Samples were entered into Battelle's log-in system and stored frozen until extraction. Samples were extracted in two batches. The following summarizes the extraction and analysis dates:

\begin{tabular}{|c|c|c|c|}
\hline Batch & Species & Extraction & Analysis \\
\hline 1 & N. virens & 9/28/95 & 10/19-20/95 \\
\hline 2 & M. nasuta/N. virens & $10 / 16 / 95$ & $10 / 20-21 / 95$ \\
\hline
\end{tabular}

One sample, MDRS Replicate 5, was broken during processing. No additional tissue was available for reextraction, so no results are reported for this sample. 


\section{QA/QC SUMMARYIPCBS and PESTICIDES (continued)}

DETECTION LIMITS

METHOD BLANKS

SURROGATES

MATRIX SPIKES

REPLICATES

SRMs

MISCELLANEOUS
Target detection limits of $0.4 \mu \mathrm{g} / \mathrm{kg}$ wet weight were met for most pesticides and PCB congeners. Three samples that were reextracted due to low initial surrogate recoveries had high detection limits for all compounds. Detection limits were higher for these samples because a smaller sample size was used for the reextraction, due to limited availability of remaining tissue. Method detection limits (MDLs) reported were determined by multiplying the standard deviation of seven spiked replicates of worm tissue by the student's $t$-value at the 99th percentile $(t=3.142)$. The reported MDLs were corrected for individual sample wet weight.

One method blank was extracted with each extraction batch. No pesticides or PCBs were detected in any of the method blanks, with the exception of aldrin in the blank from batch 1 . The amount in the blank was less than three times the MDL; therefore, no further action was taken.

Two compounds, PCB congeners 103 and 198, were added to all samples prior to extraction to assess the efficiency of the analysis. Sample surrogate recoveries were all within the QC guidelines of $30 \%-120 \%$. Sample results were quantified based on surrogate recoveries.

Eleven out of the 15 pesticides and 5 of the 22 PCB congeners analyzed were spiked into one sample per extraction batch. Matrix spike recoveries were within the control limit range of $50 \%-120 \%$ for all pesticides and PCBs, with the exception of PCB 28 (146\%) in batch 2 .

One sample from each extraction batch was analyzed in triplicate. Precision was measured by calculating the relative standard deviation (RSD) between the replicate results. RSDs for all detectable values were below the target precision goal of $\leq 30 \%$.

An appropriate SRM for chlorinated organics in tissues was not available from NIST at the time of these analyses.

All pesticide and $\mathrm{PCB}$ congener results are confirmed using a second dissimilar column. RSDs between the primary and confirmation values must be less than $75 \%$ to be considered a confirmed value. 


\section{QA/QC SUMMARYIPCBs and PESTICIDES (continued)}

\section{REFERENCES}

NYSDEC (New York Department of Environmental Conservation). 1992. Analytical Method for the Determination of PCB congeners by Fused Silica Capillary Column Gas Chromatography with Electron Capture Detector. NYSDEC Method 91-11. New York State Department of Environmental Conservation, Albany, New York.

EPA (U.S. Environmental Protection Agency). 1986. Test Methods for Evaluating Solid Waste: Physical/Chemical Methods. SW-846. U.S. Document No. 955-001-00000, U.S. Environmental Protection Agency, Washington D. C. 


\section{QA/QC SUMMARY}
PROGRAM:
New York Federal Projects 5
PARAMETER:
Polynuclear Aromatic Hydrocarbons (PAH) and 1,4-Dichlorobenzene
LABORATORY:
Battelle/Marine Sciences Laboratory, Sequim, Washington
MATRIX:
Clam Tissue

QA/QC DATA QUALITY OBJECTIVES

\begin{tabular}{|c|c|c|c|c|c|}
\hline $\begin{array}{l}\text { Reference } \\
\text { Method }\end{array}$ & $\begin{array}{c}\text { MS } \\
\text { Recovery }\end{array}$ & $\begin{array}{l}\text { Surrogate } \\
\text { Recovery }\end{array}$ & $\begin{array}{c}\text { SRM } \\
\text { Accuracy }\end{array}$ & $\begin{array}{l}\text { Relative } \\
\text { Precision }\end{array}$ & $\begin{array}{l}\text { Detection } \\
\text { Limit (wet wt }\end{array}$ \\
\hline & & & $\leq 30 \%$ & $30 \%$ & \\
\hline
\end{tabular}

METHOD

HOLDING TIMES
Tissue samples were extracted with methylene chloride following a procedure based on methods used by the National Oceanic and Atmospheric Administration for its Status and Trends Program (NOAA 1993). Samples were then cleaned using silica/alumina ( $5 \%$ deactivated) chromatography followed by high performance liquid chromatography (HPLC) cleanup.

Extracts were quantified using gas chromatography/mass spectrometry (GC/MS) in the selected ion mode (SIM) following a procedure based on EPA Method 8270 (NOAA 1993).

Tissue samples were received on 7/13/95 in good condition. Samples were entered into Battelle's log-in system and stored frozen until extraction. The following summarizes the extraction and analysis dates:

\begin{tabular}{llll} 
Batch & Species & Extraction & Analysis \\
\cline { 2 - 3 } & N. virens & $9 / 28 / 95$ & $10 / 19-20 / 95$ \\
2 & M. nasuta/N. virens & $10 / 16 / 95$ & $10 / 20-21 / 95$
\end{tabular}

One sample, MDRS Replicate 5, was broken during processing. No additional tissue was available for reextraction, so no results are reported for this sample. 
DETECTION LIMITS

METHOD BLANKS

\section{SURROGATES}

MATRIX SPIKES

REPLICATES
Target detection limits of $4 \mu \mathrm{g} / \mathrm{kg}$ wet weight were met for all PAH compounds except for fluoranthene and pyrene, which had method detection limits (MDL) between 4 and $6 \mu \mathrm{g} / \mathrm{kg}$ wet weight. MDLs were determined by multiplying the standard deviation of seven spiked replicates of a background clam sample by the student's t-value at the 99th percentile ( $t=3.142)$. These MDLs were based on a wet weight of 20 grams of tissue sample. Aliquots of samples that were analyzed in triplicate, used for spiking, or were reextracted, were generally less than $\mathbf{2 0}$ grams due to limited quantities of tissue available. Because MDLs reported are corrected for sample weight, the MDLs reported for these samples appear elevated and in some cases may exceed the target detection limit.

One method blank was extracted with each extraction batch. A number the high molecular weight PAHs were detected in the blank analyzed with batch 1 , however, all values were less than three times the MDL. Only one PAH analyzed with batch 2, benz[a]anthracene, was detected at less than three times the MDL. Sample values that were less than five times the blank concentration were reported and flagged with a "B" to indicate that those values could be biased high due to blank contamination. Sample values greater than five times the blank concentration were considered unaffected by the blank contamination and were therefore not flagged.

Five isotopically labeled compounds were added prior to extraction to assess the efficiency of the method. These were d8-naphthalene, d10acenaphthene, d12-chrysene, d14-dibenz[a,h]anthracene and d4-1,4 dichlorobenzene. Recoveries of all surrogates were within the quality control limits of $30 \%-150 \%$ with the exception of d14dibenz[a,h]anthracene in three samples from batch 1, d14dibenz[a,h]anthracene in two samples from batch 2 , and d8naphthalene in one sample from batch 2 . Of these low recoveries, all but two were above $20 \%$. Results were quantified using the surrogate internal standard method.

One sample from each batch was spiked with all PAH compounds. Matrix spike recoveries were within QC limits of $50 \%-120 \%$, with the exception of benzo[b]fluoranthene $(248 \%)$ and naphthalene $(121 \%)$ in one sample.

One sample from each batch was extracted and analyzed in triplicate. Precision was measured by calculating the relative standard deviation (RSD) between the replicate results. All RSDs for detectable compounds were within $\pm 30 \%$. 


\section{QA/QC SUMMARYIPAHs (continued)}

SRMs

MISCELLANEOUS
An appropriate SRM for PAHs in tissues was not available from NIST at the time of these analyses.

For several compounds the ion-ratio was outside of the QC range, due to low levels in the native sediment. When the native levels are low, the error associated with the concentration measurement of the confirmation ion, which is present at a fraction of the parent ion concentration, increases. Because the confirmation ion is quantified solely from the parent ion, this will not affect the quality of the data.

\section{REFERENCES}

NOAA (National Oceanic and Atmospheric Administration). 1993. Sampling and Analytical Methods of the National Status and Trends Program, National Benthic Surveillance and Mussel Watch Projects 1984-1992. Volume IV. Comprehensive Descriptions of Trace Organic Analytical Methods. G.G. Lauenstein and A.Y. Cantillo, eds. NOAA Technical Memorandum NOS ORCA 71. National Oceanic and Atmospheric Administration, Coastal Monitoring and Bioeffects Assessment Division, Office of Resources Conservation and Assessment, Silver Spring, Maryland.

EPA (U.S. Environmental Protection Agency). 1986. Test Methods for Evaluating Solid Waste: Physical/Chemical Methods. SW-846. U.S. Document No. 955-001-00000, U.S. Environmental Protection Agency, Washington D.C. 

Table F.1. Metals in M. nasuta Tissue (Wet Weight), Bronx River

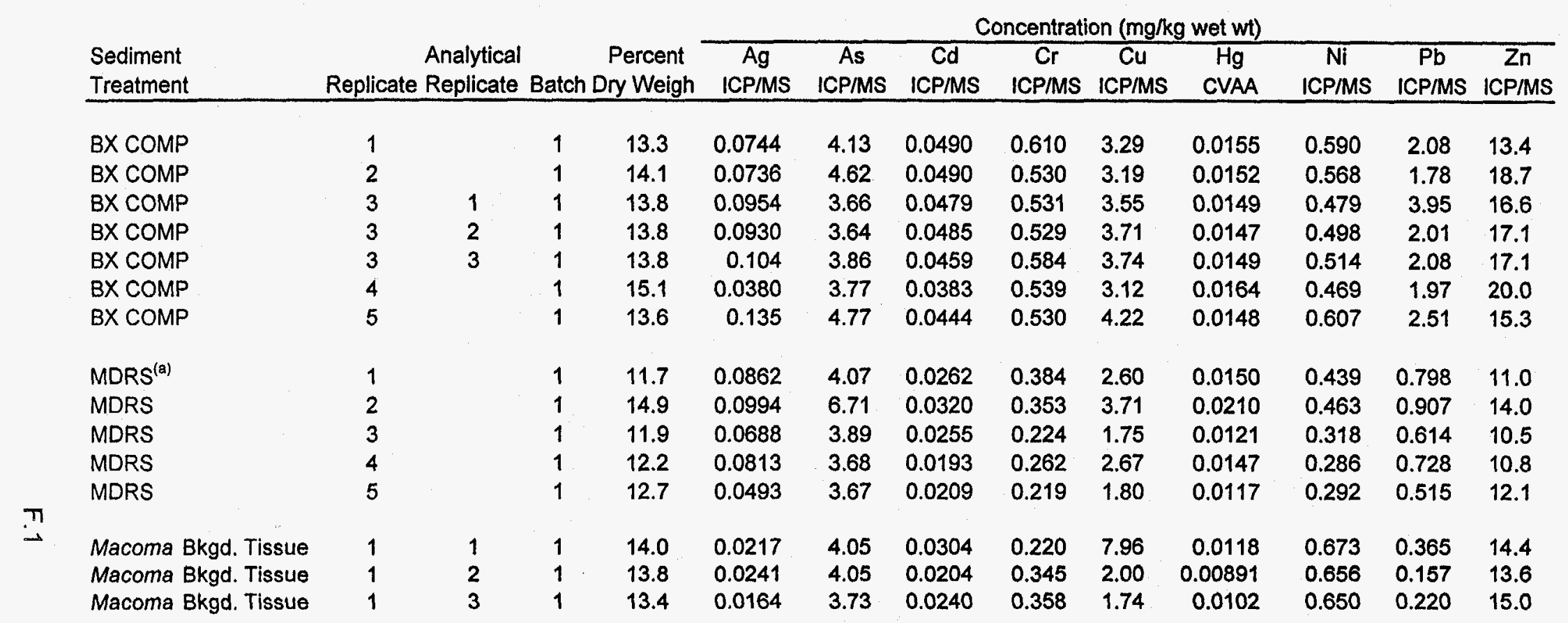

(a) MDRS Mud Dump Reference Site. 
Table F.2. Metals in M. nasuta Tissue (Dry Weight), Bronx River

\begin{tabular}{|c|c|c|c|c|c|c|c|c|c|c|c|c|c|c|}
\hline & \multirow{2}{*}{\multicolumn{2}{|c|}{$\begin{array}{l}\text { Sediment } \\
\text { Treatment }\end{array}$}} & \multirow[b]{2}{*}{$\begin{array}{l}\text { Analytical } \\
\text { Replicate }\end{array}$} & \multirow[b]{2}{*}{ Batch } & \multirow[b]{2}{*}{$\begin{array}{c}\text { Percent } \\
\text { Dry Weight }\end{array}$} & \multicolumn{9}{|c|}{ Concentration (mg/kg dry wt) } \\
\hline & & & & & & $\begin{array}{c}\mathrm{Ag} \\
\mathrm{ICP} / \mathrm{MS}\end{array}$ & $\begin{array}{c}\text { As } \\
\text { ICPMS }\end{array}$ & $\begin{array}{c}\text { Cd } \\
\text { ICP/MS }\end{array}$ & $\begin{array}{c}\mathrm{Cr} \\
\text { ICPMS }\end{array}$ & $\begin{array}{c}\mathrm{Cu} \\
\mathrm{ICP} / \mathrm{MS}\end{array}$ & $\begin{array}{c}\mathrm{Hg} \\
\text { CVAA }\end{array}$ & $\begin{array}{c}\mathrm{Ni} \\
\text { ICP/MS }\end{array}$ & $\begin{array}{c}\mathrm{Pb} \\
\text { ICPMS }\end{array}$ & $\begin{array}{c}\mathrm{Zn} \\
\text { ICP/MS }\end{array}$ \\
\hline & \multicolumn{5}{|c|}{ Target Detection Limit: } & 0.1 & 1.0 & 0.1 & 0.2 & 1.0 & 0.02 & 0.1 & 0.1 & 1.0 \\
\hline & \multicolumn{5}{|c|}{ Method Detection Limit: } & 0.22 & 0.830 & 0.081 & 0.0845 & 1.20 & 0.0011 & 0.25 & 0.08 & 1.37 \\
\hline & $\mathrm{BX}$ COMP & 1 & & 1 & 13.3 & 0.560 & 31.1 & 0.369 & 4.59 & 24.8 & 0.117 & 4.44 & 15.7 & 101 \\
\hline & $\mathrm{BX}$ COMP & 2 & & 1 & 14.1 & 0.524 & 32.9 & 0.349 & 3.77 & 22.7 & 0.108 & 4.04 & 12.7 & 133 \\
\hline & $B \times C O M P$ & 3 & 1 & 1 & 13.8 & 0.694 & 26.6 & 0.348 & 3.86 & 25.8 & 0.108 & 3.48 & 28.7 & 121 \\
\hline & $\mathrm{BX}$ COMP & 3 & 2 & 1 & 13.8 & 0.676 & 26.5 & 0.353 & 3.85 & 27.0 & 0.107 & 3.62 & 14.6 & 124 \\
\hline & BX COMP & 3 & 3 & 1 & 13.8 & 0.753 & 28.1 & 0.334 & 4.25 & 27.2 & 0.108 & 3.74 & 15.1 & 124 \\
\hline & $B X$ COMP & 4 & & 1 & 15.1 & 0.251 & 24.9 & 0.253 & 3.56 & 20.6 & 0.108 & 3.10 & 13.0 & 132 \\
\hline & $B X C O M P$ & 5 & & 1 & 13.6 & 0.990 & 35.0 & 0.326 & 3.89 & 31.0 & 0.109 & 4.46 & 18.4 & 112 \\
\hline & $\operatorname{MDRS}^{(a)}$ & 1 & & 1 & 11.7 & 0.737 & 34.8 & 0.224 & 3.28 & 22.2 & 0.128 & 3.75 & 6.82 & 93.6 \\
\hline & MDRS & 2 & & 1 & 14.9 & 0.667 & 45.0 & 0.215 & 2.37 & 24.9 & 0.141 & 3.11 & 6.09 & 94.0 \\
\hline & MDRS & 3 & & 1 & 11.9 & 0.581 & 32.8 & 0.215 & 1.89 & 14.8 & 0.102 & 2.68 & 5.18 & 89.0 \\
\hline & MDRS & 4 & & 1 & 12.2 & 0.665 & 30.1 & 0.158 & 2.14 & 21.8 & 0.120 & 2.34 & 5.95 & 88.1 \\
\hline & MDRS & 5 & & 1 & 12.7 & 0.390 & 29.0 & 0.165 & 1.73 & 14.2 & 0.0927 & 2.31 & 4.07 & 95.9 \\
\hline & Macoma Bkgd. Tissue & 1 & 1 & 1 & 14.0 & 0.155 & 28.9 & 0.217 & 1.57 & 56.8 & 0.0842 & 4.80 & 2.60 & 103 \\
\hline & Macoma Bkgd. Tissue & 1 & 2 & 1 & 13.8 & 0.175 & 29.4 & 0.148 & 2.50 & 14.5 & 0.0646 & 4.76 & 1.14 & 98.4 \\
\hline & Macoma Bkgd. Tissue & 1 & 3 & 1 & 13.4 & 0.122 & 27.8 & 0.179 & 2.67 & 13.0 & 0.0764 & 4.85 & 1.64 & 112 \\
\hline
\end{tabular}

(a) MDRS Mud Dump Reference Site. 
Table F.3. Quality Control Data for Metals Analysis of M. nasuta Tissue (Dry Weight)

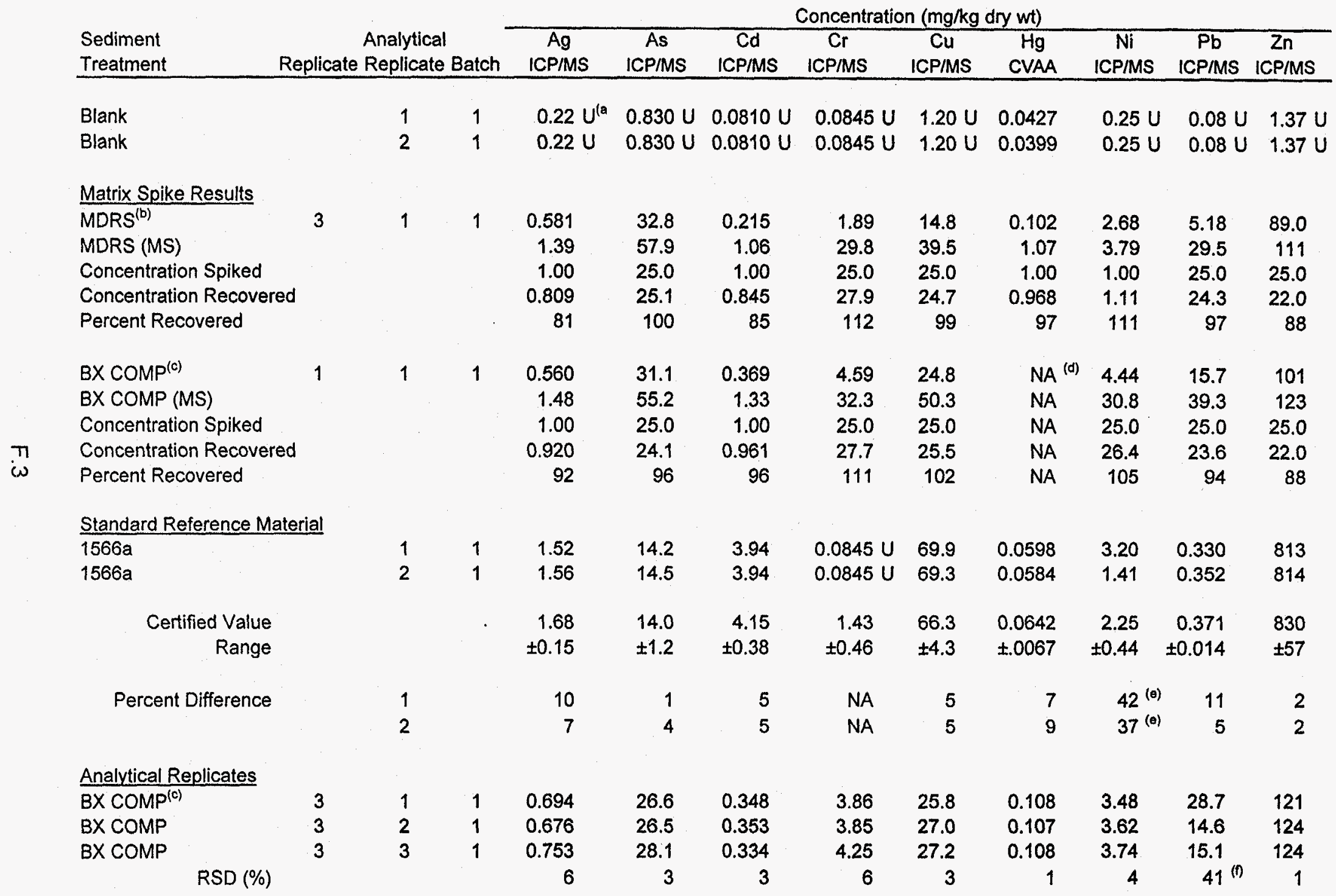


Table F.3. (contd)

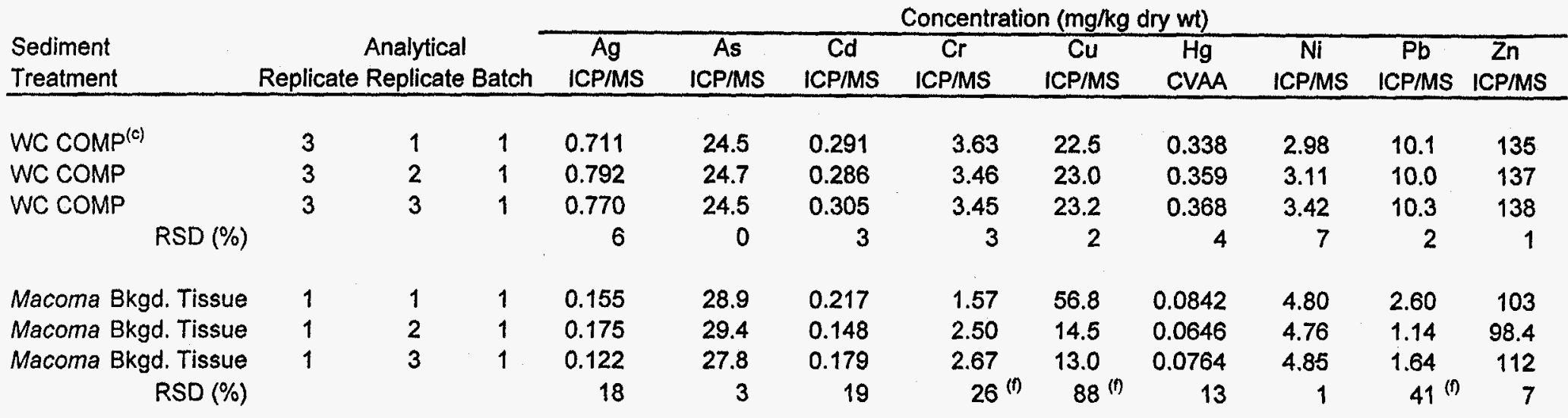

(a) U Undetected at or above given concentration.

(b) MDRS Mud dump reference site.

(c) Sample randomly selected for use as a quality control sample in analytical batch.

$\pi \quad$ (d) NA Not applicable.

(e) Outside SRM quality control criteria $(\leq 20 \%)$.

(f) Outside quality control criteria $(\leq 20 \%)$ for replicate analysis. 
Table F.4. Pesticides and Polychlorinated Biphenyls (PCBs) in Tissue of $M$. nasuta (Wet Weight), Bronx River

\begin{tabular}{|c|c|c|c|c|c|}
\hline \multirow{3}{*}{$\begin{array}{l}\text { Sediment Treatment } \\
\text { Replicate }\end{array}$} & \multicolumn{5}{|c|}{ Concentration $(\mu \mathrm{g} / \mathrm{kg}$ wet $w \mathrm{t})$} \\
\hline & BX COMP & BX COMP & BX СОMP & BX COMP & BX COMP \\
\hline & 1 & 2 & 3 & 3 & 3 \\
\hline Analytical Replicate & & & 1 & 2 & 3 \\
\hline Wet Weight (g) & 20.2 & 20.1 & 9.57 & 9.79 & 10.3 \\
\hline Percent Dry Weight & 13.3 & 14.1 & 13.8 & 13.8 & 13.8 \\
\hline Batch & 2 & 2 & 1 & 1 & 1 \\
\hline $2,4^{\prime}-\mathrm{DDD}^{(\mathrm{a})}$ & 0.64 & 0.76 & $0.53 \mathrm{U}^{(\mathrm{b})}$ & $0.52 \mathrm{U}$ & $0.49 \mathrm{U}$ \\
\hline 2,4'-DDE & $0.26 \mathrm{U}$ & $0.26 \mathrm{U}$ & $0.54 \mathrm{U}$ & $0.53 \mathrm{U}$ & $0.51 \mathrm{U}$ \\
\hline 2,4'-DDT & $0.18 \mathrm{U}$ & $0.18 U$ & $0.37 \mathrm{U}$ & $0.37 \mathrm{U}$ & $0.35 \mathrm{U}$ \\
\hline 4,4'-DDD & 2.83 & 3.52 & 3.11 & 2.77 & 2.82 \\
\hline 4,4'-DDE & 2.71 & 3.26 & 3.57 & 3.12 & 3.13 \\
\hline 4,4'-DDT & 1.57 & 1.61 & 1.36 & 0.94 & 0.94 \\
\hline$\alpha$-Chlordane & 2.34 & 3.06 & 2.09 & 1.85 & 2.01 \\
\hline Aldrin & 1.76 & 1.92 & 2.01 & 1.88 & 1.86 \\
\hline Dieldrin & 1.69 & 1.88 & 1.74 & 1.53 & 1.68 \\
\hline Endosulfan I & $0.18 \mathrm{U}$ & $0.18 \mathrm{U}$ & $0.37 \mathrm{U}$ & $0.37 \mathrm{U}$ & $0.35 \mathrm{U}$ \\
\hline Endosulfan II & $0.18 U$ & $0.18 U$ & $0.37 \mathrm{U}$ & $0.37 \mathrm{U}$ & $0.35 \mathrm{U}$ \\
\hline Endosulfan Sulfate & $0.25 \mathrm{U}$ & $0.25 \mathrm{U}$ & $0.53 \mathrm{U}$ & $0.52 \mathrm{U}$ & $0.49 \mathrm{U}$ \\
\hline Heptachlor & 0.51 & 0.21 & $0.38 U$ & $0.38 \mathrm{U}$ & $0.36 \mathrm{U}$ \\
\hline Heptachlor Epoxide & $0.13 U$ & $0.13 \mathrm{U}$ & $0.28 \mathrm{U}$ & $0.27 \mathrm{U}$ & $0.26 \mathrm{U}$ \\
\hline Trans Nonachlor & 0.63 & 0.89 & $0.30 \mathrm{U}$ & $0.30 \mathrm{U}$ & $0.28 \mathrm{U}$ \\
\hline РСВ 8 & 5.14 & 4.73 & 3.16 & 2.61 & 2.57 \\
\hline РСB 18 & 9.52 & 9.26 & 6.77 & 5.71 & 5.79 \\
\hline РСВ 28 & 8.00 & 7.72 & 8.97 & 8.38 & 7.96 \\
\hline РСВ 44 & $0.07 \mathrm{U}$ & $0.07 \mathrm{U}$ & $0.15 \mathrm{U}$ & $0.14 \mathrm{U}$ & $0.14 \mathrm{U}$ \\
\hline РCB 49 & 4.63 & 4.99 & 3.45 & 3.10 & 3.11 \\
\hline РСВ 52 & 6.92 & 7.17 & 5.89 & 5.27 & 5.32 \\
\hline РСВ 66 & 4.58 & 4.90 & 4.39 & 3.75 & 3.86 \\
\hline РСB 87 & 0.92 & 1.04 & 0.79 & 0.53 & 0.60 \\
\hline PCB 101 & 3.94 & 4.21 & 3.43 & 2.90 & 3.05 \\
\hline PCB 105 & 0.87 & 0.96 & $0.35 \mathrm{U}$ & $0.34 \mathrm{U}$ & $0.32 \mathrm{U}$ \\
\hline PCB 118 & 2.42 & 2.59 & 1.94 & 1.56 & 1.61 \\
\hline PCB 128 & 0.21 & 0.23 & $0.22 \mathrm{U}$ & $0.21 \mathrm{U}$ & $0.20 \mathrm{U}$ \\
\hline РСВ 138 & 2.04 & 3.34 & 1.64 & 1.32 & 1.40 \\
\hline PCB 153 & 2.65 & 3.03 & 2.56 & 2.01 & 2.03 \\
\hline РСВ 170 & $0.18 \mathrm{U}$ & $0.18 \mathrm{U}$ & $0.37 \mathrm{U}$ & $0.36 \mathrm{U}$ & $0.34 \mathrm{U}$ \\
\hline PCB 180 & 0.69 & 0.69 & $0.78 \mathrm{U}$ & $0.77 \mathrm{U}$ & $0.73 \mathrm{U}$ \\
\hline PCB 183 & $0.18 U$ & $0.18 \mathrm{U}$ & $0.38 \mathrm{U}$ & $0.37 \mathrm{U}$ & $0.36 \mathrm{U}$ \\
\hline PCB 184 & $0.18 \mathrm{U}$ & $0.18 U$ & $0.38 \mathrm{U}$ & $0.37 \mathrm{U}$ & $0.36 \mathrm{U}$ \\
\hline PCB 187 & 0.96 & $0.21 \mathrm{U}$ & $0.43 \mathrm{U}$ & $0.42 \mathrm{U}$ & $0.40 \mathrm{U}$ \\
\hline РCB 195 & $0.13 U$ & $0.13 \mathrm{U}$ & $0.26 \mathrm{U}$ & $0.26 \mathrm{U}$ & $0.25 \mathrm{U}$ \\
\hline РСВ 206 & $0.21 U$ & $0.21 \mathrm{U}$ & $0.45 \mathrm{U}$ & $0.44 \mathrm{U}$ & $0.42 \mathrm{U}$ \\
\hline PCB 209 & $0.20 \mathrm{U}$ & $0.20 \mathrm{U}$ & $0.41 \mathrm{U}$ & $0.40 \mathrm{U}$ & $0.38 \mathrm{U}$ \\
\hline \multicolumn{6}{|c|}{ Surrogate Recoveries (\%) } \\
\hline PCB 103 (SIS) & 51 & 64 & 80 & 82 & 83 \\
\hline PCB 198 (SIS) & 37 & 50 & 74 & 73 & 76 \\
\hline
\end{tabular}


Table F.4. (contd)

\begin{tabular}{|c|c|c|c|c|c|}
\hline \\
\hline $\begin{array}{l}\text { Sediment Treatment } \\
\text { Replicate }\end{array}$ & $\begin{array}{c}\mathrm{BX} \text { COMP } \\
4\end{array}$ & $\begin{array}{c}\mathrm{BX} \text { COMP } \\
5\end{array}$ & $\begin{array}{c}\text { MDRS }^{(\mathrm{C})} \\
1\end{array}$ & $\begin{array}{c}\text { MDRS } \\
2\end{array}$ & $\begin{array}{c}\text { MDRS } \\
3\end{array}$ \\
\hline \multicolumn{6}{|l|}{ Analytical Replicate } \\
\hline Wet Weight (g) & 13.3 & 10.0 & 20.1 & 15.2 & 10.4 \\
\hline Percent Dry Weight & 15.1 & 13.6 & 11.7 & 14.9 & 11.9 \\
\hline Batch & 1 & 1 & 1 & 2 & 1 \\
\hline 2,4'-DDD & 0.61 & $0.51 \mathrm{U}$ & $0.25 \mathrm{U}$ & $0.33 \mathrm{U}$ & $0.49 \mathrm{U}$ \\
\hline 2,4'-DDE & $0.39 \mathrm{U}$ & $0.52 \mathrm{U}$ & $0.26 \mathrm{U}$ & $0.34 \mathrm{U}$ & $0.50 \mathrm{U}$ \\
\hline 2,4-DDT & $0.27 \mathrm{U}$ & $0.36 \mathrm{U}$ & $0.18 U$ & $0.24 U$ & $0.34 \mathrm{U}$ \\
\hline 4,4'-DDD & 3.88 & 3.22 & 1.11 & $0.34 \mathrm{U}$ & 1.58 \\
\hline 4,4'-DDE & 4.02 & 3.38 & 1.81 & 1.61 & 2.26 \\
\hline 4,4'-DDT & 1.27 & 1.14 & $0.15 \mathrm{U}$ & 0.91 & 0.89 \\
\hline$\alpha$-Chlordane & 2.80 & 1.83 & 0.11 & 0.14 & $0.18 \mathrm{U}$ \\
\hline Aldrin & 2.12 & 1.84 & 0.89 & 1.21 & 1.35 \\
\hline Dieldrin & 1.90 & 1.65 & $0.52 \mathrm{U}$ & $0.68 \mathrm{U}$ & $0.99 \mathrm{U}$ \\
\hline Endosulfan I & $0.27 \mathrm{U}$ & $0.36 \mathrm{U}$ & $0.18 \mathrm{U}$ & $0.24 U$ & $0.35 U$ \\
\hline Endosulfan II & $0.27 \mathrm{U}$ & $0.36 \mathrm{U}$ & $0.18 \mathrm{U}$ & $0.24 U$ & $0.35 \mathrm{U}$ \\
\hline Endosulfan Sulfate & $0.38 \mathrm{U}$ & $0.51 \mathrm{U}$ & $0.25 \mathrm{U}$ & $0.33 \mathrm{U}$ & $0.49 \mathrm{U}$ \\
\hline Heptachior & $0.28 \mathrm{U}$ & $0.37 \mathrm{U}$ & 0.26 & $0.24 \mathrm{U}$ & 0.53 \\
\hline Heptachlor Epoxide & $0.20 \mathrm{U}$ & $0.27 \mathrm{U}$ & $0.13 \mathrm{U}$ & $0.18 U$ & $0.25 \mathrm{U}$ \\
\hline Trans Nonachlor & 0.97 & 0.52 & $0.15 \mathrm{U}$ & $0.19 \mathrm{U}$ & $0.28 \mathrm{U}$ \\
\hline РCB 8 & 3.99 & 3.11 & $0.35 \mathrm{U}$ & $0.46 \mathrm{U}$ & $0.68 \mathrm{U}$ \\
\hline PCB 18 & 8.98 & 5.53 & $0.10 \mathrm{U}$ & $0.13 \mathrm{U}$ & $0.20 \mathrm{U}$ \\
\hline PCB 28 & 10.6 & 8.59 & 2.16 & 1.51 & 3.03 \\
\hline PCB 44 & 3.01 & $0.14 \mathrm{U}$ & $0.07 \mathrm{U}$ & $0.09 \mathrm{U}$ & $0.14 \mathrm{U}$ \\
\hline РCB 49 & 4.78 & 3.36 & 1.26 & 1.72 & 1.07 \\
\hline PCB 52 & 7.58 & 5.86 & 1.66 & 2.12 & 1.56 \\
\hline PCB 66 & 5.86 & 4.33 & 2.01 & 2.61 & $0.29 \mathrm{U}$ \\
\hline PCB 87 & 1.24 & 0.76 & $0.25 \mathrm{U}$ & $0.33 \mathrm{U}$ & $0.48 \mathrm{U}$ \\
\hline PCB 101 & 4.76 & 3.64 & 1.30 & 1.58 & 1.24 \\
\hline PCB 105 & 0.67 & $0.33 \mathrm{U}$ & $0.17 \mathrm{U}$ & 0.71 & $0.32 \mathrm{U}$ \\
\hline PCB 118 & 2.74 & 1.93 & 0.91 & 1.32 & 0.64 \\
\hline PCB 128 & 0.23 & $0.21 U$ & $0.11 \mathrm{U}$ & $0.14 U$ & $0.20 \mathrm{U}$ \\
\hline PCB 138 & 2.23 & 1.70 & 0.68 & 0.83 & $0.51 \mathrm{U}$ \\
\hline PCB 153 & 3.30 & 2.55 & 0.79 & 0.95 & $0.84 \mathrm{U}$ \\
\hline PCB 170 & 0.37 & $0.35 \mathrm{U}$ & $0.18 \mathrm{U}$ & $0.23 \mathrm{U}$ & $0.34 \mathrm{U}$ \\
\hline PCB 180 & 1.08 & 0.77 & $0.38 \mathrm{U}$ & $0.50 \mathrm{U}$ & $0.72 \mathrm{U}$ \\
\hline PCB 183 & $0.28 \mathrm{U}$ & $0.37 U$ & $0.18 \mathrm{U}$ & $0.24 \mathrm{U}$ & $0.35 \mathrm{U}$ \\
\hline PCB 184 & $0.28 U$ & $0.37 \mathrm{U}$ & $0.18 \mathrm{U}$ & $0.24 U$ & $0.35 \mathrm{U}$ \\
\hline PCB 187 & $0.31 \mathrm{U}$ & $0.41 \mathrm{U}$ & $0.21 \mathrm{U}$ & $0.27 \mathrm{U}$ & $0.40 \mathrm{U}$ \\
\hline PCB 195 & $0.19 \mathrm{U}$ & $0.25 \mathrm{U}$ & $0.13 \mathrm{U}$ & $0.17 U$ & $0.24 \mathrm{U}$ \\
\hline PCB 206 & $0.32 \mathrm{U}$ & $0.43 U$ & $0.21 \mathrm{U}$ & $0.28 \mathrm{U}$ & $0.41 U$ \\
\hline PCB 209 & $0.29 \mathrm{U}$ & $0.39 \mathrm{U}$ & $0.20 \mathrm{U}$ & $0.26 \mathrm{U}$ & $0.37 \mathrm{U}$ \\
\hline \multicolumn{6}{|c|}{ Surrogate Recoveries (\%) } \\
\hline PCB 103 (SIS) & 87 & 84 & 92 & 89 & 81 \\
\hline PCB 198 (SIS) & 80 & 82 & 88 & 73 & 78 \\
\hline
\end{tabular}


Table F.4. (contd)

\begin{tabular}{|c|c|c|c|c|c|}
\hline \multirow{3}{*}{$\begin{array}{l}\text { Sediment Treatment } \\
\text { Replicate }\end{array}$} & \multicolumn{5}{|c|}{ Concentration ( $\mu \mathrm{g} / \mathrm{kg}$ wet $\mathrm{wt}$ ) } \\
\hline & MDRS & MDRS & Macoma Bkgd. & Macoma Bkgd. & Macoma Bkgd. \\
\hline & 4 & 5 & Tissue & Tissue & Tissue \\
\hline Analytical Replicate & & & 1 & 2 & 3 \\
\hline Wet Weight (g) & 20.7 & 20.2 & 14.3 & 10.2 & 10.5 \\
\hline Percent Dry Weight & 12.2 & 12.7 & 13.7 & 13.7 & 13.7 \\
\hline Batch & 1 & 2 & 2 & 2 & 2 \\
\hline 2,4'-DDD & $0.24 U$ & $N A^{(d)}$ & $0.35 U$ & $0.50 \mathrm{U}$ & $0.49 \mathrm{U}$ \\
\hline 2,4'-DDE & $0.25 \mathrm{U}$ & NA & $0.37 \mathrm{U}$ & $0.51 \mathrm{U}$ & $0.50 \mathrm{U}$ \\
\hline 2,4'-DDT & $0.17 \mathrm{U}$ & NA & $0.25 \mathrm{U}$ & $0.35 \mathrm{U}$ & $0.34 \mathrm{U}$ \\
\hline 4,4'-DDD & 1.15 & NA & $0.36 \mathrm{U}$ & $0.51 \mathrm{U}$ & $0.50 \mathrm{U}$ \\
\hline 4,4'-DDE & 2.00 & NA & $0.26 \mathrm{U}$ & $0.37 \mathrm{U}$ & $0.36 \mathrm{U}$ \\
\hline 4,4'-DDT & 0.59 & NA & $0.21 \mathrm{U}$ & $0.30 \mathrm{U}$ & $0.29 \mathrm{U}$ \\
\hline$\alpha$-Chlordane & 0.12 & NA & $0.13 U$ & $0.19 \mathrm{U}$ & $0.18 \mathrm{U}$ \\
\hline Aldrin & 0.93 & NA & $0.18 \mathrm{U}$ & $0.25 \mathrm{U}$ & $0.24 \mathrm{U}$ \\
\hline Dieldrin & $0.49 \mathrm{U}$ & NA & $0.72 \mathrm{U}$ & $1.01 \mathrm{U}$ & $0.99 \mathrm{U}$ \\
\hline Endosulfan I & $0.17 \mathrm{U}$ & NA & $0.25 \mathrm{U}$ & $0.35 \mathrm{U}$ & $0.35 \mathrm{U}$ \\
\hline Endosulfan II & $0.17 \mathrm{U}$ & NA & $0.25 \mathrm{U}$ & $0.35 \mathrm{U}$ & $0.35 \mathrm{U}$ \\
\hline Endosulfan Sulfate & $0.24 \mathrm{U}$ & NA & $0.35 \mathrm{U}$ & $0.50 \mathrm{U}$ & $0.49 \mathrm{U}$ \\
\hline Heptachlor & $0.18 \mathrm{U}$ & NA & $0.26 U$ & $0.36 \mathrm{U}$ & $0.36 \mathrm{U}$ \\
\hline Heptachlor Epoxide & $0.13 \mathrm{U}$ & NA & $0.19 \mathrm{U}$ & $0.26 \mathrm{U}$ & $0.25 \mathrm{U}$ \\
\hline Trans Nonachlor & $0.14 \mathrm{U}$ & NA & $0.20 \mathrm{U}$ & $0.28 \mathrm{U}$ & $0.28 \mathrm{U}$ \\
\hline PCB 8 & $0.34 \mathrm{U}$ & NA & $0.49 \mathrm{U}$ & $0.69 \mathrm{U}$ & $0.68 \mathrm{U}$ \\
\hline РСВ 18 & $0.10 \mathrm{U}$ & NA & $0.14 \mathrm{U}$ & $0.20 \mathrm{U}$ & $0.20 \mathrm{U}$ \\
\hline РСВ 28 & 2.54 & NA & $0.15 \mathrm{U}$ & $0.22 \mathrm{U}$ & $0.21 \mathrm{U}$ \\
\hline РСB 44 & $0.07 \mathrm{U}$ & NA & $0.10 \mathrm{U}$ & $0.14 \mathrm{U}$ & $0.14 \mathrm{U}$ \\
\hline РСВ 49 & 1.34 & NA & $0.26 \mathrm{U}$ & $0.36 \mathrm{U}$ & $0.35 \mathrm{U}$ \\
\hline РCB 52 & 1.60 & NA & $0.45 \mathrm{U}$ & $0.64 \mathrm{U}$ & $0.62 U$ \\
\hline РСВ 66 & 2.31 & NA & $0.21 \mathrm{U}$ & $0.30 \mathrm{U}$ & $0.29 \mathrm{U}$ \\
\hline PCB 87 & 0.27 & NA & $0.35 \mathrm{U}$ & $0.49 \mathrm{U}$ & $0.48 \mathrm{U}$ \\
\hline PCB 101 & 1.64 & NA & $0.19 \mathrm{U}$ & $0.26 \mathrm{U}$ & $0.26 \mathrm{U}$ \\
\hline PCB 105 & $0.16 \mathrm{U}$ & NA & $0.23 \mathrm{U}$ & $0.33 \mathrm{U}$ & $0.32 \mathrm{U}$ \\
\hline PCB 118 & 1.12 & NA & $0.27 \mathrm{U}$ & $0.37 \mathrm{U}$ & $0.37 \mathrm{U}$ \\
\hline PCB 128 & $0.10 \mathrm{U}$ & NA & $0.15 \mathrm{U}$ & $0.21 \mathrm{U}$ & $0.20 \mathrm{U}$ \\
\hline PCB 138 & 0.71 & NA & $0.37 \mathrm{U}$ & $0.52 \mathrm{U}$ & $0.51 \mathrm{U}$ \\
\hline PCB 153 & 0.97 & NA & $0.61 \mathrm{U}$ & $0.86 \mathrm{U}$ & $0.84 \mathrm{U}$ \\
\hline PCB 170 & $0.17 \mathrm{U}$ & NA & $0.25 \mathrm{U}$ & $0.34 \mathrm{U}$ & $0.34 \mathrm{U}$ \\
\hline PCB 180 & $0.36 \mathrm{U}$ & NA & $0.53 \mathrm{U}$ & $0.74 \mathrm{U}$ & $0.72 \mathrm{U}$ \\
\hline PCB 183 & $0.18 \mathrm{U}$ & NA & $0.26 \mathrm{U}$ & $0.36 U$ & $0.35 \mathrm{U}$ \\
\hline PCB 184 & $0.18 \mathrm{U}$ & NA & $0.26 \mathrm{U}$ & $0.36 \mathrm{U}$ & $0.35 \mathrm{U}$ \\
\hline РСВ 187 & $0.20 \mathrm{U}$ & NA & $0.29 \mathrm{U}$ & $0.40 \mathrm{U}$ & $0.40 \mathrm{U}$ \\
\hline PCB 195 & $0.12 \mathrm{U}$ & NA & $0.18 \mathrm{U}$ & $0.25 \mathrm{U}$ & $0.24 \mathrm{U}$ \\
\hline PCB 206 & $0.21 \mathrm{U}$ & NA & $0.30 \mathrm{U}$ & $0.42 \mathrm{U}$ & $0.41 \mathrm{U}$ \\
\hline PCB 209 & $0.19 \mathrm{U}$ & NA & $0.27 \mathrm{U}$ & $0.38 \mathrm{U}$ & $0.37 \mathrm{U}$ \\
\hline \multicolumn{6}{|c|}{ Surrogate Recoveries (\%) } \\
\hline$\overline{P C B} 103$ (SIS) & 83 & NA & 105 & 103 & 104 \\
\hline PCB 198 (SIS) & 78 & NA & 94 & 84 & 88 \\
\hline
\end{tabular}


Table F.5. Pesticides and Polychlorinated Biphenyls (PCBs) in Tissue of M. nasuta (Dry Weight), Bronx River

\begin{tabular}{|c|c|c|c|c|c|}
\hline \multirow{3}{*}{$\begin{array}{l}\text { Sediment Treatment } \\
\text { Replicate }\end{array}$} & \multicolumn{5}{|c|}{ Concentration ( $\mu \mathrm{g} / \mathrm{kg}$ dry $w t)$} \\
\hline & BX COMP & BX COMP & BX COMP & BX COMP & BX COMP \\
\hline & 1 & 2 & 3 & 3 & 3 \\
\hline Analytical Replicate & & & 1 & 2 & 3 \\
\hline Wet Weight (g) & 20.2 & 20.1 & 9.57 & 9.79 & 10.3 \\
\hline Percent Dry Weight & 13.3 & 14.1 & 13.8 & 13.8 & 13.8 \\
\hline Batch & 2 & 2 & 1 & 1 & 1 \\
\hline 2,4'-DDD & 4.8 & 5.4 & $3.9 U^{(a)}$ & $3.8 \mathrm{U}$ & $3.6 \mathrm{U}$ \\
\hline $2,4^{\prime}-\mathrm{DDE}$ & $2.0 \mathrm{U}$ & $1.9 \mathrm{U}$ & $3.9 \mathrm{U}$ & $3.9 \mathrm{U}$ & $3.7 \mathrm{U}$ \\
\hline 2,4'-DDT & $1.4 \mathrm{U}$ & $1.3 \mathrm{U}$ & $2.7 \mathrm{U}$ & $2.7 \mathrm{U}$ & $2.5 \mathrm{U}$ \\
\hline 4,4'-DDD & 21.3 & 25.1 & 22.6 & 20.1 & 20.5 \\
\hline 4,4'-DDE & 20.4 & 23.2 & 26.0 & 22.7 & 22.8 \\
\hline 4,4'-DDT & 11.8 & 11.5 & 9.89 & 6.8 & 6.8 \\
\hline$\alpha$-Chlordane & 17.6 & 21.8 & 15.2 & 13.5 & 14.6 \\
\hline Aldrin & 13.3 & 13.7 & 14.6 & 13.7 & 13.5 \\
\hline Dieldrin & 12.7 & 13.4 & 12.7 & 11.1 & 12.2 \\
\hline Endosulfan I & $1.4 \mathrm{U}$ & $1.3 \mathrm{U}$ & $2.7 \mathrm{U}$ & $2.7 \mathrm{U}$ & $2.5 \mathrm{U}$ \\
\hline Endosulfan II & $1.4 U$ & $1.3 \mathrm{U}$ & $2.7 \mathrm{U}$ & $2.7 \mathrm{U}$ & $2.5 \mathrm{U}$ \\
\hline Endosulfan Sulfate & $1.9 \mathrm{U}$ & $1.8 \mathrm{U}$ & $3.9 \mathrm{U}$ & $3.8 \mathrm{U}$ & $3.6 \mathrm{U}$ \\
\hline Heptachlor & 3.8 & 1.5 & $2.8 \mathrm{U}$ & $2.8 \mathrm{U}$ & $2.6 \mathrm{U}$ \\
\hline Heptachlor Epoxide & $1.0 \mathrm{U}$ & $0.93 \mathrm{U}$ & $2.0 \mathrm{U}$ & $2.0 \mathrm{U}$ & $1.9 \mathrm{U}$ \\
\hline Trans Nonachlor & 4.7 & 6.3 & $2.2 \mathrm{U}$ & $2.2 \mathrm{U}$ & $2.0 \mathrm{U}$ \\
\hline РCB 8 & 38.7 & 33.7 & 23.0 & 19.0 & 18.7 \\
\hline РCB 18 & 71.7 & 65.9 & 49.2 & 41.5 & 42.1 \\
\hline PCB 28 & 60.2 & 54.9 & 65.2 & 60.9 & 57.9 \\
\hline РCB 44 & $0.5 \mathrm{U}$ & $0.5 \mathrm{U}$ & $1.1 \mathrm{U}$ & $1.0 \mathrm{U}$ & $1.0 \mathrm{U}$ \\
\hline PCB 49 & 34.9 & 35.5 & 25.1 & 22.5 & 22.6 \\
\hline РCB 52 & 52.1 & 51.0 & 42.8 & 38.3 & 38.7 \\
\hline РСВ 66 & 34.5 & 34.9 & 31.9 & 27.3 & 28.1 \\
\hline РCB 87 & 6.9 & 7.40 & 5.7 & 3.9 & 4.4 \\
\hline PCB 101 & 29.7 & 30.0 & 24.9 & 21.1 & 22.2 \\
\hline PCB 105 & 6.6 & 6.8 & $2.5 \mathrm{U}$ & $2.5 \mathrm{U}$ & $2.3 \mathrm{U}$ \\
\hline PCB 118 & 18.2 & 18.4 & 14.1 & 11.3 & 11.7 \\
\hline PCB 128 & 1.6 & 1.6 & $1.6 \mathrm{U}$ & $1.5 \mathrm{U}$ & $1.5 U$ \\
\hline PCB 138 & 15.4 & 23.8 & 11.9 & 9.60 & 10.2 \\
\hline PCB 153 & 20.0 & 21.6 & 18.6 & 14.6 & 14.8 \\
\hline PCB 170 & $1.4 \mathrm{U}$ & $1.3 \mathrm{U}$ & $2.7 \mathrm{U}$ & $2.6 \mathrm{U}$ & $2.5 \mathrm{U}$ \\
\hline PCB 180 & 5.2 & 4.9 & $5.7 \mathrm{U}$ & $5.6 \mathrm{U}$ & $5.3 \mathrm{U}$ \\
\hline PCB 183 & $1.4 \mathrm{U}$ & $1.3 \mathrm{U}$ & $2.8 \mathrm{U}$ & $2.7 \mathrm{U}$ & $2.6 \mathrm{U}$ \\
\hline PCB 184 & $1.4 \mathrm{U}$ & $1.3 \mathrm{U}$ & $2.8 \mathrm{U}$ & $2.7 \cup$ & $2.6 U$ \\
\hline PCB 187 & 7.2 & $1.5 U$ & $3.1 \mathrm{U}$ & $3.1 \mathrm{U}$ & $2.9 \mathrm{U}$ \\
\hline PCB 195 & $1.0 \mathrm{U}$ & $0.93 \mathrm{U}$ & $1.9 \mathrm{U}$ & $1.9 \mathrm{U}$ & $1.8 \mathrm{U}$ \\
\hline PCB 206 & $1.6 \mathrm{U}$ & $1.5 \mathrm{U}$ & $3.3 \mathrm{U}$ & $3.2 \mathrm{U}$ & $3.1 \mathrm{U}$ \\
\hline PCB 209 & $1.5 \mathrm{U}$ & $1.4 \mathrm{U}$ & $3.0 \mathrm{U}$ & $2.9 \mathrm{U}$ & $2.8 \mathrm{U}$ \\
\hline
\end{tabular}


Table F.5. (contd)

\begin{tabular}{|c|c|c|c|c|c|}
\hline \multirow{3}{*}{$\begin{array}{l}\text { Sediment Treatment } \\
\text { Replicate }\end{array}$} & \multicolumn{5}{|c|}{ Concentration ( $\mu \mathrm{g} / \mathrm{kg}$ dry wt) } \\
\hline & BX COMP & BX COMP & MDRS $^{(b)}$ & MDRS & MDRS \\
\hline & 4 & 5 & 1 & 2 & 3 \\
\hline \multicolumn{6}{|l|}{ Analytical Replicate } \\
\hline Wet Weight (g) & 13.3 & 10.0 & 20.1 & 15.2 & 10.4 \\
\hline Percent Dry Weight & 15.1 & 13.6 & 11.7 & 14.9 & 11.9 \\
\hline Batch & 1 & 1 & 1 & 2 & 1 \\
\hline 2,4'-DDD & 4.0 & $3.7 \mathrm{U}$ & $2.1 \mathrm{U}$ & $2.2 \mathrm{U}$ & $4.1 \mathrm{U}$ \\
\hline 2,4'-DDE & $2.6 \mathrm{U}$ & $3.8 \mathrm{U}$ & $2.2 \mathrm{U}$ & $2.3 \mathrm{U}$ & $4.2 \mathrm{U}$ \\
\hline 2,4'-DDT & $1.8 \mathrm{U}$ & $2.6 \mathrm{U}$ & $1.5 \mathrm{U}$ & $1.6 \mathrm{U}$ & $2.9 \mathrm{U}$ \\
\hline 4,4'-DDD & 25.6 & 23.6 & 9.45 & $2.3 \mathrm{U}$ & 13.3 \\
\hline 4,4'-DDE & 26.6 & 24.8 & 15.4 & 10.8 & 19.1 \\
\hline 4,4'-DDT & 8.39 & 8.37 & $1.3 \mathrm{U}$ & 6.1 & 7.5 \\
\hline$\alpha$-Chlordane & 18.5 & 13.4 & 0.94 & 0.94 & $1.5 \mathrm{U}$ \\
\hline Aldrin & 14.0 & 13.5 & 7.6 & 8.12 & 11.4 \\
\hline Dieldrin & 12.5 & 12.1 & $4.4 \mathrm{U}$ & $4.6 \mathrm{U}$ & $8.4 \mathrm{U}$ \\
\hline Endosulfan I & $1.8 \mathrm{U}$ & $2.6 \mathrm{U}$ & $1.5 \mathrm{U}$ & $1.6 \mathrm{U}$ & $3.0 \mathrm{U}$ \\
\hline Endosulfan II & $1.8 \mathrm{U}$ & $2.6 \mathrm{U}$ & $1.5 \mathrm{U}$ & $1.6 \mathrm{U}$ & $3.0 \mathrm{U}$ \\
\hline Endosulfan Sulfate & $2.5 \mathrm{U}$ & $3.7 \mathrm{U}$ & $2.1 \mathrm{U}$ & $2.2 \mathrm{U}$ & $4.1 \mathrm{U}$ \\
\hline Heptachlor & $1.8 \mathrm{U}$ & $2.7 \mathrm{U}$ & 2.2 & $1.6 \mathrm{U}$ & 4.5 \\
\hline Heptachlor Epoxide & $1.3 \mathrm{U}$ & $2.0 \mathrm{U}$ & $1.1 \mathrm{U}$ & $1.2 \mathrm{U}$ & $2.1 \mathrm{U}$ \\
\hline Trans Nonachlor & 6.4 & 3.8 & $1.3 \mathrm{U}$ & $1.3 \mathrm{U}$ & $2.4 \mathrm{U}$ \\
\hline PCB 8 & 26.4 & 22.8 & $3.0 \mathrm{U}$ & $3.1 \mathrm{U}$ & $5.7 \mathrm{U}$ \\
\hline РСВ 18 & 59.3 & 40.6 & $0.85 \mathrm{U}$ & $0.87 \mathrm{U}$ & $1.7 \mathrm{U}$ \\
\hline РСВ 28 & 69.9 & 63.1 & 18.4 & 10.1 & 25.6 \\
\hline РСВ 44 & 19.9 & $1.0 \mathrm{U}$ & $0.6 \mathrm{U}$ & $0.6 \mathrm{U}$ & $1.2 \mathrm{U}$ \\
\hline РСВ 49 & 31.6 & 24.7 & 10.7 & 11.5 & 9.03 \\
\hline PCB 52 & 50.1 & 43.0 & 14.1 & 14.2 & 13.2 \\
\hline PCB 66 & 38.7 & 31.8 & 17.1 & 17.5 & $2.4 \mathrm{U}$ \\
\hline РСВ 87 & 8.19 & 5.6 & $2.1 \mathrm{U}$ & $2.2 \mathrm{U}$ & $4.1 \mathrm{U}$ \\
\hline РCB 101 & 31.4 & 26.7 & 11.1 & 10.6 & 10.5 \\
\hline РСB 105 & 4.4 & $2.4 \mathrm{U}$ & $1.4 U$ & 4.8 & $2.7 \mathrm{U}$ \\
\hline PCB 118 & 18.1 & 14.2 & 7.8 & 8.86 & 5.4 \\
\hline РСВ 128 & 1.5 & $1.5 \mathrm{U}$ & $0.94 \mathrm{U}$ & $0.94 U$ & $1.7 \mathrm{U}$ \\
\hline РCB 138 & 14.7 & 12.5 & 5.8 & 5.6 & $4.3 \mathrm{U}$ \\
\hline РCB 153 & 21.8 & 18.7 & 6.7 & 6.4 & $7.1 \mathrm{U}$ \\
\hline PCB 170 & 2.4 & $2.6 \mathrm{U}$ & $1.5 \mathrm{U}$ & $1.5 \mathrm{U}$ & $2.9 \mathrm{U}$ \\
\hline PCB 180 & 7.13 & 5.7 & $3.2 \mathrm{U}$ & $3.4 \mathrm{U}$ & $6.1 \mathrm{U}$ \\
\hline РСВ 183 & $1.8 \mathrm{U}$ & $2.7 \mathrm{U}$ & $1.5 \mathrm{U}$ & $1.6 \mathrm{U}$ & $3.0 \mathrm{U}$ \\
\hline РСВ 184 & $1.8 \mathrm{U}$ & $2.7 \mathrm{U}$ & $1.5 \mathrm{U}$ & $1.6 \mathrm{U}$ & $3.0 \mathrm{U}$ \\
\hline РСВ 187 & $2.0 \mathrm{U}$ & $3.0 \mathrm{U}$ & $1.8 \mathrm{U}$ & $1.8 \mathrm{U}$ & $3.4 \mathrm{U}$ \\
\hline РCB 195 & $1.3 \mathrm{U}$ & $1.8 \mathrm{U}$ & $1.1 \mathrm{U}$ & $1.1 \mathrm{U}$ & $2.0 \mathrm{U}$ \\
\hline PCB 206 & $2.1 \mathrm{U}$ & $3.2 \mathrm{U}$ & $1.8 \mathrm{U}$ & $1.9 \mathrm{U}$ & $3.5 \mathrm{U}$ \\
\hline PCB 209 & $1.9 \mathrm{U}$ & $2.9 \mathrm{U}$ & $1.7 \mathrm{U}$ & $1.7 \mathrm{U}$ & $3.1 \mathrm{U}$ \\
\hline
\end{tabular}


Table F.5. (contd)

\begin{tabular}{|c|c|c|c|c|c|}
\hline \multirow{3}{*}{$\begin{array}{l}\text { Sediment Treatment } \\
\text { Replicate }\end{array}$} & \multicolumn{5}{|c|}{ Concentration ( $\mu \mathrm{g} / \mathrm{kg}$ dry $w t)$} \\
\hline & MDRS & MDRS & Macoma Bkgd. & Macoma Bkgd. & Macoma Bkgd. \\
\hline & 4 & 5 & Tissue & Tissue & Tissue \\
\hline Analytical Replicate & & & 1 & 2 & 3 \\
\hline Wet Weight (g) & 20.7 & 20.2 & 14.3 & 10.2 & 10.5 \\
\hline Percent Dry Weight & 12.2 & 12.7 & 13.7 & 13.7 & 13.7 \\
\hline Batch & 1 & 2 & 2 & 2 & 2 \\
\hline 2,4'-DDD & $2.0 \mathrm{U}$ & $N A^{(c)}$ & $2.5 \mathrm{U}$ & $3.6 \mathrm{U}$ & $3.6 \mathrm{U}$ \\
\hline 2,4'-DDE & $2.0 \mathrm{U}$ & NA & $2.7 \mathrm{U}$ & $3.7 \mathrm{U}$ & $3.6 \mathrm{U}$ \\
\hline 2,4'-DDT & $1.4 \mathrm{U}$ & NA & $1.8 \mathrm{U}$ & $2.5 \mathrm{U}$ & $2.5 \mathrm{U}$ \\
\hline 4,4'-DDD & 9.40 & NA & $2.6 \mathrm{U}$ & $3.7 \mathrm{U}$ & $3.6 \mathrm{U}$ \\
\hline 4,4'-DDE & 16.4 & NA & $1.9 \mathrm{U}$ & $2.7 \mathrm{U}$ & $2.6 \mathrm{U}$ \\
\hline 4,4'-DDT & 4.8 & NA & $1.5 \mathrm{U}$ & $2.2 \mathrm{U}$ & $2.1 \mathrm{U}$ \\
\hline$\alpha$-Chlordane & 1.0 & NA & $0.95 \mathrm{U}$ & $1.4 \mathrm{U}$ & $1.3 \mathrm{U}$ \\
\hline Aldrin & 7.6 & NA & $1.3 \mathrm{U}$ & $1.8 \mathrm{U}$ & $1.7 \mathrm{U}$ \\
\hline Dieldrin & $4.0 \mathrm{U}$ & NA & $5.2 \mathrm{U}$ & $7.35 \mathrm{U}$ & $7.2 \mathrm{U}$ \\
\hline Endosulfan I & $1.4 \mathrm{U}$ & NA & $1.8 \mathrm{U}$ & $2.5 \mathrm{U}$ & $2.5 \mathrm{U}$ \\
\hline Endosulfan II & $1.4 \mathrm{U}$ & NA & $1.8 \mathrm{U}$ & $2.5 \mathrm{U}$ & $2.5 \mathrm{U}$ \\
\hline Endosulfan Sulfate & $2.0 \mathrm{U}$ & NA & $2.5 \mathrm{U}$ & $3.6 \mathrm{U}$ & $3.6 \mathrm{U}$ \\
\hline Heptachlor & $1.5 \mathrm{U}$ & NA & $1.9 \mathrm{U}$ & $2.6 \mathrm{U}$ & $2.6 \mathrm{U}$ \\
\hline Heptachlor Epoxide & $1.1 \mathrm{U}$ & NA & $1.4 \mathrm{U}$ & $1.9 \mathrm{U}$ & $1.8 \mathrm{U}$ \\
\hline Trans Nonachlor & $1.1 \mathrm{U}$ & NA & $1.5 \mathrm{U}$ & $2.0 \mathrm{U}$ & $2.0 \mathrm{U}$ \\
\hline РСВ 8 & $2.8 \mathrm{U}$ & NA & $3.6 \mathrm{U}$ & $5.0 \mathrm{U}$ & $4.9 \mathrm{U}$ \\
\hline РСВ 18 & $0.82 \mathrm{U}$ & NA & $1.0 \mathrm{U}$ & $1.5 \mathrm{U}$ & $1.5 \mathrm{U}$ \\
\hline РСВ 28 & 20.8 & NA & $1.1 \mathrm{U}$ & $1.6 \mathrm{U}$ & $1.5 \mathrm{U}$ \\
\hline РCВ 44 & $0.6 \mathrm{U}$ & NA & $0.73 \mathrm{U}$ & $1.0 \mathrm{U}$ & $1.0 \mathrm{U}$ \\
\hline РCB 49 & 11.0 & NA & $1.9 \mathrm{U}$ & $2.6 \mathrm{U}$ & $2.5 \mathrm{U}$ \\
\hline РCB 52 & 13.1 & NA & $3.3 \mathrm{U}$ & $4.7 \mathrm{U}$ & $4.5 U$ \\
\hline РCB 66 & 18.9 & NA & $1.5 \mathrm{U}$ & $2.2 \mathrm{U}$ & $2.1 \mathrm{U}$ \\
\hline РCB 87 & 2.2 & NA & $2.5 \mathrm{U}$ & $3.6 \mathrm{U}$ & $3.5 \mathrm{U}$ \\
\hline PCB 101 & 13.4 & NA & $1.4 \mathrm{U}$ & $1.9 \mathrm{U}$ & $1.9 \mathrm{U}$ \\
\hline PCB 105 & $1.3 \mathrm{U}$ & NA & $1.7 \mathrm{U}$ & $2.4 \mathrm{U}$ & $2.3 \mathrm{U}$ \\
\hline PCB 118 & 9.16 & NA & $2.0 \mathrm{U}$ & $2.7 U$ & $2.7 \mathrm{U}$ \\
\hline PCB 128 & $0.82 \mathrm{U}$ & NA & $1.1 \mathrm{U}$ & $1.5 \mathrm{U}$ & $1.5 \mathrm{U}$ \\
\hline PCB 138 & 5.8 & NA & $2.7 \mathrm{U}$ & $3.8 \mathrm{U}$ & $3.7 \mathrm{U}$ \\
\hline РCB 153 & 7.9 & NA & $4.4 \mathrm{U}$ & $6.3 \mathrm{U}$ & $6.1 \mathrm{U}$ \\
\hline PCB 170 & 1.4U & NA & $1.8 \mathrm{U}$ & $2.5 \mathrm{U}$ & $2.5 \mathrm{U}$ \\
\hline PCB 180 & $2.9 \mathrm{U}$ & NA & $3.9 \mathrm{U}$ & $5.4 \mathrm{U}$ & $5.2 \mathrm{U}$ \\
\hline PCB 183 & $1.5 \mathrm{U}$ & NA & $1.9 \mathrm{U}$ & $2.6 \mathrm{U}$ & $2.5 \mathrm{U}$ \\
\hline PCB 184 & $1.5 \mathrm{U}$ & NA & $1.9 \mathrm{U}$ & $2.6 \mathrm{U}$ & $2.5 \mathrm{U}$ \\
\hline PCB 187 & $1.6 \mathrm{U}$ & NA & $2.1 \mathrm{U}$ & $2.9 \mathrm{U}$ & $2.9 \mathrm{U}$ \\
\hline PCB 195 & $1.0 \mathrm{U}$ & NA & $1.3 \mathrm{U}$ & $1.8 \mathrm{U}$ & $1.7 \mathrm{U}$ \\
\hline PCB 206 & $1.7 \mathrm{U}$ & NA & $2.2 \mathrm{U}$ & $3.1 \mathrm{U}$ & $3.0 \mathrm{U}$ \\
\hline PCB 209 & $1.6 \mathrm{U}$ & NA & $2.0 \mathrm{U}$ & $2.8 \mathrm{U}$ & $2.7 \mathrm{U}$ \\
\hline
\end{tabular}

(a) U Undetected at or above given concentration.

(b) MDRS Mud Dump Reference Site.

(c) NA Not available; sample dropped during processing. 
Table F.6. Quality Control Data for Pesticide and Polychlorinated Biphenyl (PCB) Analysis of $M$. nasuta Tissue (Wet Weight)

\begin{tabular}{|c|c|c|c|c|c|c|c|}
\hline & & & & & & & \\
\hline & & & Con & centration (p & g/kg wet & wt) & \\
\hline Sediment Treatment & Blank & Blank & $\overline{\mathrm{BX}} \mathrm{COMP}(\mathrm{a})$ & BX COMP & Conc & entration & Percent \\
\hline Replicate & 1 & 1 & 5 & (MS) & Spiked & Recovered & Recovery \\
\hline Analytical Replicate & 1 & 1 & 1 & & & & \\
\hline Wet Weight (g) & 20.0 & & 10.0 & NA & NA & & \\
\hline Percent Dry Weight & NA & NA & 13.6 & NA & NA & & \\
\hline Batch & 1 & 2 & 1 & 1 & & & \\
\hline 2,4'-DDD & $0.25 u^{(b)}$ & $0.32 \mathrm{U}$ & $0.51 U$ & $0.47 \mathrm{U}$ & $N S^{(c)}$ & $N A^{(d)}$ & NA \\
\hline 2,4'-DDE & $0.26 \mathrm{U}$ & $0.33 \mathrm{U}$ & $0.52 \mathrm{U}$ & $0.49 \mathrm{U}$ & NS & NA & NA \\
\hline 2,4'-DDT & $0.18 \mathrm{U}$ & $0.23 \mathrm{U}$ & $0.36 \mathrm{U}$ & $0.33 \mathrm{U}$ & NS & NA & NA \\
\hline 4,4'-DDD & $0.26 \mathrm{U}$ & $0.33 \mathrm{U}$ & 3.22 & 7.48 & 4.65 & 4.26 & 92 \\
\hline $4,4^{\prime}-\mathrm{DDE}$ & $0.19 \mathrm{U}$ & $0.24 U$ & 3.38 & 6.61 & 4.65 & 3.23 & 69 \\
\hline 4,4-DDT & $0.15 U$ & $0.19 \mathrm{U}$ & 1.14 & 5.03 & 4.65 & 3.89 & 84 \\
\hline$\alpha$-Chlordane & $0.10 \mathrm{U}$ & $0.12 \mathrm{U}$ & 1.83 & 5.59 & 4.65 & NA & NA \\
\hline Aldrin & $0.13 \mathrm{U}$ & $0.16 \mathrm{U}$ & 1.84 & 5.43 & 4.65 & 3.59 & 77 \\
\hline Dieldrin & $0.52 \mathrm{U}$ & $0.65 \mathrm{U}$ & 1.65 & 5.22 & 4.65 & 3.57 & 77 \\
\hline Endosulfan I & $0.18 U$ & $0.23 \mathrm{U}$ & $0.36 \mathrm{U}$ & 3.54 & 4.65 & 3.54 & 76 \\
\hline Endosulfan II & $0.18 \mathrm{U}$ & $0.23 U$ & $0.36 \mathrm{U}$ & 4.47 & 4.65 & 4.47 & 96 \\
\hline Endosulfan Sulfate & $0.25 \mathrm{U}$ & $0.32 \mathrm{U}$ & $0.51 \mathrm{U}$ & 4.10 & 4.65 & 4.10 & 88 \\
\hline Heptachlor & $0.19 \mathrm{U}$ & $0.23 \mathrm{U}$ & $0.37 \mathrm{U}$ & 4.03 & 4.65 & 4.03 & 87 \\
\hline Heptachlor Epoxide & $0.13 \mathrm{U}$ & $0.17 \mathrm{U}$ & $0.27 \mathrm{U}$ & 3.50 & 4.65 & 3.50 & 75 \\
\hline Trans Nonachlor & $0.15 \mathrm{U}$ & $0.18 \mathrm{U}$ & $0.29 \mathrm{U}$ & $0.27 \mathrm{U}$ & NS & NA & NA \\
\hline PCB 8 & $0.35 \mathrm{U}$ & $0.44 \mathrm{U}$ & 3.11 & $0.65 \mathrm{U}$ & NS & NA & NA \\
\hline PCB 18 & $0.10 \mathrm{U}$ & 0.22 & 5.53 & $0.19 \mathrm{U}$ & NS & NA & NA \\
\hline PCB 28 & $0.11 \mathrm{U}$ & $0.14 \mathrm{U}$ & 8.59 & 13.5 & 5.92 & 4.92 & 83 \\
\hline PCB 44 & $0.07 \mathrm{U}$ & $0.09 \mathrm{U}$ & $0.14 \mathrm{U}$ & $0.13 \mathrm{U}$ & NS & NA & NA \\
\hline PCB 49 & $0.18 \mathrm{U}$ & $0.23 \mathrm{U}$ & 3.36 & 3.11 & NS & NA & NA \\
\hline PCB 52 & $0.32 U$ & $0.41 \mathrm{U}$ & 5.86 & 17.4 & 12.4 & 11.6 & 93 \\
\hline PCB 66 & $0.15 \mathrm{U}$ & $0.19 \mathrm{U}$ & 4.33 & 3.65 & NS & NA & NA \\
\hline PCB 87 & $0.25 U$ & $0.32 U$ & 0.76 & 0.76 & NS & NA & NA \\
\hline PCB 101 & $0.13 \mathrm{U}$ & $0.17 \mathrm{U}$ & 3.64 & 12.8 & 8.39 & 9.16 & 109 \\
\hline PCB 105 & $0.17 \mathrm{U}$ & $0.21 \mathrm{U}$ & $0.33 \mathrm{U}$ & $0.31 \mathrm{U}$ & NS & NA & NA \\
\hline PCB 118 & $0.19 \mathrm{U}$ & $0.24 \mathrm{U}$ & 1.93 & $0.36 U$ & NS & NA & NA \\
\hline PCB 128 & $0.11 \mathrm{U}$ & $0.13 \mathrm{U}$ & $0.21 \mathrm{U}$ & $0.20 \mathrm{U}$ & NS & NA & NA \\
\hline PCB 138 & $0.27 \mathrm{U}$ & $0.34 \mathrm{U}$ & 1.70 & 5.83 & 3.79 & 4.13 & 109 \\
\hline PCB 153 & $0.44 \mathrm{U}$ & $0.55 \mathrm{U}$ & 2.55 & 8.10 & 4.91 & 5.55 & 113 \\
\hline PCB 170 & $0.18 \mathrm{U}$ & $0.22 \mathrm{U}$ & $0.35 \mathrm{U}$ & $0.33 \mathrm{U}$ & NS & NA & NA \\
\hline PCB 180 & $0.38 \mathrm{U}$ & $0.47 \mathrm{U}$ & 0.77 & $0.70 \mathrm{U}$ & NS & NA & NA \\
\hline PCB 183 & $0.18 \mathrm{U}$ & $0.23 \mathrm{U}$ & $0.37 \mathrm{U}$ & $0.34 \mathrm{U}$ & NS & NA & NA \\
\hline PCB 184 & $0.18 \mathrm{U}$ & $0.23 \mathrm{U}$ & $0.37 \mathrm{U}$ & $0.34 \mathrm{U}$ & NS & NA & NA \\
\hline PCB 187 & $0.21 \mathrm{U}$ & $0.26 \mathrm{U}$ & $0.41 \mathrm{U}$ & $0.38 \mathrm{U}$ & NS & NA & NA \\
\hline РCB 195 & $0.13 \mathrm{U}$ & $0.16 \mathrm{U}$ & $0.25 \mathrm{U}$ & $0.24 \mathrm{U}$ & NS & NA & NA \\
\hline PCB 206 & $0.21 U$ & $0.27 \mathrm{U}$ & $0.43 U$ & $0.40 \mathrm{U}$ & NS & NA & NA \\
\hline PCB 209 & $0.20 \mathrm{U}$ & $0.25 \mathrm{U}$ & $0.39 \mathrm{U}$ & $0.36 \mathrm{U}$ & NS & NA & NA \\
\hline Surrogate Recoveries & & & & & & & \\
\hline PCB 103 (SIS) & 104 & 113 & 84 & 87 & NA & NA & NA \\
\hline PCB 198 (SIS) & 108 & 107 & 82 & 81 & NA & NA & NA \\
\hline
\end{tabular}


Table F.6. (contd)

Matrix Spike Results

\begin{tabular}{|c|c|c|c|c|c|}
\hline \multirow{4}{*}{$\begin{array}{l}\text { Sediment Treatment } \\
\text { Replicate } \\
\text { Analytical Replicate }\end{array}$} & \multicolumn{4}{|c|}{ Concentration $(\mu \mathrm{g} / \mathrm{kg}$ wet $w t)$} & \multirow{7}{*}{$\begin{array}{l}\text { Percent } \\
\text { Recovery }\end{array}$} \\
\hline & \multirow{3}{*}{$\begin{array}{c}\text { MDRS }^{(\theta)} \\
2 \\
1\end{array}$} & \multirow{2}{*}{$\begin{array}{c}\text { MDRS } \\
\text { (MS) }\end{array}$} & \multicolumn{2}{|c|}{ Concentration } & \\
\hline & & & Spiked & Recovered & \\
\hline & & & & & \\
\hline Wet Weight (g) & 15.2 & NA & \multicolumn{2}{|c|}{ NA } & \\
\hline Percent Dry Weight & 14.9 & NA & \multirow{2}{*}{\multicolumn{2}{|c|}{ NA }} & \\
\hline Batch & 2 & 2 & & & \\
\hline 2,4'-DDD & $0.33 \mathrm{U}$ & $0.30 \mathrm{U}$ & NS & NA & NA \\
\hline 2,4'-DDE & $0.34 \mathrm{U}$ & $0.31 \mathrm{U}$ & NS & NA & NA \\
\hline $2,4^{\prime}-\mathrm{DDT}$ & $0.24 \mathrm{U}$ & $0.21 \mathrm{U}$ & NS & NA & NA \\
\hline $4,4^{\prime}-\mathrm{DDD}$ & $0.34 \mathrm{U}$ & 3.84 & 3.00 & 3.84 & $128^{(f)}$ \\
\hline $4,4^{\prime}-$ DDE & 1.61 & 4.38 & 3.00 & 2.77 & 92 \\
\hline 4,4'-DDT & 0.91 & 2.84 & 3.00 & 1.93 & 64 \\
\hline$\alpha$-Chlordane & 0.14 & 2.57 & 3.00 & 2.43 & 81 \\
\hline Aldrin & 1.21 & 3.49 & 3.00 & 2.28 & 76 \\
\hline Dieldrin & $0.68 \mathrm{U}$ & 3.06 & 3.00 & 3.06 & 102 \\
\hline Endosulfan I & $0.24 \mathrm{U}$ & 2.37 & 3.00 & 2.37 & 79 \\
\hline Endosulfan II & $0.24 \mathrm{U}$ & 2.31 & 3.00 & 2.31 & 77 \\
\hline Endosulfan Sulfate & $0.33 \mathrm{U}$ & 2.52 & 3.00 & 2.52 & 84 \\
\hline Heptachlor & $0.24 \mathrm{U}$ & 3.02 & 3.00 & 3.02 & 101 \\
\hline Heptachlor Epoxide & $0.18 \mathrm{U}$ & 2.82 & 3.00 & 2.82 & 94 \\
\hline Trans Nonachlor & $0.19 \mathrm{U}$ & $0.17 \mathrm{U}$ & NS & NA & NA \\
\hline PCB 8 & $0.46 \mathrm{U}$ & $0.42 U$ & NS & NA & NA \\
\hline PCB 18 & $0.13 U$ & $0.12 U$ & NS & NA & NA \\
\hline PCB 28 & $0.15 \mathrm{U}$ & 5.61 & 3.83 & 5.61 & $146^{(f)}$ \\
\hline PCB 44 & $0.09 \mathrm{U}$ & $0.08 \mathrm{U}$ & NS & NA & NA \\
\hline PCB 49 & 1.72 & 1.58 & NS & NA & NA \\
\hline PCB 52 & 2.12 & 10.1 & 7.98 & 8.00 & 100 \\
\hline PCB 66 & 2.61 & 2.47 & NS & NA & NA \\
\hline PCB 87 & $0.33 \mathrm{U}$ & $0.30 \mathrm{U}$ & NS & NA & NA \\
\hline PCB 101 & 1.58 & 7.46 & 5.42 & 5.88 & 108 \\
\hline PCB 105 & 0.71 & $0.20 \mathrm{U}$ & NS & NA & NA \\
\hline PCB 118 & 1.32 & 1.15 & NS & NA & NA \\
\hline PCB 128 & $0.14 \mathrm{U}$ & $0.13 \mathrm{U}$ & NS & NA & NA \\
\hline PCB 138 & 0.83 & 3.30 & 2.44 & 2.47 & 101 \\
\hline PCB 153 & 0.95 & 4.13 & 3.17 & 3.18 & 100 \\
\hline PCB 170 & $0.23 \mathrm{U}$ & $0.21 \mathrm{U}$ & NS & NA & NA \\
\hline PCB 180 & $0.50 \mathrm{U}$ & $0.45 \mathrm{U}$ & NS & NA & NA \\
\hline PCB 183 & $0.24 \mathrm{U}$ & $0.22 U$ & NS & NA & NA \\
\hline PCB 184 & $0.24 \mathrm{U}$ & $0.22 \mathrm{U}$ & NS & NA & NA \\
\hline PCB 187 & $0.27 \mathrm{U}$ & $0.25 \mathrm{U}$ & NS & NA & NA \\
\hline PCB 195 & $0.17 \mathrm{U}$ & $0.15 \mathrm{U}$ & NS & NA & NA \\
\hline PCB 206 & $0.28 \mathrm{U}$ & $0.26 U$ & NS & NA & NA \\
\hline PCB 209 & $0.26 \mathrm{U}$ & $0.23 \mathrm{U}$ & NS & NA & NA \\
\hline \multicolumn{6}{|c|}{ Surrogate Recoveries (\%) } \\
\hline PCB 103 (SIS) & 89 & 97 & NA & NA & NA \\
\hline PCB 198 (SIS) & 73 & 85 & NA & NA & NA \\
\hline
\end{tabular}


Table F.6. (contd)

Analytical Replicates

\begin{tabular}{|c|c|c|c|c|}
\hline \multirow{3}{*}{$\begin{array}{l}\text { Sediment Treatment } \\
\text { Replicate }\end{array}$} & \multicolumn{3}{|c|}{ Concentration ( $\mu \mathrm{g} / \mathrm{kg}$ wet $w t)$} & \multirow{3}{*}{$\begin{array}{l}\text { RSD } \\
(\%)\end{array}$} \\
\hline & BX COMP(a) & BX COMP & BX COMP & \\
\hline & 3 & 3 & 3 & \\
\hline Analytical Replicate & 1 & 2 & 3 & \\
\hline Wet Weight (g) & 9.57 & 9.79 & 10.3 & \\
\hline Percent Dry Weight & 86.3 & NA & NA & \\
\hline Batch & 1 & 1 & 1 & \\
\hline 2,4'-DDD & $0.53 \mathrm{U}$ & $0.52 \mathrm{U}$ & $0.49 \mathrm{U}$ & NA \\
\hline $2,4^{\prime}-\mathrm{DDE}$ & $0.54 \mathrm{U}$ & $0.53 \mathrm{U}$ & $0.51 \mathrm{U}$ & NA \\
\hline 2,4'-DDT & $0.37 \mathrm{U}$ & $0.37 \mathrm{U}$ & $0.35 \mathrm{U}$ & NA \\
\hline 4,4'-DDD & 3.11 & 2.77 & 2.82 & 6 \\
\hline 4,4'-DDE & 3.57 & 3.12 & 3.13 & 8 \\
\hline 4,4'-DDT & 1.36 & 0.94 & 0.94 & 22 \\
\hline$\alpha$-Chlordane & 2.09 & 1.85 & 2.01 & 6 \\
\hline Aldrin & 2.01 & 1.88 & 1.86 & 4 \\
\hline Dieldrin & 1.74 & 1.53 & 1.68 & 7 \\
\hline Endosulfan 1 & $0.37 \mathrm{U}$ & $0.37 \mathrm{U}$ & $0.35 \mathrm{U}$ & NA \\
\hline Endosulfan II & $0.37 \mathrm{U}$ & $0.37 \mathrm{U}$ & $0.35 \mathrm{U}$ & NA \\
\hline Endosulfan Sulfate & $0.53 U$ & $0.52 \mathrm{U}$ & $0.49 \mathrm{U}$ & NA \\
\hline Heptachlor & $0.38 \mathrm{U}$ & $0.38 \mathrm{U}$ & $0.36 \mathrm{U}$ & NA \\
\hline Heptachlor Epoxide & $0.28 \mathrm{U}$ & $0.27 \mathrm{U}$ & $0.26 \mathrm{U}$ & NA \\
\hline Trans Nonachlor & $0.30 \mathrm{U}$ & $0.30 \mathrm{U}$ & $0.28 \mathrm{U}$ & NA \\
\hline PCB 8 & 3.16 & 2.61 & 2.57 & 12 \\
\hline PCB 18 & 6.77 & 5.71 & 5.79 & 10 \\
\hline PCB 28 & 8.97 & 8.38 & 7.96 & 6 \\
\hline PCB 44 & $0.15 \mathrm{U}$ & $0.14 U$ & $0.14 U$ & NA \\
\hline PCB 49 & 3.45 & 3.10 & 3.11 & 6 \\
\hline PCB 52 & 5.89 & 5.27 & 5.32 & 6 \\
\hline PCB 66 & 4.39 & 3.75 & 3.86 & 9 \\
\hline PCB 87 & 0.79 & 0.53 & 0.60 & 21 \\
\hline PCB 101 & 3.43 & 2.90 & 3.05 & 9 \\
\hline PCB 105 & $0.35 \mathrm{U}$ & $0.34 \mathrm{U}$ & $0.32 \mathrm{U}$ & NA \\
\hline PCB 118 & 1.94 & 1.56 & 1.61 & 12 \\
\hline PCB 128 & $0.22 \mathrm{U}$ & $0.21 \mathrm{U}$ & $0.20 \mathrm{U}$ & NA \\
\hline PCB 138 & 1.64 & 1.32 & 1.40 & 11 \\
\hline PCB 153 & 2.56 & 2.01 & 2.03 & 14 \\
\hline PCB 170 & $0.37 \mathrm{U}$ & $0.36 \mathrm{U}$ & $0.34 \mathrm{U}$ & NA \\
\hline PCB 180 & $0.78 \mathrm{U}$ & $0.77 \mathrm{U}$ & $0.73 \mathrm{U}$ & NA \\
\hline PCB 183 & $0.38 \mathrm{U}$ & $0.37 \mathrm{U}$ & $0.36 U$ & NA \\
\hline PCB 184 & $0.38 U$ & $0.37 \mathrm{U}$ & $0.36 \mathrm{U}$ & NA \\
\hline PCB 187 & $0.43 \mathrm{U}$ & $0.42 U$ & $0.40 \mathrm{U}$ & NA \\
\hline PCB 195 & $0.26 U$ & $0.26 \mathrm{U}$ & $0.25 \mathrm{U}$ & NA \\
\hline PCB 206 & $0.45 \mathrm{U}$ & $0.44 \mathrm{U}$ & $0.42 \mathrm{U}$ & NA \\
\hline PCB 209 & $0.41 \mathrm{U}$ & $0.40 \mathrm{U}$ & $0.38 \mathrm{U}$ & NA \\
\hline \multicolumn{5}{|c|}{ Surrogate Recoveries (\%) } \\
\hline PCB 103 (SIS) & 80 & 82 & 83 & NA \\
\hline PCB 198 (SIS) & 74 & 73 & 76 & NA \\
\hline
\end{tabular}


Table F.6. (contd)

\begin{tabular}{|c|c|c|c|c|}
\hline \multirow{3}{*}{$\begin{array}{l}\text { Sediment Treatment } \\
\text { Replicate }\end{array}$} & \multicolumn{4}{|c|}{ Analytical Replicates } \\
\hline & \multicolumn{3}{|c|}{ Concentration $(\mu \mathrm{g} / \mathrm{kg}$ wet $w \mathrm{t})$} & \multirow{6}{*}{$\begin{array}{c}\text { RSD } \\
(\%)\end{array}$} \\
\hline & Macoma Bkgd. & Macoma Bkgd. & Macoma Bkgd. & \\
\hline Analytical Replicate & 1 & 2 & 3 & \\
\hline Wet Weight (g) & 14.3 & 10.2 & 10.5 & \\
\hline Percent Dry Weight & 14.0 & 13.8 & 13.4 & \\
\hline Batch & 2 & 2 & 2 & \\
\hline 2,4'-DDD & $0.35 U$ & $0.50 \mathrm{U}$ & $0.49 \mathrm{U}$ & NA \\
\hline $2,4^{\prime}-\mathrm{DDE}$ & $0.37 \mathrm{U}$ & $0.51 \mathrm{U}$ & $0.50 \mathrm{U}$ & NA \\
\hline $2,4^{\prime}-\mathrm{DDT}$ & $0.25 \mathrm{U}$ & $0.35 \mathrm{U}$ & $0.34 \mathrm{U}$ & NA \\
\hline $4,4^{\prime}-\mathrm{DDD}$ & $0.36 \mathrm{U}$ & $0.51 \mathrm{U}$ & $0.50 \mathrm{U}$ & NA \\
\hline 4,4'-DDE & $0.26 \mathrm{U}$ & $0.37 \mathrm{U}$ & $0.36 \mathrm{U}$ & NA \\
\hline 4,4'-DDT & 1.07 & $0.30 \mathrm{U}$ & $0.29 \mathrm{U}$ & NA \\
\hline$\alpha$-Chlordane & $0.13 U$ & $0.19 \mathrm{U}$ & $0.18 U$ & NA \\
\hline Aldrin & $0.18 U$ & $0.25 \mathrm{U}$ & $0.24 \mathrm{U}$ & NA \\
\hline Dieldrin & $0.72 U$ & $1.01 \mathrm{U}$ & $0.99 \mathrm{U}$ & NA \\
\hline Endosulfan I & $0.25 \mathrm{U}$ & $0.35 \mathrm{U}$ & $0.35 \mathrm{U}$ & NA \\
\hline Endosulfan II & $0.25 U$ & $0.35 \mathrm{U}$ & $0.35 \mathrm{U}$ & NA \\
\hline Endosulfan Sulfate & $0.35 \mathrm{U}$ & $0.50 \mathrm{U}$ & $0.49 \mathrm{U}$ & NA \\
\hline Heptachlor & $0.26 \mathrm{U}$ & $0.36 \mathrm{U}$ & $0.36 \mathrm{U}$ & NA \\
\hline Heptachlor Epoxide & $0.19 \mathrm{U}$ & $0.26 U$ & $0.25 U$ & NA \\
\hline Trans Nonachlor & $0.20 \mathrm{U}$ & $0.28 U$ & $0.28 \mathrm{U}$ & NA \\
\hline PCB 8 & $0.49 \cup$ & $0.69 \mathrm{U}$ & $0.68 \mathrm{U}$ & NA \\
\hline PCB 18 & $0.14 \mathrm{U}$ & $0.20 \mathrm{U}$ & $0.20 \mathrm{U}$ & NA \\
\hline PCB 28 & $0.15 U$ & $0.22 \mathrm{U}$ & $0.21 \mathrm{U}$ & NA \\
\hline PCB 44 & $0.10 U$ & $0.14 \mathrm{U}$ & $0.14 \mathrm{U}$ & NA \\
\hline PCB 49 & $0.26 \mathrm{U}$ & $0.36 \mathrm{U}$ & $0.35 U$ & NA \\
\hline PCB 52 & $0.45 \mathrm{U}$ & $0.64 \mathrm{U}$ & $0.62 \mathrm{U}$ & NA \\
\hline PCB 66 & $0.21 \mathrm{U}$ & $0.30 \mathrm{U}$ & $0.29 \mathrm{U}$ & NA \\
\hline PCB 87 & $0.35 \mathrm{U}$ & $0.49 \mathrm{U}$ & $0.48 \mathrm{U}$ & NA \\
\hline PCB 101 & $0.19 \mathrm{U}$ & $0.26 \mathrm{U}$ & $0.26 \mathrm{U}$ & NA \\
\hline PCB 105 & $0.23 \mathrm{U}$ & $0.33 \mathrm{U}$ & $0.32 \mathrm{U}$ & NA \\
\hline PCB 118 & $0.27 \mathrm{U}$ & $0.37 \mathrm{U}$ & $0.37 \mathrm{U}$ & NA \\
\hline PCB 128 & $0.15 \mathrm{U}$ & $0.21 \mathrm{U}$ & $0.20 \mathrm{U}$ & NA \\
\hline PCB 138 & $0.37 \mathrm{U}$ & $0.52 \mathrm{U}$ & $0.51 \mathrm{U}$ & NA \\
\hline PCB 153 & $0.61 \mathrm{U}$ & $0.86 U$ & $0.84 \mathrm{U}$ & NA \\
\hline PCB 170 & $0.25 \mathrm{U}$ & $0.34 \mathrm{U}$ & $0.34 \mathrm{U}$ & NA \\
\hline PCB 180 & $0.53 \mathrm{U}$ & $0.74 \mathrm{U}$ & $0.72 \mathrm{U}$ & NA \\
\hline PCB 183 & $0.26 \mathrm{U}$ & $0.36 \mathrm{U}$ & $0.35 \mathrm{U}$ & NA \\
\hline PCB 184 & $0.26 \mathrm{U}$ & $0.36 \mathrm{U}$ & $0.35 U$ & NA \\
\hline PCB 187 & $0.29 \mathrm{U}$ & $0.40 \mathrm{U}$ & $0.40 \mathrm{U}$ & NA \\
\hline PCB 195 & $0.18 U$ & $0.25 \mathrm{U}$ & $0.24 \mathrm{U}$ & NA \\
\hline PCB 206 & $0.30 \mathrm{U}$ & $0.42 \mathrm{U}$ & $0.41 \mathrm{U}$ & NA \\
\hline PCB 209 & $0.27 U$ & $0.38 \mathrm{U}$ & $0.37 U$ & NA \\
\hline \multicolumn{5}{|c|}{ Surrogate Recoveries (\%) } \\
\hline PCB 103 (SIS) & 105 & 103 & 104 & NA \\
\hline PCB 198 (SIS) & 94 & 84 & 88 & NA \\
\hline
\end{tabular}

(a) Sample randomly selected for use as a quality control sample in analytical batch.

(b) $U$ Undetected at or above given concentration.

(c) NS Not spiked.

(d) NA Not applicable.

(e) MDRS Mud Dump Reference Site.

(f) Outside quality control criteria $(50-120 \%)$ for spike recovery. 
Table F.7. Polynuclear Aromatic Hydrocarbons (PAHs) in M. nasuta Tissue (Wet Weight), Bronx River

\begin{tabular}{|c|c|c|c|c|c|}
\hline \multirow[b]{2}{*}{ Sediment Treatment } & \multicolumn{5}{|c|}{ Concentration $(\mu g / k g$ wet wt) } \\
\hline & BX COMP & BX COMP & $\mathrm{BX}$ COMP & BX COMP & BX COMP \\
\hline Replicate & 1 & 2 & 3 & 3 & 3 \\
\hline Analytical Replicate & & & 1 & 2 & 3 \\
\hline Wet Weight (g) & 20.2 & 20.1 & 9.6 & 9.8 & 10.3 \\
\hline Percent Dry Weight & 13.3 & 14.1 & 13.8 & NA & NA \\
\hline Batch & 2 & 2 & 1 & 1 & 1 \\
\hline 1,4-Dichlorobenzene ${ }^{(a)}$ & $1.86 \mathrm{U}^{(\mathrm{b})}$ & $1.86 \mathrm{U}$ & $4.18 \mathrm{U}$ & $4.09 \mathrm{U}$ & $3.88 \mathrm{U}$ \\
\hline Naphthalene & $3.64^{(c)}$ & 4.11 & 6.46 & 5.85 & 6.13 \\
\hline Acenaphthylene & $2.69^{(c)}$ & $2.45^{\text {(c) }}$ & 1.65 & $1.12 U$ & $1.07 \mathrm{U}$ \\
\hline Acenaphthene & 8.18 & 5.65 & 4.63 & 3.24 & 2.90 \\
\hline Fluorene & 8.73 & 6.56 & 4.78 & 4.35 & 3.70 \\
\hline Phenanthrene & 53.9 & 41.0 & 40.5 & 33.9 & 36.5 \\
\hline Anthracene & 27.5 & 25.1 & 24.0 & 19.3 & 19.9 \\
\hline Fluoranthene & 269 & 256 & 233 & 182 & 191 \\
\hline Pyrene & 330 & 309 & 312 & 265 & 263 \\
\hline Benzo[a]anthracene & 114 & 122 & 118 & 99.9 & 103 \\
\hline Chrysene & 144 & 150 & 113 & 92.2 & 97.6 \\
\hline Benzo[b]fluoranthene & 92.2 & 102 & 128 & 97.1 & 101 \\
\hline Benzo[k]fluoranthene & 25.5 & 28.4 & 15.8 & 12.1 & 12.3 \\
\hline Benzo[a]pyrene & 57.5 & 65.7 & 61.4 & 47.3 & 49.2 \\
\hline Indeno[123-cd]pyrene & 10.9 & 13.8 & 9.92 & $7.25 \mathrm{~B}^{(\mathrm{d})}$ & 8.11 \\
\hline Dibenzo[a,h]anthracene & 3.37 & 4.22 & $3.16 \mathrm{~B}$ & $2.49 \mathrm{U}$ & $2.53 \mathrm{~B}$ \\
\hline Benzo[g,h,i]perylene & 13.6 & 16.3 & 10.6 & 7.40 & 8.44 \\
\hline \multicolumn{6}{|l|}{ Surrogate Recoveries (\%) } \\
\hline d4 1,4-Dichlorobenzene & $20^{(\mathrm{e})}$ & $29^{(e)}$ & 48 & 41 & 45 \\
\hline d8 Naphthalene & $27^{(\mathrm{e})}$ & 37 & 53 & 47 & 50 \\
\hline d10 Acenaphthene & 34 & 44 & 49 & 50 & 57 \\
\hline d12 Chrysene & 34 & 47 & 52 & 48 & 51 \\
\hline d14 Dibenzo[a,h]anthracene & 42 & 58 & 33 & 31 & 31 \\
\hline
\end{tabular}


Table F.7. (contd)

\begin{tabular}{|c|c|c|c|c|c|}
\hline \multirow[b]{2}{*}{ Sediment Treatment } & \multicolumn{5}{|c|}{ Concentration ( $\mu \mathrm{g} / \mathrm{kg}$ wet $w t)$} \\
\hline & BX COMP & BX COMP & MDRS $^{(f)}$ & MDRS & MDRS \\
\hline Replicate & 4 & 5 & 1 & 2 & 3 \\
\hline \multicolumn{6}{|l|}{ Analytical Replicate } \\
\hline Wet Weight (g) & 13.3 & 9.97 & 20.1 & 15.2 & 10.4 \\
\hline Percent Dry Weight & 15.1 & 13.6 & 11.7 & 14.9 & 11.9 \\
\hline Batch & 1 & 1 & 1 & 2 & 1 \\
\hline 1,4-Dichlorobenzene & $3.01 \mathrm{U}$ & 4.01 & $1.99 \mathrm{U}$ & $2.46 \mathrm{U}$ & $3.85 \mathrm{U}$ \\
\hline Naphthalene & 6.29 & $4.91 \mathrm{U}$ & 2.22 & 2.62 & 5.96 \\
\hline Acenaphthylene & 2.23 & 1.10 & $0.55 \mathrm{U}$ & $1.16^{(c)}$ & $1.06 \mathrm{U}$ \\
\hline Acenaphthene & 5.08 & $2.79 \mathrm{U}$ & $1.38 \mathrm{U}$ & $1.72 \mathrm{U}$ & $2.68 \mathrm{U}$ \\
\hline Fluorene & 3.62 & $2.75 \mathrm{U}$ & $1.27 \mathrm{U}$ & 2.04 & $2.46 \mathrm{U}$ \\
\hline Phenanthrene & 46.2 & 32.7 & $2.66 \mathrm{U}$ & $3.38 \mathrm{U}$ & $5.14 \mathrm{U}$ \\
\hline Anthracene & 25.9 & 17.5 & $2.24 \mathrm{U}$ & $3.07^{(c)}$ & $4.33 \mathrm{U}$ \\
\hline Fluoranthene & 241 & 184 & 8.44 & 10.5 & 9.18 \\
\hline Pyrene & 302 & 226 & 24.4 & 23.5 & 25.2 \\
\hline Benzo[a]anthracene & 131 & 104 & 7.50 & 10.0 & 8.03 \\
\hline Chrysene & 135 & 103 & 5.25 & 6.97 & 6.25 \\
\hline Benzo[b]fluoranthene & 138 & 107 & 14.6 & 15.1 & 16.7 \\
\hline Benzo[k]fluoranthene & 17.9 & 13.1 & 2.31 & 6.12 & $2.89 \mathrm{U}$ \\
\hline Benzo[a]pyrene & 71.3 & 52.9 & 6.32 & 8.53 & 7.51 \\
\hline Indeno[123-cd]pyrene & 13.7 & 8.60 & $1.94 \mathrm{~B}$ & $2.33 \mathrm{U}$ & $2.95 \mathrm{U}$ \\
\hline Dibenzo[a,h]anthracene & $3.42 \mathrm{~B}$ & $2.45 \mathrm{~B}$ & $1.21 \mathrm{U}$ & $1.66 U$ & $2.35 \mathrm{U}$ \\
\hline Benzo[g,h,i]perylene & 14.7 & $8.64 \mathrm{U}$ & $1.91 \mathrm{~B}$ & 3.47 & $2.06 \mathrm{U}$ \\
\hline \multicolumn{6}{|l|}{ Surrogate Recoveries (\%) } \\
\hline d4 1,4-Dichlorobenzene & 48 & 40 & 49 & 48 & 39 \\
\hline d8 Naphthalene & 55 & 48 & 55 & 59 & 44 \\
\hline d10 Acenaphthene & 66 & 63 & 67 & 69 & 62 \\
\hline d12 Chrysene & 72 & 62 & 52 & 68 & 41 \\
\hline d14 Dibenzo[a,h]anthracene & 71 & 49 & 36 & 85 & $16^{(\mathrm{e})}$ \\
\hline
\end{tabular}


Table F.7. (contd)

Concentration ( $\mu \mathrm{g} / \mathrm{kg}$ wet $\mathrm{wt})$

\begin{tabular}{lccccc}
\cline { 2 - 6 } Sediment Treatment & MDRS & MDRS & Macoma Bkgd. & Macoma Bkgd. & Macoma Bkgd. \\
Replicate & 4 & 5 & Tissue & Tissue & Tissue \\
Analytical Replicate & & & 1 & 2 & 3 \\
Wet Weight (g) & 20.7 & 20.2 & 14.3 & 10.2 & 10.5 \\
Percent Dry Weight & 12.2 & 12.7 & 13.7 & 13.7 & 13.7 \\
Batch & 1 & 2 & 2 & 2 & 2 \\
\hline & & & & & \\
1,4-Dichlorobenzene & $1.94 \mathrm{U}$ & NA (g) & $2.61 \mathrm{U}$ & $3.65 \mathrm{U}$ & $3.58 \mathrm{U}$ \\
Naphthalene & 2.99 & NA & 2.64 (c) & $3.65 \mathrm{U}$ & $3.58 \mathrm{U}$ \\
Acenaphthylene & $0.53 \mathrm{U}$ & NA & $1.02 \mathrm{U}$ & $1.42 \mathrm{U}$ & $1.39 \mathrm{U}$ \\
Acenaphthene & $1.34 \mathrm{U}$ & NA & $1.83 \mathrm{U}$ & $2.56 \mathrm{U}$ & $2.50 \mathrm{U}$ \\
Fluorene & $1.24 \mathrm{U}$ & NA & $1.73 \mathrm{U}$ & $2.42 \mathrm{U}$ & $2.37 \mathrm{U}$ \\
Phenanthrene & 2.79 & NA & $3.58 \mathrm{U}$ & $5.02 \mathrm{U}$ & $4.91 \mathrm{U}$ \\
Anthracene & $2.18 \mathrm{U}$ & NA & $3.13 \mathrm{U}$ & $4.39 \mathrm{U}$ & $4.30 \mathrm{U}$ \\
Fluoranthene & 8.31 & NA & $7.51 \mathrm{U}$ & $10.5 \mathrm{U}$ & $10.3 \mathrm{U}$ \\
Pyrene & 21.3 & NA & $6.40 \mathrm{U}$ & $8.95 \mathrm{U}$ & $8.77 \mathrm{U}$ \\
Benzo[a]anthracene & 8.40 & NA & $2.52 \mathrm{~B}$ & $3.06 \mathrm{~B}$ & 3.11 \\
Chrysene & 6.43 & NA & $3.18 \mathrm{U}$ & $4.45 \mathrm{U}$ & $4.35 \mathrm{U}$ \\
Benzo[b]fluoranthene & 16.5 & NA & $2.30 \mathrm{U}$ & $3.22 \mathrm{U}$ & $3.15 \mathrm{U}$ \\
Benzo[k]fluoranthene & 2.40 & NA & $2.34 \mathrm{U}$ & $3.27 \mathrm{U}$ & $3.21 \mathrm{U}$ \\
Benzo[a]pyrene & 7.35 & NA & $2.09 \mathrm{U}$ & $2.93 \mathrm{U}$ & $2.87 \mathrm{U}$ \\
Indeno[123-cd]pyrene & $1.75 \mathrm{~B}$ & NA & $2.47 \mathrm{U}$ & $3.45 \mathrm{U}$ & $3.38 \mathrm{U}$ \\
Dibenzo[a,h]anthracene & $1.18 \mathrm{U}$ & NA & $1.76 \mathrm{U}$ & $2.47 \mathrm{U}$ & $2.42 \mathrm{U}$ \\
Benzo[g,h,i]perylene & $1.81 \mathrm{~B}$ & NA & $1.96 \mathrm{U}$ & $2.75 \mathrm{U}$ & $2.69 \mathrm{U}$ \\
& & & & & \\
Surrogate Recoveries (\%) & & & & & \\
d4 1,4-Dichlorobenzene & 42 & NA & 42 & 63 & 48 \\
d8 Naphthalene & 48 & NA & 52 & 73 & 61 \\
d10 Acenaphthene & 61 & NA & 67 & 80 & 71 \\
d12 Chrysene & 55 & NA & 87 & 79 & 82 \\
d14 Dibenzo[a,h]anthracene & 35 & NA & 108 & 96 & 101 \\
& & & & &
\end{tabular}

(a) Target detection limits are $4.0 \mu \mathrm{g} / \mathrm{kg}$ for all analytes (except 1,4-Dichlorobenzene which is $0.4 \mu \mathrm{g} / \mathrm{kg}$ ).

(b) $U$ Undetected at or above given concentration.

(c) Ion ratio out or confirmation ion not detected.

(d) B Analyte detected in sample is $<5$ times blank value.

(e) Outside quality control criteria $(30-105 \%)$ for surrogate recovery.

(f) MDRS Mud Dump Reference Site.

(g) NA Not available; sample dropped during processing. 
Table F.8. Polynuclear Aromatic Hydrocarbons (PAHs) in M. nasuta Tissue (Dry Weight), Bronx River

\begin{tabular}{|c|c|c|c|c|c|}
\hline \multirow[b]{2}{*}{ Sediment Treatment } & \multicolumn{5}{|c|}{ Concentration $(\mu \mathrm{g} / \mathrm{kg}$ dry $w t)$} \\
\hline & $\mathrm{BX}$ COMP & BX COMP & BX COMP & BX COMP & BX COMP \\
\hline Replicate & 1 & 2 & 3 & 3 & 3 \\
\hline Analytical Replicate & & & 1 & 2 & 3 \\
\hline Wet Weight (g) & 20.2 & 20.1 & 9.6 & 9.8 & 10.3 \\
\hline Percent Dry Weight & 13.3 & 14.1 & 13.8 & NA & NA \\
\hline Batch & 2 & 2 & 1 & 1 & 1 \\
\hline 1,4-Dichlorobenzene & $14.0 U^{(a)}$ & $13.2 U$ & $30.4 \mathrm{U}$ & $29.7 U$ & $28.2 U$ \\
\hline Naphthalene & $27.4^{\text {(b) }}$ & 29.3 & 47.0 & 42.5 & 44.6 \\
\hline Acenaphthylene & $20.3^{(b)}$ & $17.4^{\text {(b) }}$ & 12.0 & $8.1 \mathrm{U}$ & $7.8 \mathrm{U}$ \\
\hline Acenaphthene & 61.6 & 40.2 & 33.7 & 23.6 & 21.1 \\
\hline Fluorene & 65.7 & 46.7 & 34.8 & 31.6 & 26.9 \\
\hline Phenanthrene & 406 & 292 & 295 & 247 & 265 \\
\hline Anthracene & 207 & 179 & 174 & 140 & 145 \\
\hline Fluoranthene & 2030 & 1820 & 1690 & 1320 & 1390 \\
\hline Pyrene & 2480 & 2200 & 2270 & 1930 & 1910 \\
\hline Benzo[a]anthracene & 858 & 868 & 857 & 727 & 749 \\
\hline Chrysene & 1080 & 1070 & 821 & 671 & 710 \\
\hline Benzo[b]fluoranthene & 694 & 726 & 928 & 706 & 735 \\
\hline Benzo[k]fluoranthene & 192 & 202 & 115 & 88.0 & 89.5 \\
\hline Benzo[a]pyrene & 433 & 468 & 446 & 344 & 358 \\
\hline Indeno[123-cd]pyrene & 82.1 & 98.2 & 72.2 & $52.7 \mathrm{~B}^{(\mathrm{c})}$ & 59.0 \\
\hline Dibenzo[a,h]anthracene & 25.4 & 30.0 & $23.0 \mathrm{~B}$ & $18.1 \mathrm{U}$ & $18.4 \mathrm{~B}$ \\
\hline Benzo[g,h,i]perylene & 102 & 116 & 77.4 & 53.8 & 61.4 \\
\hline
\end{tabular}


Table F.8. (contd)

\begin{tabular}{lccccc} 
& \multicolumn{5}{c}{ Concentration $(\mu \mathrm{g} / \mathrm{kg}$ dry wt) } \\
\cline { 2 - 6 } Sediment Treatment & $\mathrm{BX}$ COMP & BX COMP & MDRS (d) & MDRS & MDRS \\
Replicate & 4 & 5 & 1 & 2 & 3 \\
Analytical Replicate & & & & & \\
Wet Weight (g) & 13.3 & 9.97 & 20.1 & 15.2 & 10.4 \\
Percent Dry Weight & 15.1 & 13.6 & 11.7 & 14.9 & 11.9 \\
Batch & 1 & 1 & 1 & 2 & 1 \\
\hline & & & & & \\
1,4-Dichlorobenzene & $19.9 \mathrm{U}$ & 29.5 & $17.0 \mathrm{U}$ & $16.5 \mathrm{U}$ & $32.5 \mathrm{U}$ \\
Naphthalene & 41.5 & $36.1 \mathrm{U}$ & 18.9 & 17.6 & 50.3 \\
Acenaphthylene & 14.7 & 8.09 & $4.7 \mathrm{U}$ & 7.79 (b) & $8.95 \mathrm{U}$ \\
Acenaphthene & 33.6 & $20.5 \mathrm{U}$ & $11.8 \mathrm{U}$ & $11.5 \mathrm{U}$ & $22.6 \mathrm{U}$ \\
Fluorene & 23.9 & $20.2 \mathrm{U}$ & $10.8 \mathrm{U}$ & 13.7 & $20.8 \mathrm{U}$ \\
Phenanthrene & 305 & 241 & $22.7 \mathrm{U}$ & $22.7 \mathrm{U}$ & $43.4 \mathrm{U}$ \\
Anthracene & 171 & 128 & $19.1 \mathrm{U}$ & 20.6 & $36.5 \mathrm{U}$ \\
Fluoranthene & 1590 & 1350 & 71.9 & 70.5 & 77.5 \\
Pyrene & 1990 & 1660 & 208 & 158 & 213 \\
Benzo[a]anthracene & 863 & 765 & 63.9 & 67.1 & 67.8 \\
Chrysene & 891 & 757 & 44.7 & 46.8 & 52.7 \\
Benzo[b]fluoranthene & 910 & 787 & 125 & 101 & 141 \\
Benzo[k]fluoranthene & 118 & 96.3 & 19.7 & 41.1 & $24.4 \mathrm{U}$ \\
Benzo[a]pyrene & 471 & 389 & 53.8 & 57.2 & 63.4 \\
Indeno[123-cd]pyrene & 90.6 & 63.2 & $16.5 \mathrm{~B}$ & $15.6 \mathrm{U}$ & $24.9 \mathrm{U}$ \\
Dibenzo[a,h]anthracene & $22.6 \mathrm{~B}$ & $18.0 \mathrm{~B}$ & $10.3 \mathrm{U}$ & $11.1 \mathrm{U}$ & $19.8 \mathrm{U}$ \\
Benzo[g,h,i]perylene & 96.8 & $63.5 \mathrm{U}$ & $16.3 \mathrm{~B}$ & 23.3 & $17.4 \mathrm{U}$ \\
& & & & &
\end{tabular}


Table F.8. (contd)

Concentration $(\mu \mathrm{g} / \mathrm{kg}$ dry wt)

Sediment Treatment

Replicate

Analytical Replicate

Wet Weight (g)

Percent Dry Weight

Batch

1,4-Dichlorobenzene

Naphthalene

Acenaphthylene

Acenaphthene

Fluorene

Phenanthrene

Anthracene

Fluoranthene

Pyrene

Benzo[a]anthracene

Chrysene

Benzo[b]fluoranthene

Benzo[k]fluoranthene

Benzo[a]pyrene

Indeno[123-cd]pyrene

Dibenzo[a,h]anthracene

Benzo[g,h,i]perylene

M

\begin{tabular}{|c|c|c|c|c|}
\hline $\begin{array}{c}\text { MDRS } \\
4\end{array}$ & $\begin{array}{c}\text { MDRS } \\
5\end{array}$ & $\begin{array}{c}\text { Macoma Bkgd. } \\
\text { Tissue } \\
1\end{array}$ & $\begin{array}{l}\text { Macoma Bkgd. } \\
\text { Tissue } \\
2\end{array}$ & $\begin{array}{c}\text { Macoma Bkgd. } \\
\text { Tissue } \\
3\end{array}$ \\
\hline 20.7 & 20.2 & 14.3 & 10.2 & 10.5 \\
\hline 12.2 & 12.7 & 13.7 & 13.7 & 13.7 \\
\hline 1 & 2 & 2 & 2 & 2 \\
\hline $15.9 \mathrm{U}$ & $N A^{(e)}$ & $19.0 \mathrm{U}$ & $26.6 \mathrm{U}$ & $26.1 \mathrm{U}$ \\
\hline 24.4 & NA & $19.2^{(b)}$ & $26.6 \mathrm{U}$ & $26.1 \mathrm{U}$ \\
\hline $4.3 \mathrm{U}$ & NA & $7.42 \mathrm{U}$ & $10.3 \mathrm{U}$ & $10.1 \mathrm{U}$ \\
\hline $11.0 \mathrm{U}$ & NA & $13.3 \mathrm{U}$ & $18.6 \mathrm{U}$ & $18.2 \mathrm{U}$ \\
\hline $10.1 \mathrm{U}$ & NA & $12.6 \mathrm{U}$ & $17.6 \mathrm{U}$ & $17.2 \mathrm{U}$ \\
\hline 22.8 & NA & $26.1 \mathrm{U}$ & $36.5 U$ & $35.7 \mathrm{U}$ \\
\hline $17.8 \mathrm{U}$ & NA & $22.8 \mathrm{U}$ & $32.0 \mathrm{U}$ & $31.3 \mathrm{U}$ \\
\hline 67.9 & NA & $54.7 \mathrm{U}$ & $76.4 U$ & $75.0 \mathrm{U}$ \\
\hline 174 & NA & $46.6 \mathrm{U}$ & $65.1 \mathrm{U}$ & $63.8 \mathrm{U}$ \\
\hline 68.7 & NA & $18.3 \mathrm{~B}$ & $22.3 \mathrm{~B}$ & $22.6^{(c)}$ \\
\hline 52.6 & NA & $23.1 \mathrm{U}$ & $32.4 \mathrm{U}$ & $31.7 \mathrm{U}$ \\
\hline 135 & NA & $16.7 \mathrm{U}$ & $23.4 \mathrm{U}$ & $22.9 \mathrm{U}$ \\
\hline 19.6 & NA & $17.0 \mathrm{U}$ & $23.8 \mathrm{U}$ & $23.4 \mathrm{U}$ \\
\hline 60.1 & NA & $15.2 U$ & $21.3 \mathrm{U}$ & $20.9 \mathrm{U}$ \\
\hline $14.3 \mathrm{~B}$ & NA & $18.0 \mathrm{U}$ & $25.1 \mathrm{U}$ & $24.6 \mathrm{U}$ \\
\hline $9.65 U$ & NA & $12.8 U$ & $18.0 \mathrm{U}$ & $17.6 \mathrm{U}$ \\
\hline $14.8 \mathrm{~B}$ & NA & $14.3 \mathrm{U}$ & $20.0 \mathrm{U}$ & $19.6 \mathrm{U}$ \\
\hline
\end{tabular}

\footnotetext{
(a) U Undetected at or above given concentration.

(b) Ion ratio out or confirmation ion not detected.

(c) B Analyte detected in sample is $<5$ times blank value.

(d) MDRS Mud Dump Reference Site.

(e) NA Not available; sample dropped during processing.
} 
Table F.9. Quality Control Summary for Polynuclear Aromatic Hydrocarbon (PAH) Analysis of $M$. nasuta Tissue (Wet Weight)

\begin{tabular}{|c|c|c|c|c|c|c|c|}
\hline \multirow{4}{*}{$\begin{array}{l}\text { Sediment Treatment } \\
\text { Replicate }\end{array}$} & & & \multicolumn{5}{|c|}{ Matrix Spike Results } \\
\hline & & & \multicolumn{4}{|c|}{ Concentration $(\mu \mathrm{g} / \mathrm{kg}$ wet $w \mathrm{t})$} & \multirow{7}{*}{$\begin{array}{l}\text { Percent } \\
\text { Recovery }\end{array}$} \\
\hline & Blank & Blank & $\overline{\mathrm{BX} \text { COMP }}$ & $\mathrm{BX}$ COMP & \multirow{2}{*}{\multicolumn{2}{|c|}{ Concentration }} & \\
\hline & & NA & 5 & (MS) & & & \\
\hline Analytical Replicate & 1 & 1 & 1 & 1 & Spiked & Recovered & \\
\hline Wet Weight (g) & 20.0 & 20.0 & 9.97 & 10.8 & & & \\
\hline Percent Dry Weight & NA & NA & 13.6 & NA & & & \\
\hline Batch & 1 & 2 & 1 & 1 & 1 & & \\
\hline 1,4-Dichlorobenzene & $2.00 U^{(b)}$ & $2.35 \mathrm{U}$ & $4.01 \mathrm{U}$ & $3.70 \mathrm{U}$ & $N^{(c)}$ & $N A^{(d)}$ & NA \\
\hline Naphthalene & $1.85 U$ & $2.35 \mathrm{U}$ & 4.91 & 53.7 & 46.3 & 48.8 & 105 \\
\hline Acenaphthylene & $0.55 \mathrm{U}$ & $0.91 \mathrm{U}$ & $1.10 u$ & 38.0 & 46.3 & 38.0 & 82 \\
\hline Acenaphthene & $1.39 \mathrm{U}$ & $1.64 \mathrm{U}$ & $2.79 \mathrm{U}$ & 41.4 & 46.3 & 41.4 & 90 \\
\hline Fluorene & $1.28 \mathrm{U}$ & $1.56 \mathrm{U}$ & 2.75 & 48.5 & 46.3 & 45.8 & 99 \\
\hline Phenanthrene & $2.67 \mathrm{U}$ & $3.22 \mathrm{U}$ & 32.7 & 77.6 & 46.3 & 44.9 & 97 \\
\hline Anthracene & $2.25 \mathrm{U}$ & $2.82 \mathrm{U}$ & 17.5 & 63.4 & 46.3 & 45.9 & 99 \\
\hline Fluoranthene & $3.10 \mathrm{U}$ & $6.76 \mathrm{U}$ & 184 & 210 & 46.3 & 26.0 & 56 \\
\hline Pyrene & $2.79 \mathrm{U}$ & $5.76 \mathrm{U}$ & 226 & 266 & 46.3 & 40.0 & 86 \\
\hline Benzo[a]anthracene & 1.05 & $1.82^{(\mathrm{e})}$ & 104 & 147 & 46.3 & 43.0 & 93 \\
\hline Chrysene & $1.74 \mathrm{U}$ & $2.86 \mathrm{U}$ & 103 & 144 & 46.3 & 41.0 & 89 \\
\hline Benzo[b]fluoranthene & 1.49 & $2.07 \mathrm{U}$ & 107 & 222 & 46.3 & 115 & $248^{(f)}$ \\
\hline Benzo[k]fluoranthene & $1.50 \mathrm{U}$ & $2.10 \mathrm{U}$ & 13.1 & 61.6 & 46.3 & 48.5 & 105 \\
\hline Benzo[a]pyrene & $1.28 \mathrm{U}$ & $1.88 \mathrm{U}$ & 52.9 & 95.9 & 46.3 & 43.0 & 93 \\
\hline Indeno[123-cd]pyrene & 1.53 & $2.22 \mathrm{U}$ & 8.60 & 45.1 & 46.3 & 36.5 & 79 \\
\hline Dibenzo[a,h]anthracene & 1.30 & $1.59 \mathrm{U}$ & $2.45 \mathrm{U}$ & 38.3 & 46.3 & 38.3 & 83 \\
\hline Benzo[g,h,i]perylene & 1.25 & $1.77 \mathrm{U}$ & 8.64 & 38.0 & 46.3 & 29.4 & 63 \\
\hline \multicolumn{8}{|l|}{ Surrogate Recoveries (\%) } \\
\hline$\overline{d 4}$ 1,4-Dichlorobenzene & 64 & 78 & 40 & 36 & & NA & NA \\
\hline d8 Naphthalene & 69 & 85 & 48 & 44 & & NA & NA \\
\hline d10 Acenaphthene & 64 & 88 & 63 & 54 & & NA & NA \\
\hline d12 Chrysene & 61 & 92 & 62 & 60 & & NA & NA \\
\hline d14 Dibenzo[a,h]anthracene & $27^{(g)}$ & 113 & 49 & 45 & & NA & NA \\
\hline
\end{tabular}


Table F.9. (contd)

Matrix Spike Results

\begin{tabular}{|c|c|c|c|c|c|}
\hline \multirow{3}{*}{$\begin{array}{l}\text { Sediment Treatment } \\
\text { Replicate }\end{array}$} & \multirow{2}{*}{\multicolumn{4}{|c|}{ MDRS $^{(h)} \quad$ MDRS (MS) }} & \multirow{4}{*}{ Percent } \\
\hline & & & & & \\
\hline & 2 & & \multicolumn{2}{|c|}{ Concentration } & \\
\hline Analytical Replicate & 1 & 1 & Spiked & Recovered & \\
\hline Wet Weight (g) & 15.2 & 16.7 & & & \\
\hline Percent Dry Weight & 14.9 & NA & & & \\
\hline Batch & 2 & 2 & & & \\
\hline 1,4-Dichlorobenzene & $2.46 \mathrm{U}$ & $2.24 \mathrm{U}$ & NS & NA & NA \\
\hline Naphthalene & 2.62 & 38.9 & 30.0 & 36.3 & $121^{(f)}$ \\
\hline Acenaphthylene & $1.16^{(e)}$ & 30.4 & 30.0 & 29.2 & 97 \\
\hline Acenaphthene & $1.72 \mathrm{U}$ & 29.9 & 30.0 & 29.9 & 100 \\
\hline Fluorene & 2.04 & 30.6 & 30.0 & 28.6 & 95 \\
\hline Phenanthrene & $3.38 \mathrm{U}$ & 28.8 & 30.0 & 28.8 & 96 \\
\hline Anthracene & $3.07^{(\mathrm{e})}$ & 34.1 & 30.0 & 31.0 & 103 \\
\hline Fluoranthene & 10.5 & 40.7 & 30.0 & 30.2 & 101 \\
\hline Pyrene & 23.5 & 50.3 & 30.0 & 26.8 & 89 \\
\hline Benzo[a]anthracene & 10.0 & 42.7 & 30.0 & 32.7 & 109 \\
\hline Chrysene & 6.97 & 41.3 & 30.0 & 34.4 & 115 \\
\hline Benzo[b]fluoranthene & 15.1 & 50.9 & 30.0 & 35.8 & 119 \\
\hline Benzo[k]fluoranthene & 6.12 & 41.2 & 30.0 & 35.1 & 117 \\
\hline Benzo[a]pyrene & 8.53 & 40.0 & 30.0 & 31.5 & 105 \\
\hline Indeno[123-cd]pyrene & $2.33 \mathrm{U}$ & 30.6 & 30.0 & 30.6 & 102 \\
\hline Dibenzo[a,h]anthracene & $1.66 \mathrm{U}$ & 27.7 & 30.0 & 27.7 & 92 \\
\hline Benzo[g,h,i]perylene & 3.47 & 26.6 & 30.0 & 23.1 & 77 \\
\hline \multicolumn{6}{|l|}{ Surrogate Recoveries (\%) } \\
\hline d4 1,4-Dichlorobenzene & 48 & 66 & & NA & NA \\
\hline d8 Naphthalene & 59 & 74 & & NA & NA \\
\hline d10 Acenaphthene & 69 & 81 & & NA & NA \\
\hline d12 Chrysene & 68 & 80 & & NA & NA \\
\hline d14 Dibenzo[a,h]anthracene & 85 & 99 & & NA & NA \\
\hline
\end{tabular}


Table F.9. (contd)

Analytical Replicates

\begin{tabular}{|c|c|c|c|c|}
\hline \multirow[b]{2}{*}{ Sediment Treatment } & \multicolumn{3}{|c|}{ Concentration ( $\mu \mathrm{g} / \mathrm{kg}$ wet $\mathrm{wt})$} & \multirow[b]{3}{*}{ RSD } \\
\hline & $\mathrm{BX}$ COMP(a) & BX COMP & BX COMP & \\
\hline Replicate & 3 & 3 & 3 & \\
\hline Analytical Replicate & 1 & 2 & 3 & $(\%)$ \\
\hline Wet Weight (g) & 9.6 & 9.8 & 10.3 & \\
\hline Percent Dry Weight & 7.7 & 14.9 & 19.8 & \\
\hline Batch & 1 & 1 & 1 & \\
\hline 1,4-Dichlorobenzene & $4.18 \mathrm{U}$ & $4.09 \mathrm{U}$ & $3.88 \mathrm{U}$ & NA \\
\hline Naphthalene & 6.46 & 5.85 & 6.13 & 5 \\
\hline Acenaphthylene & 1.65 & $1.12 \mathrm{U}$ & $1.07 \mathrm{U}$ & NA \\
\hline Acenaphthene & 4.63 & 3.24 & 2.90 & 26 \\
\hline Fluorene & 4.78 & 4.35 & 3.70 & 13 \\
\hline Phenanthrene & 40.5 & 33.9 & 36.5 & 9 \\
\hline Anthracene & 24.0 & 19.3 & 19.9 & 12 \\
\hline Fluoranthene & 233 & 182 & 191 & 13 \\
\hline Pyrene & 312 & 265 & 263 & 10 \\
\hline Benzo[a]anthracene & 118 & 99.9 & 103 & 9 \\
\hline Chrysene & 113 & 92.2 & 97.6 & 11 \\
\hline Benzo[b]fluoranthene & 128 & 97.1 & 101 & 15 \\
\hline Benzo[k]fluoranthene & 15.8 & 12.1 & 12.3 & 15 \\
\hline Benzo[a]pyrene & 61.4 & 47.3 & 49.2 & 14 \\
\hline Indeno[123-cd]pyrene & 9.92 & $7.25 \mathrm{~B}^{(1)}$ & 8.11 & 16 \\
\hline Dibenzo[a,h]anthracene & $3.16 \mathrm{~B}$ & $2.49 \mathrm{U}$ & $2.53 \mathrm{~B}$ & NA \\
\hline Benzo[g,h,i]perylene & 10.6 & 7.40 & 8.44 & 19 \\
\hline \multicolumn{5}{|l|}{ Surrogate Recoveries (\%) } \\
\hline$\overline{d 44 \text { 1,4-Dichlorobenzene }}$ & 48 & 41 & 45 & NA \\
\hline d8 Naphthalene & 53 & 47 & 50 & NA \\
\hline d10 Acenaphthene & 49 & 50 & 57 & NA \\
\hline d12 Chrysene & 52 & 48 & 51 & NA \\
\hline d14 Dibenzo[a,h]anthracene & 33 & 31 & 31 & NA \\
\hline
\end{tabular}


Table F.9. (contd)

Analytical Replicates

\begin{tabular}{l} 
Sediment Treatment \\
Replicate \\
Analytical Replicate \\
Wet Weight (g) \\
Percent Dry Weight \\
Batch \\
\hline
\end{tabular}

1,4-Dichlorobenzene

Naphthalene

Acenaphthylene

Acenaphthene

Fluorene

Phenanthrene

Anthracene

Fluoranthene

Pyrene

Benzo[a]anthracene

Chrysene

Benzo[b]fluoranthene

Benzo[k]fluoranthene

Benzo[a]pyrene

Indeno[123-cd]pyrene

Dibenzo[a,h]anthracene

Benzo[g,h,i]perylene

Maco

Concentration $(\mu g / k g$ wet $w t)$
Bkgd. Macoma Bkgd. Macom

Tissue Macoma Bkgd.

1

14.3

14.0

2

10.2

13.8

$2 \quad 2$

$2.61 \mathrm{U}$

$2.64^{\text {(e) }}$

$3.65 \mathrm{U}$

$3.65 \mathrm{U}$

$3.58 \mathrm{U}$

NA

$1.02 \mathrm{U}$

$1.42 \mathrm{U}$

$3.58 \mathrm{U}$

$2.56 \mathrm{U}$

$1.39 \mathrm{U}$

$2.50 \mathrm{U}$

$1.73 \mathrm{U}$

$2.42 \mathrm{U}$

$2.37 \mathrm{U}$

$5.02 \mathrm{U}$

$4.91 \mathrm{U}$

$4.39 \mathrm{U}$

$4.30 \mathrm{U}$

$10.5 \mathrm{U}$

$10.3 \mathrm{U}$

$8.95 \mathrm{U}$

$8.77 \mathrm{U}$

$3.06^{(e)}$

$3.11^{(e)}$

$4.45 \mathrm{U}$

$4.35 \mathrm{U}$

$3.22 \mathrm{U}$

$3.15 \mathrm{U}$

3.27 U

$3.21 \mathrm{U}$

$2.87 \mathrm{U}$

$2.93 \mathrm{U}$

$3.45 \mathrm{U}$

$2.47 \mathrm{U}$

$3.38 \mathrm{U}$

$2.42 \mathrm{U}$

$2.75 \mathrm{U}$
RSD

(\%)
$1.76 \mathrm{U}$

$1.96 \mathrm{U}$

$2.69 \mathrm{U}$

NA

NA

NA

NA

NA

NA

NA

NA

11

NA

NA

NA

NA

NA

NA

NA

Surrogate Recoveries (\%)

d4 1,4-Dichlorobenzene

$\begin{array}{rr}42 & 63 \\ 52 & 73 \\ 67 & 80 \\ 87 & 79 \\ 108 & 96\end{array}$

48
61
71
82
101

NA

NA

NA

NA

d14 Dibenzo[a,h]anthracene

96

NA

(a) Sample randomly selected for use as a quality control sample in analytical batch.

(b) U Undetected at or above given concentration.

(c) NS Not spiked.

(d) NA Not applicable.

(e) Ion ratio out or confirmation ion not detected.

(f) Outside quality control criteria (50-120\%) for spike recovery.

(g) Outside quality control criteria (30-150\%) for surrogate recovery.

(h) MDRS Mud Dump Reference Site.

(i) B Analyte detected in sample is $<5$ times blank value. 
Table F.10. Lipids in Tissue of $M$. nasuta

\begin{tabular}{lccc} 
Sample ID & $\begin{array}{c}\% \text { Dry } \\
\text { Weight }\end{array}$ & $\begin{array}{c}\text { \% Lipid } \\
\text { (wet wt) }\end{array}$ & $\begin{array}{c}\% \text { Lipid } \\
\text { (dry wt) }\end{array}$ \\
\hline Macoma Bkgd. Tissue & 13.73 & 0.80 & 5.83 \\
Macoma Bkgd. Tissue & 13.73 & 0.98 & 7.14 \\
Macoma Bkgd. Tissue & 13.73 & 0.80 & 5.83
\end{tabular}





\section{Appendix G}

\section{Nereis virens Tissue Chemical Analyses and Quality Assurance/Quality Control Data, Bronx River Project}





\section{QA/QC SUMMARY}

PROGRAM: $\quad$ New York Federal Projects 5

PARAMETER: Metals

LABORATORY: Battelle/Marine Sciences Laboratory, Sequim, Washington

MATRIX: $\quad$ Worm Tissue

QA/QC DATA QUALITY OBJECTIVES

\begin{tabular}{|c|c|c|c|c|c|}
\hline & $\begin{array}{c}\text { Reference } \\
\text { Method }\end{array}$ & $\begin{array}{l}\text { Range of } \\
\text { Recovery }\end{array}$ & $\begin{array}{c}\text { SRM } \\
\text { Accuracy }\end{array}$ & $\begin{array}{r}\text { Relative } \\
\text { Precision } \\
\end{array}$ & $\begin{array}{c}\text { Target } \\
\text { Detection } \\
\text { Limit(dry wt) }\end{array}$ \\
\hline Arsenic & ICP/MS & $75-125 \%$ & $\leq 20 \%$ & $\leq 20 \%$ & $1.0 \mathrm{mg} / \mathrm{kg}$ \\
\hline Cadmium & ICP/MS & $75-125 \%$ & $\leq 20 \%$ & $\leq 20 \%$ & $0.1 \mathrm{mg} / \mathrm{kg}$ \\
\hline Chromium & ICP/MS & $75-125 \%$ & $\leq 20 \%$ & $\leq 20 \%$ & $0.2 \mathrm{mg} / \mathrm{kg}$ \\
\hline Copper & ICP/MS & $75-125 \%$ & $\leq 20 \%$ & $\leq 20 \%$ & $1.0 \mathrm{mg} / \mathrm{kg}$ \\
\hline Lead & ICP/MS & $75-125 \%$ & $\leq 20 \%$ & $\leq 20 \%$ & $0.1 \mathrm{mg} / \mathrm{kg}$ \\
\hline Mercury & CVAA & $75-125 \%$ & $\leq 20 \%$ & $\leq 20 \%$ & $0.02 \mathrm{mg} / \mathrm{kg}$ \\
\hline Nickel & ICP/MS & $75-125 \%$ & $\leq 20 \%$ & $\leq 20 \%$ & $0.1 \mathrm{mg} / \mathrm{kg}$ \\
\hline Silver & ICP/MS & $75-125 \%$ & $\leq 20 \%$ & $\leq 20 \%$ & $0.1 \mathrm{mg} / \mathrm{kg}$ \\
\hline Zinc & ICP/MS & $75-125 \%$ & $\leq 20 \%$ & $\leq 20 \%$ & $1.0 \mathrm{mg} / \mathrm{kg}$ \\
\hline
\end{tabular}

METHOD

Nine metals were analyzed for the New York 5 Program: silver (Ag), arsenic (As), cadmium (Cd), chromium $(\mathrm{Cr})$, copper $(\mathrm{Cu})$, mercury $(\mathrm{Hg})$, nickel $(\mathrm{Ni})$, lead $(\mathrm{Pb})$ and zinc $(\mathrm{Zn})$. Hg was analyzed using cold-vapor atomic absorption spectroscopy (CVAA) according to the method of Bloom and Crecelius (1983). The remaining metals were analyzed by inductively coupled plasma mass spectrometry (ICP/MS) following a procedure based on EPA Method 200.8 (EPA 1991).

To prepare tissue for analysis, samples were freeze-dried and blended in a Spex mixer-mill. Approximately $5 \mathrm{~g}$ of mixed sample was ground in a ceramic ball mill. For ICP/MS and CVAA analyses, 0.2- to 0.5-g aliquots of dried homogenous sample were digested using a mixture of nitric acid and hydrogen peroxide following a modified version of EPA Method 200.3 (EPA 1991).

HOLDING TIMES Tissue samples were received on 7/13/95 in good condition. Samples were entered into Battelle's log-in system, frozen to $-80^{\circ} \mathrm{C}$, and subsequently freeze dried within approximately 7 days of sample receipt. Samples were analyzed within 180 days of collection. 


\section{QA/QC SUMMARY METALS (continued)}

The following table summarizes the analysis dates:

Task

Sample Digestion

ICP-MS

CVAA-Hg
Date Performed

$8 / 15 / 95$

$8 / 29 / 95$

$8 / 25 / 95$
DETECTION LIMITS

METHOD BLANKS

MATRIX SPIKES

REPLICATES

SRMs

\section{REFERENCES}

Bloom, N. S., and E.A. Crecelius. 1983. Determination of Mercury in Seawater at SubNanogram per Liter Levels. Mar. Chem. 14:49-59.

EPA (U.S. Environmental Protection Agency). 1991. Methods for the Determination of Metals in Environmental Samples. EPA-600/4-91-010. U.S. Environmental Protection Agency, Environmental Services Division, Monitoring Management Branch, Washington D.C. 
QAIQC SUMMARY

PROGRAM:

PARAMETER:

LABORATORY:

MATRIX:
New York Federal Projects 5

Chlorinated Pesticides/PCB Congeners

Battelle/Marine Sciences Laboratory, Sequim, Washington

Worm Tissue

QA/QC DATA QUALITY OBJECTIVES

Reference
Method

GC/ECD

METHOD

HOLDING TIMES

\begin{tabular}{lcc} 
Surrogate & $\begin{array}{c}\text { Spike } \\
\text { Recovery }\end{array}$ & $\begin{array}{c}\text { Relative } \\
\text { Recovery }\end{array}$ \\
\hline
\end{tabular}

$30-150 \%$
$50-120 \%$ $\leq 30 \%$

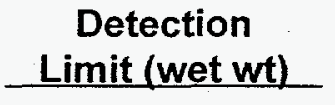

$0.4 \mu \mathrm{g} / \mathrm{kg}$

Tissues were homogenized wet using a stainless steel blade. An aliquot of tissue sample was extracted with methylene chloride using the roller technique under ambient conditions following a procedure based on methods used by the National Oceanic and Atmospheric Administration for its Status and Trends Program (NOAA 1993). Samples were then cleaned using silica/alumina ( $5 \%$ deactivated) chromatography followed by high performance liquid chromatography (HPLC) cleanup. Extracts were analyzed for 15 chlorinated pesticides and 22 PCB congeners using gas chromatography/electron capture detection (GC/ECD) following a procedure based on EPA Method 8080 (EPA 1986). The column used was a J\&W DB-17 and the confirmatory column was a DB1701 , both capillary columns $(30 \mathrm{~m} \times 0.25 \mathrm{~mm}$ I.D.). All detections were quantitatively confirmed on the second column.

Samples of worm tissue were received on 7/13/95 in good condition. Samples were entered into Battelle's log-in system and stored frozen until extraction. Samples were extracted in two batches. The following summarizes the extraction and analysis dates:

\begin{tabular}{clcc} 
Batch & Species & Extraction & Analysis \\
\hline 1 & $N$. virens & $9 / 28 / 95$ & $10 / 19-20 / 95$ \\
2 & $M$. nasuta/N. virens & $10 / 16 / 95$ & $10 / 20-21 / 95$
\end{tabular}




\section{QA/QC SUMMARYIPCBS and PESTICIDES (continued)}

DETECTION LIMITS

METHOD BLANKS

SURROGATES

MATRIX SPIKES

REPLICATES

SRMs

MISCELLANEOUS
Target detection limits of $0.4 \mu \mathrm{g} / \mathrm{kg}$ wet weight were met for most pesticides and PCB congeners. Method detection limits (MDLs) reported were determined by multiplying the standard deviation of seven spiked replicates of worm tissue by the student's t-value at the 99th percentile $(t=3.142)$. MDLs were reported corrected for individual sample wet weight extracted.

One method blank was extracted with each extraction batch. No pesticides or PCBs were detected in any of the method blanks, with the exception of aldrin in the blank from batch 1 . The amount in the blank was less than three times the MDL; therefore, no further action was taken.

Two compounds, PCB congeners 103 and 198, were added to all samples prior to extraction to assess the efficiency of the analysis. Sample surrogate recoveries were all within the QC guidelines of $30 \%-120 \%$. Sample results were quantified based on surrogate recoveries.

Eleven out of the 15 pesticides and 5 of the 22 PCB congeners analyzed were spiked into one sample per extraction batch. Matrix spike recoveries were within the control limit range of $50 \%-120 \%$ for all pesticides and PCBs, with the exception of heptachlor $(126 \%)$ and PCB 101 (123\%) in batch 1.

One sample from each extraction batch was analyzed in triplicate. Precision was measured by calculating the relative standard deviation (RSD) between the replicate results. RSDs for all detectable values were below the target precision goal of $\leq 30 \%$

An appropriate SRM for chlorinated organics in tissues was not available from National Institute of Standards and Technology at the time of these analyses.

All pesticide and PCB congener results are confirmed using a second dissimilar column. RSDs between the primary and confirmation values must be less than $75 \%$ to be considered a confirmed value. 


\section{QA/QC SUMMARYIPCBs and PESTICIDES (continued)}

\section{REFERENCES}

NYSDEC (New York Department of Environmental Conservation). 1992. Analytical Method for the Determination of PCB congeners by Fused Silica Capillary Column Gas Chromatography with Electron Capture Detector. NYSDEC Method 91-11. New York State Department of Environmental Conservation, Albany, New York.

EPA (U.S. Environmental Protection Agency). 1986. Test Methods for Evaluating Solid Waste: Physical/Chemical Methods. SW-846. U.S. Document No. 955-001-00000, U.S. Environmental Protection Agency, Washington D. C. 


\section{QA/QC SUMMARY}

PROGRAM:

PARAMETER:

LABORATORY:

MATRIX:
New York Federal Projects 5

Polynuclear Aromatic Hydrocarbons (PAH) and 1,4-Dichlorobenzene

Battelle/Marine Sciences Laboratory, Sequim, Washington

Worm Tissue

QAVQC DATA QUALITY OBJECTIVES

$\begin{array}{cccccc}\begin{array}{c}\text { Reference } \\ \text { Method }\end{array} & \begin{array}{c}\text { MS } \\ \text { Recovery }\end{array} & \begin{array}{c}\text { Surrogate } \\ \text { Recovery }\end{array} & \begin{array}{c}\text { SRM } \\ \text { Accuracy }\end{array} & \begin{array}{c}\text { Relative } \\ \text { Precision }\end{array} & \begin{array}{c}\text { Detection } \\ \text { Limit (wet wt) }\end{array} \\ \text { GC/MS/SIM } & 50-120 \% & 30-150 \% & \leq 30 \% & \leq 30 \% & 4 \mathrm{ng} / \mathrm{g}\end{array}$

METHOD

HOLDING TIMES
Tissue samples were extracted with methylene chloride following a procedure based on methods used by the National Oceanic and Atmospheric Administration for its Status and Trends Program (NOAA 1993). Samples were then cleaned using silica/alumina ( $5 \%$ deactivated) chromatography followed by high performance liquid chromatography (HPLC) cleanup.

Extracts were quantified using gas chromatography/mass spectrometry (GC/MS) in the selected ion mode (SIM) following a procedure based on EPA Method 8270 (NOAA 1993).

Samples of worm tissue were received on 7/13/95 in good condition. Samples were entered into Battelle's log-in system and stored frozen until extraction. The following summarizes the extraction and analysis dates:

\begin{tabular}{llll} 
Batch & Species & Extraction & $\frac{\text { Analysis }}{10 / 19-20 / 95}$ \\
\cline { 2 - 4 } & N. virens & $9 / 28 / 95$ & $10 / 20-21 / 95$
\end{tabular}


DETECTION LIMITS

\section{METHOD BLANKS}

\section{SURROGATES}

MATRIX SPIKES
Target detection limits of $4 \mu \mathrm{g} / \mathrm{kg}$ wet weight were met for all PAH compounds except for fluoranthene and pyrene, which had method detection limits (MDL) between 4 and $6 \mu \mathrm{g} / \mathrm{kg}$ wet weight. MDLs were determined by multiplying the standard deviation of seven spiked replicates of a background clam sample by the student's t-value at the 99th percentile $(t=3.142)$. These MDLs were based on a wet weight of 20 grams of tissue sample. Aliquots of samples that were analyzed in triplicate, used for spiking, or were reextracted, were generally less than $\mathbf{2 0}$ grams due to limited quantities of tissue available. Because MDLs reported are corrected for sample weight, the MDLs reported for these samples appear elevated and in some cases may exceed the target detection limit.

One method blank was extracted with each extraction batch. No PAHs were detected in the blanks, with the exception of naphthalene in batch 1 and fluorene and benz[a]anthracene in batch 2. All levels were less than three times the MDL. A number of sample values, however, that were less than five times the blank concentration were reported and flagged with a "B" to indicate that these values could be biased high due to blank contamination. Sample values greater than five times the blank concentration are not significantly affected by the blank contamination and were therefore not flagged.

Five isotopically labeled compounds were added prior to extraction to assess the efficiency of the method. These were d8-naphthalene, d10acenaphthene, d12-chrysene, d14-dibenz[a,h]anthracene and d4-1,4 dichlorobenzene. Recoveries of all surrogates were within the quality control limits of $30 \%-150 \%$. Results were quantified using the surrogate internal standard method.

One sample from each batch was spiked with all PAH compounds. Matrix spike recoveries were generally within QC limits of $50 \%-120 \%$, with some exceptions. Spike recoveries for four PAH compounds in batch 1 were high; however, no recovery exceeded $144 \%$. Naphthalene was recovered slightly above the upper control limit in batch 2. 


\section{QA/QC SUMMARYIPAHs (continued)}

REPLICATES

SRMs

MISCELLANEOUS
One sample from each batch was extracted and analyzed in triplicate. Precision was measured by calculating the relative standard deviation (RSD) between the replicate results. Two compounds were detected in all three replicates in batch 1 , and one compound was detected in all three replicates in batch 2 . All RSDs were within $\pm 30 \%$.

An appropriate SRM for PAHs in tissues was not available from NIST at the time of these analyses.

For several compounds the ion-ratio was outside of the $\mathrm{QC}$ range, due to low levels in the native sediment. When the native levels are low, the error associated with the concentration measurement of the confirmation ion, which is present at a fraction of the parent ion concentration, increases. Because the confirmation ion is quantified solely from the parent ion, this will not affect the quality of the data.

\section{REFERENCES}

NOAA (National Oceanic and Atmospheric Administration). 1993. Sampling and Analytical Methods of the National Status and Trends Program, National Benthic Surveillance and Mussel Watch Projects 1984-1992. Volume IV. Comprehensive Descriptions of Trace Organic Analytical Methods. G.G. Lauenstein and A.Y. Cantillo, eds. NOAA Technical Memorandum NOS ORCA 71. National Oceanic and Atmospheric Administration, Coastal Monitoring and Bioeffects Assessment Division, Office of Resources Conservation and Assessment, Silver Spring, Maryland.

EPA (U.S. Environmental Protection Agency). 1986. Test Methods for Evaluating Solid Waste: Physical/Chemical Methods. SW-846. U.S. Document No. 955-001-00000, U.S. Environmental Protection Agency, Washington D.C. 
Table G.1. Metals in N. virens Tissue (Wet Weight), Bronx River

\begin{tabular}{|c|c|c|c|c|c|c|c|c|c|c|c|c|c|}
\hline \multirow[b]{2}{*}{$\begin{array}{l}\text { Sediment } \\
\text { Treatment }\end{array}$} & \multirow[b]{2}{*}{ Replicate } & \multirow[b]{2}{*}{$\begin{array}{l}\text { Analytica } \\
\text { Replicate }\end{array}$} & \multirow[b]{2}{*}{ Batch } & \multirow[b]{2}{*}{$\begin{array}{c}\text { Percent } \\
\text { Dry Weight }\end{array}$} & \multicolumn{9}{|c|}{ Concentration (mg/kg wet wt) } \\
\hline & & & & & $\begin{array}{c}\mathrm{Ag} \\
\text { ICP/MS } \\
\end{array}$ & $\begin{array}{c}\text { As } \\
\text { ICPMS }\end{array}$ & $\begin{array}{c}\mathrm{Cd} \\
\mathrm{ICP} / \mathrm{MS}\end{array}$ & $\begin{array}{c}\mathrm{Cr} \\
\mathrm{ICP} / \mathrm{MS}\end{array}$ & $\begin{array}{c}\mathrm{CU} \\
\text { ICPMS }\end{array}$ & $\begin{array}{c}\mathrm{Hg} \\
\text { CVAA } \\
\end{array}$ & $\begin{array}{c}\mathrm{Ni} \\
\text { ICPMS }\end{array}$ & $\begin{array}{c}\mathrm{Pb} \\
\text { ICP/MS }\end{array}$ & $\begin{array}{c}\mathrm{Zn} \\
\text { ICPMS }\end{array}$ \\
\hline BX COMP & 1 & 1 & 1 & 14.0 & $0.031 U^{(a)}$ & 1.86 & 0.0592 & $0.0118 \mathrm{U}$ & 1.06 & 0.0304 & 0.0597 & 0.190 & 706 \\
\hline$B \times C O M P$ & 1 & 2 & 1 & 14.0 & $0.031 \mathrm{U}$ & 1.76 & 0.0540 & $0.0118 U$ & 1.00 & 0.0292 & 0.0448 & 0.183 & 6.79 \\
\hline BX COMP & 1 & 3 & 1 & 14.0 & $0.031 \mathrm{U}$ & 1.90 & 0.0590 & $0.0118 \mathrm{U}$ & 1.06 & 0.0311 & 0.0579 & 0.201 & 7.16 \\
\hline BX COMP & 2 & & 1 & 15.2 & $0.034 \mathrm{U}$ & 2.70 & 0.0472 & $0.0129 U$ & 0.973 & 0.0510 & 0.0436 & 0.164 & 7.05 \\
\hline BX COMP & 3 & & 1 & 15.3 & $0.034 \mathrm{U}$ & 2.58 & 0.0473 & $0.0129 \mathrm{U}$ & 1.18 & 0.0148 & 0.0891 & 0.179 & 7.26 \\
\hline BX COMP & 4 & & 1 & 14.2 & $0.031 \mathrm{U}$ & 2.02 & 0.0550 & $0.0120 \mathrm{U}$ & 1.31 & 0.0459 & 0.0879 & 0.144 & 6.24 \\
\hline$B \times C O M P$ & 5 & & 1 & 16.0 & $0.035 \mathrm{U}$ & 2.43 & 0.0608 & $0.0135 \mathrm{U}$ & 1.43 & 0.0286 & 0.0670 & 0.230 & 8.73 \\
\hline $\operatorname{MDRS}^{(D)}$ & 1 & & 1 & 16.2 & $0.036 \mathrm{U}$ & 3.74 & 0.0797 & $0.0137 \mathrm{U}$ & 1.70 & 0.0181 & 0.0543 & 0.181 & 7.87 \\
\hline MDRS & 2 & & 1 & 13.9 & $0.031 \mathrm{U}$ & 3.19 & 0.0591 & 0.0528 & 1.42 & 0.0208 & 0.0822 & 0.164 & 9.99 \\
\hline MDRS & 3 & & 1 & 13.8 & $0.030 \mathrm{U}$ & 2.89 & 0.0626 & $0.0116 \mathrm{U}$ & 1.30 & 0.0267 & $0.0345 \mathrm{U}$ & 0.168 & 6.75 \\
\hline MDRS & 4 & & 1 & 18.9 & $0.042 U$ & 4.19 & 0.0893 & 0.0363 & 2.30 & 0.0234 & $0.0472 \mathrm{U}$ & 0.323 & 10.5 \\
\hline MDRS & 5 & & 1 & 15.0 & $0.033 \mathrm{U}$ & 2.40 & 0.0734 & 0.0879 & 1.43 & 0.0392 & 0.0710 & 0.211 & 7.63 \\
\hline Nereis Bkgd. Tissue & 1 & 1 & 1 & 7.7 & $0.017 \mathrm{U}$ & 1.58 & 0.0353 & 0.00933 & 0.69 & 0.0105 & 0.0487 & 0.067 & 4.22 \\
\hline Nereis Bkgd. Tissue & 1 & 2 & 1 & 14.9 & $0.033 \mathrm{U}$ & 2.40 & 0.0651 & 0.0201 & 1.20 & 0.0335 & 0.0733 & 0.150 & 8.14 \\
\hline Nereis Bkgd. Tissue & 1 & 3 & 1 & 19.8 & $0.043 \mathrm{U}$ & 3.48 & 0.105 & 0.0271 & 1.55 & 0.0451 & 0.0998 & 0.172 & 10.8 \\
\hline
\end{tabular}

(a) U Undetected at or above given concentration.

(b) MDRS Mud Dump Reference Site. 
Table G.2. Metals in N. virens Tissue (Dry Weight), Bronx River

\begin{tabular}{|c|c|c|c|c|c|c|c|c|c|c|c|c|c|}
\hline \multirow[b]{2}{*}{$\begin{array}{l}\text { Sediment } \\
\text { Treatment }\end{array}$} & \multirow[b]{2}{*}{ Replicate } & \multirow{2}{*}{\multicolumn{2}{|c|}{$\begin{array}{l}\text { Analytical } \\
\text { Replicate Batch }\end{array}$}} & \multirow[b]{2}{*}{$\begin{array}{c}\text { Percent } \\
\text { Dry Weight }\end{array}$} & \multicolumn{9}{|c|}{ Concentration (mg/kg dry wt) } \\
\hline & & & & & $\begin{array}{c}\mathrm{Ag} \\
\mathrm{ICP} / \mathrm{MS} \\
\end{array}$ & $\begin{array}{c}\text { As } \\
\text { ICP/MS } \\
\end{array}$ & $\begin{array}{c}\mathrm{Cd} \\
\text { ICP/MS } \\
\end{array}$ & $\begin{array}{c}\mathrm{Cr} \\
\mathrm{ICP} / \mathrm{MS} \\
\end{array}$ & $\begin{array}{c}\mathrm{Cu} \\
\mathrm{ICP} / \mathrm{MS}\end{array}$ & $\begin{array}{c}\mathrm{Hg} \\
\text { CVAA }\end{array}$ & $\begin{array}{c}\mathrm{Ni} \\
\text { ICP/MS }\end{array}$ & $\begin{array}{c}\mathrm{Pb} \\
\text { ICP/MS }\end{array}$ & $\begin{array}{c}\mathrm{Zn} \\
\text { ICP/MS }\end{array}$ \\
\hline & rget Detect & tion Limit: & & & 0.1 & 1.0 & 0.1 & 0.2 & 1.0 & 0.02 & 0.1 & 0.1 & 1.0 \\
\hline & hod Detect & tion Limit: & & & 0.22 & 0.830 & 0.0810 & 0.0845 & 1.20 & 0.0011 & 0.25 & 0.08 & 1.37 \\
\hline $\mathrm{BX}$ COMP & 1 & 1 & 1 & 14.0 & $0.22 U^{(a)}$ & 13.3 & 0.423 & $0.0845 \mathrm{U}$ & 7.55 & 0.217 & 0.427 & 1.36 & 50.5 \\
\hline BX COMP & 1 & 2 & 1 & 14.0 & $0.22 \mathrm{U}$ & 12.6 & 0.386 & $0.0845 U$ & 7.15 & 0.209 & 0.320 & 1.31 & 48.5 \\
\hline$B X$ COMP & 1 & 3 & 1 & 14.0 & $0.22 U$ & 13.6 & 0.422 & $0.0845 \mathrm{U}$ & 7.57 & 0.222 & 0.414 & 1.44 & 51.2 \\
\hline$B \times$ COMP & 2 & & 1 & 15.2 & $0.22 \mathrm{U}$ & 17.7 & 0.310 & $0.0845 \mathrm{U}$ & 6.39 & 0.335 & 0.286 & 1.08 & 46.3 \\
\hline BX COMP & 3 & & 1 & 15.3 & $0.22 \mathrm{U}$ & 16.9 & 0.310 & $0.0845 \mathrm{U}$ & 7.73 & 0.0968 & 0.584 & 1.17 & 47.6 \\
\hline BX COMP & 4 & & 1 & 14.2 & $0.22 \mathrm{U}$ & 14.2 & 0.387 & $0.0845 \mathrm{U}$ & 9.19 & 0.323 & 0.618 & 1.01 & 43.9 \\
\hline BX COMP & 5 & & 1 & 16.0 & $0.22 U$ & 15.2 & 0.381 & $0.0845 \mathrm{U}$ & 8.95 & 0.179 & 0.420 & 1.44 & 54.7 \\
\hline MDRS $^{(b)}$ & 1 & & 1 & 16.2 & $0.22 \mathrm{U}$ & 23.1 & 0.492 & $0.0845 \mathrm{U}$ & 10.5 & 0.112 & 0.335 & 1.12 & 48.6 \\
\hline MDRS & 2 & & 1 & 13.9 & $0.22 U$ & 22.9 & 0.424 & 0.379 & 10.2 & 0.149 & 0.590 & 1.18 & 71.7 \\
\hline MDRS & 3 & & 1 & 13.8 & $0.22 \mathrm{U}$ & 21.0 & 0.454 & $0.0845 \mathrm{U}$ & 9.45 & 0.194 & $0.25 U$ & 1.22 & 49.0 \\
\hline MDRS & 4 & & 1 & 18.9 & $0.22 \mathrm{U}$ & 22.2 & 0.473 & 0.192 & 12.2 & 0.124 & $0.25 \mathrm{U}$ & 1.71 & 55.7 \\
\hline MDRS & 5 & & 1 & 15.0 & $0.22 \mathrm{U}$ & 16.0 & 0.490 & 0.587 & 9.56 & 0.262 & 0.474 & 1.41 & 51.0 \\
\hline Nereis Bkgd. Tissue & 1 & 1 & 1 & 7.7 & $0.22 U$ & 20.6 & 0.462 & 0.122 & 9.05 & 0.137 & 0.637 & 0.873 & 55.1 \\
\hline Nereis Bkgd. Tissue & 1 & 2 & 1 & 14.9 & $0.22 \mathrm{U}$ & 16.1 & 0.437 & 0.135 & 8.08 & 0.225 & 0.492 & 1.01 & 54.7 \\
\hline Nereis Bkgd. Tissue & 1 & 3 & 1 & 19.8 & $0.22 \mathrm{U}$ & 17.6 & 0.530 & 0.137 & 7.82 & 0.228 & 0.505 & 0.870 & 54.7 \\
\hline
\end{tabular}

(a) U Undetected at or above given concentration.

(b) MDRS Mud Dump Reference Site. 
Table G.3. Quality Control Data for Metals Analysis of N. virens Tissue (Dry Weight)

Sediment
Treatment

Analytical

$\begin{array}{ccc}\mathrm{Ag} & \mathrm{As} & \mathrm{Cd}\end{array}$

Concentration (mg/kg dry wt) Replicate Replicate Ba

Blank

Blank

1

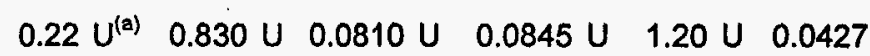

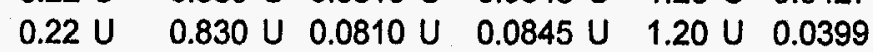

$0.25 U$

$0.25 \mathrm{U}$

$1.37 \cup$

Matrix Spike Results

SH COMP(b)

SH COMP (MS)

Concentration Spiked

Concentration Recovered

Percent Recovered

$B X \operatorname{COMP}^{(b)}$

BX COMP (MS)

Concentration Spiked

( C) Concentration Recovered

$\omega$ Percent Recovered

5

Standard Reference Material

$1566 a$

$1566 \mathrm{a}$

Certified Value

$$
\text { Range }
$$

Percent Difference

Analytical Replicates

SR COMP(b)
SR COMP
SR COMP

5
5
5

$\begin{array}{rrrr}1 & 1 & 0.22 U & 14.3 \\ 2 & 1 & 0.22 U & 14.6 \\ 3 & 1 & 0.22 U & 14.2 \\ & & \text { NA } & 1\end{array}$

0.324
1.22
1.00
0.896
90

$\begin{array}{cc}0.0845 \cup & 6.51 \\ 1.09 & 31.7 \\ 1.00 & 25.0 \\ 1.09 & 25.2 \\ 109 & 101 \\ & \end{array}$

$\begin{array}{rrrr}0.0920 & 0.674 & 0.752 & 46.4 \\ 1.12 & 1.69 & 1.57 & 69.1 \\ 1.00 & 1.00 & 1.00 & 25.0 \\ 1.03 & 1.02 & 0.818 & 22.7 \\ 103 & 102 & 82 & 91 \\ & & & \\ 0.0905 & 0.478 & 0.905 & 52.1 \\ 1.03 & 1.65 & 2.46 & 70.7 \\ 1.00 & 1.00 & 1.00 & 25.0 \\ 0.940 & 1.17 & 1.56 & 18.6 \\ 94 & 117 & 156^{(c)} & 74^{(c)}\end{array}$

$\begin{array}{rrrr}1 & 1 & 1.58 & 14 \\ 2 & 1 & 1.59 & 14 \\ & & & \\ & & 1.68 & 14 \\ & & \pm 0.15 & \pm 1\end{array}$

\begin{tabular}{|c|c|}
\hline 0.273 & $0.0845 \mathrm{U}$ \\
\hline 1.22 & 1.17 \\
\hline 1.00 & 1.00 \\
\hline 0.947 & 1.17 \\
\hline 95 & 117 \\
\hline
\end{tabular}

4.08

$0.0845 \cup \quad 70.7$

$\begin{array}{cc}0.0845 \cup & 70.7 \\ 0.113 & 70.7\end{array}$

0.0738

3.92

$\begin{array}{lr}14.0 & 4.15 \\ \pm 1.2 & \pm 0.38\end{array}$

1.43
\pm 0.46

0.0620

1.71

0.351

0.314

838

$$
\text { NA }
$$

66.3

0.0642

2.25

0.371

830

2

NA ${ }^{(d)}$

7

$\pm .0067$

$\pm 0.44$

0.014

$\pm 57$

5

0.307
0.306
0.294
2

$\begin{array}{cr}0.0845 \cup & 8.63 \\ 0.0845 \cup & 8.27 \\ 0.142 & 7.96 \\ \text { NA } & 4\end{array}$$$
15
$$$$
24^{(e)}
$$$$
51
$$$$
\begin{array}{lll}
11 & 15
\end{array}
$$

$0.264 \quad 0.434$

$0.237 \quad 0.356$

$0.232 \quad 0.295$

$\begin{array}{rr}1.08 & 51.9 \\ 1.02 & 52.7 \\ 1.23 & 51.6 \\ 10 & 1\end{array}$


Table G.3. (contd)

\begin{tabular}{|c|c|c|c|c|c|c|c|c|c|c|c|c|}
\hline \multirow[b]{2}{*}{$\begin{array}{l}\text { Sediment } \\
\text { Treatment }\end{array}$} & \multirow[b]{2}{*}{ Replicate } & \multirow[b]{2}{*}{$\begin{array}{l}\text { Analytical } \\
\text { Replicate }\end{array}$} & & \multicolumn{9}{|c|}{ Concentration (mg/kg dry wt) Blank Corrected } \\
\hline & & & & $\begin{array}{c}\mathrm{Ag} \\
\text { ICP/MS } \\
\end{array}$ & $\begin{array}{c}\text { As } \\
\text { ICP/MS }\end{array}$ & $\begin{array}{c}\mathrm{Cd} \\
\mathrm{ICP} / \mathrm{MS} \\
\end{array}$ & $\begin{array}{c}\mathrm{Cr} \\
\text { ICP/MS } \\
\end{array}$ & $\begin{array}{c}\mathrm{Cu} \\
\text { ICP/MS }\end{array}$ & $\begin{array}{c}\mathrm{Hg} \\
\text { CVAA } \\
\end{array}$ & $\begin{array}{c}\mathrm{Ni} \\
\text { ICP/MS } \\
\end{array}$ & $\begin{array}{c}\mathrm{Pb} \\
\text { ICP/MS } \\
\end{array}$ & $\begin{array}{c}\mathrm{Zn} \\
\text { ICP/MS } \\
\end{array}$ \\
\hline$B X C O M P^{(b)}$ & 1 & 1 & 1 & $0.22 \cup$ & 13.3 & 0.423 & $0.0845 \mathrm{U}$ & 7.55 & 0.217 & 0.427 & 1.36 & 50.5 \\
\hline$B \times$ COMP & 1 & 2 & 1 & $0.22 \mathrm{U}$ & 12.6 & 0.386 & $0.0845 \mathrm{U}$ & 7.15 & 0.209 & 0.320 & 1.31 & 48.5 \\
\hline$B X$ COMP & 1 & 3 & 1 & $0.22 \mathrm{U}$ & 13.6 & 0.422 & $0.0845 \mathrm{U}$ & 7.57 & 0.222 & 0.414 & 1.44 & 51.2 \\
\hline RSD (\%) & & & & NA & 4 & 5 & NA & 3 & 3 & 15 & 5 & 3 \\
\hline Nereis Bkgd. Tissue & 1 & 1 & 1 & $0.22 \mathrm{U}$ & 20.6 & 0.462 & 0.122 & 9.05 & 0.137 & 0.637 & 0.873 & 55.1 \\
\hline Nereis Bkgd. Tissue & 1 & 2 & 1 & $0.22 \cup$ & 16.1 & 0.437 & 0.135 & 8.08 & 0.225 & 0.492 & 1.01 & 54.7 \\
\hline Nereis Bkgd. Tissue & 1 & 3 & 1 & $0.22 \mathrm{U}$ & 17.6 & 0.530 & 0.137 & 7.82 & 0.228 & 0.505 & 0.87 & 54.7 \\
\hline RSD (\%) & & & & NA & 13 & 10 & 6 & 8 & $26^{(t)}$ & 15 & 9 & 0 \\
\hline
\end{tabular}

(a) U Undetected at or above given concentration.

(b) Sample randomly selected for use as a quality control sample in analytical batch.

(c) Outside quality control criteria $(75-125 \%)$ for spike recovery.

$Q$ (d) NA Not applicable.

$\rightarrow \quad$ (e) Outside SRM quality control criteria $(\leq 20 \%)$.

(f) Outside quality control criteria $(\leq 20 \%)$ for replicate analysis. 
Table G.4. Pesticides and Polychlorinated Biphenyls (PCBs) in N. virens Tissue (Wet Weight), Bronx River

\begin{tabular}{|c|c|c|c|c|c|}
\hline \multirow[b]{2}{*}{ Sediment Treatment } & \multicolumn{5}{|c|}{ Concentration ( $\mu \mathrm{g} / \mathrm{kg}$ wet $\mathrm{w} t)$} \\
\hline & $\mathrm{BX}$ COMP & BX COMP & BX COMP & BX COMP & BX COMP \\
\hline Replicate & 1 & 2 & 3 & 4 & 5 \\
\hline \multicolumn{6}{|l|}{ Analytical Replicate } \\
\hline Wet Weight (g) & 14.4 & 18.4 & 20.3 & 18.6 & 20.2 \\
\hline Percent Dry Wt. & 14.0 & 15.2 & 15.3 & 14.2 & 16.0 \\
\hline Batch & 2 & 1 & 1 & 1 & 1 \\
\hline $2,4^{\prime}-\mathrm{DDD}^{(a)}$ & 1.55 & 2.28 & 2.07 & 0.87 & 1.87 \\
\hline 2,4'-DDE & $0.37 U^{(b)}$ & $0.28 \mathrm{U}$ & $0.26 \mathrm{U}$ & $0.28 \mathrm{U}$ & $0.26 \mathrm{U}$ \\
\hline 2,4'-DDT & $0.25 \mathrm{U}$ & $0.19 \mathrm{U}$ & $0.18 \mathrm{U}$ & $0.19 \mathrm{U}$ & $0.18 \mathrm{U}$ \\
\hline $4,4^{\prime}-\mathrm{DDD}$ & 5.49 & 7.88 & 5.72 & 2.93 & 6.92 \\
\hline 4,4'-DDE & 2.65 & 4.07 & 3.46 & 1.76 & 3.47 \\
\hline $4,4^{\prime}-\mathrm{DDT}$ & 2.08 & 1.90 & 1.95 & 1.15 & 2.31 \\
\hline$\alpha$-Chlordane & 3.98 & 5.71 & 4.79 & 0.87 & 4.18 \\
\hline Aldrin & 2.52 & 3.36 & 3.01 & 1.42 & 3.07 \\
\hline Dieldrin & 2.92 & 3.75 & 3.06 & 1.39 & 3.28 \\
\hline Endosulfan I & $0.25 \mathrm{U}$ & $0.19 \mathrm{U}$ & $0.18 \mathrm{U}$ & $0.19 U$ & $0.18 \mathrm{U}$ \\
\hline Endosulfan II & $0.25 U$ & $0.19 u$ & $0.18 \mathrm{U}$ & $0.19 \mathrm{U}$ & $0.18 U$ \\
\hline Endosulfan Sulfate & $0.35 \mathrm{U}$ & $0.27 \mathrm{U}$ & $0.25 \mathrm{U}$ & $0.27 \mathrm{U}$ & $0.25 \mathrm{U}$ \\
\hline Heptachlor & $0.26 U$ & 0.60 & $0.18 \mathrm{U}$ & $0.20 \mathrm{U}$ & 0.37 \\
\hline Heptachlor Epoxide & $0.19 \mathrm{U}$ & 0.57 & 0.39 & $0.14 \mathrm{U}$ & 0.50 \\
\hline Trans Nonachlor & 2.55 & 2.73 & 2.43 & 1.28 & 3.34 \\
\hline PCB 8 & $0.49 U$ & $0.38 \mathrm{U}$ & $0.34 U$ & $0.38 \mathrm{U}$ & $0.34 \mathrm{U}$ \\
\hline РCB 18 & 10.8 & 15.9 & 13.7 & 2.08 & 12.0 \\
\hline PCB 28 & 7.04 & 9.72 & 8.68 & 1.19 & 8.06 \\
\hline PCB 44 & 9.05 & 7.84 & 7.03 & $0.08 \mathrm{U}$ & 5.91 \\
\hline PCB 49 & 6.44 & 7.36 & 6.33 & 2.40 & 6.46 \\
\hline РCB 52 & 11.0 & 12.1 & 11.0 & 4.48 & 10.6 \\
\hline PCB 66 & $0.21 \mathrm{U}$ & 7.40 & $0.15 \mathrm{U}$ & $0.16 \mathrm{U}$ & 6.86 \\
\hline PCB 87 & 0.68 & 1.01 & 0.77 & $0.27 \mathrm{U}$ & 0.89 \\
\hline PCB 101 & 6.24 & 6.22 & 5.99 & 3.06 & 6.25 \\
\hline PCB 105 & 1.91 & 1.69 & 1.72 & 1.07 & 1.78 \\
\hline PCB 118 & 3.86 & 3.63 & 3.46 & 1.81 & 3.74 \\
\hline PCB 128 & 0.71 & 0.69 & 0.74 & 0.45 & 0.77 \\
\hline PCB 138 & 6.01 & 4.72 & 5.02 & 2.53 & 5.20 \\
\hline PCB 153 & 7.40 & 6.55 & 7.30 & 3.40 & 7.01 \\
\hline PCB 170 & 1.51 & 1.60 & 1.65 & 0.57 & 1.66 \\
\hline PCB 180 & 3.12 & 3.02 & 3.12 & 1.07 & 3.35 \\
\hline PCB 183 & 0.83 & 0.86 & 0.99 & 0.26 & 1.01 \\
\hline PCB 184 & $0.26 \mathrm{U}$ & $0.20 \mathrm{U}$ & $0.18 \mathrm{U}$ & $0.20 \mathrm{U}$ & $0.18 \mathrm{U}$ \\
\hline PCB 187 & 2.17 & 2.18 & 2.49 & 0.85 & 2.37 \\
\hline PCB 195 & $0.18 \mathrm{U}$ & 0.22 & 0.23 & $0.14 \mathrm{U}$ & 0.19 \\
\hline PCB 206 & $0.30 \mathrm{U}$ & 0.27 & 0.33 & $0.23 \mathrm{U}$ & 0.29 \\
\hline PCB 209 & $0.27 \mathrm{U}$ & $0.21 \mathrm{U}$ & $0.19 \mathrm{U}$ & $0.21 \mathrm{U}$ & $0.19 \mathrm{U}$ \\
\hline \multicolumn{6}{|c|}{ Surrogate Recoveries (\%) } \\
\hline PCB 103 (SIS) & 85 & 102 & 67 & 99 & 114 \\
\hline PCB 198 (SIS) & 71 & 77 & 48 & 78 & 95 \\
\hline
\end{tabular}


Table G.4. (contd)

\begin{tabular}{|c|c|c|c|c|c|}
\hline \multirow{3}{*}{$\begin{array}{l}\text { Sediment Treatment } \\
\text { Replicate }\end{array}$} & \multicolumn{5}{|c|}{ Concentration ( $\mu \mathrm{g} / \mathrm{kg}$ wet $w \mathrm{t})$} \\
\hline & MDRS $^{(c)}$ & MDRS & MDRS & MDRS & MDRS \\
\hline & 1 & 2 & 3 & 4 & 4 \\
\hline Analytical Replicate & & & & 1 & 2 \\
\hline Wet Weight (g) & 20.2 & 20.4 & 20.0 & 12.9 & 12.1 \\
\hline Percent Dry Wt. & 16.2 & 13.9 & 13.8 & 18.9 & NA \\
\hline Batch & 1 & 1 & 2 & 1 & 1 \\
\hline 2,4'-DDD & 0.32 & $0.25 \mathrm{U}$ & $0.25 \mathrm{U}$ & $0.39 \mathrm{U}$ & $0.42 \mathrm{U}$ \\
\hline 2,4'-DDE & $0.26 \mathrm{U}$ & $0.26 \mathrm{U}$ & $0.26 \mathrm{U}$ & $0.40 \mathrm{U}$ & $0.43 \mathrm{U}$ \\
\hline 2,4'-DDT & $0.18 U$ & $0.18 \mathrm{U}$ & $0.18 \mathrm{U}$ & $0.28 \mathrm{U}$ & $0.29 \mathrm{U}$ \\
\hline 4,4-DDD & 1.15 & 1.19 & 0.78 & 1.00 & 1.26 \\
\hline 4,4'-DDE & 0.34 & 0.26 & $0.19 \mathrm{U}$ & 0.30 & $0.31 \mathrm{U}$ \\
\hline 4,4'-DDT & 1.03 & 0.76 & 0.67 & 0.40 & 0.73 \\
\hline$\alpha$-Chlordane & 0.28 & 0.16 & 0.10 & 0.19 & 0.19 \\
\hline Aldrin & 0.77 & 0.75 & 0.65 & 0.93 & 1.01 \\
\hline Dieldrin & $0.52 \mathrm{U}$ & $0.51 \mathrm{U}$ & $0.52 \mathrm{U}$ & $0.79 \mathrm{U}$ & $0.85 \mathrm{U}$ \\
\hline Endosulfan I & $0.18 \mathrm{U}$ & $0.18 \mathrm{U}$ & $0.18 \mathrm{U}$ & $0.28 \mathrm{U}$ & $0.30 \mathrm{U}$ \\
\hline Endosulfan II & $0.18 \mathrm{U}$ & $0.18 \mathrm{U}$ & $0.18 \mathrm{U}$ & $0.28 \mathrm{U}$ & $0.30 \mathrm{U}$ \\
\hline Endosulfan Sulfate & $0.25 \mathrm{U}$ & $0.25 U$ & $0.25 \mathrm{U}$ & $0.39 \mathrm{U}$ & $0.41 \mathrm{U}$ \\
\hline Heptachlor & $0.19 \mathrm{U}$ & $0.18 U$ & $0.19 \mathrm{U}$ & $0.28 \mathrm{U}$ & $0.30 \mathrm{U}$ \\
\hline Heptachlor Epoxide & $0.13 \mathrm{U}$ & $0.13 U$ & $0.13 U$ & $0.20 \mathrm{U}$ & $0.22 \mathrm{U}$ \\
\hline Trans Nonachlor & 0.69 & 0.35 & 0.47 & 0.31 & 0.32 \\
\hline PCB 8 & $0.35 \mathrm{U}$ & $0.34 \mathrm{U}$ & $0.35 \mathrm{U}$ & $0.54 \mathrm{U}$ & $0.58 \mathrm{U}$ \\
\hline РCB 18 & $0.10 \mathrm{U}$ & $0.10 \mathrm{U}$ & $0.10 \mathrm{U}$ & $0.16 \mathrm{U}$ & $0.17 \mathrm{U}$ \\
\hline РСB 28 & $0.11 \mathrm{U}$ & $0.11 \mathrm{U}$ & $0.11 \mathrm{U}$ & $0.17 \mathrm{U}$ & $0.18 \mathrm{U}$ \\
\hline PCB 44 & $0.07 \mathrm{U}$ & $0.07 \mathrm{U}$ & $0.07 \mathrm{U}$ & $0.11 \mathrm{U}$ & $0.12 \mathrm{U}$ \\
\hline PCB 49 & 0.65 & 0.44 & $0.18 \mathrm{U}$ & 0.57 & 0.54 \\
\hline PCB 52 & 1.45 & 1.24 & 0.97 & 1.07 & 1.01 \\
\hline PCB 66 & $0.15 \mathrm{U}$ & $0.15 \mathrm{U}$ & $0.15 \mathrm{U}$ & $0.23 \mathrm{U}$ & $0.25 \mathrm{U}$ \\
\hline PCB 87 & $0.25 U$ & $0.25 \mathrm{U}$ & $0.25 U$ & $0.39 \mathrm{U}$ & $0.41 \mathrm{U}$ \\
\hline PCB 101 & 1.33 & 1.11 & 0.75 & 0.79 & 0.70 \\
\hline PCB 105 & $0.17 \mathrm{U}$ & 0.60 & $0.17 \mathrm{U}$ & $0.26 \mathrm{U}$ & $0.27 \mathrm{U}$ \\
\hline РCB 118 & 0.65 & $0.19 \mathrm{U}$ & $0.19 \mathrm{U}$ & $0.29 \mathrm{U}$ & 0.37 \\
\hline PCB 128 & 0.25 & 0.23 & 0.17 & $0.16 \mathrm{U}$ & $0.17 \mathrm{U}$ \\
\hline PCB 138 & 1.50 & 1.55 & 0.98 & 0.65 & 0.67 \\
\hline PCB 153 & 2.10 & 2.21 & 1.47 & 0.86 & 0.92 \\
\hline PCB 170 & 0.41 & $0.17 U$ & 0.23 & $0.27 \mathrm{U}$ & $0.29 \mathrm{U}$ \\
\hline PCB 180 & 0.75 & 0.65 & 0.44 & $0.58 \mathrm{U}$ & $0.62 \mathrm{U}$ \\
\hline PCB 183 & 0.19 & $0.18 U$ & $0.18 \mathrm{U}$ & $0.28 \mathrm{U}$ & $0.30 \mathrm{U}$ \\
\hline PCB 184 & $0.18 \mathrm{U}$ & $0.18 \mathrm{U}$ & $0.18 \mathrm{U}$ & $0.28 \mathrm{U}$ & $0.30 \mathrm{U}$ \\
\hline PCB 187 & 0.52 & 0.58 & 0.24 & $0.32 \mathrm{U}$ & $0.34 \mathrm{U}$ \\
\hline PCB 195 & $0.13 \mathrm{U}$ & $0.12 U$ & $0.13 \mathrm{U}$ & $0.20 \mathrm{U}$ & $0.21 \mathrm{U}$ \\
\hline PCB 206 & $0.21 U$ & $0.21 \mathrm{U}$ & $0.21 \mathrm{U}$ & $0.33 \mathrm{U}$ & $0.35 \mathrm{U}$ \\
\hline РCB 209 & $0.20 \mathrm{U}$ & $0.19 \mathrm{U}$ & $0.20 \mathrm{U}$ & $0.30 \mathrm{U}$ & $0.32 \mathrm{U}$ \\
\hline \multicolumn{6}{|c|}{ Surrogate Recoveries (\%) } \\
\hline PCB 103 (SIS) & 105 & 59 & 123 & 107 & 109 \\
\hline PCB 198 (SIS) & 91 & 47 & 103 & 95 & 96 \\
\hline
\end{tabular}


Table G.4. (contd)

Concentration ( $\mu \mathrm{g} / \mathrm{kg}$ wet wt)

\begin{tabular}{|c|c|c|c|c|c|}
\hline \multirow[b]{2}{*}{$\begin{array}{l}\text { Sediment Treatment } \\
\text { Replicate }\end{array}$} & \\
\hline & $\begin{array}{c}\text { MDRS } \\
4\end{array}$ & $\begin{array}{c}\text { MDRS } \\
5\end{array}$ & $\begin{array}{c}\text { Nereis Bkgd. } \\
\text { Tissue }\end{array}$ & $\begin{array}{c}\text { Nereis Bkgd. } \\
\text { Tissue }\end{array}$ & $\begin{array}{c}\text { Nereis Bkgd. } \\
\text { Tissue }\end{array}$ \\
\hline Analytical Replicate & 3 & & 1 & 2 & 3 \\
\hline Wet Weight (g) & 12.3 & 20.1 & 20.4 & 20.0 & 20.5 \\
\hline Percent Dry Wt. & NA & 15.0 & 17.4 & 17.4 & 17.4 \\
\hline Batch & 1 & 1 & 2 & 2 & 2 \\
\hline 2,4'-DDD & $0.41 \mathrm{U}$ & $0.25 \mathrm{U}$ & $0.25 \mathrm{U}$ & $0.25 U$ & $0.25 \mathrm{U}$ \\
\hline $2,4^{\prime}-D D E$ & $0.42 \mathrm{U}$ & $0.26 \mathrm{U}$ & $0.26 \mathrm{U}$ & $0.26 \mathrm{U}$ & $0.26 \mathrm{U}$ \\
\hline 2,4'-DDT & $0.29 \mathrm{U}$ & $0.18 \mathrm{U}$ & $0.18 \mathrm{U}$ & $0.18 \mathrm{U}$ & $0.18 \mathrm{U}$ \\
\hline 4,4'-DDD & 1.04 & 0.99 & $0.26 \mathrm{U}$ & $0.26 U$ & $0.26 \mathrm{U}$ \\
\hline 4,4'-DDE & $0.30 \mathrm{U}$ & 0.21 & $0.18 \mathrm{U}$ & $0.19 \mathrm{U}$ & $0.18 \mathrm{U}$ \\
\hline 4,4'-DDT & 0.63 & 0.85 & 0.68 & 0.48 & 0.53 \\
\hline$\alpha$-Chlordane & 0.18 & 0.17 & $0.09 \mathrm{U}$ & $0.10 \mathrm{U}$ & $0.09 \mathrm{U}$ \\
\hline Aldrin & 0.99 & 0.70 & 0.46 & 0.47 & 0.47 \\
\hline Dieldrin & $0.84 \mathrm{U}$ & $0.52 \mathrm{U}$ & $0.51 \mathrm{U}$ & $0.52 \mathrm{U}$ & $0.51 \mathrm{U}$ \\
\hline Endosulfan I & $0.29 \mathrm{U}$ & $0.18 \mathrm{U}$ & $0.18 \mathrm{U}$ & $0.18 \mathrm{U}$ & $0.18 \mathrm{U}$ \\
\hline Endosulfan II & $0.29 \mathrm{U}$ & $0.18 \mathrm{U}$ & $0.18 \mathrm{U}$ & $0.18 \mathrm{U}$ & $0.18 \mathrm{U}$ \\
\hline Endosulfan Sulfate & $0.41 \mathrm{U}$ & $0.25 U$ & $0.25 \mathrm{U}$ & $0.25 \mathrm{U}$ & $0.25 \mathrm{U}$ \\
\hline Heptachlor & $0.30 \mathrm{U}$ & 1.00 & $0.18 U$ & $0.19 \mathrm{U}$ & $0.18 \mathrm{U}$ \\
\hline Heptachlor Epoxide & $0.22 \mathrm{U}$ & $0.13 \mathrm{U}$ & $0.13 U$ & $0.13 U$ & $0.13 \mathrm{U}$ \\
\hline Trans Nonachlor & $0.24 \mathrm{U}$ & 0.59 & 0.35 & $0.15 U$ & 0.32 \\
\hline PCB 8 & $0.57 \mathrm{U}$ & $0.35 U$ & $0.34 U$ & $0.35 \mathrm{U}$ & $0.34 \mathrm{U}$ \\
\hline PCB 18 & $0.17 \cup$ & 1.33 & $0.10 \mathrm{U}$ & $0.10 \mathrm{U}$ & $0.10 \mathrm{U}$ \\
\hline PCB 28 & $0.18 \mathrm{U}$ & $0.11 \mathrm{U}$ & $0.11 \mathrm{U}$ & $0.11 U$ & $0.11 \mathrm{U}$ \\
\hline PCB 44 & $0.11 \mathrm{U}$ & $0.07 \mathrm{U}$ & $0.07 \mathrm{U}$ & $0.07 \mathrm{U}$ & $0.07 \mathrm{U}$ \\
\hline PCB 49 & 0.48 & $0.18 \mathrm{U}$ & $0.18 \mathrm{U}$ & $0.18 \mathrm{U}$ & $0.18 U$ \\
\hline PCB 52 & 0.97 & 0.93 & $0.32 U$ & $0.32 \mathrm{U}$ & $0.32 U$ \\
\hline PCB 66 & $0.24 U$ & $0.15 \mathrm{U}$ & $0.15 \mathrm{U}$ & $0.15 \mathrm{U}$ & $0.15 \mathrm{U}$ \\
\hline PCB 87 & $0.41 \mathrm{U}$ & $0.25 \mathrm{U}$ & $0.25 \mathrm{U}$ & $0.25 \mathrm{U}$ & $0.25 \mathrm{U}$ \\
\hline РCB 101 & 0.64 & 0.90 & 0.19 & 0.18 & 0.19 \\
\hline PCB 105 & $0.27 \mathrm{U}$ & $0.17 \mathrm{U}$ & $0.16 U$ & $0.17 \mathrm{U}$ & $0.16 \mathrm{U}$ \\
\hline PCB 118 & $0.31 \mathrm{U}$ & $0.19 \mathrm{U}$ & $0.19 \mathrm{U}$ & $0.19 \mathrm{U}$ & $0.19 \mathrm{U}$ \\
\hline PCB 128 & $0.17 \mathrm{U}$ & 0.22 & 0.11 & 0.11 & 0.11 \\
\hline PCB 138 & 0.65 & 1.36 & 0.67 & 0.65 & 0.68 \\
\hline РCB 153 & 0.85 & 1.92 & 0.98 & 0.94 & 0.96 \\
\hline PCB 170 & $0.28 \mathrm{U}$ & 0.35 & $0.17 U$ & $0.18 \mathrm{U}$ & $0.17 \mathrm{U}$ \\
\hline PCB 180 & $0.61 \mathrm{U}$ & 0.66 & $0.37 \mathrm{U}$ & $0.38 \mathrm{U}$ & $0.37 \mathrm{U}$ \\
\hline PCB 183 & $0.30 \mathrm{U}$ & $0.18 \mathrm{U}$ & $0.18 \mathrm{U}$ & $0.18 \mathrm{U}$ & $0.18 \mathrm{U}$ \\
\hline PCB 184 & $0.30 \mathrm{U}$ & $0.18 \mathrm{U}$ & $0.18 \mathrm{U}$ & $0.18 \mathrm{U}$ & $0.18 \mathrm{U}$ \\
\hline PCB 187 & $0.33 U$ & 0.50 & $0.20 \mathrm{U}$ & $0.21 \mathrm{U}$ & $0.20 \mathrm{U}$ \\
\hline PCB 195 & $0.21 \mathrm{U}$ & $0.13 \mathrm{U}$ & $0.12 \mathrm{U}$ & $0.13 U$ & $0.12 \mathrm{U}$ \\
\hline PCB 206 & $0.35 \mathrm{U}$ & $0.21 \mathrm{U}$ & $0.21 \mathrm{U}$ & $0.21 \mathrm{U}$ & $0.21 \mathrm{U}$ \\
\hline PCB 209 & $0.32 \mathrm{U}$ & $0.20 \mathrm{U}$ & $0.19 \mathrm{U}$ & $0.20 \mathrm{U}$ & $0.19 \mathrm{U}$ \\
\hline \multicolumn{6}{|c|}{ Surrogate Recoveries (\%) } \\
\hline PCB 103 (SIS) & 109 & 110 & 124 & 103 & 130 \\
\hline PCB 198 (SIS) & 91 & 89 & 98 & 82 & 100 \\
\hline
\end{tabular}


Table G.5. Pesticides and Polychlorinated Biphenyls (PCBs) in N. virens Tissue (Dry Weight), Bronx River

Concentration ( $\mu \mathrm{g} / \mathrm{kg}$ dry wt)

\begin{tabular}{|c|c|c|c|c|c|}
\hline Sediment Treatment & BX COMP & BX COMP & BX COMP & BX COMP & BX COMP \\
\hline Replicate & 1 & 2 & 3 & 4 & 5 \\
\hline Analytical Replicate & 1 & 1 & 1 & 1 & 1 \\
\hline Wet Weight (g) & 14.4 & 18.4 & 20.3 & 18.6 & 20.2 \\
\hline Percent Dry Wt. & 14.0 & 15.2 & 15.3 & 14.2 & 16.0 \\
\hline Batch & 2 & 1 & 1 & 1 & 1 \\
\hline 2,4'-DDD & 11.1 & 15.0 & 13.6 & 6.1 & 11.7 \\
\hline 2,4'-DDE & $2.6 U^{(a)}$ & $1.8 \mathrm{U}$ & $1.7 \mathrm{U}$ & $2.0 \mathrm{U}$ & $1.6 \mathrm{U}$ \\
\hline 2,4'-DDT & $1.8 \mathrm{U}$ & $1.2 \mathrm{U}$ & $1.2 \mathrm{U}$ & $1.3 \mathrm{U}$ & $1.1 \mathrm{U}$ \\
\hline 4,4'-DDD & 39.2 & 51.7 & 37.5 & 20.6 & 43.4 \\
\hline 4,4'-DDE & 18.9 & 26.7 & 22.7 & 12.4 & 21.7 \\
\hline 4,4'-DDT & 14.9 & 12.5 & 12.8 & 8.09 & 14.5 \\
\hline$\alpha$-Chlordane & 28.4 & 37.5 & 31.4 & 6.1 & 26.2 \\
\hline Aldrin & 18.0 & 22.1 & 19.7 & 10.0 & 19.2 \\
\hline Dieldrin & 20.9 & 24.6 & 20.1 & $9.8 \mathrm{U}$ & 20.6 \\
\hline Endosulfan I & $1.8 \mathrm{U}$ & $1.2 \mathrm{U}$ & $1.2 \mathrm{U}$ & $1.3 \mathrm{U}$ & $1.1 \mathrm{U}$ \\
\hline Endosulfan II & $1.8 \mathrm{U}$ & $1.2 \mathrm{U}$ & $1.2 \mathrm{U}$ & $1.3 \mathrm{U}$ & $1.1 \mathrm{U}$ \\
\hline Endosulfan Sulfate & $2.5 \mathrm{U}$ & $1.8 \mathrm{U}$ & $1.6 \mathrm{U}$ & $1.9 \mathrm{U}$ & $1.6 \mathrm{U}$ \\
\hline Heptachlor & $1.9 \mathrm{U}$ & 3.9 & $1.2 \mathrm{U}$ & $1.4 \mathrm{U}$ & 2.3 \\
\hline Heptachlor Epoxide & $1.4 \mathrm{U}$ & 3.7 & 2.6 & $1.0 \mathrm{U}$ & 3.1 \\
\hline Trans Nonachlor & 18.2 & 17.9 & 15.9 & 9.00 & 20.9 \\
\hline РСB 8 & $3.5 \mathrm{U}$ & $2.5 \mathrm{U}$ & $2.2 \mathrm{U}$ & $2.7 \mathrm{U}$ & $2.1 \mathrm{U}$ \\
\hline PCB 18 & 77.1 & 104 & 89.8 & 14.6 & 75.0 \\
\hline РСВ 28 & 50.3 & 63.8 & 56.9 & $8.37 \mathrm{U}$ & 50.5 \\
\hline PCB 44 & 64.7 & 51.5 & 46.1 & $0.6 \mathrm{U}$ & 37.0 \\
\hline РСB 49 & 46.0 & 48.3 & 41.5 & 16.9 & 40.5 \\
\hline PCB 52 & 78.7 & 79.3 & 71.8 & 31.5 & 66.7 \\
\hline РCB 66 & $1.5 \mathrm{U}$ & 48.6 & $1.0 \mathrm{U}$ & $1.1 \mathrm{U}$ & 43.0 \\
\hline РCB 87 & 4.9 & 6.63 & 5.0 & $1.9 \mathrm{U}$ & 5.6 \\
\hline PCB 101 & 44.6 & 40.8 & 39.3 & 21.5 & 39.2 \\
\hline PCB 105 & 13.7 & 11.1 & 11.3 & 7.52 & 11.2 \\
\hline PCB 118 & 27.6 & 23.8 & 22.7 & 12.7 & 23.4 \\
\hline РCB 128 & 5.1 & 4.5 & 4.8 & 3.2 & 4.8 \\
\hline PCB 138 & 43.0 & 31.0 & 32.9 & 17.8 & 32.6 \\
\hline PCB 153 & 52.9 & 43.0 & 47.8 & 23.9 & 43.9 \\
\hline PCB 170 & 10.8 & 10.5 & 10.8 & 4.0 & 10.4 \\
\hline PCB 180 & 22.3 & 19.8 & 20.4 & 7.52 & 21.0 \\
\hline PCB 183 & 5.9 & 5.6 & 6.5 & 1.8 & 6.33 \\
\hline PCB 184 & $1.9 \mathrm{U}$ & $1.3 \mathrm{U}$ & $1.2 \mathrm{U}$ & $1.4 \mathrm{U}$ & $1.1 \mathrm{U}$ \\
\hline PCB 187 & 15.5 & 14.3 & 16.3 & 6.0 & 14.8 \\
\hline PCB 195 & $1.3 U$ & 1.4 & 1.5 & $1.0 \mathrm{U}$ & 1.2 \\
\hline PCB 206 & $2.1 \mathrm{U}$ & 1.8 & 2.2 & $1.6 \mathrm{U}$ & 1.8 \\
\hline PCB 209 & $1.9 \mathrm{U}$ & $1.4 \mathrm{U}$ & $1.2 \mathrm{U}$ & $1.5 \mathrm{U}$ & $1.2 \mathrm{U}$ \\
\hline
\end{tabular}


Table G.5. (contd)

Concentration ( $\mu \mathrm{g} / \mathrm{kg}$ dry $w \mathrm{t})$

\begin{tabular}{|c|c|c|c|c|c|}
\hline & & & & & \\
\hline Sediment Treatment & MDRS $^{(b)}$ & MDRS & MDRS & MDRS & MDRS \\
\hline Replicate & 1 & 2 & 3 & 4 & 4 \\
\hline Analytical Replicate & 1 & 1 & 1 & 1 & 2 \\
\hline Wet Weight (g) & 20.2 & 20.4 & 20.0 & 12.9 & 12.1 \\
\hline Percent Dry Wt. & 16.2 & 13.9 & 13.8 & 18.9 & 18.9 \\
\hline Batch & 1 & 1 & 2 & 1 & 1 \\
\hline 2,4'-DDD & 2.0 & $1.8 \mathrm{U}$ & $1.8 \mathrm{U}$ & $2.1 U$ & $2.2 \mathrm{U}$ \\
\hline 2,4'-DDE & $1.6 \mathrm{U}$ & $1.9 \mathrm{U}$ & $1.9 \mathrm{U}$ & $2.1 \mathrm{U}$ & $2.3 \mathrm{U}$ \\
\hline 2,4'-DDT & $1.1 \mathrm{U}$ & $1.3 \mathrm{U}$ & $1.3 \mathrm{U}$ & $1.5 \mathrm{U}$ & $1.5 \mathrm{U}$ \\
\hline 4,4'-DDD & 7.10 & 8.54 & $5.7 \mathrm{U}$ & 5.29 & 6.67 \\
\hline 4,4'-DDE & 2.1 & 1.9 & $1.4 \mathrm{U}$ & 1.6 & $1.6 \mathrm{U}$ \\
\hline 4,4'-DDT & 6.36 & 5.5 & 4.9 & 2.1 & 3.9 \\
\hline$\alpha$-Chlordane & 1.7 & 1.1 & 0.73 & 1.0 & 1.0 \\
\hline Aldrin & 4.8 & 5.4 & 4.7 & 4.9 & 5.3 \\
\hline Dieldrin & $3.2 \mathrm{U}$ & $3.7 \mathrm{U}$ & $3.8 \mathrm{U}$ & $4.2 \mathrm{U}$ & $4.5 \mathrm{U}$ \\
\hline Endosulfan I & $1.1 \mathrm{U}$ & $1.3 \mathrm{U}$ & $1.3 \mathrm{U}$ & $1.5 \mathrm{U}$ & $1.6 \mathrm{U}$ \\
\hline Endosulfan II & $1.1 \mathrm{U}$ & $1.3 \mathrm{U}$ & $1.3 \mathrm{U}$ & $1.5 \mathrm{U}$ & $1.6 \mathrm{U}$ \\
\hline Endosulfan Sulfate & $1.5 \mathrm{U}$ & $1.8 \mathrm{U}$ & $1.8 \mathrm{U}$ & $2.1 \mathrm{U}$ & $2.2 \mathrm{U}$ \\
\hline Heptachlor & $1.2 \mathrm{U}$ & $1.3 \mathrm{U}$ & $1.4 \mathrm{U}$ & $1.5 \mathrm{U}$ & $1.6 \mathrm{U}$ \\
\hline Heptachlor Epoxide & $0.80 \mathrm{U}$ & $0.93 \mathrm{U}$ & $0.94 \mathrm{U}$ & $1.1 \mathrm{U}$ & $1.2 \mathrm{U}$ \\
\hline Trans Nonachlor & 4.3 & 2.5 & 3.4 & 1.6 & 1.7 \\
\hline PCB 8 & $2.2 \mathrm{U}$ & $2.4 \mathrm{U}$ & $2.5 \mathrm{U}$ & $2.9 \mathrm{U}$ & $3.1 \mathrm{U}$ \\
\hline PCB 18 & $0.62 \mathrm{U}$ & $0.72 \mathrm{U}$ & $0.73 \mathrm{U}$ & $0.85 \mathrm{U}$ & $0.90 \mathrm{U}$ \\
\hline PCB 28 & $0.68 \mathrm{U}$ & $0.79 \mathrm{U}$ & $0.80 \mathrm{U}$ & $0.90 \mathrm{U}$ & $1.0 \mathrm{U}$ \\
\hline PCB 44 & $0.4 \mathrm{U}$ & $0.5 \mathrm{U}$ & $0.5 U$ & $0.58 \mathrm{U}$ & $0.64 \mathrm{U}$ \\
\hline PCB 49 & 4.0 & 3.2 & $1.3 \mathrm{U}$ & 3.0 & 2.9 \\
\hline PCB 52 & 8.95 & 8.90 & 7.0 & 5.66 & 5.35 \\
\hline PCB 66 & $0.93 \mathrm{U}$ & $1.1 \mathrm{U}$ & $1.1 \mathrm{U}$ & $1.2 \mathrm{U}$ & $1.3 \mathrm{U}$ \\
\hline PCB 87 & $1.5 \mathrm{U}$ & $1.8 \mathrm{U}$ & $1.8 \mathrm{U}$ & $2.1 \mathrm{U}$ & $2.2 \mathrm{U}$ \\
\hline PCB 101 & 8.21 & 7.97 & 5.4 & 4.2 & 3.7 \\
\hline PCB 105 & $1.0 \mathrm{U}$ & 4.3 & $1.2 \mathrm{U}$ & $1.4 \mathrm{U}$ & $1.4 \mathrm{U}$ \\
\hline PCB 118 & 4.0 & $1.4 \mathrm{U}$ & $1.4 \mathrm{U}$ & $1.5 \mathrm{U}$ & 2.0 \\
\hline PCB 128 & 1.5 & 1.7 & 1.2 & $0.85 \mathrm{U}$ & $0.90 \mathrm{U}$ \\
\hline PCB 138 & 9.26 & 11.1 & 7.1 & 3.4 & 3.5 \\
\hline PCB 153 & 13.0 & 15.9 & 10.7 & 4.6 & 4.9 \\
\hline PCB 170 & 2.5 & $1.2 \mathrm{U}$ & 1.7 & $1.4 \mathrm{U}$ & $1.5 \mathrm{U}$ \\
\hline PCB 180 & 4.6 & 4.7 & 3.2 & $3.1 \mathrm{U}$ & $3.3 \mathrm{U}$ \\
\hline PCB 183 & 1.2 & $1.3 \mathrm{U}$ & $1.3 \mathrm{U}$ & $1.5 \mathrm{U}$ & $1.6 \mathrm{U}$ \\
\hline PCB 184 & $1.1 \mathrm{U}$ & $1.3 \mathrm{U}$ & $1.3 \mathrm{U}$ & $1.5 \mathrm{U}$ & $1.6 \mathrm{U}$ \\
\hline PCB 187 & 3.2 & 4.2 & 1.7 & $1.7 \mathrm{U}$ & $1.8 \mathrm{U}$ \\
\hline PCB 195 & $0.80 \mathrm{U}$ & $0.86 \mathrm{U}$ & $0.94 \mathrm{U}$ & $1.1 \mathrm{U}$ & $1.1 \mathrm{U}$ \\
\hline PCB 206 & $1.3 \mathrm{U}$ & $1.5 \mathrm{U}$ & $1.5 \mathrm{U}$ & $1.7 \mathrm{U}$ & $1.9 \mathrm{U}$ \\
\hline PCB 209 & $1.2 \mathrm{U}$ & $1.4 U$ & $1.5 U$ & $1.6 \mathrm{U}$ & $1.7 \mathrm{U}$ \\
\hline
\end{tabular}


Table G.5. (contd)

Concentration ( $\mu \mathrm{g} / \mathrm{kg} \mathrm{dry} \omega \mathrm{t}$ )

\begin{tabular}{|c|c|c|c|c|c|}
\hline & & & & & \\
\hline $\begin{array}{l}\text { Sediment Treatment } \\
\text { Replicate }\end{array}$ & $\begin{array}{c}\text { MDRS } \\
4\end{array}$ & $\begin{array}{l}\text { MDRS } \\
5\end{array}$ & $\begin{array}{l}\text { Nereis Bkgd. } \\
\text { Tissue }\end{array}$ & $\begin{array}{l}\text { Nereis Bkgd. } \\
\text { Tissue }\end{array}$ & $\begin{array}{l}\text { Nereis Bkgd. } \\
\text { Tissue }\end{array}$ \\
\hline Analytical Replicate & 3 & 1 & 1 & 2 & 3 \\
\hline Wet Weight (g) & 12.3 & 20.1 & 20.4 & 20.0 & 20.5 \\
\hline Percent Dry Wt. & 18.9 & 15.0 & 17.4 & 17.4 & 17.4 \\
\hline Batch & 1 & 1 & 2 & 2 & 2 \\
\hline 2,4'-DDD & $2.2 \mathrm{U}$ & $1.7 \mathrm{U}$ & $1.4 \mathrm{U}$ & $1.4 \mathrm{U}$ & $1.4 \mathrm{U}$ \\
\hline 2,4'-DDE & $2.2 \mathrm{U}$ & $1.7 \mathrm{U}$ & $1.5 \mathrm{U}$ & $1.5 \mathrm{U}$ & $1.5 \mathrm{U}$ \\
\hline 2,4'-DDT & $1.5 \mathrm{U}$ & $1.2 \mathrm{U}$ & $1.0 \mathrm{U}$ & $1.0 \mathrm{U}$ & $1.0 \mathrm{U}$ \\
\hline 4,4'-DDD & 5.51 & 6.6 & $1.5 \mathrm{U}$ & $1.5 \mathrm{U}$ & $1.5 \mathrm{U}$ \\
\hline 4,4'-DDE & $1.6 \mathrm{U}$ & 1.4 & $1.0 \mathrm{U}$ & $1.1 \mathrm{U}$ & $1.0 \mathrm{U}$ \\
\hline 4,4'-DDT & 3.3 & 5.7 & 3.9 & 2.8 & 3.1 \\
\hline$\alpha$-Chlordane & 1.0 & 1.1 & $0.52 \mathrm{U}$ & $0.58 \mathrm{U}$ & $0.5 \mathrm{U}$ \\
\hline Aldrin & 5.2 & 4.7 & 2.7 & 2.7 & 2.7 \\
\hline Dieldrin & $4.4 \mathrm{U}$ & $3.5 \mathrm{U}$ & $2.9 \mathrm{U}$ & $3.0 \mathrm{U}$ & $2.9 \mathrm{U}$ \\
\hline Endosulfan I & $1.5 \mathrm{U}$ & $1.2 \mathrm{U}$ & $1.0 \mathrm{U}$ & $1.0 \mathrm{U}$ & $1.0 \mathrm{U}$ \\
\hline Endosulfan II & $1.5 \mathrm{U}$ & $1.2 \mathrm{U}$ & $1.0 \mathrm{U}$ & $1.0 \mathrm{U}$ & $1.0 \mathrm{U}$ \\
\hline Endosulfan Sulfate & $2.2 \mathrm{U}$ & $1.7 \mathrm{U}$ & $1.4 \mathrm{U}$ & $1.4 \mathrm{U}$ & $1.4 \mathrm{U}$ \\
\hline Heptachlor & $1.6 \mathrm{U}$ & 6.68 & $1.0 \mathrm{U}$ & $1.1 U$ & $1.0 \mathrm{U}$ \\
\hline Heptachlor Epoxide & $1.2 \mathrm{U}$ & $0.87 \mathrm{U}$ & $0.75 \mathrm{U}$ & $0.75 \mathrm{U}$ & $0.75 \mathrm{U}$ \\
\hline Trans Nonachlor & $1.3 \mathrm{U}$ & 3.9 & 2.0 & $0.86 \mathrm{U}$ & 1.8 \\
\hline РСВ 8 & $3.0 \mathrm{U}$ & $2.3 \mathrm{U}$ & $2.0 \mathrm{U}$ & $2.0 \mathrm{U}$ & $2.0 \mathrm{U}$ \\
\hline РСВ 18 & $0.90 \mathrm{U}$ & 8.88 & $0.6 \mathrm{U}$ & $0.6 \mathrm{U}$ & $0.58 \mathrm{U}$ \\
\hline РСВ 28 & $1.0 \mathrm{U}$ & $0.73 \mathrm{U}$ & $0.6 \mathrm{U}$ & $0.6 \mathrm{U}$ & $0.63 U$ \\
\hline РСB 44 & $0.58 \mathrm{U}$ & $0.5 \mathrm{U}$ & $0.4 \mathrm{U}$ & $0.4 \mathrm{U}$ & $0.4 \mathrm{U}$ \\
\hline РСB 49 & 2.5 & $1.2 \mathrm{U}$ & $1.0 \mathrm{U}$ & $1.0 \mathrm{U}$ & $1.0 \mathrm{U}$ \\
\hline РСВ 52 & 5.1 & 6.2 & $1.8 \mathrm{U}$ & $1.8 \mathrm{U}$ & $1.8 \mathrm{U}$ \\
\hline РСВ 66 & $1.3 \mathrm{U}$ & $1.0 \mathrm{U}$ & $0.9 \mathrm{U}$ & $0.9 \mathrm{U}$ & $0.86 U$ \\
\hline РСВ 87 & $2.2 U$ & $1.7 \mathrm{U}$ & $1.4 \mathrm{U}$ & $1.4 \mathrm{U}$ & $1.4 U$ \\
\hline PCB 101 & 3.4 & 6.0 & 1.1 & 1.0 & 1.1 \\
\hline PCB 105 & $1.4 \mathrm{U}$ & $1.1 \mathrm{U}$ & $0.92 \mathrm{U}$ & $1.0 \mathrm{U}$ & $0.92 \mathrm{U}$ \\
\hline PCB 118 & $1.6 \mathrm{U}$ & $1.3 \mathrm{U}$ & $1.1 \mathrm{U}$ & $1.1 \mathrm{U}$ & $1.1 \mathrm{U}$ \\
\hline PCB 128 & $0.90 \mathrm{U}$ & 1.5 & 0.6 & 0.63 & 0.63 \\
\hline PCB 138 & 3.4 & 9.08 & 3.9 & 3.7 & 3.9 \\
\hline PCB 153 & 4.5 & 12.8 & 5.6 & 5.4 & 5.5 \\
\hline PCB 170 & $1.5 \mathrm{U}$ & 2.3 & $1.0 \mathrm{U}$ & $1.0 \mathrm{U}$ & $1.0 \mathrm{U}$ \\
\hline PCB 180 & $3.2 \mathrm{U}$ & 4.4 & $2.1 \mathrm{U}$ & $2.2 \mathrm{U}$ & $2.1 \mathrm{U}$ \\
\hline PCB 183 & $1.6 \mathrm{U}$ & $1.2 \mathrm{U}$ & $1.0 \mathrm{U}$ & $1.0 \mathrm{U}$ & $1.0 \mathrm{U}$ \\
\hline РCB 184 & $1.6 \mathrm{U}$ & $1.2 \mathrm{U}$ & $1.0 \mathrm{U}$ & $1.0 \mathrm{U}$ & $1.0 \mathrm{U}$ \\
\hline РСB 187 & $1.7 \mathrm{U}$ & 3.3 & $1.2 U$ & $1.2 \mathrm{U}$ & $1.2 \mathrm{U}$ \\
\hline PCB 195 & $1.1 \mathrm{U}$ & $0.87 \mathrm{U}$ & $0.69 \mathrm{U}$ & $0.75 \mathrm{U}$ & $0.69 \mathrm{U}$ \\
\hline PCB 206 & $1.9 \mathrm{U}$ & $1.4 \mathrm{U}$ & $1.2 \mathrm{U}$ & $1.2 \mathrm{U}$ & $1.2 \mathrm{U}$ \\
\hline РCB 209 & $1.7 \mathrm{U}$ & $1.3 \mathrm{U}$ & $1.1 \mathrm{U}$ & $1.2 \mathrm{U}$ & $1.1 \mathrm{U}$ \\
\hline
\end{tabular}

(a) U Undetected at or above given concentration.

(b) MDRS Mud dump reference site. 
Table G.6. Quality Control Data for Pesticide and Polychlorinated Biphenyl (PCB) Analysis of $N$. virens Tissue (Wet Weight)

\begin{tabular}{|c|c|c|c|c|c|c|c|}
\hline \multirow{6}{*}{$\begin{array}{l}\text { Sediment Treatment } \\
\text { Replicate } \\
\text { Analytical Replicate } \\
\text { Wet Weight (g) } \\
\text { Batch }\end{array}$} & \multirow{6}{*}{$\begin{array}{c}\text { Blank } \\
1 \\
20.0 \\
1\end{array}$} & \multirow{6}{*}{$\begin{array}{c}\text { Blank } \\
1 \\
18.0 \\
2 \\
\end{array}$} & \multicolumn{5}{|c|}{ Matrix Spike Results } \\
\hline & & & \multicolumn{4}{|c|}{ Concentration ( $\mu \mathrm{g} / \mathrm{kg}$ wet weight) } & \multirow{5}{*}{$\begin{array}{l}\text { Percent } \\
\text { Recovery }\end{array}$} \\
\hline & & & $\begin{array}{c}\text { SR COMP }^{(a)} \\
3\end{array}$ & $\begin{array}{l}\text { SR COMP } \\
\text { (MS) }\end{array}$ & \multicolumn{2}{|c|}{ Concentration } & \\
\hline & & & 1 & 1 & Spiked & Recovered & \\
\hline & & & 13.2 & 13.1 & & & \\
\hline & & & 1 & 1 & & & \\
\hline 2,4'-DDD & $0.25 U^{60}$ & $0.28 \mathrm{U}$ & $0.39 \mathrm{U}$ & $0.39 \mathrm{U}$ & $N S^{(c)}$ & $N A^{(d)}$ & NA \\
\hline 2,4'-DDE & $0.26 \mathrm{U}$ & $0.29 \mathrm{U}$ & $0.40 \mathrm{U}$ & $0.40 \mathrm{U}$ & NS & NA & NA \\
\hline $2,4^{\prime}-\mathrm{DDT}$ & $0.18 \mathrm{U}$ & $0.20 \mathrm{U}$ & $0.27 \mathrm{U}$ & $0.27 \mathrm{U}$ & NS & NA & NA \\
\hline 4,4'-DDD & $0.26 \mathrm{U}$ & $0.29 \mathrm{U}$ & 1.05 & 4.45 & 3.80 & 3.40 & 89 \\
\hline 4,4'-DDE & $0.19 \mathrm{U}$ & $0.21 \mathrm{U}$ & 0.35 & 3.96 & 3.80 & 3.61 & 95 \\
\hline 4,4'-DDT & $0.15 \mathrm{U}$ & $0.17 \mathrm{U}$ & 0.89 & 4.63 & 3.80 & 3.74 & 98 \\
\hline$\alpha$-Chlordane & $0.10 \mathrm{U}$ & $0.11 \mathrm{U}$ & 0.23 & 3.92 & 3.80 & 3.69 & 97 \\
\hline Aldrin & 0.63 & $0.14 \mathrm{U}$ & 0.89 & 4.00 & 3.80 & 3.11 & 82 \\
\hline Dieldrin & $0.52 \mathrm{U}$ & $0.58 \mathrm{U}$ & $0.78 \mathrm{U}$ & 4.46 & 3.80 & 4.46 & 117 \\
\hline Endosulfan I & $0.18 \mathrm{U}$ & $0.20 \mathrm{U}$ & $0.27 \mathrm{U}$ & 3.12 & 3.80 & 3.12 & 82 \\
\hline Endosulfan II & $0.18 \mathrm{U}$ & $0.20 \mathrm{U}$ & $0.27 U$ & 3.51 & 3.80 & 3.51 & 92 \\
\hline Endosulfan Sulfate & $0.25 \mathrm{U}$ & $0.28 \mathrm{U}$ & $0.38 U$ & 4.15 & 3.80 & 4.15 & 109 \\
\hline Heptachlor & $0.19 U$ & $0.21 \mathrm{U}$ & $0.28 \mathrm{U}$ & 4.80 & 3.80 & 4.80 & $126^{(e)}$ \\
\hline Heptachlor Epoxide & $0.13 \mathrm{U}$ & $0.15 \mathrm{U}$ & $0.20 \mathrm{U}$ & 4.32 & 3.80 & 4.32 & 114 \\
\hline Trans Nonachlor & $0.15 \mathrm{U}$ & $0.16 \mathrm{U}$ & 0.51 & 0.49 & NS & NA & NA \\
\hline PCB 8 & $0.35 \mathrm{U}$ & $0.39 \mathrm{U}$ & $0.53 U$ & $0.53 \mathrm{U}$ & NS & NA & NA \\
\hline PCB 18 & $0.10 \mathrm{U}$ & $0.11 \mathrm{U}$ & $0.16 U$ & $0.16 \mathrm{U}$ & NS & NA & NA \\
\hline PCB 28 & $0.11 \mathrm{U}$ & $0.12 U$ & $0.17 \mathrm{U}$ & 4.86 & 4.84 & 4.86 & 100 \\
\hline PCB 44 & $0.07 \mathrm{U}$ & $0.08 \mathrm{U}$ & $0.11 \mathrm{U}$ & $0.11 \mathrm{U}$ & NS & NA & NA \\
\hline PCB 49 & $0.18 \mathrm{U}$ & $0.21 \mathrm{U}$ & 0.35 & 0.35 & NS & NA & NA \\
\hline PCB 52 & $0.32 \mathrm{U}$ & $0.36 \mathrm{U}$ & 0.91 & 12.4 & 10.1 & 11.5 & 114 \\
\hline PCB 66 & $0.15 \mathrm{U}$ & $0.17 \mathrm{U}$ & $0.23 \mathrm{U}$ & $0.23 \mathrm{U}$ & NS & NA & NA \\
\hline PCB 87 & $0.25 \mathrm{U}$ & $0.28 \mathrm{U}$ & $0.38 U$ & $0.38 \mathrm{U}$ & NS & NA & NA \\
\hline PCB 101 & $0.13 \mathrm{U}$ & $0.15 \mathrm{U}$ & 0.86 & 9.28 & 6.86 & 8.42 & $123^{\text {(e) }}$ \\
\hline PCB 105 & $0.17 \mathrm{U}$ & $0.19 \mathrm{U}$ & $0.25 U$ & $0.25 U$ & NS & NA & NA \\
\hline РСB 118 & $0.19 \mathrm{U}$ & $0.21 \mathrm{U}$ & 0.56 & 0.57 & NS & NA & NA \\
\hline PCB 128 & $0.11 \mathrm{U}$ & $0.12 \mathrm{U}$ & 0.20 & $0.16 \mathrm{U}$ & NS & NA & NA \\
\hline PCB 138 & $0.27 \mathrm{U}$ & $0.30 \mathrm{U}$ & 1.36 & 4.94 & 3.10 & 3.58 & 115 \\
\hline PCB 153 & $0.44 \mathrm{U}$ & $0.49 \mathrm{U}$ & 2.01 & 6.50 & 4.01 & 4.49 & 112 \\
\hline РСB 170 & $0.18 \mathrm{U}$ & $0.20 \mathrm{U}$ & 0.33 & $0.27 \mathrm{U}$ & NS & NA & NA \\
\hline PCB 180 & $0.38 \mathrm{U}$ & $0.42 \mathrm{U}$ & 0.66 & $0.57 \mathrm{U}$ & NS & NA & NA \\
\hline PCB 183 & $0.18 \mathrm{U}$ & $0.21 \mathrm{U}$ & $0.28 \mathrm{U}$ & $0.28 \mathrm{U}$ & NS & NA & NA \\
\hline PCB 184 & $0.18 \mathrm{U}$ & $0.21 \mathrm{U}$ & $0.28 U$ & $0.28 \mathrm{U}$ & NS & NA & NA \\
\hline PCB 187 & $0.21 \mathrm{U}$ & $0.23 \mathrm{U}$ & $0.31 \mathrm{U}$ & 0.36 & NS & NA & NA \\
\hline РСB 195 & $0.13 \mathrm{U}$ & $0.14 U$ & $0.19 \mathrm{U}$ & $0.19 \mathrm{U}$ & NS & NA & NA \\
\hline PCB 206 & $0.21 \mathrm{U}$ & $0.24 U$ & $0.33 \mathrm{U}$ & $0.33 \mathrm{U}$ & NS & NA & NA \\
\hline РCB 209 & $0.20 \mathrm{U}$ & $0.22 \mathrm{U}$ & $0.30 \mathrm{U}$ & $0.30 \mathrm{U}$ & NS & NA & NA \\
\hline \multicolumn{8}{|c|}{ Surrogate Recoveries (\%) } \\
\hline PCB 103 (SIS) & 90 & 82 & 104 & 104 & NA & NA & NA \\
\hline PCB 198 (SIS) & 82 & 81 & 93 & 105 & NA & NA & NA \\
\hline
\end{tabular}


Table G.6. (contd)

Matrix Spike Results

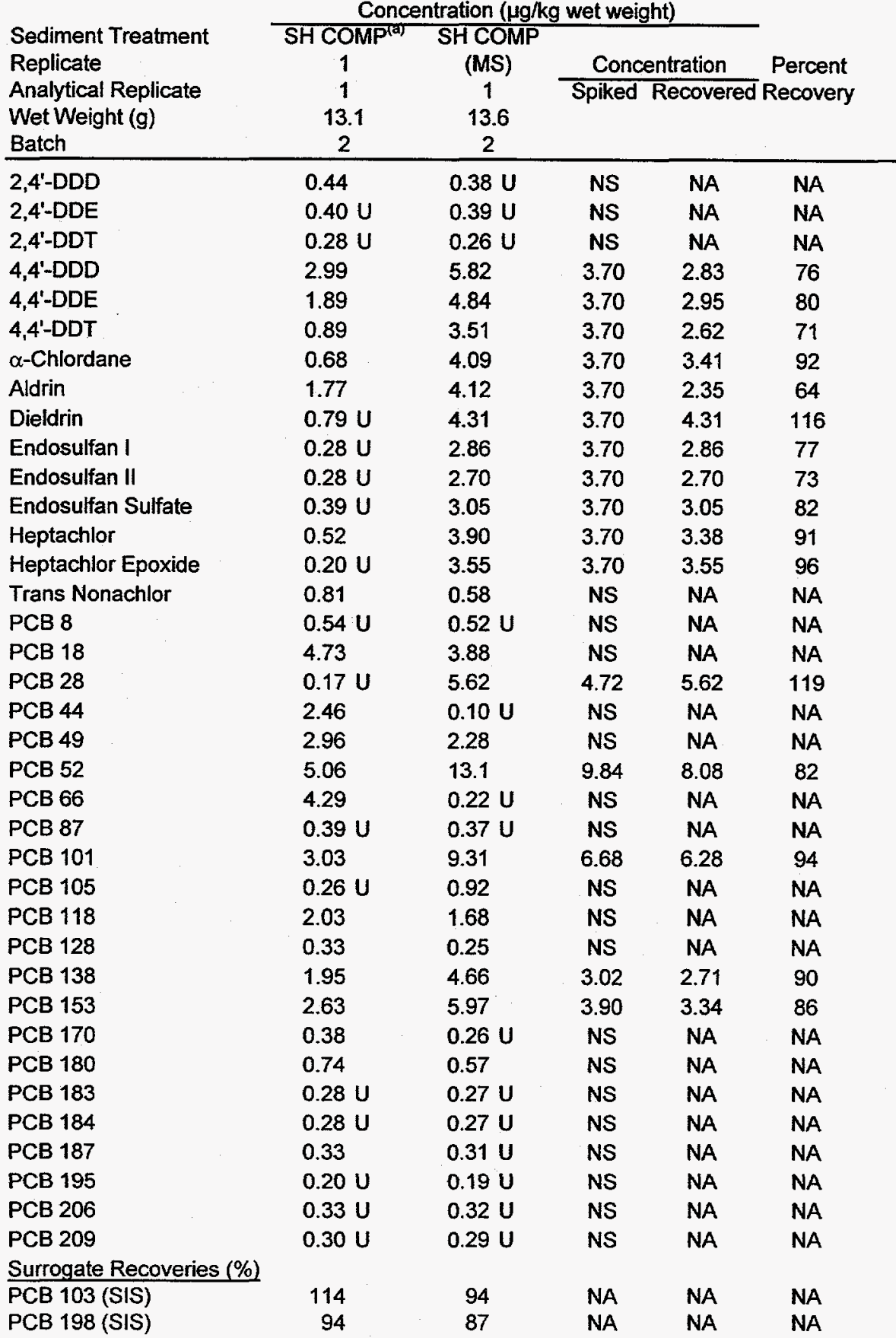


Table G.6. (contd)

Analytical Replicates

\begin{tabular}{|c|c|c|c|c|}
\hline \multirow{6}{*}{$\begin{array}{l}\text { Sediment Treatment } \\
\text { Replicate } \\
\text { Analytical Replicate } \\
\text { Wet Weight (g) } \\
\text { Batch } \\
\end{array}$} & \multicolumn{3}{|c|}{ Concentration ( $\mu \mathrm{g} / \mathrm{kg}$ wet weight) } & \multirow{6}{*}{$\begin{array}{c}\text { RSD } \\
(\%)\end{array}$} \\
\hline & MDRS & MDRS & MDRS & \\
\hline & 4 & 4 & 4 & \\
\hline & 1 & 2 & 3 & \\
\hline & 12.9 & 12.1 & 12.3 & \\
\hline & 1 & 1 & 1 & \\
\hline 2,4'-DDD & $0.39 \mathrm{U}$ & $0.42 \mathrm{U}$ & $0.41 \mathrm{U}$ & NA \\
\hline $2,4^{\prime}-\mathrm{DDE}$ & $0.40 \mathrm{U}$ & $0.43 \mathrm{U}$ & $0.42 \mathrm{U}$ & NA \\
\hline $2,4^{\prime}$-DDT & $0.28 \mathrm{U}$ & $0.29 u$ & $0.29 \mathrm{U}$ & NA \\
\hline $4,4^{\prime}-\mathrm{DDD}$ & 1.00 & 1.26 & 1.04 & 13 \\
\hline $4,4^{4}-\mathrm{DDE}$ & 0.30 & $0.31 \mathrm{U}$ & $0.30 \mathrm{U}$ & NA \\
\hline 4,4'-DDT & 0.40 & 0.73 & 0.63 & 29 \\
\hline$\alpha$-Chlordane & 0.19 & 0.19 & 0.18 & 3 \\
\hline Aldrin & 0.93 & 1.01 & 0.99 & 4 \\
\hline Dieldrin & $0.79 \mathrm{U}$ & $0.85 \mathrm{U}$ & $0.84 \mathrm{U}$ & NA \\
\hline Endosulfan I & $0.28 \mathrm{U}$ & $0.30 \mathrm{U}$ & $0.29 \mathrm{U}$ & NA \\
\hline Endosulfan II & $0.28 \mathrm{U}$ & $0.30 \mathrm{U}$ & $0.29 \mathrm{U}$ & NA \\
\hline Endosulfan Sulfate & $0.39 \mathrm{U}$ & $0.41 \mathrm{U}$ & $0.41 \mathrm{U}$ & NA \\
\hline Heptachlor & $0.28 \mathrm{U}$ & $0.30 \mathrm{U}$ & $0.30 \mathrm{U}$ & NA \\
\hline Heptachlor Epoxide & $0.20 \mathrm{U}$ & $0.22 \mathrm{U}$ & $0.22 \mathrm{U}$ & NA \\
\hline Trans Nonachlor & 0.31 & 0.32 & $0.24 \mathrm{U}$ & NA \\
\hline PCB 8 & $0.54 \mathrm{U}$ & $0.58 \mathrm{U}$ & $0.57 \mathrm{U}$ & NA \\
\hline РCB 18 & $0.16 \mathrm{U}$ & $0.17 \mathrm{U}$ & $0.17 \mathrm{U}$ & NA \\
\hline PCB 28 & $0.17 \mathrm{U}$ & $0.18 \mathrm{U}$ & $0.18 \mathrm{U}$ & NA \\
\hline PCB 44 & $0.11 \mathrm{U}$ & $0.12 \mathrm{U}$ & $0.11 \mathrm{U}$ & NA \\
\hline PCB 49 & 0.57 & 0.54 & 0.48 & 9 \\
\hline PCB 52 & 1.07 & 1.01 & 0.97 & 5 \\
\hline РСВ 66 & $0.23 \mathrm{U}$ & $0.25 \mathrm{U}$ & $0.24 \mathrm{U}$ & NA \\
\hline PCB 87 & $0.39 \mathrm{U}$ & $0.41 \mathrm{U}$ & $0.41 \mathrm{U}$ & NA \\
\hline PCB 101 & 0.79 & 0.70 & 0.64 & 11 \\
\hline PCB 105 & $0.26 \mathrm{U}$ & $0.27 \mathrm{U}$ & $0.27 \mathrm{U}$ & NA \\
\hline РСВ 118 & $0.29 \mathrm{U}$ & 0.37 & $0.31 \mathrm{U}$ & NA \\
\hline PCB 128 & $0.16 \mathrm{U}$ & $0.17 \mathrm{U}$ & $0.17 \mathrm{U}$ & NA \\
\hline PCB 138 & 0.65 & 0.67 & 0.65 & 2 \\
\hline PCB 153 & 0.86 & 0.92 & 0.85 & 4 \\
\hline PCB 170 & $0.27 \mathrm{U}$ & $0.29 \mathrm{U}$ & $0.28 \mathrm{U}$ & NA \\
\hline PCB 180 & $0.58 \mathrm{U}$ & $0.62 \mathrm{U}$ & $0.61 \mathrm{U}$ & NA \\
\hline PCB 183 & $0.28 \mathrm{U}$ & $0.30 \mathrm{U}$ & $0.30 \mathrm{U}$ & NA \\
\hline PCB 184 & $0.28 \mathrm{U}$ & $0.30 \mathrm{U}$ & $0.30 \mathrm{U}$ & NA \\
\hline PCB 187 & $0.32 \mathrm{U}$ & $0.34 \mathrm{U}$ & $0.33 \mathrm{U}$ & NA \\
\hline PCB 195 & $0.20 \mathrm{U}$ & $0.21 \mathrm{U}$ & $0.21 \mathrm{U}$ & NA \\
\hline PCB 206 & $0.33 \mathrm{U}$ & $0.35 \mathrm{U}$ & $0.35 \mathrm{U}$ & NA \\
\hline РCB 209 & $0.30 \mathrm{U}$ & $0.32 \mathrm{U}$ & $0.32 \mathrm{U}$ & NA \\
\hline \multicolumn{5}{|c|}{ Surrogate Recoveries (\%) } \\
\hline PCB 103 (SIS) & 107 & 109 & 109 & NA \\
\hline PCB 198 (SIS) & 95 & 96 & 91 & NA \\
\hline
\end{tabular}


Table G.6. (contd)

\begin{tabular}{|c|c|c|c|c|}
\hline \multirow[b]{3}{*}{$\begin{array}{l}\text { Sediment Treatment } \\
\text { Replicate } \\
\text { Analytical Replicate } \\
\text { Wet Weight }(g) \\
\text { Batch }\end{array}$} & \multicolumn{4}{|c|}{ Analytical Replicates } \\
\hline & \multicolumn{3}{|c|}{ Concentration ( $\mu \mathrm{g} / \mathrm{kg}$ wet weight) } & \multirow[b]{2}{*}{$\begin{array}{l}\text { RSD } \\
(\%)\end{array}$} \\
\hline & $\begin{array}{c}\text { Nereis Bkgd. } \\
\text { Tissue } \\
1 \\
20.4 \\
2 \\
\end{array}$ & $\begin{array}{c}\text { Nereis Bkgd. } \\
\text { Tissue } \\
2 \\
20.0 \\
2 \\
\end{array}$ & $\begin{array}{c}\text { Nereis Bkgd. } \\
\text { Tissue } \\
3 \\
20.5 \\
2\end{array}$ & \\
\hline 2,4'-DDD & $0.25 \mathrm{U}$ & $0.25 \mathrm{U}$ & $0.25 \mathrm{U}$ & NA \\
\hline 2,4'-DDE & $0.26 \mathrm{U}$ & $0.26 \mathrm{U}$ & $0.26 \mathrm{U}$ & NA \\
\hline 2,4'-DDT & $0.18 \mathrm{U}$ & $0.18 \mathrm{U}$ & $0.18 \mathrm{U}$ & NA \\
\hline 4,4'-DDD & $0.26 \mathrm{U}$ & $0.26 \mathrm{U}$ & $0.26 \mathrm{U}$ & NA \\
\hline 4,4'-DDE & $0.18 \mathrm{U}$ & $0.19 \mathrm{U}$ & $0.18 \mathrm{U}$ & NA \\
\hline 4,4'-DDT & 0.68 & 0.48 & 0.53 & 18 \\
\hline$\alpha$-Chlordane & $0.09 \mathrm{U}$ & $0.10 \mathrm{U}$ & $0.09 \mathrm{U}$ & NA \\
\hline Aldrin & 0.46 & 0.47 & 0.47 & 1 \\
\hline Dieldrin & $0.51 \mathrm{U}$ & $0.52 \mathrm{U}$ & $0.51 \mathrm{U}$ & NA \\
\hline Endosulfan I & $0.18 \mathrm{U}$ & $0.18 \mathrm{U}$ & $0.18 \mathrm{U}$ & NA \\
\hline Endosulfan II & $0.18 U$ & $0.18 \mathrm{U}$ & $0.18 \mathrm{U}$ & NA \\
\hline Endosulfan Sulfate & $0.25 \mathrm{U}$ & $0.25 \mathrm{U}$ & $0.25 \mathrm{U}$ & NA \\
\hline Heptachlor & $0.18 \mathrm{U}$ & $0.19 U$ & $0.18 \mathrm{U}$ & NA \\
\hline Heptachlor Epoxide & $0.13 \mathrm{U}$ & $0.13 U$ & $0.13 \mathrm{U}$ & NA \\
\hline Trans Nonachlor & 0.35 & $0.15 \mathrm{U}$ & 0.32 & NA \\
\hline PCB 8 & $0.34 \mathrm{U}$ & $0.35 \mathrm{U}$ & $0.34 \mathrm{U}$ & NA \\
\hline PCB 18 & $0.10 \mathrm{U}$ & $0.10 \mathrm{U}$ & $0.10 \mathrm{U}$ & NA \\
\hline PCB 28 & $0.11 \mathrm{U}$ & $0.11 \mathrm{U}$ & $0.11 \mathrm{U}$ & NA \\
\hline PCB 44 & $0.07 \mathrm{U}$ & $0.07 \mathrm{U}$ & $0.07 \mathrm{U}$ & NA \\
\hline PCB 49 & $0.18 \mathrm{U}$ & $0.18 \mathrm{U}$ & $0.18 \mathrm{U}$ & NA \\
\hline PCB 52 & $0.32 \mathrm{U}$ & $0.32 \mathrm{U}$ & $0.32 \mathrm{U}$ & NA \\
\hline РCB 66 & $0.15 U$ & $0.15 \mathrm{U}$ & $0.15 \mathrm{U}$ & NA \\
\hline PCB 87 & $0.25 \mathrm{U}$ & $0.25 \mathrm{U}$ & $0.25 \mathrm{U}$ & NA \\
\hline PCB 101 & 0.19 & 0.18 & 0.19 & 3 \\
\hline PCB 105 & $0.16 \mathrm{U}$ & $0.17 \mathrm{U}$ & $0.16 U$ & NA \\
\hline PCB 118 & $0.19 \mathrm{U}$ & $0.19 U$ & $0.19 \mathrm{U}$ & NA \\
\hline PCB 128 & 0.11 & 0.11 & 0.11 & 0 \\
\hline PCB 138 & 0.67 & 0.65 & 0.68 & 2 \\
\hline PCB 153 & 0.98 & 0.94 & 0.96 & 2 \\
\hline PCB 170 & $0.17 U$ & $0.18 \mathrm{U}$ & $0.17 \mathrm{U}$ & NA \\
\hline PCB 180 & $0.37 \mathrm{U}$ & $0.38 \mathrm{U}$ & $0.37 \mathrm{U}$ & NA \\
\hline PCB 183 & $0.18 \mathrm{U}$ & $0.18 \mathrm{U}$ & $0.18 \mathrm{U}$ & NA \\
\hline PCB 184 & $0.18 U$ & $0.18 U$ & $0.18 U$ & NA \\
\hline PCB 187 & $0.20 \mathrm{U}$ & $0.21 \mathrm{U}$ & $0.20 \mathrm{U}$ & NA \\
\hline PCB 195 & $0.12 U$ & $0.13 \mathrm{U}$ & $0.12 \mathrm{U}$ & NA \\
\hline PCB 206 & $0.21 \mathrm{U}$ & $0.21 \mathrm{U}$ & $0.21 \mathrm{U}$ & NA \\
\hline PCB 209 & $0.19 \mathrm{U}$ & $0.20 \mathrm{U}$ & $0.19 \mathrm{U}$ & NA \\
\hline \multicolumn{5}{|c|}{ Surrogate Recoveries (\%) } \\
\hline PCB 103 (SIS) & 124 & 103 & 130 & NA \\
\hline PCB 198 (SIS) & 98 & 82 & 100 & NA \\
\hline
\end{tabular}
(a) Sample randomly selected for use as a quality control sample in analytical batch
(b) U Undetected at or above given concentration.
(c) NS Not spiked.
(d) NA Not applicable.
(e) Outside quality control criteria (50-120\%) for spike recovery.
(f) MDRS Mud Dump Reference Site. 
Table G.7. Polynuclear Aromatic Hydrocarbons (PAHs) in N. virens Tissue (Wet Weight), Bronx River

Concentration $(\mu \mathrm{g} / \mathrm{kg}$ wet wt)

\begin{tabular}{lccccc} 
Sediment Treatment & BX COMP & BX COMP & BX COMP & BX COMP & BX COMP \\
\cline { 2 - 6 } Replicate & 1 & 2 & 3 & 4 & 5 \\
Analytical Replicate & 1 & 1 & 1 & 1 & 1 \\
Wet Weight (g) & 14.4 & 18.4 & 20.3 & 18.6 & 20.2 \\
Percent Dry Weight & 14.0 & 15.2 & 15.3 & 14.2 & 16.0 \\
Batch & 2 & 1 & 1 & 1 & 1 \\
\hline & & & & & \\
1,4-Dichlorobenzene (a) & $2.61 \mathrm{U}^{(\mathrm{b})}$ & $2.17 \mathrm{U}$ & $1.97 \mathrm{U}$ & $2.16 \mathrm{U}$ & $1.98 \mathrm{U}$ \\
Naphthalene & $2.61 \mathrm{U}$ & 4.27 & $4.94 \mathrm{~B}^{(\mathrm{c})}$ & 4.26 & $2.89 \mathrm{~B}$ \\
Acenaphthylene & 1.97 (d) & 0.85 & 0.87 & $0.59 \mathrm{U}$ & 0.77 \\
Acenaphthene & 4.08 & 5.10 & 5.34 & 3.58 & 4.46 \\
Fluorene & $2.55 \mathrm{~B}$ & 1.78 & 1.88 & $1.38 \mathrm{U}$ & $1.26 \mathrm{U}$ \\
Phenanthrene & $3.58 \mathrm{U}$ & 7.64 & 8.87 & $2.88 \mathrm{U}$ & 6.43 \\
Anthracene & $3.13 \mathrm{U}$ & $2.44 \mathrm{U}$ & 2.33 & $2.43 \mathrm{U}$ & $2.22 \mathrm{U}$ \\
Fluoranthene & 66.8 & 116 & 129 & 29.0 & 128 \\
Pyrene & 89.2 & 153 & 166 & 40.5 & 160 \\
Benzo[a]anthracene & $5.36 \mathrm{~B}$ & 10.3 & 14.2 & 1.53 & 10.7 \\
Chrysene & 33.8 & 52.0 & 54.6 & 9.23 & 61.1 \\
Benzo[b]fluoranthene & 8.60 & 10.1 & 13.1 & 1.87 & 13.0 \\
Benzo[k]fluoranthene & 4.90 & 4.47 & 5.79 & $1.62 \mathrm{U}$ & 6.72 \\
Benzo[a]pyrene & $3.74{ }^{(\mathrm{d})}$ & 5.51 & 7.04 & $1.38 \mathrm{U}$ & 8.19 \\
Indeno[123-cd]pyrene & $2.47 \mathrm{U}$ & $1.66 \mathrm{U}$ & 1.87 & $1.65 \mathrm{U}$ & 2.61 \\
Dibenzo[a,h]anthracene & $1.76 \mathrm{U}$ & $1.32 \mathrm{U}$ & $1.20 \mathrm{U}$ & $1.32 \mathrm{U}$ & $1.21 \mathrm{U}$ \\
Benzo[g,h,i]perylene & 3.31 & 2.68 & 2.91 & $1.15 \mathrm{U}$ & 4.96 \\
& & & & & \\
Surrogate Recoveries (\%) & & 59 & 32 & 59 & 68 \\
\hline d4 1,4-Dichlorobenzene & 38 & 68 & 39 & 65 & 75 \\
d8 Naphthalene & 46 & 81 & 49 & 77 & 92 \\
d10 Acenaphthene & 56 & 73 & 48 & 84 & 91 \\
d12 Chrysene & 61 & 98 & 58 & 98 & 121 \\
d14 Dibenzo[a,h]anthracen & 73 & & & & \\
& & & & & \\
\end{tabular}


Table G.7. (contd)

\begin{tabular}{|c|c|c|c|c|c|c|}
\hline \multirow[b]{2}{*}{ Sediment Treatment } & \multicolumn{6}{|c|}{ Concentration ( $\mu \mathrm{g} / \mathrm{kg}$ wet $w \mathrm{t})$} \\
\hline & MDRS $^{(\boldsymbol{\theta})}$ & MDRS & \multicolumn{2}{|c|}{ MDRS } & MDRS & MDRS \\
\hline Replicate & 1 & 2 & \multicolumn{2}{|c|}{3} & 4 & 4 \\
\hline Analytical Replicate & 1 & 1 & \multicolumn{2}{|l|}{1} & 1 & 2 \\
\hline Wet Weight (g) & 20.2 & 20.4 & \multicolumn{2}{|c|}{20.0} & 12.9 & 12.1 \\
\hline Percent Dry Weight & 16.2 & 13.9 & \multicolumn{2}{|c|}{13.8} & 18.9 & 18.9 \\
\hline Batch & 1 & 1 & \multicolumn{2}{|l|}{2} & 1 & 1 \\
\hline 1,4-Dichlorobenzene & $1.98 \mathrm{U}$ & $1.96 \mathrm{U}$ & 1.86 & $\mathbf{u}$ & $3.10 \mathrm{U}$ & $3.30 \mathrm{U}$ \\
\hline Naphthalene & $3.07 \mathrm{~B}$ & $5.84 \mathrm{~B}$ & 1.86 & $\mathbf{U}$ & $4.48 \mathrm{~B}$ & $4.70 \mathrm{~B}$ \\
\hline Acenaphthylene & $0.55 \mathrm{U}$ & $0.54 \mathrm{U}$ & 0.73 & $\mathbf{U}$ & $0.85 \mathrm{U}$ & $0.91 \mathrm{U}$ \\
\hline Acenaphthene & $1.38 \mathrm{U}$ & $1.36 \mathrm{U}$ & 1.30 & $\mathrm{u}$ & $2.15 \mathrm{U}$ & $2.29 \mathrm{U}$ \\
\hline Fluorene & $1.27 \mathrm{U}$ & $1.26 \mathrm{U}$ & 1.44 & B & $1.98 \mathrm{U}$ & $2.11 \mathrm{U}$ \\
\hline Phenanthrene & $2.65 \mathrm{U}$ & $2.62 U$ & 2.56 & u & $4.13 \mathrm{U}$ & $4.40 \mathrm{U}$ \\
\hline Anthracene & $2.23 \mathrm{U}$ & $2.21 \mathrm{U}$ & 2.24 & u & $3.48 \mathrm{U}$ & $3.71 \mathrm{U}$ \\
\hline Fluoranthene & $3.07 \mathrm{U}$ & $3.04 \mathrm{U}$ & 5.36 & $\mathbf{u}$ & $4.80 \mathrm{U}$ & $5.11 U$ \\
\hline Pyrene & 4.71 & $2.74 \mathrm{U}$ & 4.57 & $\mathbf{u}$ & 8.10 & 7.26 \\
\hline Benzo[a]anthracene & $0.89 U$ & $0.88 \mathrm{U}$ & 1.09 & u & 1.55 & $1.48 \mathrm{U}$ \\
\hline Chrysene & 1.86 & $1.71 \mathrm{U}$ & 2.27 & $\mathrm{u}$ & $2.69 \mathrm{U}$ & $2.87 \mathrm{U}$ \\
\hline Benzo[b]fluoranthene & $1.13 \mathrm{U}$ & $1.12 \mathrm{U}$ & 1.64 & $u$ & $1.76 \mathrm{U}$ & $1.88 \mathrm{U}$ \\
\hline Benzo[k]fluoranthene & $1.49 \mathrm{U}$ & $1.47 \mathrm{U}$ & 1.67 & $u$ & $2.32 \mathrm{U}$ & $2.47 \mathrm{U}$ \\
\hline Benzo[a]pyrene & $1.27 \mathrm{U}$ & $1.26 \mathrm{U}$ & 1.49 & u & $1.98 \mathrm{U}$ & $2.11 \mathrm{U}$ \\
\hline Indeno[123-cd]pyrene & $1.52 \mathrm{U}$ & $1.50 \mathrm{U}$ & 1.76 & u & $2.37 \mathrm{U}$ & $2.52 \mathrm{U}$ \\
\hline Dibenzo[a,h]anthracene & $1.21 \mathrm{U}$ & $1.20 \mathrm{U}$ & 1.26 & $\mathrm{u}$ & $1.89 \mathrm{U}$ & $2.01 \mathrm{U}$ \\
\hline Benzo[g,h,jperylene & $1.06 \mathrm{U}$ & $1.05 \mathrm{U}$ & 1.40 & $\mathbf{u}$ & $1.66 \mathrm{U}$ & $1.76 \mathrm{U}$ \\
\hline \multicolumn{7}{|l|}{ Surrogate Recoveries $(\%)$} \\
\hline d4 1,4-Dichlorobenzene & 53 & 33 & 74 & & 88 & 75 \\
\hline d8 Naphthalene & 62 & 35 & 84 & & 81 & 72 \\
\hline d10 Acenaphthene & 84 & 43 & 93 & & 91 & 90 \\
\hline d12 Chrysene & 82 & 46 & 95 & & 77 & 85 \\
\hline d14 Dibenzo[a,h]anthracene & 115 & 55 & 116 & & 125 & 123 \\
\hline
\end{tabular}


Table G.7. (contd)

Concentration ( $\mu \mathrm{g} / \mathrm{kg}$ wet wt)

\begin{tabular}{|c|c|c|c|c|c|}
\hline \multirow[b]{2}{*}{$\begin{array}{l}\text { Sediment Treatment } \\
\text { Replicate }\end{array}$} & \\
\hline & $\begin{array}{c}\text { MDRS } \\
4\end{array}$ & $\begin{array}{c}\text { MDRS } \\
5\end{array}$ & $\begin{array}{c}\text { Nereis Bkgd. } \\
\text { Tissue }\end{array}$ & $\begin{array}{c}\text { Nereis Bkgd. } \\
\text { Tissue }\end{array}$ & $\begin{array}{c}\text { Nereis Bkgd. } \\
\text { Tissue }\end{array}$ \\
\hline Analytical Replicate & 3 & 1 & 1 & 2 & 3 \\
\hline Wet Weight (g) & 12.3 & 20.1 & 20.4 & 20.0 & 20.5 \\
\hline Percent Dry Weight & 18.9 & 15.0 & 17.4 & 17.4 & 17.4 \\
\hline Batch & 1 & 1 & 2 & 2 & 2 \\
\hline 1,4-Dichlorobenzene & $3.26 \mathrm{U}$ & $1.99 U$ & $1.83 \mathrm{U}$ & $1.86 \mathrm{U}$ & $1.83 \mathrm{U}$ \\
\hline Naphthalene & $4.46 \mathrm{~B}$ & $2.96 \mathrm{~B}$ & $1.83 \mathrm{U}$ & $1.86 \mathrm{U}$ & $1.83 \mathrm{U}$ \\
\hline Acenaphthylene & $0.90 \mathrm{U}$ & $0.55 U$ & $0.71 U$ & $0.73 \mathrm{U}$ & $0.71 \mathrm{U}$ \\
\hline Acenaphthene & $2.27 \mathrm{U}$ & $1.38 \mathrm{U}$ & $1.28 \mathrm{U}$ & $1.30 \mathrm{U}$ & $1.28 \mathrm{U}$ \\
\hline Fluorene & $2.09 U$ & $1.27 \mathrm{U}$ & $1.86 \mathrm{~B}$ & $1.24 \mathrm{U}$ & $1.21 \mathrm{U}$ \\
\hline Phenanthrene & $4.35 \mathrm{U}$ & $2.66 \mathrm{U}$ & $2.51 \cup$ & $2.56 \cup$ & $2.51 \mathrm{U}$ \\
\hline Anthracene & $3.67 \mathrm{U}$ & $2.24 \mathrm{U}$ & $2.19 \mathrm{U}$ & $2.24 \mathrm{U}$ & $2.19 \mathrm{U}$ \\
\hline Fluoranthene & $5.05 \mathrm{U}$ & $3.08 \mathrm{U}$ & $5.26 U$ & $5.36 U$ & $5.26 U$ \\
\hline Pyrene & 6.16 & 3.19 & $4.48 \mathrm{U}$ & $4.57 \mathrm{U}$ & $4.48 \mathrm{U}$ \\
\hline Benzo[a]anthracene & 1.47 & 1.05 & $1.78 \mathrm{~B}$ & $1.53 \mathrm{~B}$ & $1.96 \mathrm{~B}$ \\
\hline Chrysene & $2.84 \mathrm{U}$ & $1.73 \mathrm{U}$ & $2.22 \mathrm{U}$ & $2.27 \cup$ & $2.22 \mathrm{U}$ \\
\hline Benzo[b]fluoranthene & $1.86 \mathrm{U}$ & $1.13 \mathrm{U}$ & $1.61 \mathrm{U}$ & $1.64 U$ & $1.61 \mathrm{U}$ \\
\hline Benzo[k]fluoranthene & $2.44 \mathrm{U}$ & $1.49 \mathrm{U}$ & $1.64 \mathrm{U}$ & $1.67 \mathrm{U}$ & $1.64 \mathrm{U}$ \\
\hline Benzo[a]pyrene & $2.09 \mathrm{U}$ & $1.27 \mathrm{U}$ & $1.46 \mathrm{U}$ & $1.49 \mathrm{U}$ & $1.46 \mathrm{U}$ \\
\hline Indeno[123-cd]pyrene & $2.49 \mathrm{U}$ & $1.52 \mathrm{U}$ & $1.73 \mathrm{U}$ & $1.76 \mathrm{U}$ & $1.73 \mathrm{U}$ \\
\hline Dibenzo[a,h]anthracene & $1.99 \mathrm{U}$ & $1.21 \mathrm{U}$ & $1.24 U$ & $1.26 \mathrm{U}$ & $1.24 \mathrm{U}$ \\
\hline Benzo[g,h,i]perylene & $1.74 \mathrm{U}$ & $1.06 \mathrm{U}$ & $1.37 \cup$ & $1.40 \mathrm{U}$ & $1.37 \mathrm{U}$ \\
\hline \multicolumn{6}{|l|}{ Surrogate Recoveries (\%) } \\
\hline d4 1,4-Dichlorobenzene & 78 & 73 & 55 & 45 & 63 \\
\hline d8 Naphthalene & 80 & 66 & 69 & 57 & 77 \\
\hline d10 Acenaphthene & 95 & 80 & 83 & 68 & 86 \\
\hline d12 Chrysene & 90 & 73 & 90 & 75 & 90 \\
\hline d14 Dibenzo[a,h]anthracene & 113 & 112 & 112 & 91 & 111 \\
\hline
\end{tabular}

(a) Target detection limits are $4.0 \mu \mathrm{g} / \mathrm{kg}$ for all analytes (except 1,4-Dichlorobenzene which is $0.4 \mu \mathrm{g} / \mathrm{kg}$ ).

(b) $U$ Undetected at or above given concentration.

(c) B Analyte detected in sample is $<5 x$ blank value.

(d) Ion ratio out or confirmation ion not detected.

(e) MDRS Mud dump reference site. 
Table G.8. Polynuclear Aromatic Hydrocarbons (PAHs) in N. virens Tissue (Dry Weight), Bronx River

\begin{tabular}{lccccc} 
& \multicolumn{5}{c}{ Concentration $(\mu \mathrm{g} / \mathrm{kg}$ dry wt) } \\
\cline { 2 - 6 } Sediment Treatment & BX COMP & BX COMP & BX COMP & BX COMP & BX COMP \\
Replicate & 1 & 2 & 3 & 4 & 5 \\
Analytical Replicate & 1 & 1 & 1 & 1 & 1 \\
Wet Weight (g) & 14.4 & 18.4 & 20.3 & 18.6 & 20.2 \\
Percent Dry Weight & 14.0 & 15.2 & 15.3 & 14.2 & 16.0 \\
Batch & 2 & 1 & 1 & 1 & 1 \\
\hline & & & & & \\
1,4-Dichlorobenzene & $18.7 \mathrm{U}$ & $14.2 \mathrm{U}$ & $12.9 \mathrm{U}$ & $15.2 \mathrm{U}$ & $12.4 \mathrm{U}$ \\
Naphthalene & $18.7 \mathrm{U}$ & 28.0 & $32.4 \mathrm{~B}$ & 30.0 & $18.1 \mathrm{~B}$ \\
Acenaphthylene & 14.1 (c) & 5.6 & 5.7 & $4.1 \mathrm{U}$ & 4.8 \\
Acenaphthene & 29.2 & 33.5 & 35.0 & 25.2 & 27.9 \\
Fluorene & $18.2 \mathrm{~B}$ & 11.7 & 12.3 & $9.70 \mathrm{U}$ & $7.89 \mathrm{U}$ \\
Phenanthrene & $25.6 \mathrm{U}$ & 50.2 & 58.1 & $20.3 \mathrm{U}$ & 40.3 \\
Anthracene & $22.4 \mathrm{U}$ & $16.0 \mathrm{U}$ & 15.3 & $17.1 \mathrm{U}$ & $13.9 \mathrm{U}$ \\
Fluoranthene & 477 & 759 & 847 & 204 & 802 \\
Pyrene & 638 & 1000 & 1090 & 285 & 1000 \\
Benzo[a]anthracene & $38.3 \mathrm{~B}$ & 67.4 & 92.7 & 10.8 & 67.0 \\
Chrysene & 241 & 342 & 358 & 64.9 & 383 \\
Benzo[b]fluoranthene & 61.5 & 66.3 & 85.8 & 13.2 & 81.5 \\
Benzo[k]fluoranthene & 35.0 & 29.3 & 37.9 & $11.4 \mathrm{U}$ & 42.1 \\
Benzo[a]pyrene & 26.7 (c) & 36.2 & 46.1 & $9.70 \mathrm{U}$ & 51.3 \\
Indeno[123-cd]pyrene & $17.7 \mathrm{U}$ & $10.9 \mathrm{U}$ & 12.3 & $11.6 \mathrm{U}$ & 16.4 \\
Dibenzo[a,h]anthracene & $12.6 \mathrm{U}$ & $8.67 \mathrm{U}$ & $7.86 \mathrm{U}$ & $9.28 \mathrm{U}$ & $7.58 \mathrm{U}$ \\
Benzo[g,h,i]perylene & 23.7 & 17.6 & 19.1 & $8.09 \mathrm{U}$ & 31.1 \\
& & & & & \\
& & & &
\end{tabular}


Table G.8. (contd)

\begin{tabular}{lccccc} 
& \multicolumn{5}{c}{ Concentration $(\mu \mathrm{kg} / \mathrm{kg}$ dry wt) } \\
\cline { 2 - 6 } Sediment Treatment & MDRS (d) & MDRS & MDRS & MDRS & MDRS \\
Replicate & 1 & 2 & 3 & 4 & 4 \\
Analytical Replicate & 1 & 1 & 1 & 1 & 2 \\
Wet Weight (g) & 20.2 & 20.4 & 20.0 & 12.9 & 12.1 \\
Percent Dry Weight & 16.2 & 13.9 & 13.8 & 18.9 & 18.9 \\
Batch & 1 & 1 & 2 & 1 & 1 \\
\hline & & & & & \\
1,4-Dichlorobenzene & $12.2 \mathrm{U}$ & $14.1 \mathrm{U}$ & $13.5 \mathrm{U}$ & $16.4 \mathrm{U}$ & $17.5 \mathrm{U}$ \\
Naphthalene & $19.0 \mathrm{~B}$ & $41.9 \mathrm{~B}$ & $13.5 \mathrm{U}$ & $23.7 \mathrm{~B}$ & $24.9 \mathrm{~B}$ \\
Acenaphthylene & $3.4 \mathrm{U}$ & $3.9 \mathrm{U}$ & $5.3 \mathrm{U}$ & $4.5 \mathrm{U}$ & $4.8 \mathrm{U}$ \\
Acenaphthene & $8.52 \mathrm{U}$ & $9.76 \mathrm{U}$ & $9.43 \mathrm{U}$ & $11.4 \mathrm{U}$ & $12.1 \mathrm{U}$ \\
Fluorene & $7.84 \mathrm{U}$ & $9.05 \mathrm{U}$ & $10.4 \mathrm{~B}$ & $10.5 \mathrm{U}$ & $11.2 \mathrm{U}$ \\
Phenanthrene & $16.4 \mathrm{U}$ & $18.8 \mathrm{U}$ & $18.6 \mathrm{U}$ & $21.9 \mathrm{U}$ & $23.3 \mathrm{U}$ \\
Anthracene & $13.8 \mathrm{U}$ & $15.9 \mathrm{U}$ & $16.3 \mathrm{U}$ & $18.4 \mathrm{U}$ & $19.6 \mathrm{U}$ \\
Fluoranthene & $19.0 \mathrm{U}$ & $21.8 \mathrm{U}$ & $38.9 \mathrm{U}$ & $25.4 \mathrm{U}$ & $27.1 \mathrm{U}$ \\
Pyrene & 29.1 & $19.7 \mathrm{U}$ & $33.2 \mathrm{U}$ & 42.9 & 38.4 \\
Benzo[a]anthracene & $5.5 \mathrm{U}$ & $6.3 \mathrm{U}$ & $7.91 \mathrm{U}$ & 8.21 & $7.83 \mathrm{U}$ \\
Chrysene & 11.5 & $12.3 \mathrm{U}$ & $16.5 \mathrm{U}$ & $14.2 \mathrm{U}$ & $15.2 \mathrm{U}$ \\
Benzo[b]fluoranthene & $6.98 \mathrm{U}$ & $8.04 \mathrm{U}$ & $11.9 \mathrm{U}$ & $9.32 \mathrm{U}$ & $9.95 \mathrm{U}$ \\
Benzo[k]fluoranthene & $9.20 \mathrm{U}$ & $10.6 \mathrm{U}$ & $12.1 \mathrm{U}$ & $12.3 \mathrm{U}$ & $13.1 \mathrm{U}$ \\
Benzo[a]pyrene & $7.84 \mathrm{U}$ & $9.05 \mathrm{U}$ & $10.8 \mathrm{U}$ & $10.5 \mathrm{U}$ & $11.2 \mathrm{U}$ \\
Indeno[123-cd]pyrene & $9.38 \mathrm{U}$ & $10.8 \mathrm{U}$ & $12.8 \mathrm{U}$ & $12.5 \mathrm{U}$ & $13.3 \mathrm{U}$ \\
Dibenzo[a,h]anthracene & $7.47 \mathrm{U}$ & $8.61 \mathrm{U}$ & $9.14 \mathrm{U}$ & $10.0 \mathrm{U}$ & $10.6 \mathrm{U}$ \\
Benzo[g,h,i]perylene & $6.54 \mathrm{U}$ & $7.54 \mathrm{U}$ & $10.2 \mathrm{U}$ & $8.79 \mathrm{U}$ & $9.32 \mathrm{U}$
\end{tabular}


Table G.8. (contd)

\begin{tabular}{lccccc} 
& \multicolumn{5}{c}{ Concentration $(\mu \mathrm{g} / \mathrm{kg}$ dry wt) } \\
\cline { 2 - 6 } Sediment Treatment & MDRS & MDRS & Nereis Bkgd. & Nereis Bkgd. & Nereis Bkgd. \\
Replicate & 4 & 5 & Tissue & Tissue & Tissue \\
Analytical Replicate & 3 & 1 & 1 & 2 & 3 \\
Wet Weight $(g)$ & 12.3 & 20.1 & 20.4 & 20.0 & 20.5 \\
Percent Dry Weight & 18.9 & 15.0 & 17.4 & 17.4 & 17.4 \\
Batch & 1 & 1 & 2 & 2 & 2 \\
\hline & & & & & \\
1,4-Dichlorobenzene & $17.3 \mathrm{U}$ & $13.3 \mathrm{U}$ & $10.5 \mathrm{U}$ & $10.7 \mathrm{U}$ & $10.5 \mathrm{U}$ \\
Naphthalene & $23.6 \mathrm{~B}$ & $19.8 \mathrm{~B}$ & $10.5 \mathrm{U}$ & $10.7 \mathrm{U}$ & $10.5 \mathrm{U}$ \\
Acenaphthylene & $4.8 \mathrm{U}$ & $3.7 \mathrm{U}$ & $4.1 \mathrm{U}$ & $4.2 \mathrm{U}$ & $4.1 \mathrm{U}$ \\
Acenaphthene & $12.0 \mathrm{U}$ & $9.22 \mathrm{U}$ & $7.38 \mathrm{U}$ & $7.49 \mathrm{U}$ & $7.38 \mathrm{U}$ \\
Fluorene & $11.1 \mathrm{U}$ & $8.48 \mathrm{U}$ & $10.7 \mathrm{~B}$ & $7.15 \mathrm{U}$ & $6.97 \mathrm{U}$ \\
Phenanthrene & $23.0 \mathrm{U}$ & $17.8 \mathrm{U}$ & $14.5 \mathrm{U}$ & $14.8 \mathrm{U}$ & $14.5 \mathrm{U}$ \\
Anthracene & $19.4 \mathrm{U}$ & $15.0 \mathrm{U}$ & $12.6 \mathrm{U}$ & $12.9 \mathrm{U}$ & $12.6 \mathrm{U}$ \\
Fluoranthene & $26.7 \mathrm{U}$ & $20.6 \mathrm{U}$ & $30.3 \mathrm{U}$ & $30.9 \mathrm{U}$ & $30.3 \mathrm{U}$ \\
Pyrene & 32.6 & 21.3 & $25.8 \mathrm{U}$ & $26.3 \mathrm{U}$ & $25.8 \mathrm{U}$ \\
Benzo[a]anthracene & 7.78 & 7.01 & $10.3 \mathrm{~B}$ & $8.82 \mathrm{~B}$ & $11.3 \mathrm{~B}$ \\
Chrysene & $15.0 \mathrm{U}$ & $11.6 \mathrm{U}$ & $12.8 \mathrm{U}$ & $13.1 \mathrm{U}$ & $12.8 \mathrm{U}$ \\
Benzo[b]fluoranthene & $9.8 \mathrm{U}$ & $7.55 \mathrm{U}$ & $9.28 \mathrm{U}$ & $9.45 \mathrm{U}$ & $9.28 \mathrm{U}$ \\
Benzo[k]fluoranthene & $12.9 \mathrm{U}$ & $10.0 \mathrm{U}$ & $9.45 \mathrm{U}$ & $9.63 \mathrm{U}$ & $9.45 \mathrm{U}$ \\
Benzo[a]pyrene & $11.1 \mathrm{U}$ & $8.48 \mathrm{U}$ & $8.41 \mathrm{U}$ & $8.59 \mathrm{U}$ & $8.41 \mathrm{U}$ \\
Indeno[123-cd]pyrene & $13.2 \mathrm{U}$ & $10.2 \mathrm{U}$ & $10.0 \mathrm{U}$ & $10.1 \mathrm{U}$ & $9.97 \mathrm{U}$ \\
Dibenzo[a,h]anthracene & $10.5 \mathrm{U}$ & $8.08 \mathrm{U}$ & $7.15 \mathrm{U}$ & $7.26 \mathrm{U}$ & $7.15 \mathrm{U}$ \\
Benzo[g,h,i]perylene & $9.21 \mathrm{U}$ & $7.08 \mathrm{U}$ & $7.90 \mathrm{U}$ & $8.07 \mathrm{U}$ & $7.90 \mathrm{U}$
\end{tabular}

(a) U Undetected at or above given concentration.

(b) B Analyte detected in sample is $<5 x$ blank value.

(c) Ion ratio out or confirmation ion not detected.

(d) MDRS Mud dump reference site. 
Table G.9. Quality Control Data for Polynuclear Aromatic Hydrocarbon (PAH) Analysis of $N$. virens Tissue (Wet Weight)

Matrix Spike Resuits

\begin{tabular}{|c|c|c|c|c|c|c|c|}
\hline \multirow[b]{2}{*}{$\begin{array}{l}\text { Sediment Treatment } \\
\text { Replicate }\end{array}$} & \multirow[b]{2}{*}{ Blank } & & \multicolumn{4}{|c|}{ Concentration $(\mu \mathrm{g} / \mathrm{kg}$ wet $w t)$} & \multirow{2}{*}{ Percen } \\
\hline & & & $\begin{array}{c}\operatorname{SR~COMP}^{(a)} \\
3\end{array}$ & $\begin{array}{l}\text { SR COMP } \\
\text { (MS) }\end{array}$ & \multicolumn{2}{|c|}{ Concentration } & \\
\hline Analytical Replicate & 1 & 1 & 1 & 1 & Spiked & Recovered & Recover \\
\hline Wet Weight (g) & 20.0 & 18.0 & 13.2 & 13.1 & & & \\
\hline Batch & 1 & 2 & 1 & 1 & & & \\
\hline 1,4-Dichlorobenzene & $2.00 \mathrm{U}^{(\mathrm{b})}$ & $2.09 \mathrm{U}$ & $3.03 \mathrm{U}$ & $3.05 \mathrm{U}$ & $N S^{(c)}$ & $N A^{(d)}$ & NA \\
\hline Naphthalene & 2.34 & $2.09 \mathrm{U}$ & $4.51 \mathrm{~B}^{(\mathrm{e})}$ & 49.0 & 38.1 & 44.5 & 117 \\
\hline Acenaphthylene & $0.55 \mathrm{U}$ & $0.81 \mathrm{U}$ & $0.83 \mathrm{U}$ & 41.9 & 38.1 & 41.9 & 110 \\
\hline Acenaphthene & $1.39 \mathrm{U}$ & $1.46 U$ & $2.10 \mathrm{U}$ & 44.3 & 38.1 & 44.3 & 116 \\
\hline Fluorene & $1.28 \mathrm{U}$ & 1.72 & $1.94 \mathrm{U}$ & 47.4 & 38.1 & 47.4 & $124^{(n)}$ \\
\hline Phenanthrene & $2.67 \mathrm{U}$ & $2.87 \mathrm{U}$ & $4.04 \mathrm{U}$ & 43.4 & 38.1 & 43.4 & 114 \\
\hline Anthracene & $2.25 \mathrm{U}$ & $2.51 \mathrm{U}$ & $3.40 \mathrm{U}$ & 41.6 & 38.1 & 41.6 & 109 \\
\hline Fluoranthene & $3.10 \mathrm{U}$ & $6.01 \mathrm{U}$ & 17.0 & 68.5 & 38.1 & 51.6 & $135^{(f)}$ \\
\hline Pyrene & $2.79 \mathrm{U}$ & $5.12 \mathrm{U}$ & 25.6 & 80.5 & 38.1 & 55.0 & $144^{(f)}$ \\
\hline Benzo[a]anthracene & $0.90 \mathrm{U}$ & 1.59 & 1.70 & 48.5 & 38.1 & 46.8 & $123^{(f)}$ \\
\hline Chrysene & $1.74 \mathrm{U}$ & $2.54 \mathrm{U}$ & 4.27 & 48.2 & 38.1 & 43.9 & 115 \\
\hline Benzo[b]fluoranthene & $1.14 \mathrm{U}$ & $1.84 \mathrm{U}$ & $1.72 \mathrm{U}$ & 44.6 & 38.1 & 44.6 & 117 \\
\hline Benzo[k]fluoranthene & $1.50 \mathrm{U}$ & $1.87 \mathrm{U}$ & $2.27 \mathrm{U}$ & 42.2 & 38.1 & 42.2 & 111 \\
\hline Benzo[a]pyrene & $1.28 \mathrm{U}$ & $1.67 \mathrm{U}$ & $1.94 \mathrm{U}$ & 43.4 & 38.1 & 43.4 & 114 \\
\hline Indeno[123-cd]pyrene & $1.53 \mathrm{U}$ & $1.97 \mathrm{U}$ & $2.31 \mathrm{U}$ & 42.0 & 38.1 & 42.0 & 110 \\
\hline Dibenzo[a,h]anthracene & $1.22 \mathrm{U}$ & $1.41 \mathrm{U}$ & $1.85 \mathrm{U}$ & 41.6 & 38.1 & 41.6 & 109 \\
\hline Benzo[g,h,i]perylene & $1.07 \mathrm{U}$ & $1.57 \mathrm{U}$ & $1.62 \mathrm{U}$ & 40.7 & 38.1 & 40.7 & 107 \\
\hline \multicolumn{8}{|l|}{ Surrogate Recoveries (\%) } \\
\hline d4 1,4-Dichlorobenzene & 53 & 55 & 64 & 65 & NA & NA & NA \\
\hline d8 Naphthalene & 66 & 61 & 72 & 76 & NA & NA & NA \\
\hline d10 Acenaphthene & 78 & 65 & 90 & 93 & NA & NA & NA \\
\hline d12 Chrysene & 99 & 76 & 84 & 86 & NA & NA & NA \\
\hline d14 Dibenzo[a, h]anthracene & 79 & 88 & 118 & 128 & NA & NA & NA \\
\hline
\end{tabular}


Table G.9. (contd)

Matrix Spike Results

Sediment Treatment

Replicate

Analytical Replicate

Wet Weight (g)

Batch

1,4-Dichlorobenzene

Naphthalene

Acenaphthylene

Acenaphthene

Fluorene

Phenanthrene

Anthracene

Fluoranthene

Pyrene

Benzo[a]anthracene

Chrysene

Benzo[b]fluoranthene

Benzo[k]fluoranthene

Benzo[a]pyrene

Indeno[123-cd]pyrene

Dibenzo[a,h]anthracene

Benzo[g,h,i]perylene

SH CON

Concentration ( $\mu \mathrm{g} / \mathrm{kg}$ wet $\mathrm{wt}$ )

$\begin{array}{cccc}\text { COMP }^{(a)} & \mathrm{SHCOMP}(\mathrm{MS}) & & \\ 1 & & \text { Concentration } & \text { Percent } \\ 1 & 1 & \text { Spiked Recovered } & \text { Recovery } \\ 13.1 & 13.6 & & \\ 2 & 2 & & \\ & & & \end{array}$

$\begin{array}{llccc}2.87 \mathrm{U} & 2.76 \mathrm{U} & \mathrm{NS} & \mathrm{NA} & \text { NA } \\ 2.87 \mathrm{U} & 47.1 & 38.5 & 47.1 & 122{ }^{(f)} \\ 1.52 \mathrm{~g}) & 36.0 & 38.5 & 34.5 & 90 \\ 4.84 & 39.7 & 38.5 & 34.8 & 90 \\ 2.56 \mathrm{~B} & 38.4 & 38.5 & 35.8 & 93 \\ 3.94 \mathrm{U} & 34.4 & 38.5 & 34.4 & 89 \\ 3.45 \mathrm{U} & 41.2 & 38.5 & 41.2 & 107 \\ 47.6 & 75.6 & 38.5 & 28.0 & 73 \\ 62.2 & 86.8 & 38.5 & 24.6 & 64 \\ 1.68 \mathrm{U} & 44.3 & 38.5 & 44.3 & 115 \\ 12.8 & 46.8 & 38.5 & 34.0 & 88 \\ 4.1 \text { (g) }^{\text {(g) }} & 47.2 & 38.5 & 43.1 & 112 \\ 2.96 & 43.8 & 38.5 & 40.9 & 106 \\ 2.30 \mathrm{U} & 40.4 & 38.5 & 40.4 & 105 \\ 2.71 \mathrm{U} & 34.8 & 38.5 & 34.8 & 90 \\ 1.94 \mathrm{U} & 33.0 & 38.5 & 33.0 & 86 \\ 2.16 \mathrm{U} & 30.0 & 38.5 & 30.0 & 78\end{array}$

Surrogate Recoveries (\%)

d4 1,4-Dichlorobenzene

d8 Naphthalene

d10 Acenaphthene

d12 Chrysene

d14 Dibenzo[a,h]anthracene

$\begin{array}{rr}64 & 50 \\ 78 & 63 \\ 88 & 73 \\ 89 & 81 \\ 108 & 101\end{array}$

$\begin{array}{lll}\text { NA } & \text { NA } & \text { NA } \\ \text { NA } & \text { NA } & \text { NA } \\ \text { NA } & \text { NA } & \text { NA } \\ \text { NA } & \text { NA } & \text { NA } \\ \text { NA } & \text { NA } & \text { NA }\end{array}$


Table G.9. (contd)

Analytical Replicates

\begin{tabular}{|c|c|c|c|c|}
\hline \multirow[b]{2}{*}{ Sediment Treatment } & \multicolumn{3}{|c|}{ Concentration ( $\mu \mathrm{g} / \mathrm{kg}$ wet $w t)$} & \multirow[b]{3}{*}{ RSD } \\
\hline & MDRS $^{(h)}$ & MDRS & MDRS & \\
\hline Replicate & 4 & 4 & 4 & \\
\hline Analytical Replicate & 1 & 2 & 3 & $(\%)$ \\
\hline Wet Weight (g) & 12.9 & 12.1 & 12.3 & \\
\hline Batch & 1 & 1 & 1 & \\
\hline 1,4-Dichlorobenzene & $3.10 \mathrm{U}$ & $3.30 \mathrm{U}$ & $3.26 U$ & NA \\
\hline Naphthalene & $4.48 \mathrm{~B}$ & $4.70 \mathrm{~B}$ & $4.46 \mathrm{~B}$ & 3 \\
\hline Acenaphthylene & $0.85 \mathrm{U}$ & $0.91 \mathrm{U}$ & $0.90 \mathrm{U}$ & NA \\
\hline Acenaphthene & $2.15 \mathrm{U}$ & $2.29 \mathrm{U}$ & $2.27 \mathrm{U}$ & NA \\
\hline Fluorene & $1.98 \mathrm{U}$ & $2.11 \mathrm{U}$ & $2.09 \mathrm{U}$ & NA \\
\hline Phenanthrene & $4.13 U$ & $4.40 \mathrm{U}$ & $4.35 \mathrm{U}$ & NA \\
\hline Anthracene & $3.48 \mathrm{U}$ & $3.71 \mathrm{U}$ & $3.67 \mathrm{U}$ & NA \\
\hline Fluoranthene & $4.80 \mathrm{U}$ & $5.11 \mathrm{U}$ & $5.05 \mathrm{U}$ & NA \\
\hline Pyrene & 8.10 & 7.26 & 6.16 & 14 \\
\hline Benzo[a]anthracene & 1.55 & $1.48 U$ & 1.47 & NA \\
\hline Chrysene & $2.69 \mathrm{U}$ & $2.87 \mathrm{U}$ & $2.84 \mathrm{U}$ & NA \\
\hline Benzo[b]fluoranthene & $1.76 \mathrm{U}$ & $1.88 \mathrm{U}$ & $1.86 \mathrm{U}$ & NA \\
\hline Benzo[k]fluoranthene & $2.32 U$ & $2.47 \mathrm{U}$ & $2.44 \mathrm{U}$ & NA \\
\hline Benzo[a]pyrene & $1.98 \mathrm{U}$ & $2.11 \mathrm{U}$ & $2.09 \mathrm{U}$ & NA \\
\hline Indeno[123-cd]pyrene & $2.37 \mathrm{U}$ & $2.52 \mathrm{U}$ & $2.49 \mathrm{U}$ & NA \\
\hline Dibenzo[a,h]anthracene & $1.89 \mathrm{U}$ & $2.01 \mathrm{U}$ & $1.99 \mathrm{U}$ & NA \\
\hline Benzo[g,h,i]perylene & $1.66 \mathrm{U}$ & $1.76 \mathrm{U}$ & $1.74 \mathrm{U}$ & NA \\
\hline \multicolumn{5}{|l|}{ Surrogate Recoveries (\%) } \\
\hline d4 1,4-Dichlorobenzene & 88 & 75 & 78 & NA \\
\hline d8 Naphthalene & 81 & 72 & 80 & NA \\
\hline d10 Acenaphthene & 91 & 90 & 95 & NA \\
\hline d12 Chrysene & 77 & 85 & 90 & NA \\
\hline d14 Dibenzo[a,h]anthracene & 125 & 123 & 113 & NA \\
\hline
\end{tabular}


Table G.9. (contd)

Analytical Replicates

Sediment Treatment

Replicate

Analytical Replicate

Wet Weight (g)

Batch

1,4-Dichlorobenzene

Naphthalene

Acenaphthylene

Acenaphthene

Fluorene

Phenanthrene

Anthracene

Fluoranthene

Pyrene

Benzo[a]anthracene

Chrysene

Benzo[b]fluoranthene

Benzo[k]fluoranthene

Benzo[a]pyrene

Indeno[123-cd]pyrene

Dibenzo[a,h]anthracene

Benzo[g,h,i]perylene

Surrogate Recoveries (\%)

d4 1,4-Dichlorobenzene

d8 Naphthalene

d10 Acenaphthene

d12 Chrysene

d14 Dibenzo[a,h]anthracene

Nere

Concentration ( $\mu \mathrm{g} / \mathrm{kg}$ wet $\omega t)$

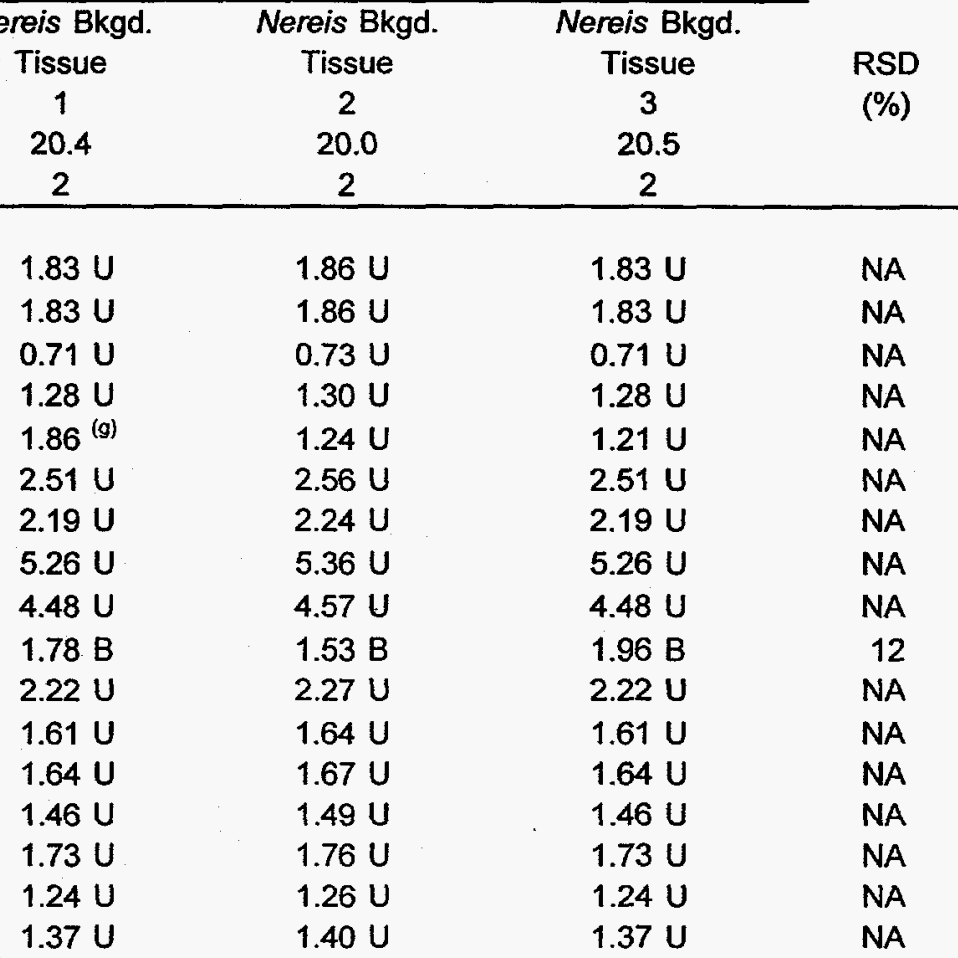

$\begin{array}{rrrr}55 & 45 & 63 & \text { NA } \\ 69 & 57 & 77 & \text { NA } \\ 83 & 68 & 86 & \text { NA } \\ 90 & 75 & 90 & \text { NA } \\ 112 & 91 & 111 & \text { NA }\end{array}$

(a) Sample randomly selected for use as a quality control sample in analytical batch.

(b) U Undetected at or above given concentration.

(c) NS Not spiked.

(d) NA Not applicable.

(e) B Analyte detected in the sample is $>5$ times the blank value.

(f) Outside quality control criteria (50-120\%) for spike recovery.

(g) Ion ratio out or confirmation ion not detected.

(h) MDRS Mud Dump Reference Site. 
Table G.10. Lipids in Tissue of $N$. virens

\begin{tabular}{lccc} 
Sample ID & $\begin{array}{c}\text { \% Dry } \\
\text { Weight }\end{array}$ & $\begin{array}{c}\text { \% Lipid } \\
\text { (wet wt) }\end{array}$ & $\begin{array}{c}\text { \% Lipid } \\
\text { (dry wt) }\end{array}$ \\
\hline Nereis Bkgd. Tissue & 14.37 & 1.20 & 8.35 \\
Nereis Bkgd. Tissue & 14.37 & 0.99 & 6.89 \\
Nereis Bkgd. Tissue & 14.37 & 1.19 & 8.28
\end{tabular}

